JOSÉ HORACIO GRAU JIPOULOU

RELAÇÕES FILOGENÉTICAS ENTRE OS GÊNEROS DE GEOPLANINAE (PLATYHELMINTHES, TRICLADIDA) INFERIDAS DE CARACTERES MORFOLÓGICOS

\author{
PHYLOGENETIC RELATIONSHIPS OF THE \\ GEOPLANINAE GENERA (PLATYHELMINTHES, \\ TRICLADIDA) AS INFERRED FROM MORPHOLOGICAL \\ CHARACTERS
}

São Paulo

2010 
JOSÉ HORACIO GRAU JIPOULOU

\title{
RELAÇÕES FILOGENÉTICAS ENTRE OS GÊNEROS DE GEOPLANINAE (PLATYHELMINTHES, TRICLADIDA) INFERIDAS DE CARACTERES MORFOLÓGICOS
}

\author{
PHYLOGENETIC RELATIONSHIPS OF THE \\ GEOPLANINAE GENERA (PLATYHELMINTHES, \\ TRICLADIDA) AS INFERRED FROM MORPHOLOGICAL \\ CHARACTERS
}

Dissertação apresentada ao Instituto de Biociências da Universidade de São Paulo, para a obtenção de Título de Mestre em Ciências, na Área de Zoologia.

Orientador:

Dr. Fernando Jesús Carbayo Baz

São Paulo

2010 
Ficha Catalográfica

\section{G 774r}

Grau, José Horacio

Relações Filogenéticas Entre os Gêneros de Geoplaninae (Platyhelminthes, Tricladida) Inferidas de Caracteres Morfológicos

José Horacio Grau. - São Paulo: J.H.G., 2010.

156 pp.: il.

Dissertação (Mestrado) - Instituto de Biociências da Universidade de São Paulo. Departamento de Zoologia, 2010.

1. Platyhelminthes 2. Planárias. I. Universidade de São Paulo. Instituto de Biociências. Departamento de Zoologia.

\section{Comissão Julgadora:}




\section{Dedicatória}

à Camilla e ao Jan Jan. 


\section{Agradecimentos}

Ao CNPq pela bolsa de Mestrado. Este projeto foi parcialmente financiado pela FAPESP (proc. 07/03890-6) e pela Fundación BBVA.

Ao Fernando Marques e ao pessoal do laboratório de helmintologia evolutiva pelo espaço, materiais, confiança e a amizade.

À Eudóxia Maria Froehlich, pela confiança e a tempo dedicado a conversas muito inspiradoras.

Ao Antonio Marques, Coordenador da Pós-Graduação em Zoologia, pelos conselhos e por responder minhas 1001 perguntas.

Ao Laboratório de Biodiversidade de planárias da $\mathrm{EACH}$, muito obrigado gente pela valiosa amizade.

Ao Museum Für Naturkunde Berlin, na Alemanha em especial ao curador de Vermes, Dr. Birger Neuhaus por ceder o espaço, ajuda e a amizade nos meus tempos em Berlin.

Ao Natuhistorisches Museum Wien, ao curador e diretor do departamento de invertebrados Dr. Helmut Sattmann, e ao seu preparador Stefan Szeiler pela luxuosa acolhida nas duas visitas científicas a Viena.

Ao Zoological Museum of the University of Amsterdam, e ao professor Ronald Sluys pelas visitas e pelo constante apoio e co-orientação neste trabalho.

Ao Tom Artois, pela boa acolhida no simpósio internacional de turbelários na Bélgica.

A meus amigos de Berlin, Öle e Cristian, e em especial a Boris Wolter. A meu amigo Thomas Göttert, pelas conversas e pelos bons conselhos nos momentos difíceis.

Ao meu irmão Javier pela ajuda ao fotografar lâminas de planárias. Gracias.

Ao meu orientador e amigo Fernando Carbayo Baz pela amizade, confiança e pela excelente orientação neste trabalho. A Gládis Maria, esposa do meu orientador. Sem vocês, isto não teria acontecido.

Ao meus pais, em especial as orações da minha mãe que me realmente parece que fazem uma diferença importante. A meu avô, Juan Grau que em paz descanse, por cultivar o espírito científico em mim desde criança.

À minha mulher Camilla Elle, e nosso filho Jan Paulo, por ter a valentia de deixar a comodidade na Alemanha pra vir comigo conquistar São Paulo.

Aos meus amigos da zoo, e do IB .... caras, sem vocês não teria agüentado.

Obrigado mesmo ! 


\section{Resumo}

Este trabalho consiste em uma caracterização morfológica das espécies-tipo da maioria dos gêneros que compõem a subfamília Geoplaninae, e quatro espécies destinadas a servir como grupos externos (Pelmatoplanini, Anzoplanini, Caenoplanini, Bipaliinae). A estudo morfológico das espécies resultou em 69 caracteres morfológicos que foram inseridos em uma matriz de dados e preparados para análise filogenética. Quinze espécies adicionais de outros gêneros de Geoplaninae também foram incluídos na análise. Os resultados corroboram o monofiletismo da subfamília Geoplaninae. De acordo com a hipótese de Meixner, o clado formado pelos gêneros Enterosyringa e Xerapoa, que compartilha características morfológicas com espécies do grupo externo, é o grupo de irmãos de todas as demais espécies de Geoplaninae. Descobrimos que as características anatômicas do aparelho copulador, como a presença e o tipo de papila peniana mostraram possuir muitas reversões e não se mostraram filogeneticamente informativas. Caracteres do sistema muscular podem ser usados de forma mais efetiva para a definição de grupos taxonômicos dentro do Geoplaninae e como indicadores de suas relações evolutivas. Nenhum dos aspectos diagnóstico atuais de da Geoplaninae correspondeu a caracteres autopomórficos em nossa análise. Nossos resultados sugerem que vários gêneros de Geoplaninae representam grupos não naturais, i.e., Geoplana e Notogynaphallia, com alguns caracteres diagnósticos sendo homoplásicos. 


\begin{abstract}
This work consists of a morphological characterization of the type species of most of the genera that compose Geoplaninae, and four species intended to serve as outgroups (Pelmatoplanini, Anzoplanini, Caenoplanini, Bipaliinae). The morphological study of the species resulted in 69 morphological characters that were entered into a data matrix and prepared for phylogenetic analysis. Fifteen additional species from other Geoplaninae genera were also included in the analysis. The results corroborate the monophyletic status of the subfamily Geoplaninae. According with Meixner's hypothesis, the clade formed by Enterosyringa and Xerapoa species, sharing morphological characteristics with outgroup species, is the sister group of all other Geoplaninae species. We found that anatomical features of the copulatory apparatus, such as the presence and type of penis papilla showed many reversions and were not phylogenetically informative. Characters of the muscular system can be used much better for defining taxonomic groups within the Geoplaninae and as indicators of their evolutionary relationships. None of the present diagnostic features of the Geoplaninae formed autapomorphic characters in our analysis. Our results suggest that several genera of Geoplaninae represent unnatural groups, viz., Geoplana and Notogynaphallia, with some diagnostic characters being homoplasic.
\end{abstract}




\section{SUMÁRIO}

Capítulo 1: Panorama geral.

1

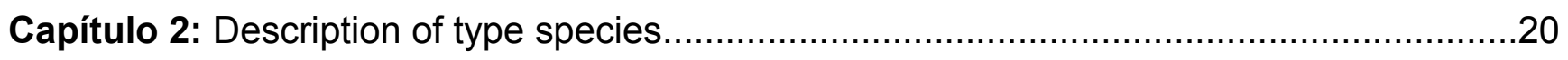

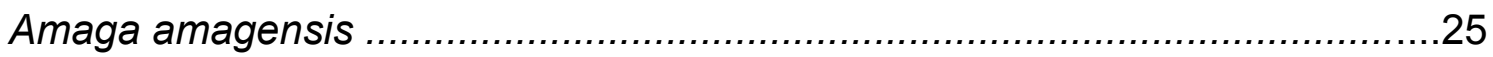

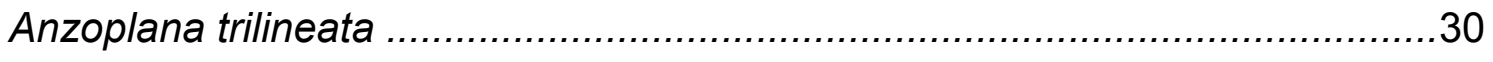

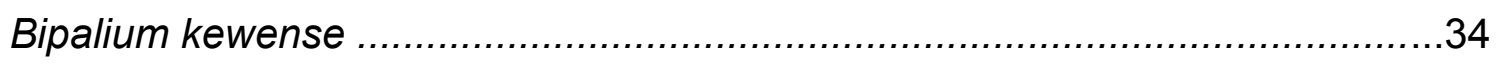

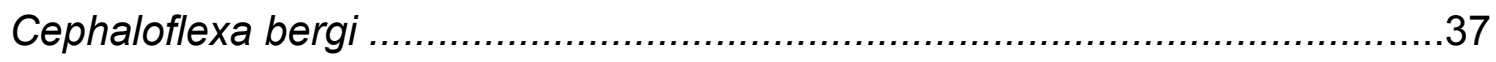

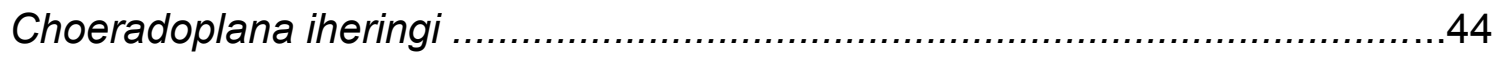

Dolichoplana carvalhoi ................................................................. 50

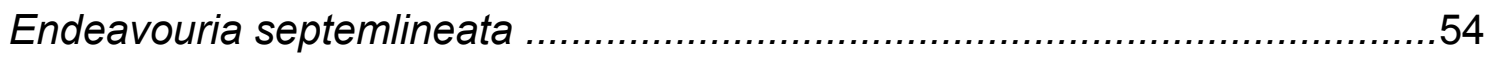

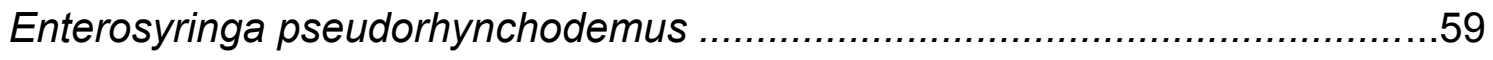

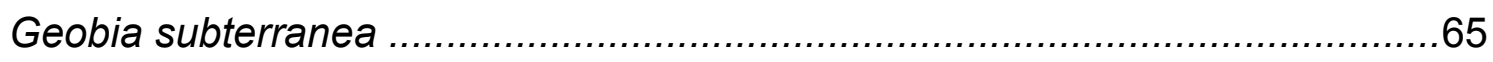

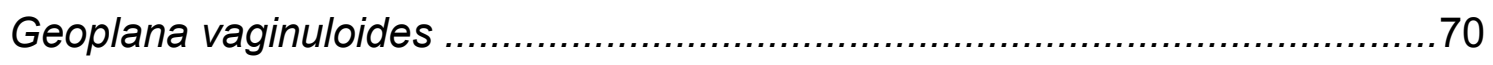

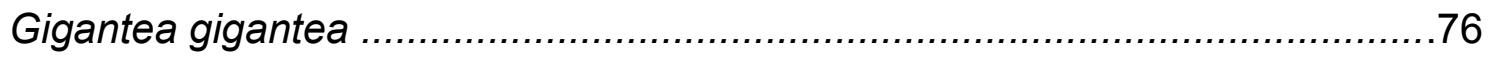

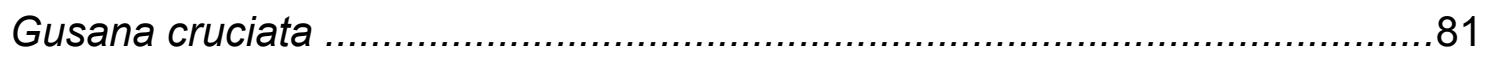

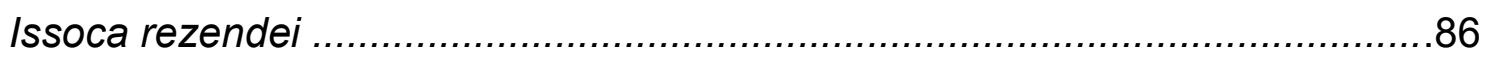

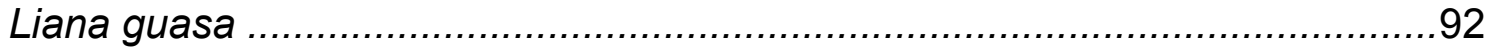

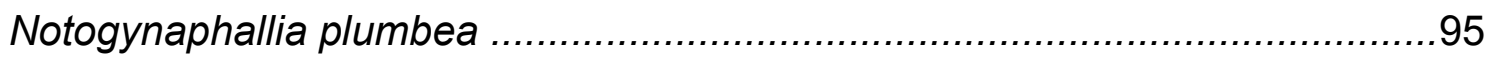

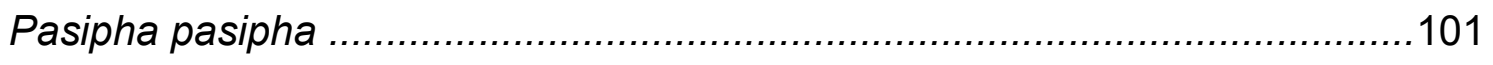

Pelmatoplana moluccana .........................................................................107

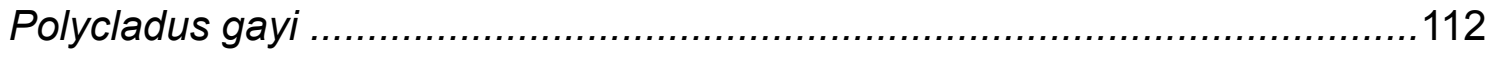

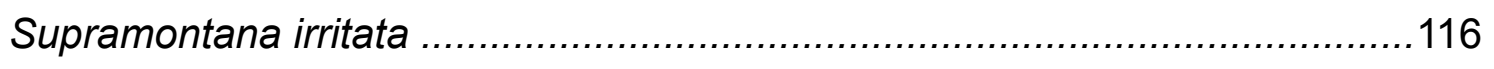

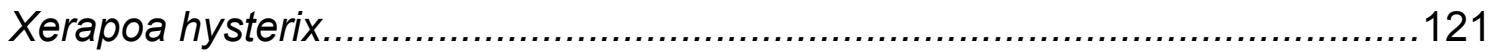

Capítulo 3: Towards a phylogenetic classification

of the Geoplaninid land planarians:

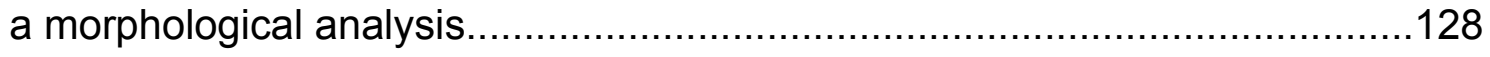

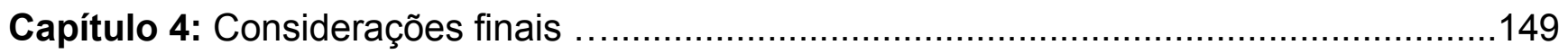



Capítulo 1

Panorama geral

1 


\subsection{Geoplaninae: biologia e morfologia}

As planárias terrestres são vermes achatados, de aparência frágil que pertencem ao ecossistema do solo. A grande maioria das planárias terrestres é predadora de outros invertebrados. Elas procuram, atacam e capturam suas presas, às vezes de maior tamanho que elas, por força física e pela ação adesiva e digestiva do seu muco (Ogren, 1995). As planárias terrestres alimentam-se de caramujos, lesmas, minhocas, artrópodes e até outras planárias. Algumas espécies de planárias têm-se convertido em pragas. A planária neozelandesa Artioposthia triangulata (Dendy), introduzida inadvertidamente no Reino Unido, dizimou localmente a fauna de minhocas nativa (Alford,1998). A planária espécie Platydemus manokwari foi introduzida deliberadamente na ilha Guam e nas Filipinas para o controle biológico, sem sucesso, do caramujo gigante africano Achatina fulica (Kawakatsu et al, 1992; Sugiura et al, 2006) o que demostra o sucesso das planarias terrestres como predadoras.

As planárias não possuem mecanismos de retenção de água e são muito sensíveis às variações de umidade do ambiente (Kawaguti, 1932), sendo mais ativas durante a noite, e ficando escondidas durante o dia sob a serapilheira, troncos, galhos e pedras.

Em virtude de suas restrições biológicas e ecológicas, algumas espécies de planárias terrestres têm sido propostas e usadas como indicadores do estado de conservação de seus habitats (Carbayo et al., 2002; Sluys, 1999). Como são animais relativamente imóveis e de habitat muito específico, seus padrões filogeográficos podem permitir uma precisa inferência da delimitação de zonas biogeográficas (Schauble \& Moritz, 2001; Garrick et al., 2004; Sunnucks et al., 2006).

Assim como outros membros do filo Platyhelminthes, as planárias têm simetria bilateral, polos antero-posterior e cefalização, com os órgãos sensoriais localizados na região anterior ou cefálica. O ventre está em contato com o substrato e é oposto à superfície dorsal. Seu corpo varia de tamanho entre 10 e 100 mm; há registro de uma espécie gigantesca da subfamília Bipaliinae com um comprimento de até $100 \mathrm{~cm}$ (Kawakatsu et al., 1982; Kawakatsu et al., 2001).

As planárias terrestres apresentam uma grande variedade de formas e cores. O corpo pode ser fino ou largo, plano ou sub-cilíndrico. As extremidades anterior e posterior são geralmente mais finas que o resto do corpo. Em vista dorsal, a forma do corpo pode ser entre 
linear (bordos do corpo paralelos) ou lanceolada (os bordos são curvos e convergentes nas extremidades).

Em algumas espécies a ponta anterior tem uma forma diferenciada do resto do corpo. Ela pode ser levantada e enrolada em direção ao dorso (Choeradoplana, Xerapoa, Enterosyringa) ou na forma de uma colher invertida (Issoca). A cabeça também pode apresentar papilas sensoriais laterais (Xerapoa). As espécies da subfamília Bipaliinae, oriental, mostram cabeça com expansões laterais formando uma meia-lua muito característica; no resto das Geoplanidae as regiões anterior são mais finas que o corpo.

A superfície do corpo das planarias está coberta por uma película de muco, que thes dá uma aparência brilhante. Algumas espécies são vivamente coloridas, com diversos padrões de distribuição das cores, tais como estrias e faixas longitudinais ou transversais, como também machas irregulares de cores muito chamativas e vivas, como azul e laranja. Outras espécies são monocromáticas, com cor geralmente preta, cinza, marrom ou verde. Em todas elas o ventre tem normalmente uma cor mais apagada, com tons predominantemente esbranquiçados; em algumas espécies é de cor limão, avermelhada, esverdeada ou acinzentada.

O olho de uma planária terrestre está composto por um cálice de retina de 20-50 $\mu \mathrm{m}$ de diâmetro. Os olhos podem estar presentes como um único par na parte anterior do corpo, como na família Rhynchodemidae, enquanto outras subfamílias como Geoplaninae e Bipaliinae apresentam numerosos olhos na extremidade anterior, e na superfície dorsal, e em algumas espécies atingindo até a extremidade posterior. É comum que os olhos estejam rodeados por um anel circular despigmentado chamado halo.

Muitas espécies têm um bordo sensorial que contorna ventralmente a região anterior e, às vezes, este se estende ao longo do corpo. Ao longo deste bordo existem muitas aberturas aferentes. Estas aberturas são invaginações epidérmicas de 15-40 $\mu \mathrm{m}$ de profundidade, distribuídas em linhas simples ou raramente em séries de 4-8 linhas, dentro das quais existem estações quimo-receptores (Fernandes et al, 2001).

A maior parte do ventre corresponde à sola rastrejadora, que está composta por epiderme ciliada. Uma série de músculos causam ondas de movimento no corpo, dando uma aparência de deslizamento elegante ao se locomover o animal. Os cílios também auxiliam na 
locomoção. A sola torna-se mais estreita em direção às pontas do corpo e desaparece antes de atingir as extremidades. A boca e a abertura genital ou gonóporo também são encontrados na superfície ventral; ambos ocorrem a maioria das vezes na segunda metade do corpo.

Ao longo de praticamente toda a superfície da epiderme existem aberturas de glândulas unicelulares, classificadas como acidofílicas ou basofílicas, de acordo com a sua acidez, ou amorfa ou granular, de acordo com o aspecto da sua secreção. Frequentemente há secreção de diferentes tipos numa mesma região do corpo. Em algumas espécies as glândulas epidérmicas podem-se concentrar nas margens do corpo e formar um bordo glandular.

Na região cefálica podem ocorrer diferenciações e concentrações glandulares, constituindo uma zona glandular. Juntamente com estas diferenciações glandulares podem ocorrer especializações da musculatura subepidérmica longitudinal ventral; o conjunto é chamado de órgão músculo-glandular.

As planárias terrestres têm principalmente dois sistemas musculares, o sistema subepidérmico ou cutâneo e o sistema mesenquimático ou parenquimático. A musculatura subepidérmica pode ser bipartida ou tripartida, de acordo com o número de camadas, duas ou três, respectivamente. Musculatura bipartida está composta de uma camada mais externa com fibras circulares ou circulo-helicoidais seguido por uma camada muscular longitudinal. A musculatura tripartida está composta por uma camada externa circular seguida de uma camada de dupla diagonal, com as fibras decussadas, e uma camada longitudinal. A formação de feixes de fibras, bem como a relação espessura desta última camada (longitudinal) são importantes para diferenciar as tribos e as subfamílias da família Geoplanidae.

O sistema muscular mesenquimático (Figura 1) varia mais na composição e disposição que o sistema muscular subepidérmico. No sistema muscular mesenquimático muitas fibras musculares estão dispersas no interior do mesênquima, mas algumas reúnemse formando camadas. É mais comum encontrar uma camada doble diagonal embaixo do plexo nervoso sub-epidérmico dorsal, uma camada supra-intestinal e uma camada de subuma intestinal, ambas com as fibras geralmente em disposição transversal. Em algumas espécies existe uma quarta camada, também transversal, chamada camada subneural; 
localizada entre o plexo nervoso subepidérmico ventral e o sistema nervoso central. Assim como no sistema subepidérmica muscular, o sistema mesenquimático muscular pode apresentar especializações na região cefálica.

\section{Figura 1}

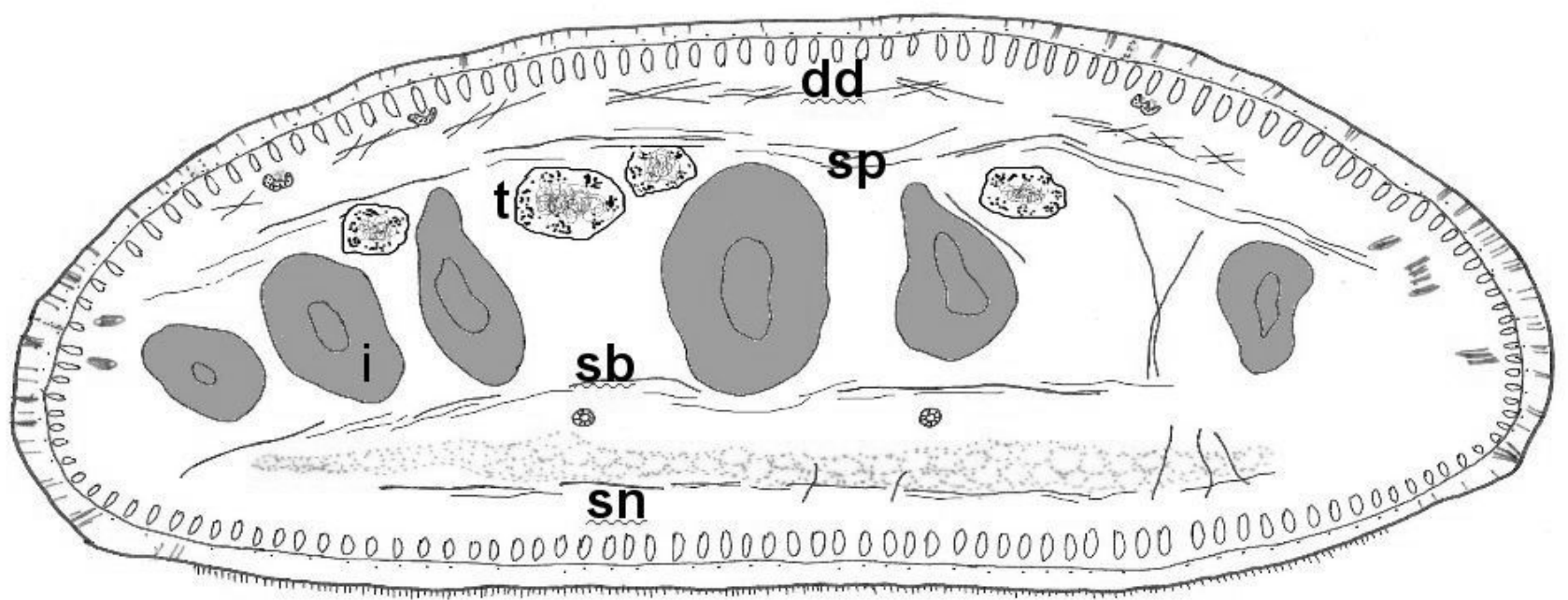

Figura 1. Desenho de corte transversal de um Geoplaninae típico mostrando as camadas de musculatura mesenquimática. Abreviações: dd: camada muscular doble diagonal dorsal, i: intestino; sb: camada muscular sub-intestinal; sn: camada muscular sub-neural; sp: camada muscular supraintestinal.

Todas as planárias possuem um sistema digestivo fechado composto por três ramos intestinais ramificados, um anterior e dois posteriores. A boca está presente como um pequeno poro ventral, geralmente localizado no início da metade posterior do corpo. Ele se comunica diretamente com a bolsa faríngea, que abriga uma faringe muscular orientada para a parte traseira do corpo. Durante a alimentação a faringe é projetada através da abertura da boca.

A faringe é uma estrutura semelhante a um tubo com duas camadas musculares, uma camada muscular externa e outra interna. Ambas as camadas são compostas de fibras musculares longitudinais e circulares; a disposição das camadas musculares internas e externas na faringe parece ser independente uma da outra. O mesênquima da faringe 
contém grande quantidade de glândulas e secreções e funciona como uma estrutura mecânica e química durante a alimentação. Às vezes a faringe pode apresentar um esôfago que comunica a luz da faringe com o intestino; é um prolongamento da parede interna da faringe.

A faringe recebe nomes diferentes dependendo do deslocamento da inserção dorsal da faringe. A faringe cilíndrica tem a inserção dorsal ao nível da à inserção ventral (Figura 2 A). Quando a faringe tem a inserção dorsal deslocada posteriormente é chamada de campanuliforme(Figura 2 B). A faringe de tipo colarinho apresenta as inserção dorsais deslocada muito posteriormente (Figura $2 \mathrm{C}$ ).

\section{Figura 2}
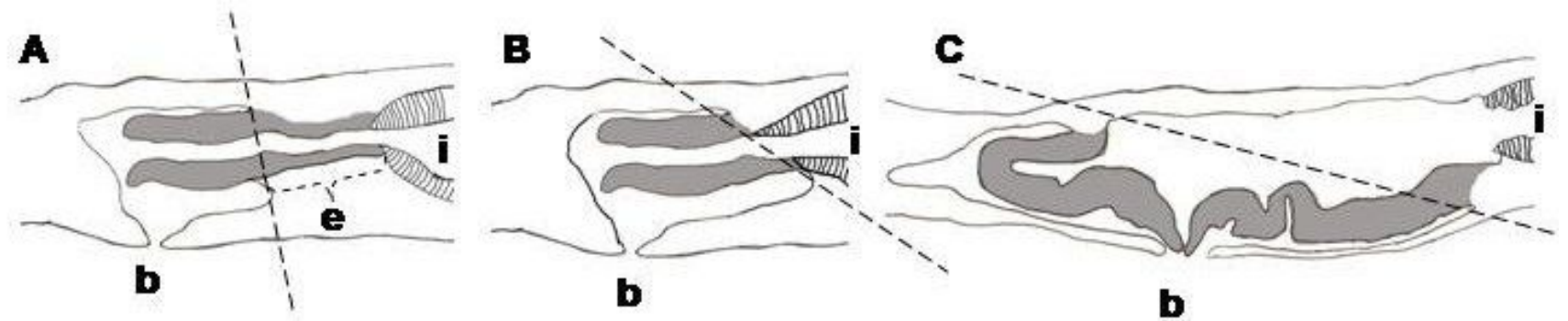

Figura 2. Tipos de faringe que possuem as planárias terrestres. A, faringe cilíndrica, B, faringe campanuliforme, C, faringe tipo colarinho. Abreviações; b: boca; e: esôfago; i: intestino.

O sistema nervoso central está localizado ventralmente em todas as planárias e está composto por um par de gânglios anteriores, ou cérebro, do qual estendem-se posteriormente dois cordões nervosos ou uma placa nervosa. Além do sistema nervoso central, um entrelaçamento de ramificações nervosas formam o plexo nervoso subepidérmico subjacente à musculatura subepidérmica.

Os gametas masculinos são produzidos em numerosos testículos, agrupados em duas fileiras de um ou vários testículos. Os testículos estão localizados dorsalmente em Geoplaninae e ventralmente nas outras famílias de Geoplanidae (Figura 3). Na subfamília Geoplaninae são normalmente distribuídos entre a região dos ovários e a da faringe. Um dúctulo dorso-ventral comunica os testículos com dutos eferentes, os quais conduzem os espermatozoides até a vesícula prostática localizada posteriormente à faringe.

Muitas vezes, parte a região proximal da vesícula é bifurcada. A vesícula pode estar 
dentro ou fora de um revestimento muscular que envolve o aparelho copulador, o qual recebe o nome de envoltório muscular comum. A vesícula se abre para o átrio masculino através de um duto ejaculatório ou uma cavidade ejaculatória. É muito comum encontrar uma papila peniana, cilíndrica ou cônica, na região proximal do átrio masculino, mas nem sempre existe. A papila peniana, quando existe, assenta-se uma base muscular chamada musculatura bulbar do pênis.

A papila peniana normalmente possui um duto ejaculatório que ajuda na condução dos espermatozoides. Nas espécies sem papila permanente, esta se forma protraindo a parede do átrio masculino. Nas espécies do gênero Artioposthia a papila está equipada com adenodáctilos (estruturas músculo-glandulares). Além da papila, o átrio pode ter dobras ou pode ser uma cavidade lisa. Normalmente, o poro genital ou gonóporo ocorre no ponto onde os átrios masculino e feminino se encontram. A comunicação entre os átrios pode ser completamente aberta ou separada por uma dobra dorsal ou uma constrição anelar causada por um esfíncter. Grande parte do epitélio do aparelho copulador é atravessado por glândulas e tem um sistema muscular constituído por uma ou mais camadas musculares.

Os gametas femininos são produzidos por um único par de ovários, localizados ventralmente, próximo ao gânglio cerebral. De cada ovário surge um duto ovovitelino, assim chamado por receber secreções dos vitelários e por conducir os ovos. Os dutos ovovitellinos estendem-se posteriormente e comunicam-se com o átrio feminino através de uma vagina. Na porção distal os dutos ovovitelinos recebem as secreções das glândulas da casca, que formam a parede externa do casulo. Os dutos ovovitelinos podem abrir-se independentemente na vagina, ou podem formar um duto glandular comum recebendo também as glândulas da casca.

A posição e a direção da porção distal do duto glandular comum e da vagina variam nos diferentes gêneros da Geoplaninae. $O$ átrio feminino encontra-se envolvidas por ele dentro do envoltório muscular comum, a vagina e o duto glandular comum nem sempre estão. O átrio feminino tem um tamanho variável em relação ao do átrio masculino, geralmente é um pouco menor. Como o sistema masculino, o epitélio dos canais e cavidades estão atravessados por glândulas e tem um revestimento muscular. Podem-se apresentar outras estruturas no átrio feminino; divertículos, bursas copuladoras ou um canal genitointestinal ocorrem normalmente nas subfamílias Bipaliinae, Microplaninae e Rhychodeminae. 


\section{Figura 3}

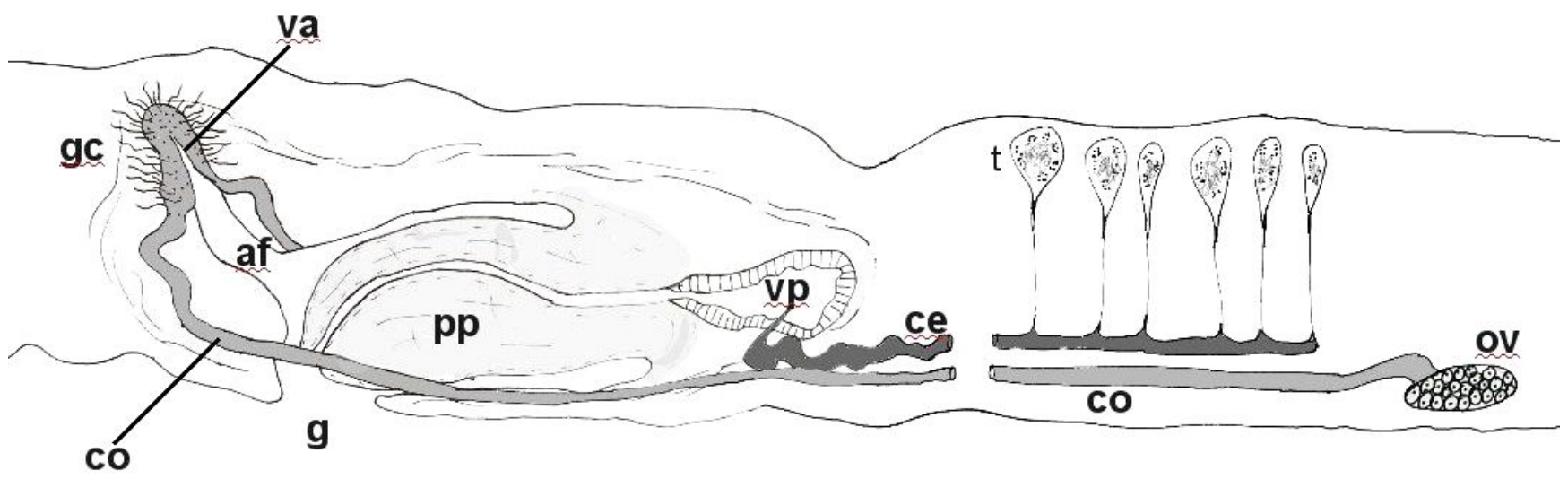

Figura 3. Aparelho copulador idealizado da subfamília Geoplaninae. Abreviações: af: Átrio feminino; ce: duto eferente; co: duto ovovitelino; g: gonóporo; gc: glândulas da casca; ov: ovário; pp: papila peniana; t: testículos; va: vagina; vp: vesícula prostática.

O envoltório muscular comum é uma camada muscular que envolve os órgãos copuladores; engloba os átrios masculino e feminino e muitas vezes também a vagina e a vesícula prostática ou parte dela.

\subsection{Sistemática}

A classificação atual (Sluys et al., 2009) dos Tricladida é baseada em estudos filogenéticos, principalmente com dados moleculares.

Conforme a classificação atual (Tabela 1.1), todas as planárias pertencem à ordem Tricladida (Platyhelminthes) e são caracterizadas por possuírem três ramos intestinais, o que dá nome ao grupo. Existem atualmente três subordens de tricládidos: marinhos (Maricola), de água doce e terrestres (Continenticola), e de cavernas (Cavernicola).

A subordem Continenticola, proposta por Carranza et al (1998), está atualmente composta por duas superfamílias: Planaroidea Stimpson, 1857 e Geoplanoidea Stimpson, 1857. Planaroidea é composta exclusivamente por planárias de água doce; Geoplanoidea abriga as planárias de água doce e as planárias terrestres. A superfamília Geoplanoidea é resultado da fusão das antigas subordens Paludicola e Terricola; este grupo taxonomico está sustentado principalmente por a duplicação do gene ribossomal $18 \mathrm{~S}$. 
Dentro da superfamília Geoplanoidea, existem duas famílias, Dugesiidae e Geoplanidae. A família Geoplanidae corresponde à antiga subordem Terricola, e compreende exclusivamente as a planárias terrestres.

As planárias terrestres (Geoplanidae) compreendem um universo de mais de 800 espécies classificadas em quatro subfamílias. A subfamília Bipaliinae compreende espécies principalmente asiáticas. A subfamília Microplaninae é caracterizada por possuir só dois olhos na extremo anterior. A subfamília Rhychodeminae contem cinco tribos: Rhynchodemini, Caenoplanini, Anzoplanini, Eudoxiatopoplanini e Pelmatoplanini. A tribo Caenoplanini está formada por 174 espécies e distribui-se principalmente em Austrália, Nova Zelândia e o resto do Pacífico notogeico. A tribo Eudoxiatopoplanini contem uma única especie, Eudoxiatopoplana bilaticlavia Winsor, 2009 da ilha Stewart em Nova Zelândia. A tribo Anzoplanini que contém dois gêneros das ilhas subantárticas da Nova Zelândia. A tribo Pelmatoplaninae é composta por 16 espécies repartidas em dois gêneros, todos ocorrentes em regiões orientais e na Colômbia (Ogren et al., 1997). Estas quatro tribos (Caenoplanini, Anzoplanini, Eudoxiatopoplanini e Pelmatoplanini) tinham categoria de subfamília na classificação anterior, e junto com a subfamília Geoplaninae, formavam a família Geoplanidae. A tribo Rhynchodemini, tinha categoria de subfamília e era considerada grupo irmão de Microplaninae; ambas formavam a família Rhynchodemidae na classificação anterior.

A subfamília Geoplaninae é o objeto principal deste estudo. Geoplaninae está composta por 16 gêneros e umas 260 especies que são exclusivamente neotropicais e são caracterizadas por possuírem testículos dorsais e uma única fileira de olhos na extremidade anterior. 
Tabela 1.1 Classificação sistemática da subfamília Geoplaninae Stimpson, 1857 conforme classificação de Sluys et al (2009). * indica gênero coletivo.

Ordem TRICLADIDA Lang, 1884

Subordem MARICOLA Hallez, 1892

Subordem CONTINENTICOLA Carranza et al, 1998

Subordem CAVERNICOLA Sluys, 1990

Superfamília PLANARIOIDEA Stimpson, 1857

Família PLANARIIDAE Stimpson, 1857

Superfamília GEOPLANOIDEA Stimpson, 1857

Família DUGESIIDAE Ball, 1974

Família GEOPLANIDAE Stimpson, 1857

Subfamília BIPALIINAE Von Graff, 1896

Subfamília MICROPLANINAE Pantin, 1953

Subfamília RHYNCHODEMINAE Von Graff, 1896

Subfamília GEOPLANINAE Stimpson, 1857

Gênero Amaga Ogren and Kawakatsu, 1990

Gênero Cephaloflexa Carbayo and Leal-Zanchet, 2003

Gênero Choeradoplana Von Graff, 1896

Gênero Enterosyringa Ogren and Kawakatsu,1990

Gênero Geobia Diesing, 1861

Gênero Geoplana Stimpson, 1857

Subgênero Barreirana Ogren and Kawakatsu, 1990

Subgênero Geoplana Stimpson, 1857

Gênero Gigantea Ogren and Kawakatsu, 1990

Gênero Gusana E. M. Froehlich, 1978

Gênero Issoca C. G. Froehlich, 1978

Gênero Liana E. M. Froehlich, 1978

Gênero Luteustriata Carbayo, 2010 (no prelo)

Gênero Notogynaphallia Ogren and Kawakatsu, 1990

Gênero Pasipha Ogren and Kawakatsu, 1990

Gênero Polycladus Blanchard, 1845

Gênero Pseudogeoplana Ogren and Kawakatsu, 1990*

Gênero Supramontana Carbayo and Leal-Zanchet, 2003

Gênero Xerapoa C. G. Froehlich, 1955 


\subsection{Sistemática e filogenia de Geoplaninae: estado de conhecimento}

Muitas das descrições das espécies da subfamília Geoplaninae, sobre tudo as descritas até meados do séc. $X X$, registravam apenas caracteres diagnósticos. $O$ monofiletismo da subfamília ainda não foi testado, embora estudos moleculares de Tricladida sugerem que a subfamília é monofilética (Carranza et al., 1998; Baguñà et al., 2001; ÁlvarezPresas et al., 2008). Geralmente os gêneros foram caracterizados tipologicamente por uma combinação única de caracteres morfológicos (Carbayo \& Leal-Zanchet, 2003). Essas caracterizações nem sempre contemplam estruturas previamente tratadas em outros gêneros, de modo que com a informação disponivel não é possível fazer uma análise comparativa dessas estruturas para o conjunto da subfamília sem revisar esses gêneros. Esta circunstância não se restringe a Geoplaninae, mas se estende para os táxons das outras subfamílias e tribos de Geoplanidae. Exceções são dois gêneros orientais da subfamília Bipaliinae Graff, 1896, Novibipalium Kawakatsu et al., 1998 e Humbertium Ogren \& Sluys, 2001, caracterizados, respectivamente, pela condição apomórfica de caracteres dos órgãos reprodutivos num contexto filogenético. Dadas as dificuldades de analisarem o possível grupo irmão de Bipaliinae, os autores combinaram caracteres de espécies de grupos externos num grupo externo artificial para a reconstrução filogenética (Ogren \& Sluys, 1998; 2001).

A primeira proposta filogenética para Geoplanidae deve-se a Graff (1899). O autor teceu alguns comentários sobre a filogenia das planárias terrestres do mundo e subdividiu o gênero Geoplana sensu Stimpson, 1857 em três grupos não formais, diferenciados pelo tipo e grau de desenvolvimento dos sistemas musculares subepidérmico e mesenquimático. As espécies do grupo Geoplana-a sensu Graff 1899 (hoje Geoplana sensu stricto), com feixes subepidérmicos muito fortes e feixes mesenquimáticos longitudinais ausentes, característico das espécies neotropicais largas e chatas; elas teriam dado origem a todas as outras espécies de Geoplanidae. As espécies do grupo Geoplana-b sensu Graff, 1899 são caracterizadas por terem feixes subepidérmicos mais fracos que as espécies de Geoplana-a e não terem feixes mesenquimáticos, o que e típico das espécies da Austrália, alongadas e plano-convexas. Por último, as espécies do grupo Geoplana-c sensu Graff, 1899 têm feixes subepidérmicos relativamente mais fortes que das espécies de Geoplana-a, e ademais, um tubo frouxo de fibras mesenquimáticas, característico das espécies pequenas e 
subcilíndricas.

Graff considerou também a posição dos testículos, ventral ou dorsal, como um caráter importante e dividiu Geoplana em grupos não formais de espécies com testículos dorsais, tipicamente neotropical, e grupos de espécies com testículos ventrais, espécies orientais e australianas (Graff, 1899). Meixner (1928) propôs que as espécies do grupo Geoplana-a não seriam um grupo basal, mas derivado, e que tribo Pelmatoplaninae seria o grupo irmão das atuais Geoplaninae.

Num estudo sobre as planárias terrestres brasileiras, E. M. Froehlich (1955) criou agrupamentos não formais de espécies com critérios morfológicos. Froehlich (1955) restringiu as espécies de Geoplana sensu Graff a apenas espécies de Geoplana neotropicais, quer dizer, àquelas do grupo Geoplana-a, que têm feixes subepidérmicos muito fortes, feixes mesenquimáticos longitudinais ausentes, e testículos dorsais. Froehlich (1967) apresentou aspectos zoogeográficos de Geoplanidae e subdividiu, concordando parcialmente com a proposta de E. M. Froehlich (1955), parte das espécies de Geoplana sensu stricto em oito agrupamentos não formais conforme características morfológicas e distribuição geográfica. O autor evitou formalizar a subdivisão por causa da mudança gradual dos caracteres entre uns grupos e outros (Froehlich, 1967).

Finalmente, Ogren \& Kawakatsu $(1990,1991)$ erigiram a subfamília Geoplaninae para as espécies de Geoplanidae com testículos dorsais; musculatura longitudinal subepidérmica bem desenvolvida, em feixes; musculatura longitudinal mesenquimática ausente ou pouco desenvolvida e sem formar um anel circular, isto é, as espécies do grupo Geoplana-a de Graff (1899), ou as espécies de Geoplana sensu stricto de Froehlich (1955). Os autores também elevaram à categoria de gênero alguns grupos informais de Geoplana sensu stricto propostos por Froehlich (1967). Estas subdivisões foram feitas a partir de uma revisão da literatura, sem exame do material biológico. Aquelas espécies com características morfológicas insuficientemente conhecidas, especialmente as do aparelho copulador, foram alojadas no gênero coletivo Pseudogeoplana Ogren \& Kawakatsu, 1990.

A localização dorsal o ventral dos testículos é um caráter importante na sistemática de Geoplanidae. As discussões filogenéticas e biogeográficas de Geoplaninae podem se tornar mais enriquecedoras após a recente descrição da nova tribo Anzoplanini (subfamília Rhychodeminae), da Austrália, Nova Zelândia e ilhas subantárticas, com testículos dorsais e 
ventrais simultaneamente (Winsor, 2006), e com a nova tribo Eudoxiatopoplanini da ilha Stewart (Nova Zelândia), com testículos apenas dorsais (Winsor, 2009). Até o momento, a posição dorsal dos testículos era considerada uma condição derivada, encontrada só em planárias terrestres neotropicais e sugere conexões continentais gonduânicas.

Alguns autores têm questionado o monofiletismo de alguns dos gêneros de Geoplaninae. Exames morfológicos detalhados, de espécies novas e de espécies conhecidas, têm revelado (a) a existência de novos caracteres potencialmente informativos para a filogenia, e (b) a heterogeneidade de vários gêneros. O gênero Notogynaphallia tem sido objeto de maior número de trabalhos. Leal-Zanchet \& Carbayo (2001), mostraram a heterogeneidade de Notogynaphallia. Leal-Zanchet \& E. M. Froehlich $(2001,2006)$ e E. M. Froehlich \& Leal-Zanchet (2003) mostraram a existência de um complexo de espécies dentro de Notogynaphallia. Carbayo (2006) propôs estruturas musculares e glandulares na região cefálica - condições derivadas em algumas das espécies do complexo- , para sustentar a proposição de um gênero novo.

Carbayo $(2003,2005)$, numa revisão da literatura e análise dos espécimes, identificou e polarizou tentativamente 38 caracteres de potencial importância sistemática para a subfamília. Os caracteres identificados evidenciam que ao menos Geoplana, Gigantea Ogren \& Kawakatsu, 1990, Notogynaphallia Ogren \& Kawakatsu, 1990 e Pasipha Ogren \& Kawakatsu, 1990 são polifiléticos. Estes caracteres poderiam ser usados para testar o monofiletismo dos gêneros e propor hipóteses de relacionamento filogenético entre eles. A comparação das árvores resultantes da sistemática filogenética com a filogenia molecular poderia corroborar ou rejeitar hipóteses de relacionamento entre os grupos.

Distinguem-se três agrupamentos de espécies de Geoplaninae à luz do conhecimento dos caracteres morfológicos importantes para a reconstrução de relacionamenrtos filogenéticos. Para cada espécie citam-se as referências que contêm informações morfológicas:

a) Espécies bem conhecidas: Supramontana irritata Carbayo \& Leal-Zanchet, 2003; Cephaloflexa bergi (Riester, 1938).; Notogynaphallia plumbea (Froehlich, 1956) (Carbayo, 2003); Choeradoplana iheringi Graff, 1896 (Leal-Zanchet \& Souza, 2003; Carbayo \& Leal-Zanchet 2003). 
b) Espécies-tipo incompletamente conhecidas. Inclui espécies com características diagnósticas conhecidas, mas a anatomia interna não se encontra completamente descrita. São estas: Issoca rezendei Froehlich, 1955 (Froehlich, 1955; Carbayo \& LealZanchet, 2003); Liana guasa E. M. Froehlich, 1978 e Gusana cruciata E. M. Froehlich, 1978 (E. M. Froehlich, 1978); Polycladus gayi Blanchard, 1845 (Graff, 1899; Schmidt, 1902); Geoplana vaginuloides (Darwin, 1844) (Froehlich, 1955); Xerapoa hystrix Froehlich, 1955; Geobia subterranea (Schultze \& Müller, 1857); Enterosyringa pseudorhynchodemus (Riester, 1938) (Marcus, 1951).

c) Espécies-tipo insuficientemente conhecidas. São espécies-tipo de gêneros resultantes da subdivisão de Geoplana feita por Ogren \& Kawakatsu (1990). São estas: Amaga amagensis Ogren \& Kawakatsu, 1990; Gigantea gigantea Ogren \& Kawakatsu, 1990; Pasipha pasipha Ogren \& Kawakatsu, 1990.

O objetivo primário deste estudo é propor a primeira filogenia da subfamília Geoplaninae a nível de gênero com dados morfológicos resultantes do exame das especies tipo e da literatura. E secundariamente, detalhar a morfologia das especies tipo subfamília Geoplaninae. 


\section{Referências bibliográficas}

Alford, D. V. 1998. Potential problems posed by non-indigenous terrestrial flatworms in the United Kingdom. Pedobiologia, 42: 574-578.

Alvarez-Presas, M, Baguñà J, \& Riutort M. 2008. Molecular phylogeny of land and freshwater planarians (Tricladida, Platyhelminthes): from freshwater to land and back. Molecular Phylogenetics and Evolultion, 47:555-568.

Baguñá, J.; Carranza, S.; Paps, J.; Ruiz-Trillo, I. \& Riutort, M. 2001. Molecular taxonomy and phylogeny of the Tricladida. Chapter 6: 49-56. In: Littlewood, D.T.J. and Bray, R.A. (eds) Interrelationships of the Platyhelminthes. Systematics Association Special Volume Series.

Carbayo, F. 2003. Revisión de Notogynaphallia Ogren \& Kawakatsu, 1990 (Platyhelminthes, Tricladida). Tese de doutorado. Universidad de Salamanca.

Carbayo, F. 2005. Procedimentos de campo e laboratório para a caracterização das planárias terrestres neotropicais (Platyhelminthes: Tricladida). Caderno La Salle XI, Canoas, 2 (1): 131-144.

Carbayo, F. 2006. Redescription of two land planarian species of Notogynaphallia Ogren \& Kawakatsu (Platyhelminthes, Tricladida, Geoplaninae) and confirmation of the heterogeneity of the genus. Revista Brasileira de Zoologia, 23 (3): 746-757.

Carbayo, F. 2007. A new species of land planarian of Gigantea Ogren and Kawakatsu, 1990 (Platyhelminthes: Tricladida: Terricola) from Colombia, with taxonomic remarks on the genus. Italian Journal of Zoology, 75(1): 85-95.

Carbayo, F. \& Leal-Zanchet, A.M. 2000. Fauna de planárias terrestres (Platyhelminthes: Tricladida: Terrricola) na Floresta Nacional de São Francisco de Paula-RS: uma análise preliminar. Acta Biologica Leopoldensia, São Leopoldo, v. 22, n. 1, p. 19-25.

Carbayo, F.; Leal-Zanchet, A.M. \& Vieira, E.M. 2002. Terrestrial flatworm (Platyhelminthes: Tricladida: Terricola) diversity vs. man-induced disturbance in a subtropical rainforest from Southern Brazil. Biodiversity and Conservation, 11: 1091-1104.

Carbayo, F. \& Leal-Zanchet, A.M. 2003. Two new genera of Geoplaninae (Terricola: Tricladida: Platyhelminthes) of Brazil in the light of cephalic specialisations. Invertebrate Systematics, 17 (3): 449-468. 
Carranza, S.; Ruiz-Trillo, I.; Littlewood, D.T.J.; Riutort, M. \& Baguñà, J. 1998b. A reappraisal of the phylogenetic and taxonomic position of land planarians (Platyhelminthes, Turbellaria, Tricladida) inferred from 18S rDNA sequences. Pedobiologia, 42: 433-440.

Darwin, C. 1844. Brief descriptions of several terrestrial planariae, and of some remarkable marine species, with an accopunt of their habits. Quaterly Journal Microscopic Society, 91 (2): 209-214 +1 lám.

Fernandes, M. C.; Alvares, E. P.; Gama, P.; Silveira M. 2001. The sensory border of the land planarian Bipalium kewense (Platyhelminthes, Tricladida, Terricola). Belgian Journal Of Zoology, v. 131, suppl. 5-9.

Froehlich, C.G. 1955. On the biology of land planarians. Boletim da Faculdade de Filosofia,

Ciências e Letras da Universidade de São Paulo, série Zoologia, 20:263-271.

Froehlich, C.G. 1967. A contribution to the zoogeography of neotropical land planarians. Acta Zoologica Lilloana 23: 153-162.

Froehlich, E.M. 1955. Sobre espécies brasileiras do gênero Geoplana. Boletim da Faculdade de Filosofia, Ciências e Letras da Universidade de São Paulo, série Zoologia, 19: 289-369.

Froehlich, E.M. 1978. On a collection of chilean landplanarians. Boletim de Zoologia Universidade de São Paulo 3: 7-80.

Froehlich, E.M. \& Leal-Zanchet, A.M. 2003. A new species of terrestrial planarian of the genus Notogynaphallia (Platyhelminthes, Tricladida, Terricola) from south Brazil and some comments on the genus. Revista Brasileira de Zoologia, 20 (4): 745-753.

Garrick, R.C.; Sands, C.J.; Rowell, D.M.; Tait, N.N.; Greenslade, P. \& Sunnucks, P. 2004. Phylogeography recapitulates topography: very fine-scale local endemism of a saproxylic giant springtail at Tallaganda in the Great Dividing Range of south-east Australia. Molecular Ecology, 13: 329-3344.

Kawaguti, S. 1932. On the physiology of land planarians. Memoirs of the Faculty of Science and Agriculture, Taihoku Imperial University 7:15-55

Kawakatsu, M.; Ogren, R.E. and Muniappan, R. 1992. Redescription of Platydemus manokwari de Beauchamp, 1962 (Turbellaria: Tricladida: Terricola) from Guam and the Philippines. Proceedings of Japanese Society of Systematic Zoology 47: 11-25 
Kawakatsu, M.; Makino, N. \& Shirasawa, Y. 1982. Bipalium nobile sp. nov. (Turbellaria, Tricladida, Terricola), a new land planarian form Tokyo. Annotations Zoologicae Japonenses, 55 (4): 236-262.

Kawakatsu, M.; Ogren, R.O.; Froehlich, E.M. \& Murayama, H. 2001. On the places of origin of three, very large Bipaliid land planarians from Japan (Turbellaria, Seriata, Tricladida, Terricola). Shibukitsubo 22: 39-52.

Leal-Zanchet, A.M. \& Carbayo, F. 2000. Fauna de planárias terrestres da Floresta Nacional de São Francisco de Paula, RS: uma análise preliminar. Acta Biologica Leopoldensia 22 (1): $19-25$.

Leal-Zanchet, A.M. \& Carbayo, F. 2001. Two new species of Geoplanidae (Platyhelminthes, Tricladida, Terricola) from Brazil. Jounral of Zoology, 253: 433-446.

Leal-Zanchet, A.M. \& Froehlich, E. M. 2001. A species complex in the genus Notogynaphallia (Tricladida: Terricola). Belgian Journal of Zoology, 131 (supl): 225226.

Leal-Zanchet, A.M. \& Froehlich, E. M. 2006. A species complex in the genus Notogynaphallia Ogren and Kawakatsu (Platyhelminthes: Tricladida: Terricola) with a taxonomic revision of homonyms of Geoplana marginata Schultze \& Müller and a reinterpretation of Notogynaphallia caissara (Froehlich) anatomy. Belgian Journal of Zoology,136 (1): 81-100.

Leal-Zanchet, A. M. \& Souza, S. A. 2003. Redescrição de Choeradoplana iheringi Graff (Platyhelminthes, Tricladida, Terricola). Revista Brasileira de Zoologia, 20(3): 523-530.

Marcus, E. 1951. Turbellaria brasileiros (9). Boletim da Faculdade de Filosofia, Ciências e Letras da Universidade de São Paulo, série Zoologia, 16: 5-215.

Meixner, J. 1928. Der Genitalapparat der Tricladen und seine Beziehungen zu ihrer allgemeinen Morphologie, Phylogenie, Okologie und Verbreitung. Zeitschrift für Morphologie und Ökologie der Tiere 11 (5): 570-612.

Ogren, R.E. 1995. Predation behaviour of land planarians. Hydrobiologia, 305: 105-111.

Ogren, R.E. \& Kawakatsu, M. 1990. Index to the species of the family Geoplanidae (Turbellaria, Tricladida, Terricola) Part I: Geoplaninae. Bulletin Fuji Women's College 28 (I): 79-166.

Ogren, R.E. \& Kawakatsu, M. 1991. Index to the species of the family Geoplanidae 
(Turbellaria, Tricladida, Terricola) Part II: Caenoplaninae and Pelmatoplaninae. Bulletin Fuji Womens College 29 (II): 25-102.

Ogren, R.E.; Kawakatsu, M. \& Froehlich, E. M. 1997. Additions and corrections of the previous land planarian indices of the world (Turbellaria, Seriata, Tricladida, Terricola). Adendum IV. Geographic locus index: Bipaliidae; Rhynchodemidae (Rhynchodeminae; Microplaninae); Geoplanidae (Geoplaninae; Caenoplaninae; Pelmatoplaninae. Bull. Fuji Women's College 35 (II): 63-103.

Ogren, R.E. \& Sluys, R. 1998. Selected characters of the copulatory organs in the land planarian family Bipaliidae and their taxonomic significance (Tricladida: Terricola). Hydrobiologia, 383: 77-82.

Ogren, R.E. \& Sluys, R. 2001. The genus Humbertium gen. nov., a new taxon of the land planarian family Bipaliidae (Tricladida: Terricola). Belgian Journal of Zoology, 131 (Suppl. 1):201-204.

Riester A. 1938. Beiträge zur Geoplaniden-Fauna Brasiliens. Abhandlung Senckenbergische Naturforschende Gesellschaft, 441: 1-88.

Schauble, C.S. \& Moritz, C. 2001. Comparative phylogeography of two open forest frogs from eastern Australia. Biological Journal of the Linnean Society, 74, 157-170.

Schmidt, 1902. Zur Kenntnis der Tricladenaugen und der Anatomie von Polycladus gayi. Zeitschrift fur Wissenschaftliche Zoologie 72: 545-564, + 2 láms.

Schultze, M. \& Müller, F. 1857. Beiträge zur Kenntnis der Landplanarien, nach Mithheilungen des Dr. Fritz Müller in Brasilien und nach eigenen Untersuchungen von Dr. Max Schultze. Abhandlung Naturforschende Gesellschaft Halle, 4: 61-74.

Sugiura, S., Okochi, I. \& Tamada, H. 2006. High predation pressure by an introduced flatworm on land snails on the oceanic Ogasawara Islands. Biotropica, 38 (5): 700-703.

Sluys, R. 1999. Global diversity of land planarians (Platyhelminthes, Tricladida, Terricola): a new indicator-taxon in biodiversity and conservation studies. Biodiversity and Conservation 8:1663-1681.

Sluys, R. 2001. Towards a phylogenetic classification and characterization of Dugesiid genera (Platyhelminthes, Tricladida, Dugesiidae): a morphological perspective. In: Littlewood, D.T.J. \& Bray, R. A. (eds.). Interrelationships of the Platyhelminthes. Syst. Ass Spec. Vol, Ser. 60 Taylor \& Francis, London and New York, pp. 57-73. 
Sluys, R.; Kawakatsu, M.; Riutort, M. \& Baguñà, J. 2009. A new higher classification of planarian flatworms (Platyhelminthes, Tricladida). Journal of Natural History, 43:29,1763-1777

Sunnucks, P.; Blacket, M. J.; Taylor, J. M.; Sands, C. J.; Ciavaglia, S. A.; Garrick, R. C.; Tait, N. N.; Rowell, D. M. \& Pavlova, A. 2006. A tale of two flatties: different responses of two terrestrial flatworms to past environmental climatic fluctuations at Tallaganda in montane southeastern Australia. Molecular Ecology, 15: 4513-4531.

Von Graff, L. 1899. Monographie der Turbellarien: II. Tricladida Terricola. Engelmann, Leipzig.

Winsor, L. 1998a. Collection, handeleing, fixation, histological and storage procedures for taxonomic studies of terrestrial flatworms (Tricladida: Terricola). Pedobiologia 42: 405411.

Winsor, L. 1998b. Aspects of taxonomy and functional histology in terrestrial flatworms (Tricladida: Terricola). Pedobiologia, 42: 412-432.

Winsor, L. 2006. New and revised terrestrial flatworm taxa (Platyhelminthes: Tricladida: Terricola) of Australia and the Subantarctic Islands of New Zealand. Tuhinga, 17: 81104.

Winsor, L. 2009. A new subfamily, new genus and new specie of terrestrial flatworm (Platyhelminthes:Tricladida: Geoplanidae) from Stewart Island, New Zealand. Tuhinga, 20: $23-32$

Winsor, L.; Johns, P.M. \& Yeates, G.W. 1998. Introduction, and ecological and systematic background, to the Terricola (Tricladida). Pedobiologia, 42: 389-404. 


\section{Capítulo 2}

\section{Descriptions of type species}

Taxonomic characters may function as diagnostic characters for a particular species or as indicators of relationship. Failure to recognize these two principal function of a taxonomic character has led to much sterile discussion by taxonomists on the relative values of given characters. It follows that a species description which provides only the minimum of diagnostic characters is of little value to the evolutionist and the biogeographer, even though the description is adequate for the recognition of the species.

Ian R. Ball (1974) 


\section{Introduction}

Land planarians (family Geoplanidae) belong to the soil ecosystem, they live in humid environments of the forest floor and often exhibit brightly colored patterns. They range between 1 to $20 \mathrm{~cm}$ in size and are successful predators of other invertebrates (Ogren 1995).

The Geoplanidae family is composed of four subfamilies: the subfamilies Rhychodeminae and Microplaninae are characterized by having two eyes in the anterior end of the body; the Bipaliinae subfamily, which comprehends Asiatic species with a characteristic expanded head. And the Geoplaninae, a subfamily of Neotropical land planarians which is the focus of the present paper.

The Geoplaninae appears to be a very diverse group spread throughout the whole of Central and South America (Froehlich, 1967; Hyman,1962). At this present state, there is a taxonomical hazard that obstructs a natural classification of the land planarians. The poor morphological knowledge of type species is impeding a modern systematization of the group. Normally there are few type specimens if any, and they are hard to obtain and study. Because the majority of type specimens have been deposited many decades ago throughout museums in different countries and their conservation state is not ideally preserved for histology which hampers in most cases the examination of the internal morphology of the specimens. In some cases the type material has been mounted whole and in others, the animal have no been adequately fixed and preserved.

For the neotropical subfamily Geoplaninae, the descriptions and generic diagnosis of its 16 genera generally include only a combination of gross morphological features of the copulatory apparatus, with the remaining body regions unstudied (Carbayo \& Zanchet 2003). Because not all these diagnoses are based on apomorphies, an evolutionary perspective on the Geoplaninae is obstructed. The main aim of this study is to morphologically describe the type material, when available, of the type-species of the extant geoplaninid genera, paying special attention to the phylogenetically putatively informative structures suggested by (Carbayo \& Zanchet 2003)

\section{Materials and methods}

The animals studied come from South America, specifically Brazil, Colombia, Chile, and Venezuela. We also studied material from Australia and Indonesia as outgroups. Two specimens, the holotype of Gigantea gigantea (von Graff, 1899) and recently collected material of Geoplana vaginuloides (Darwin, 1844) have been sectioned specifically for this 
study. Histological process was carried out according to Winsor (1998) and Carbayo (2005). Histological preparations were studied with compound microscopes. Drawings were made with aid of drawing tubes.

\section{Remarks on the material examined}

Some of the type material was studied in museums. Polycladus gayi Blanchard, 1845, Pelmatoplana moluccana von Graff, 1899 and Bipalium kewense Moseley, 1878 were studied at the Naturhistorisches Museum Wien, Austria. Gigantea gigantea (von Graff, 1899) has been studied at the Museum für Naturkunde Berlin, Germany. The rest of the material was studied at the Universidade de São Paulo, SP, Brazil. In some cases, the condition for studying the animals and the preservation state of the material has not been optimal, therefore the quality of descriptions, figures and photographs are not standard. Unfortunately, for some historical material the information on the labels on the histological slides is unsufficient for unequivocal specimen identification. In these cases we have reproduced ipsis litteris the complete data anotated on the labels.

We have written telegraphic descriptions paying special attention to morphological characters with presumed importance in a phylogenetic context. Each description is illustrated with drawings and photographs. 


\section{Abbreviations for institutions and private collections:}

EMF: Scientific collection of Eudoxia Maria Froehlich, Universidade de São Paulo, SP, Brazil.

FCB: Scientific collection of Fernando Carbayo, Universidade de São Paulo, SP, Brazil.

IPP: Instituto de Pesquisas de Planárias, Universidade do Vale do Rio dos Sinos, RS, Brazil.

NHM: Natural History Museum, London. UK.

NHMW: Naturhistorisches Museum Wien. Austria.

ZMA: Zoological Museum Amsterdam, Universiteit van Amsterdam, The Netherlands.

ZMB: Zoologisches Museum Berlin. Naturkunde Museum Berlin, Germany.

\section{Abbreviations to the figures:}

\begin{tabular}{|c|c|c|c|}
\hline b & brain & $\mathbf{m}$ & muscular fiber \\
\hline ced & common efferent ducts & mgo & musculo-glandular organ \\
\hline cg & common glandular duct & ov & ovary \\
\hline cm & common muscular coat & od & ovovitelline duct \\
\hline co & common oviduct & pa & parasite \\
\hline CS & creeping sole & pb & penis bulb \\
\hline dd & dorsal double diagonal mesenchymal musculature & pp & penis papilla \\
\hline de & dorsal epidermis & phe & pharyngeal external musculature \\
\hline dv & dorso-ventral mesenchymal musculature & phi & pharyngeal internal musculature \\
\hline ed & efferent duct & php & pharyngeal pouch \\
\hline ec & ejaculatory cavity & ph & pharynx \\
\hline es & esophagus & pv & prostatic vesicle \\
\hline ey & eyes & $\mathbf{r}$ & retractor muscle \\
\hline fa & female genital atrium & rb & rhabditogen cells \\
\hline gl & glands & p & sensory pit \\
\hline gb & glandular border & sc & central nervous system \\
\hline gc & glandular canal & sg & shell glands \\
\hline gk & glandular keel & ci & sub-epidermal circular m \\
\hline g & gonopore & di & sub-epidermal double diagonal musculature \\
\hline iaf & Inter-atrial fold & snp & sub-epidermal nervous plexus \\
\hline I & intestine & sb & sub-intestinal transversal mesenchymal muscle layer \\
\hline In & longitudinal musculature normal & ddn & sub-neural double diagonal \\
\hline I & Iongitudinal musculature/fiber & sn & sub-neural transversal mesenchymatical layer \\
\hline li & Iongitudinal sub-epidermal musculature insunk & sp & supra-intestinal transversal mesenchymal muscle layer \\
\hline Ivp & longitudinal ventral plate & t & testicle \\
\hline ma & male genital atrium & $\mathbf{v}$ & vagina \\
\hline It & mesenchymal longitudinal tube & ve & ventral epidermis \\
\hline $\mathbf{m}$ & mouth & vi & vitellaria \\
\hline
\end{tabular}




\section{Descriptions}




\section{Amaga amagensis (Fuhrmann, 1914)}

\section{SYNONYMS}

Geoplana amagensis n. sp. Fuhrmann, 1914.

\section{EXAMINED MATERIAL}

NHM 1928. Holotype. NHM 1928.1.4.83-91+1920.1.4.112+1928.1.4.92-95, sagittal sections of the pharynx and copulatory organs; 1928.1.4.110-111+1928.1.4.113+1928.1.4.113-115, sagittal sections of the posterior end of a second animal; 1928.1.4.96-109, horizontal sections of the anterior end; 1928.1.4.116-120, horizontal sections of the anterior end; Cafetal la Camelia, south of the Amagá river valley, Colombia, alt. $1600-1800 \mathrm{~m}$.

\section{MORPHOLOGY}

External morphology. Flat leaf like body. (Figure 4E). Body height $1800 \mu \mathrm{m}$. Creeping sole wide and ciliated up to $90 \%$ of the body width.

Eye cup monolobulated and multicelular, ranging from 40-60 $\mu \mathrm{m}$ in diameter. Eyes distributed anteriorly in a single row. In pre-pharynx region the eyes extend dorsally in irregular rows. Sensory pits inconspicuous in anterior part. In pre-pharynx region they were absent.

Sub-epidermic musculature. Musculature tripartite. Longitudinal muscular layer packed in small separate bundles, stronger dorsally $(60-75 \mu \mathrm{m})$ than ventrally $(40-50 \mu \mathrm{m})$. Longitudinal musculature not insunk into mesenchym (Figure 4C). Same sub-epidermal muscular arrangement in the prepharynx and in the cephalic region.

Sub-epidermic secretions. Xanthophyll secretions accumulating at the laterals of the body and opening and body edge, resembling a glandular ridge (Figure 4B-4D). Dorso with rhabidtes forming cells insunk in the mesenchym, and the dorsal epithelium is densely packed with rhabdite cells, ventral epithelium devoid of rhabdites. Ventral epithelium nucleated. Dorsal epithelium (30 $\mu \mathrm{m})$ thicker than ventral $(20 \mu \mathrm{m})$.

Mesenchymal musculature. Weak, composed of few thin fibers in all 
directions, but concentrated in three main layers; Supra and sub-intestinal transversal, and a dorsal double diagonal. Longitudinal mesenchymal muscle fibers absent. Same mesenchymal muscular arrangement in the pre pharynx and in the cephalic region.

Digestive system. Pharynx incompletely mounted in type material. Mouth located at least $5600 \mu \mathrm{m}$ anterior to posterior end pharynx pouch. Long and flat collard type pharynx, very folded. Esophagus not present in slides. Pharyngeal pouch composed of longitudinal and circular muscle fibers, predominantly circular. External pharynx epithelium ciliated. External pharynx musculature composed of thin layers of longitudinal and circular musculature. Internal pharynx musculature not present in slides.

Central nervous system. Organized in flat plate type.

Male reproductive organs. Each testes communicates with the efferent duct of the same body side throughout a dorso-ventral duct. Testes globular, 200 x $320 \mu \mathrm{m}$. Located dorsally, placed above supra-intestinal transverse mesenchymal layer (Figure 4A). Arranged in multiple irregular rows on each side of the body. Extending from the ovaries region to the pre-pharynx. Relative position of efferent ducts to ovovitelline inconspicuous. Efferent ducts lined with flat squamous epithelium. Prostatic vesicle bifurcated, with branches extending backwards on the ventral side of the animal at least $2100 \mu \mathrm{m}$. (Figure 5B)The prostatic vesicle turns dorsally in a vertical manner and penetrates the common muscular coat at the top dorsal corner. The prostatic vesicle inner epithelium is cuboidal, nucleated and ciliated. Wrapped in thick circular muscular coating (20$25 \mu \mathrm{m})$ composed of circular and reticular muscle fibers. Prostatic vesicle surrounded granular basophyll secretions in its proximal half (Figure $5 \mathrm{C}$ ). Ejaculatory duct extends tortuously and opens through a small aperture to the male atrium. Eversible penis type. Vas deferens opening into each branch of the bifurcated prostatic vesicle. Male atrium 1,5 times longer than female atrium. The male atrium consists of an irregularly folded cavity composed of large dorsoventral folds that hang from the roof of the male atrium. Male atrium surrounded in granular basophyll secretions. Male atrium musculature composed of 
longitudinal and circular muscle fibers. Male atrium epithelium nucleated, non ciliated. Gonopore surrounded by granular acidophyll secretions.

Female reproductive organs. Ovaries globular, longer $(500 \mu \mathrm{m})$ than wider $(250 \mu \mathrm{m})$ placed in the anterior region of the body. Ovovitelline ducts emerge from external ventral part of each ovary. Ovaries embedded in transversal subintestinal mesenchymal layer. The ovovitelline ducts ascend in a 45 degree angle, posterior to gonopore, and connect directly to the vagina. Ovovitelline receiving shell glands in last portion of the ascend. Ovovitelline musculature composed of reticular muscle fibers. Vagina opening to the dorsal most posterior corner of the female atrium (Figure 5A). Female atrium consists of a open unfolded cavity lined with pseudo-stratified non-ciliated epithelium. Female atrium musculature composed of longitudinal and circular muscle fibers. Common muscular coat wrapping both atriums and vagina. Composed of fibers in all directions. 

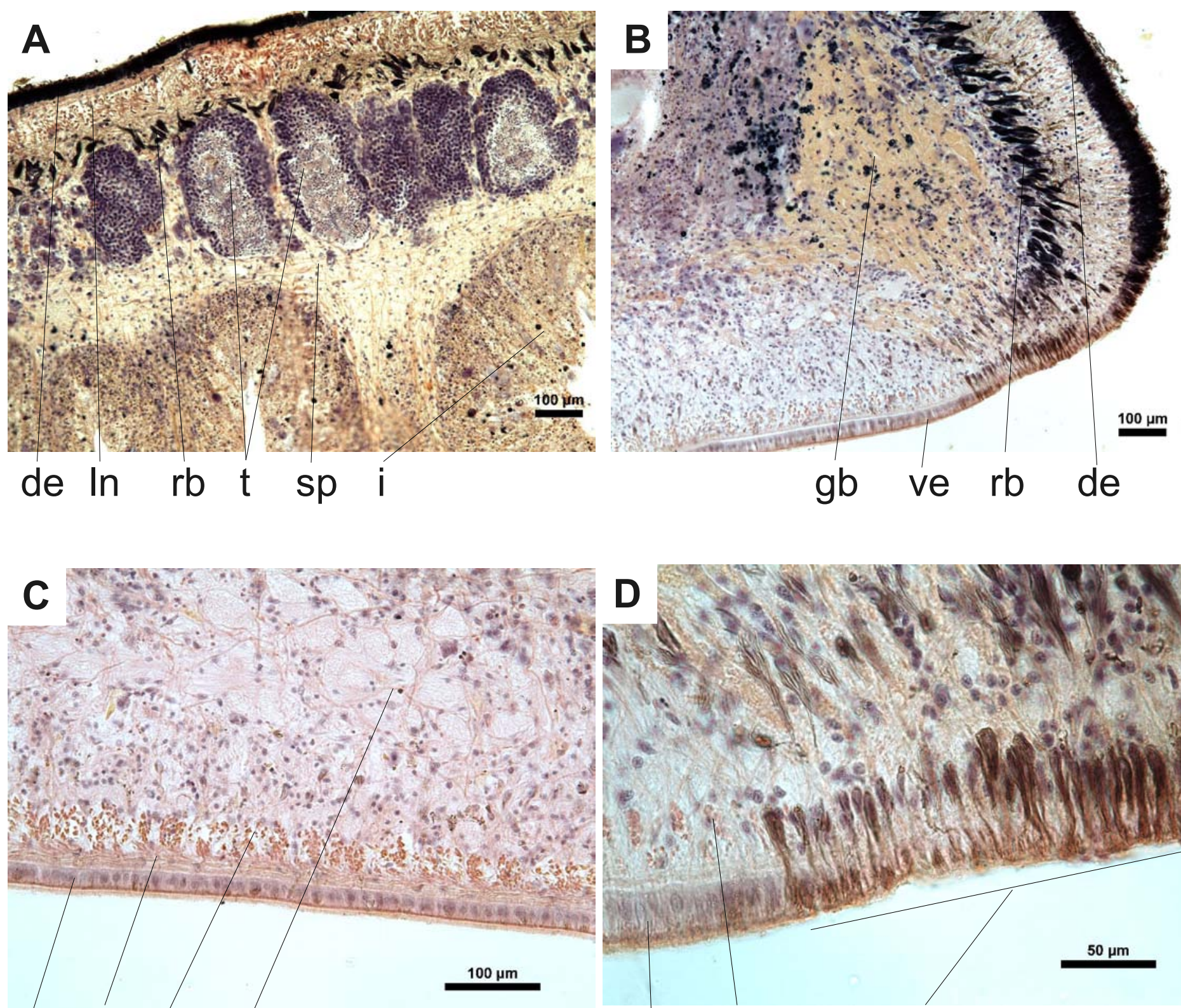

ve di In sc
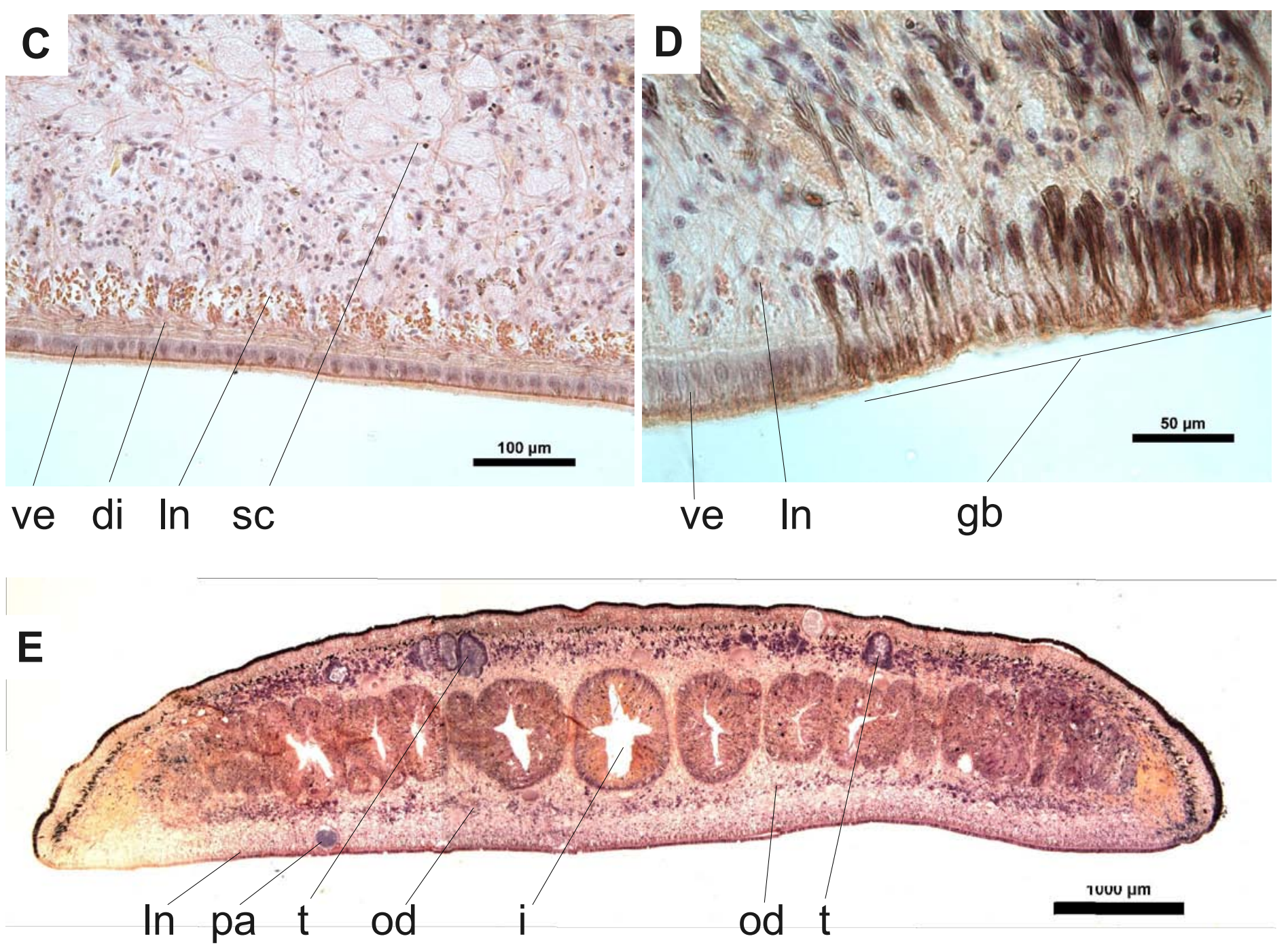

Amaga amagensis (Fuhrmann, 1914). Figure 4. Holotype. A) Photograph of testes, scale bar: $100 \mu \mathrm{m}$. B) Photograph of glandular border, scale bar: $250 \mu \mathrm{m}$. C) Photograph of ventral subepidermal musculature, scale . D) Photograph of glandular ridge, scale bar $50 \mu \mathrm{m}$. E) Photograph of transversal section, scale bar $1 \mathrm{~mm}$. 
A

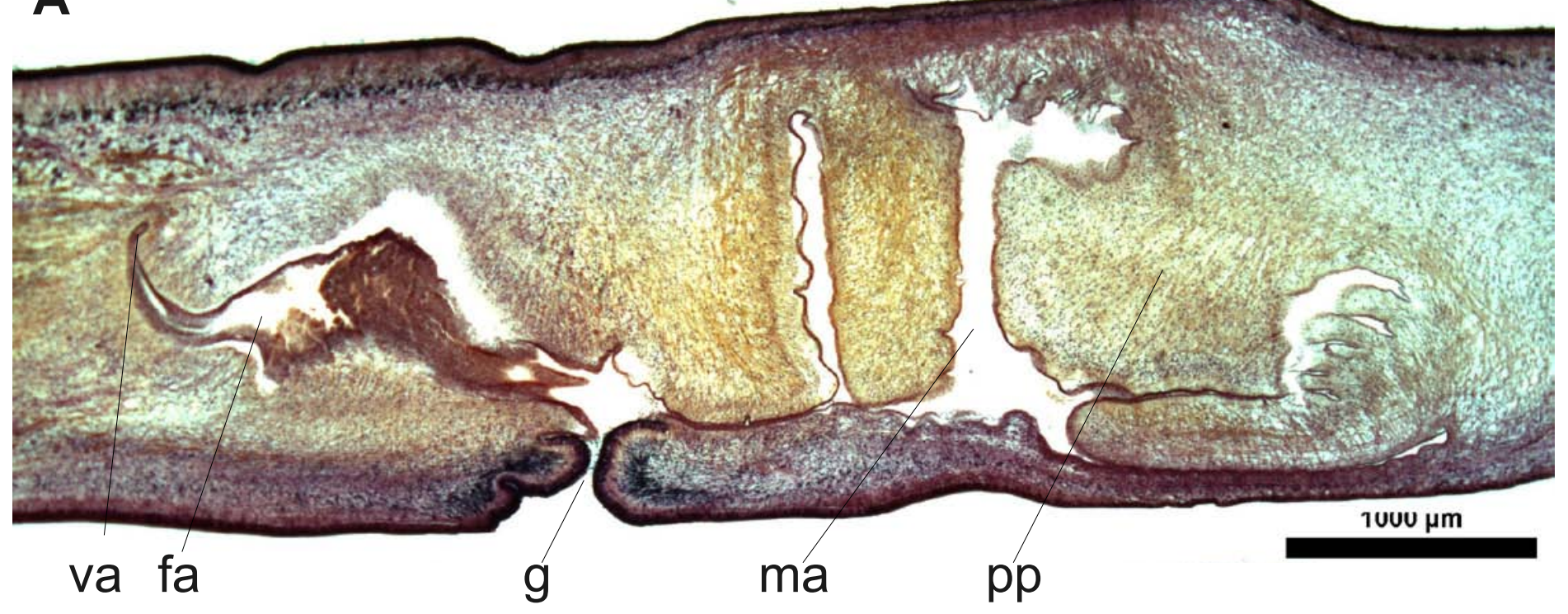

B

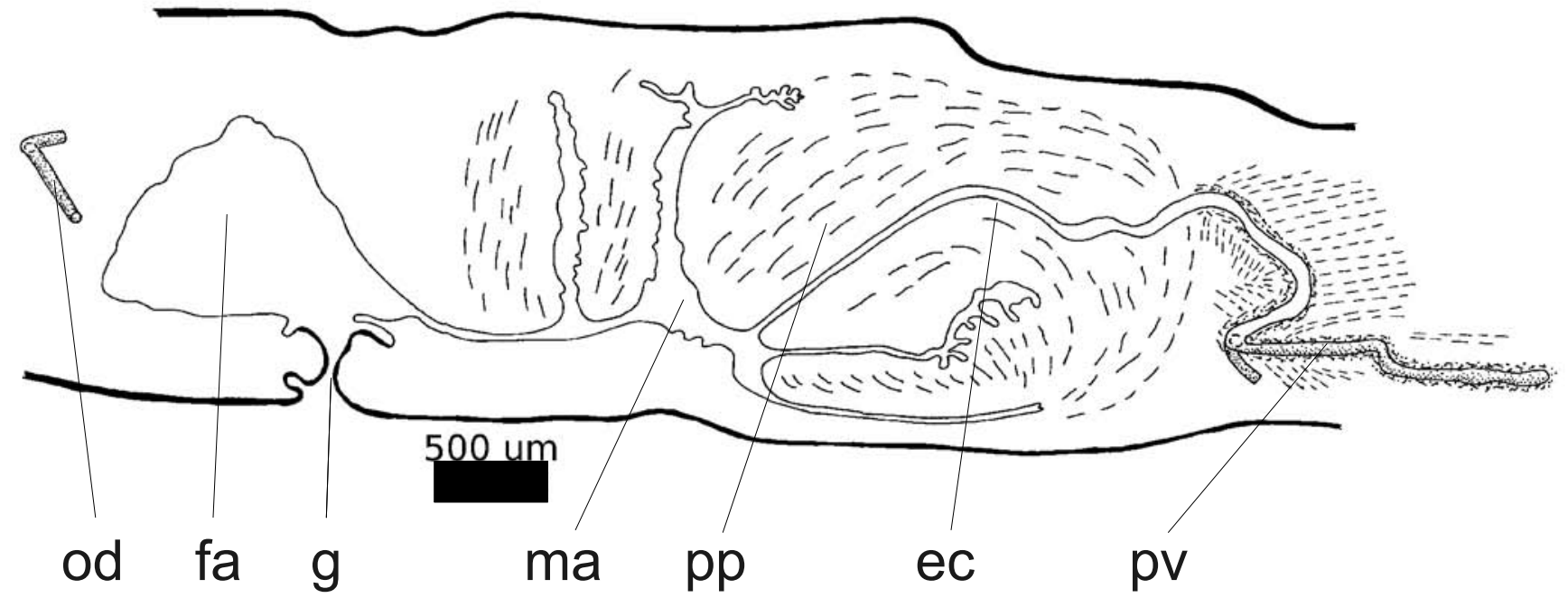

Amaga amagensis (Fuhrmann, 1914). Figure 5. Holotype. A)

Photograph of copulatory apparatus, scale bar: $1 \mathrm{~mm}$. B) Reconstruction of copulatory apparatus, scale bar: $500 \mu \mathrm{m}$. C) Photograph of prostatic vesicle, scale bar: $100 \mu \mathrm{m}$.

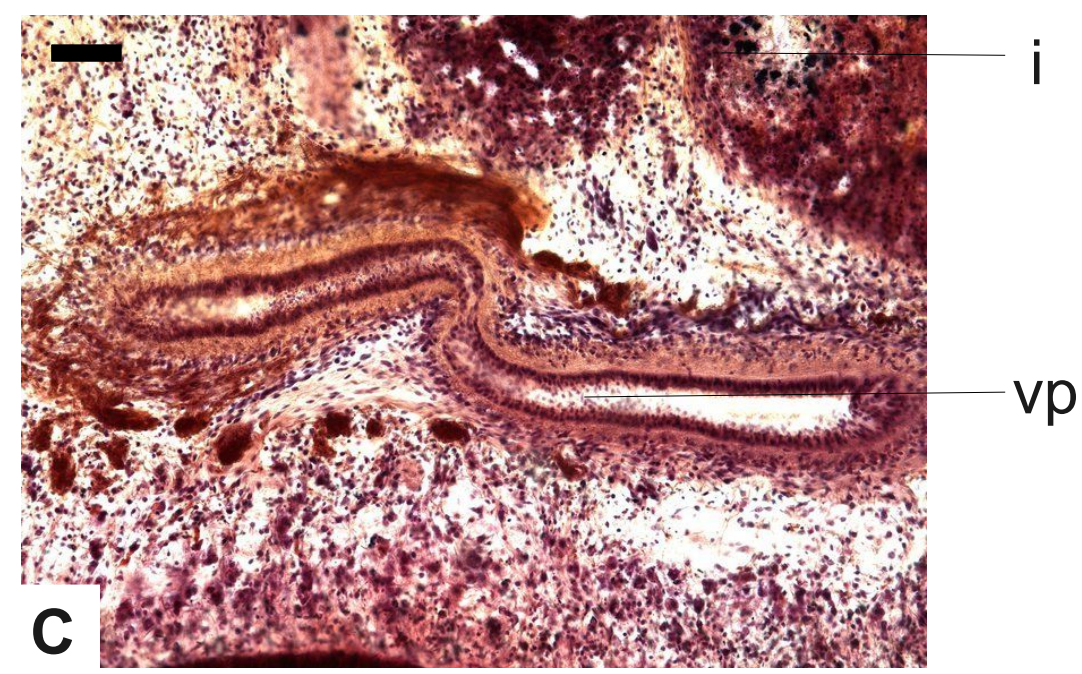




\section{Anzoplana trilineata Winsor, 2006}

\section{EXAMINED MATERIAL}

ZMA KR4-1A: Sagital section of whole body on 13 slides. From a garden in N. Armidale, Australia. $21 \mathrm{March}$ 1990. leg. K. Rohde.

\section{MORPHOLOGY}

External morphology. Creeping sole wide, about $60 \%$ of body width. Eyes pigment-cup type, about $35 \mu \mathrm{m}$ diameter. Eyes multicellular. Sensorial zone extending around anteroventral margin. Sensory pits consist of simple invaginations about $10 \mu \mathrm{m}$ deep.

Sub-epidermic musculature. Tripartite musculature. Cutaneous longitudinal muscles forming distinct bundles, not insunk. Dorsal cutaneous musculature thinner (45 $\mu \mathrm{m}$ thick) than ventral musculature (70 $\mu \mathrm{m}$ thick $) . \mathrm{CMI}=10 \%$.

Sub-epidermal secretions. Dorsal and ventral epithelium of equal height, $17 \mu \mathrm{m}$ thick, both nucleate. Rhabitogen cells underneath dorsal musculature extending dorso-laterally to outer margins of creeping sole.

Mesenchymal musculature. Mesenchymal musculature composed of multiple layers. From dorso to ventral; dorsal double diagonal, transversal supra-intestinal, transversal and longitudinal sub-intestinal, longitudinal sub-neural forming the sub-neural ventral plate, a thin double diagonal located above the sub-epidermal nervous plexus.

Digestive system. Mouth located at posterior fourth of the pouch (Figure 6A-6D). Pharynx cylindrical, horizontal, with dorsal insertion slightly posterior to ventral insertion. Esophagus very short or absent. External pharyngeal musculature with sub-epithelial longitudinal, circular muscles, then mixed circular-longitudinal muscles (Figure 6C). Internal pharyngeal musculature composed sub-epithelial longitudinal, then mixed circular-longitudinal muscles(Figure 6B).

Central nervous system. Organized in flat plate type.

Male reproductive organs. Testes globular in shape, 80-130 $\mu \mathrm{m} \mu \mathrm{m}$ in diameter, located dorsally and ventrally, above and under the intestinal branches. Testes extending from the region of the ovaries to almost the posterior end of the animal. Testes communicate with the efferent ducts common collecting ducts. The Efferent ducts enter separately to the proximal dorsal end of seminal vesicle. Copulatory apparatus situated immediately behind pharyngeal pouch. Copulatory organs complex, with apapillate penis, with paired lateral 
bursae, with eight musculo-glandular organs (Figure 7B). Seminal vesicle lined by ciliated columnar epithelium, divided into two regions: proximal region receives erythrophyll and cyanophyll secretions. Penis papilla absent, penis eversible type. Male atrium largely filled by adenodactyl papillae. At level of mouth efferent ducts form spermiducal vesicles lined by vacuolated cuboidal epithelium.

Female reproductive organs. Ovaries situated anteriorly, taller $(350 \mu \mathrm{m})$ than wider (140 $\mu \mathrm{m})$ (Figure 7C). Ovaries almost half embedded in lateral nerve cords. Ovovitelline ducts arise from dorsal walls of ovaries. Proximal end of each duct expanded to form tuba, with sphincter muscle at point of contact with ovary. Ovovitelline ducts pass ventrally, continue posteriorly along nerve cords to separately enter slightly expanded posterior end of female genital canal. Vitellaria situated between gut diverticula. Vitelline funnels expanded forming resorptive vesicles. Female canals approaching ventrally connecting independently to vagina (Figure 7A). Shell glands opening to glandular canal. Female atrium with tall secretive epithelia. Common muscular coat inconspicuous. 

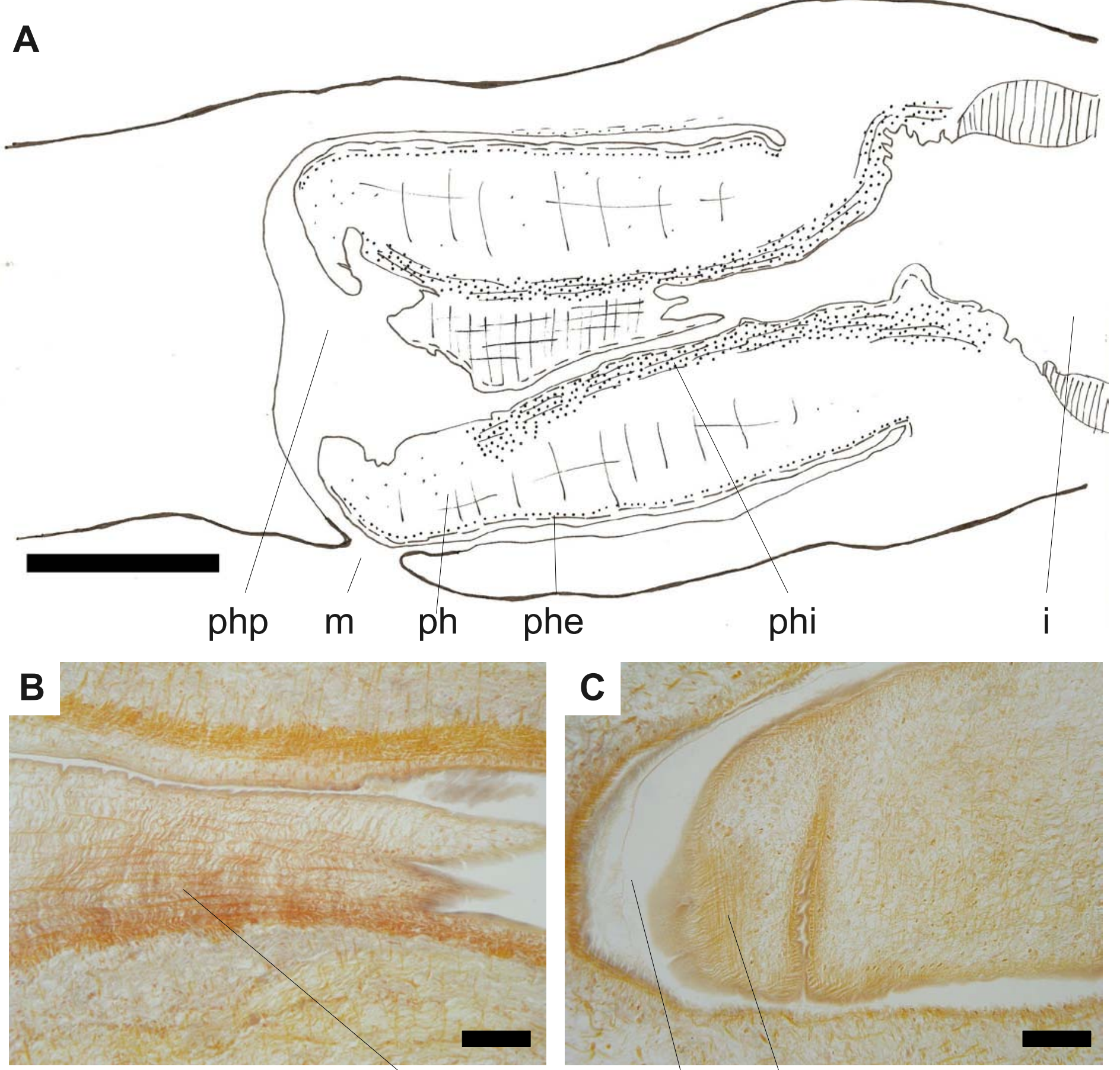

\section{Anzoplana trilineata}

phi

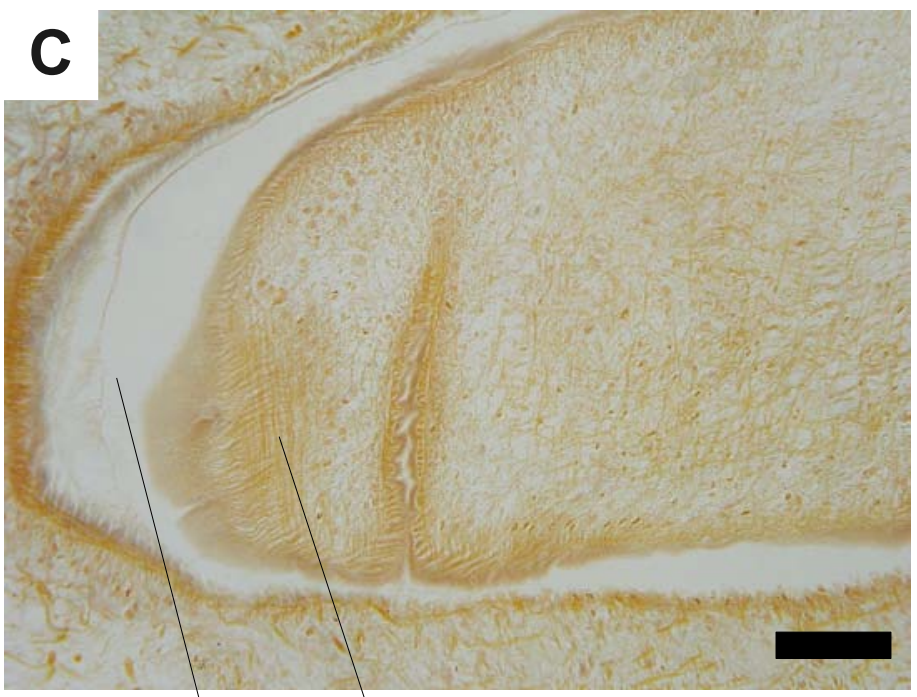

\section{Winsor, 2006. Figure 6.}

Specimen KR4-1A. A)

Reconstruction of pharynx scale bar: $250 \mu \mathrm{m}$. B)

Photograph of internal pharynx musculature, scale bar: $100 \mu \mathrm{m} . \mathbf{C )}$ Photograph of external pharynx musculature, scale bar: $100 \mu \mathrm{m}$. D) Photograph of pharynx, php phe

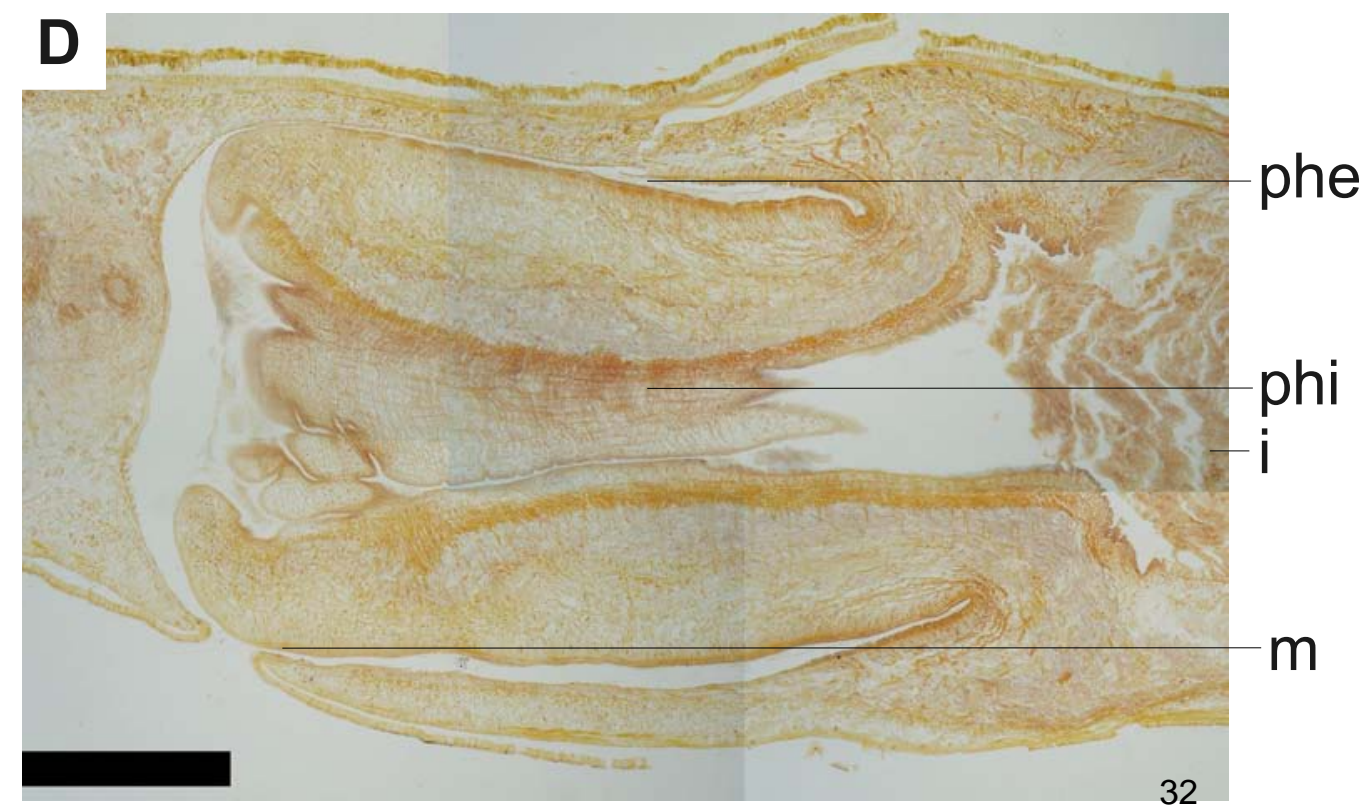


A
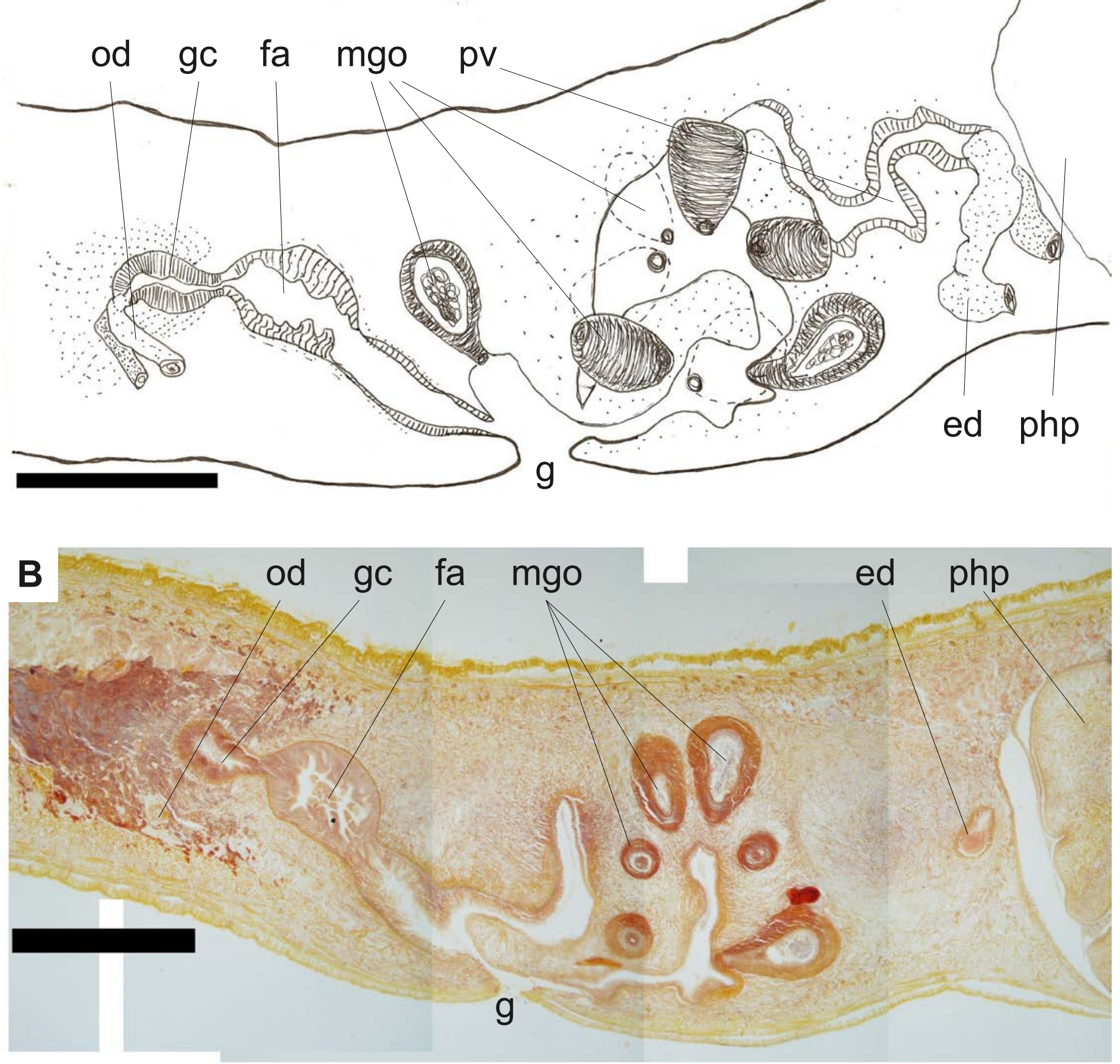

C

od

Anzoplana trilineata Winsor, 2006. Figure 7.

OV Specimen KR4-1A. A) Reconstruction of copulatory apparatus, scale bar: $250 \mu \mathrm{m}$. B)

od Photograph of copulatory apparatus bar: 250

SC $\quad 100 \mu \mathrm{m}$. 


\section{Bipalium kewense Moseley, 1878}

\section{SYNONYMS}

Bipalium manubriatum n. sp. Sharp, 1891.

Sphyrocephalus kewensis: Hallez, 1893.

Placocephalus kewensis: von Graff, 1896.

\section{EXAMINED MATERIAL}

NHMW 2823: (Graff $n^{\circ} 239$ ) Frontal sections of anterior part, transversal sections of pre-pharynx, sagittal sections of pharynx, sagittal sections of copulatory apparatus, frontal slides of posterior part on 369 slides.

\section{MORPHOLOGY}

External morphology. The creeping sole is approximately $23 \%$ of body width. Sensory pits located anteriorly in a submarginal zone. Multiple eyes surrounding anterior tip. Eyes monolobulated.

Sub-epidermal musculature. Bipartite layered musculature. Weak longitudinal insunk into mesenchym.

Sub-epidermal secretions. Dorsal epithelium thicker than ventral.

Mesenchymal musculature. Mesenchymal musculature composed mainly of longitudinal, transversal and dorso-ventral fibers. Mesenchymal longitudinal fibers disposed in a ring zone (Figure 8B). Compact longitudinal fiber muscles a form ventral plate lying underneath the nerve chords and extending about half the body width.. These muscle plates are intersected by transversal and oblique isolated muscle fibers. Longitudinal muscle bundles intermingle with transverse muscles dorsal and ventrally and form a ring zone around the intestines. Small bundles of longitudinal muscles are present in the sub and supraintestinal regions.

Digestive system. Collar shaped pharynx, highly plicate with dorsal insertion in the posterior third of the pharyngeal pouch. Esophagus absent. The pharyngeal wall consists of three layers; outer musculature consists of longitudinal sub-epithelial layer, followed by a middle layer of circular fibers, and an innermost layer of longitudinal muscle fibers.

Central nervous system. Disposed as two ventral nerve chords.

Male reproductive organs. Testes ventral extending from the behind the ovaries to the root of the pharynx in an uni-serial distribution, between ovaries and root of pharynx. 
Efferent ducts lay along the lateral margins of the nerve chords. They communicate with the testes via short thin testicular funnel. Irregular shaped prostatic vesicle lined with a highly rugose, nucleate, columnar epithelium packed with erythrophyll secretions. The penis bulb is made up by a thick coat of loosely arranged intermingled circular and longitudinal fibers that pack the prostatic vesicle and the a thin penial projection. Penis papilla, male atrium and copulatory canal are surrounded entally by a thin layer of circular muscle. The penis papilla is covered by a flattened, nucleate cuboidal epithelium. The genital pad is highly muscular and separates the male and female atriums (Figure 8A). It is covered by a-nucleate, flattened epithelium pierced by numerous ducts of acidophyll glands.

Female reproductive organs. Ovaries: $240 \mu \mathrm{m}$ long and $190 \mu \mathrm{m}$ high, immediately dorsal to nerve chords and at a distance from anterior end. The ovovitelline ducts emerge from the ventro-lateral walls of the ovaries. Ovovitelline ducts are located above the nerve chords and and internal to the efferent ducts. The run backwards and ascend after the gonopore. The ovovitelline approach the female glandular canal separately. Ovovitelline do not receive shell glands. The female copulatory organs are composed of a thin and long vertical vagina that continues as a horizontal glandular canal, in the posterior end of which the ovovitelline ducts open. Both the female and male atriums are replaced by a muscular pad which that protrudes the gonopore. The glandular canal is composed of tall ciliated rugose columnar pseudostratified epithelium. The vagina epithelium is similar but thinner. Secretions derived from the posteriorly located shell glands open into the hinder middle part of the glandular canal. 


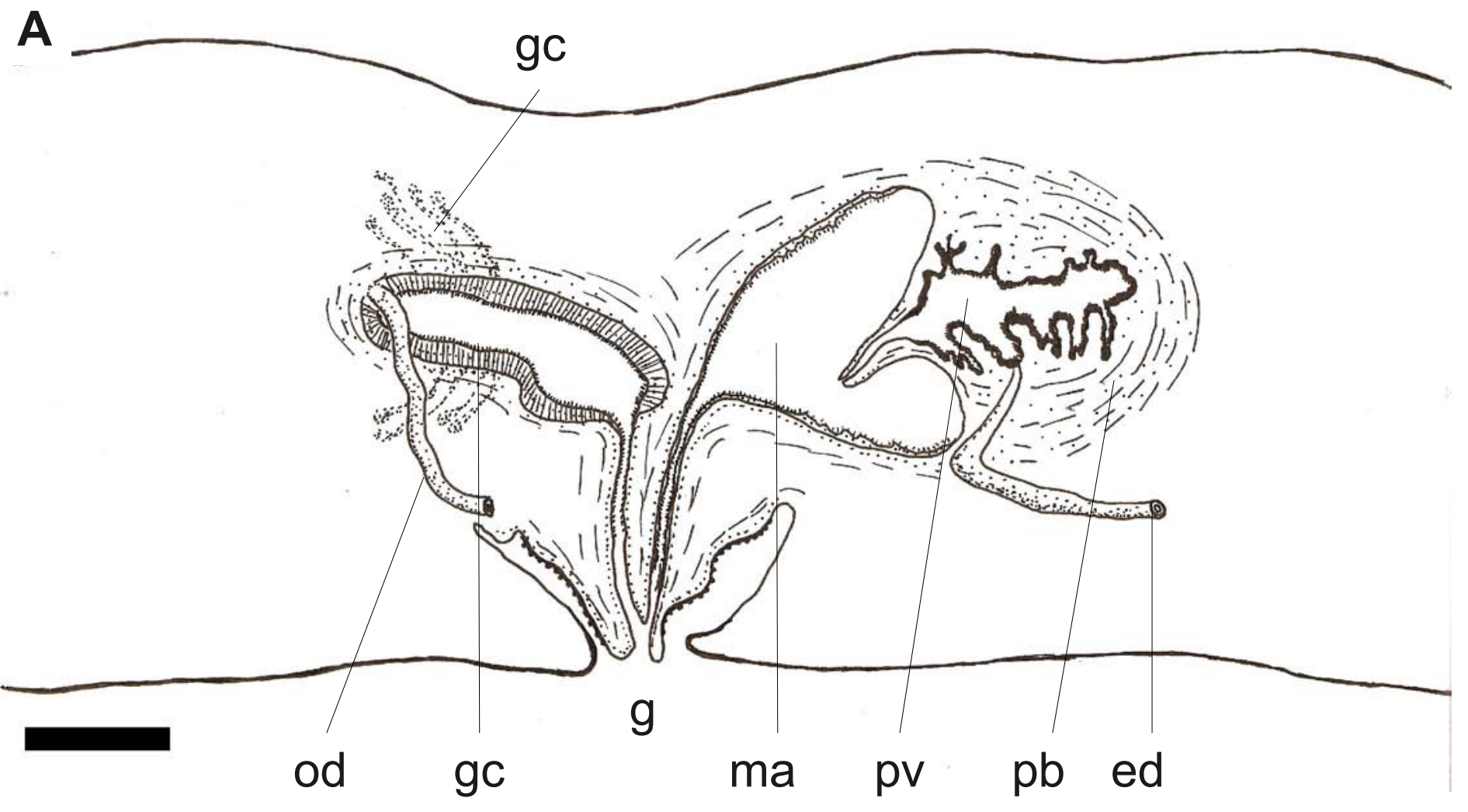

B

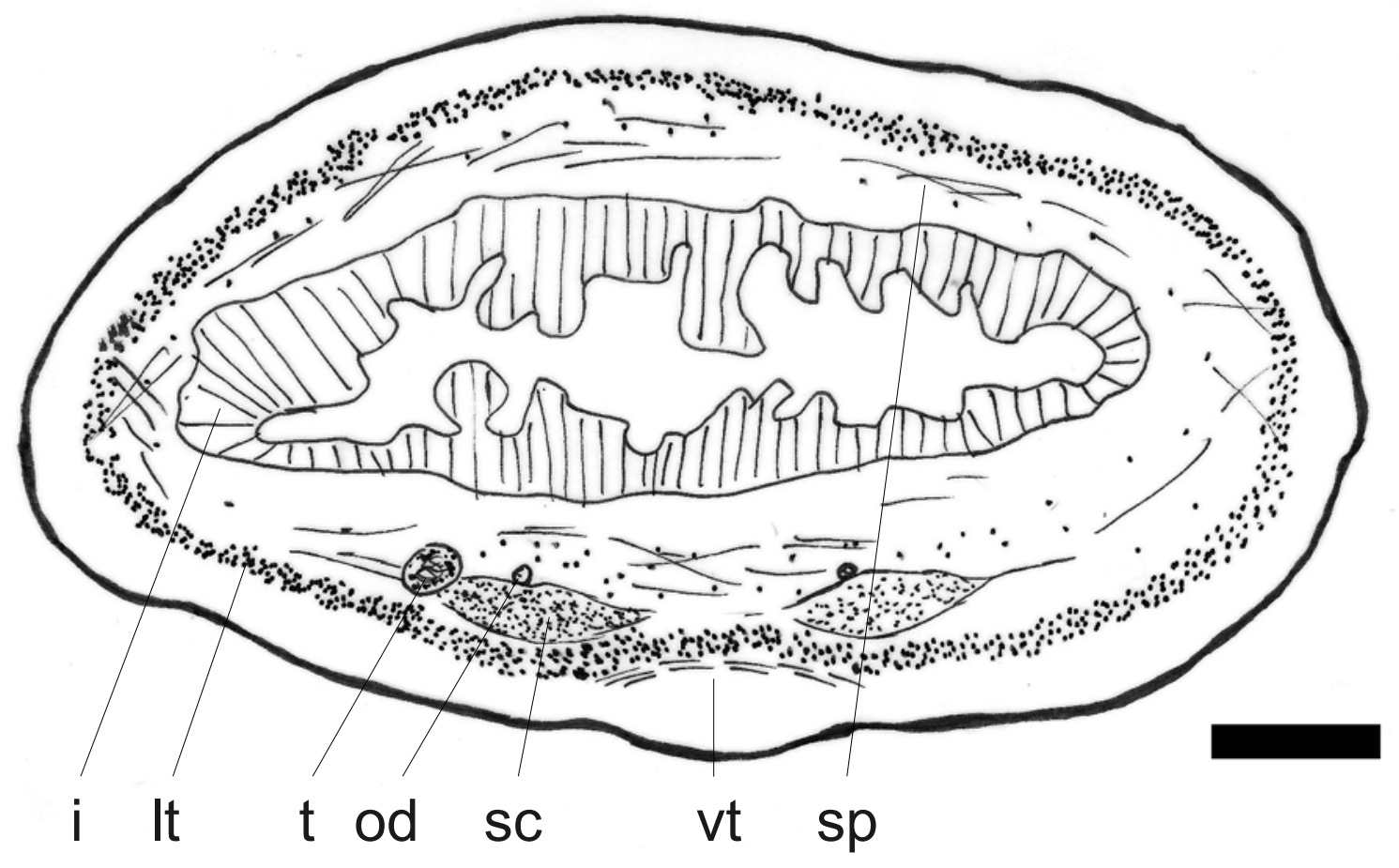

Bipalium kewense Moseley, 1878. Figure 8. A) Reconstruction of copulatory apparatus of specimen NHMW 2823, scale bar: $500 \mu \mathrm{m}$. B) Reconstruction of Pre-pharyngeal region, redrawn from Winsor (1983), scale bar: $500 \mu \mathrm{m}$. 


\section{Cephaloflexa bergi (von Graff, 1899)}

\section{SYNONYMS}

Geoplana bergi von Graff, 1899

Choeradoplana iheringi Schirch, 1929

Geoplana meixneri Riester, 1938

Geoplana bergi Marcus, 1951

Notogynaphallia bergi Ogren \& Kawakatsu, 1990

Notogynaphallia meixneri Ogren \& Kawakatsu, 1990

\section{EXAMINED MATERIAL}

IPP 880: Transversal sections of anterior part 1 on 3 slides. Transversal sections of anterior part 2 on 5 slides. Transversal sections of anterior part 3 on 13 slides. Transversal sections of pre-pharyngeal region 1 on 8 slides. Transversal sections of pre-pharyngeal region 2 on 6 slides. IPP 881: Transversal sections of anterior part 1 on 4 slides. IPP 677: Transversal sections of pre-pharyngeal region on 5 slides. Sagittal section of pharynx and copulatory apparatus on 29 slides. IPP 911: Sagittal sections of copulatory apparatus on 19 slides.

FCB 2165: Sagittal sections of copulatory apparatus on 29 slides. Parque estadual Desengano, RJ, Brazil.

\section{MORPHOLOGY}

External morphology. Flat body (Figure 10A, 10B). Creeping sole about $83-88 \%$ body width. Eyes irregularly uniserial, absent on anterior tip. Sensory pits composed of simple invaginations, about $30 \mu \mathrm{m}$ deep, absent on anterior tip.

Sub-epidermal musculature. Tripartite sub-epidermal musculature. Longitudinal musculature packed in bundles (Figure 10C). Dorsal longitudinal musculature thicker than ventral cutaneous muscle. Sub-epidermal musculature in the head different arrangement to that of pre-pharyngeal body region; ventral longitudinal sub-epidermal layer becomes thicker in anterior direction, grouping to form a cephalic retractor muscle of lenticular shape in crosssection (Figure 9A, 9B, 9C).

Sub-epidermic secretions. Mainly basophilic and xanthophyll secretions in the prepharyngeal region, openings of erythrophil and rhabditogen cells throughout dorsal and lateral body regions, scarce on creeping sole. Glandular margin absent. Rhabditogen cells placed slightly above transversal sub-neural, between the nervous system and the cutaneous musculature. 
Mesenchymal musculature. Mesenchymal musculature composed of three main layers: a dorsal diagonal layer with decussate fibers, a supra-intestinal transverse layer, and a subintestinal transversal layer; sub-intestinal layer slightly more developed than supra-intestinal layer. Mesenchymal musculature more spread in the cephalic region with the emergence of fourth layer, a transversal sub-neural, placed underneath the nervous system. Longitudinal mesenchymal musculature absent.

Digestive system. Mouth located at end of middle third of pharyngeal cavity (Figure 11A). Pharynx cylindrical, with dorsal insertion posteriorly displaced. Esophagus present, about $25 \%$ of pharynx length, with folded walls (Figure 11B). Epithelium cubic ciliated. Esophagus musculature of a circular layer intermixed with longitudinal fibers. Musculature of pharyngeal pouch composed of circular and longitudinal muscle fibers. External pharynx musculature (Figure 11C) consists of longitudinal sub-epithelial layer, followed by a layer with crossed longitudinal and circular fibers. Internal pharynx musculature (Figure 11D) consists of thick sub-epithelial circular layer followed a layer of circular and longitudinal fibers, with some inserted radial fibers. External and internal epithelia densely ciliated. Basophilic, xanthophyll and erythrophyll secretory cells open through distal region of pharynx.

Central nervous system. Nervous system organized in flat plate type brain.

Male reproductive organs. Testes located dorsally, placed underneath supra-intestinal mesenchymal layer (Figure 10D), extending between ovaries and root of pharynx. Each testicle communicated with the efferent duct through a thin dorso-ventral channel. Efferent ducts dorsal to nerve plate; increased in diameter near prostatic vesicle and turn anteriorly and sagittally and open the anterior-most part of the prostatic vesicle. Efferent ducts with ciliated epithelium. Efferent duct musculature composed of a layer of circular muscle fibers (15 $\mu \mathrm{m}$ thick). The prostatic vesicle with paired branches directed anteriorly, then curved postero-dorsally and subsequently joined to form an unpaired branch; the latter downwards directed, except for distal part, which is postero-dorsally curved. Prostatic vesicle line with columnar ciliated epithelium (Figure 12D). Prostatic vesicle with two regions; anteriorly with xanthophyll and basophilic secretions, and posteriorly erythrophil, and xanthophyll. Prostatic vesicle musculature composed mainly of circular fibers. Male atrium long (Figure 12A), divided into two regions, proximal half with abundant small folds (Figure 12B) and openings of xanthophyll secretory cells, and distal half with large folds and openings of xanthophyll and basophyll secretory cells; towards female atrium, openings of basophyll cells more abundant, xanthophyll cells scarcer. Epithelium cubic non-ciliated. Ejaculatory duct absent. Ejaculatory 
cavity anterior to male atrium and dorsal to distal portion of prostatic vesicle. Ejaculatory cavity epithelium columnar ciliated, composed of circular muscle fibers.

Female reproductive organs. Ovaries elongated, about $160 \mu \mathrm{m}$ long and $25 \mu \mathrm{m}$ tall, located dorsally to nerve plate. Ovovitelline ducts run beneath the transversal sub-intestinal and ventral to efferent ducts; emerge dorsally from median third of each ovary. The ovoviteline ducts ascend at the level of gonopore. Last portion of oviducts pierced with shell glands. Vagina consists of a short and wide cavity, directed dorso-anteriorly and communicating with the posterior end of female atrium (Figure 12C). Epithelium pseudostratified, non-ciliated. Female atrium elongated, lined with ciliated columnar epithelium, ciliated. Musculature of female atrium composed of circular sub-epithelial followed by longitudinal. Female atrium length about $50 \%$ of male atrium. Common muscle coat wrapping distal portion of efferent ducts, prostatic vesicle, male and female atria and vagina enveloped by muscle coat. 
A
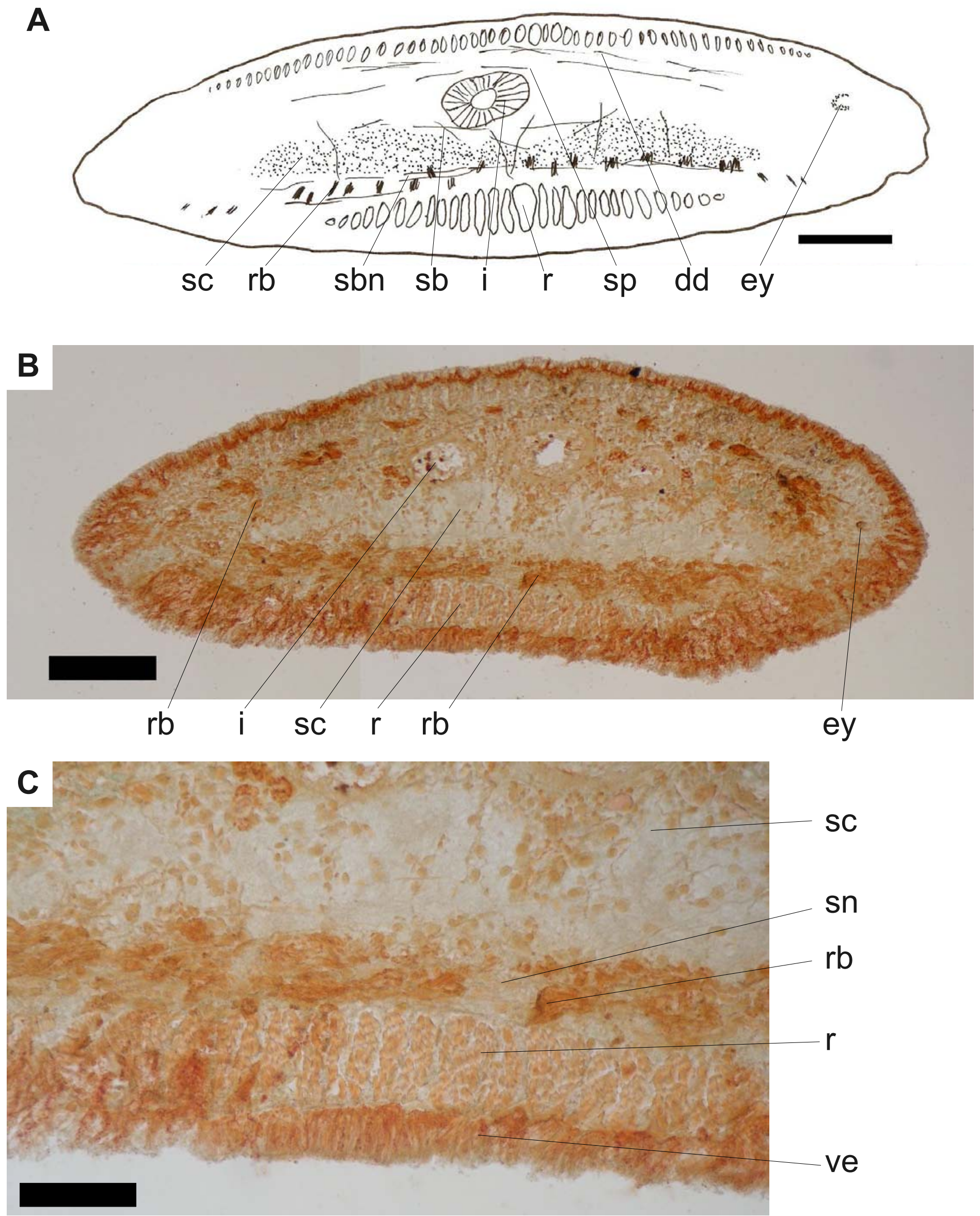

Cephaloflexa bergi (von Graff, 1899). Figure 9. A) Reconstruction of section of cephalic region of specimen IPP 880, scale bar: $500 \mu \mathrm{m}$. B) Photograph of section of section of cephalic region of specimen IPP 881, scale bar: $100 \mu \mathrm{m}$. C) Photograph of cephalic retractor muscle of specimen IPP 881, scale bar: $50 \mu \mathrm{m}$. 
A
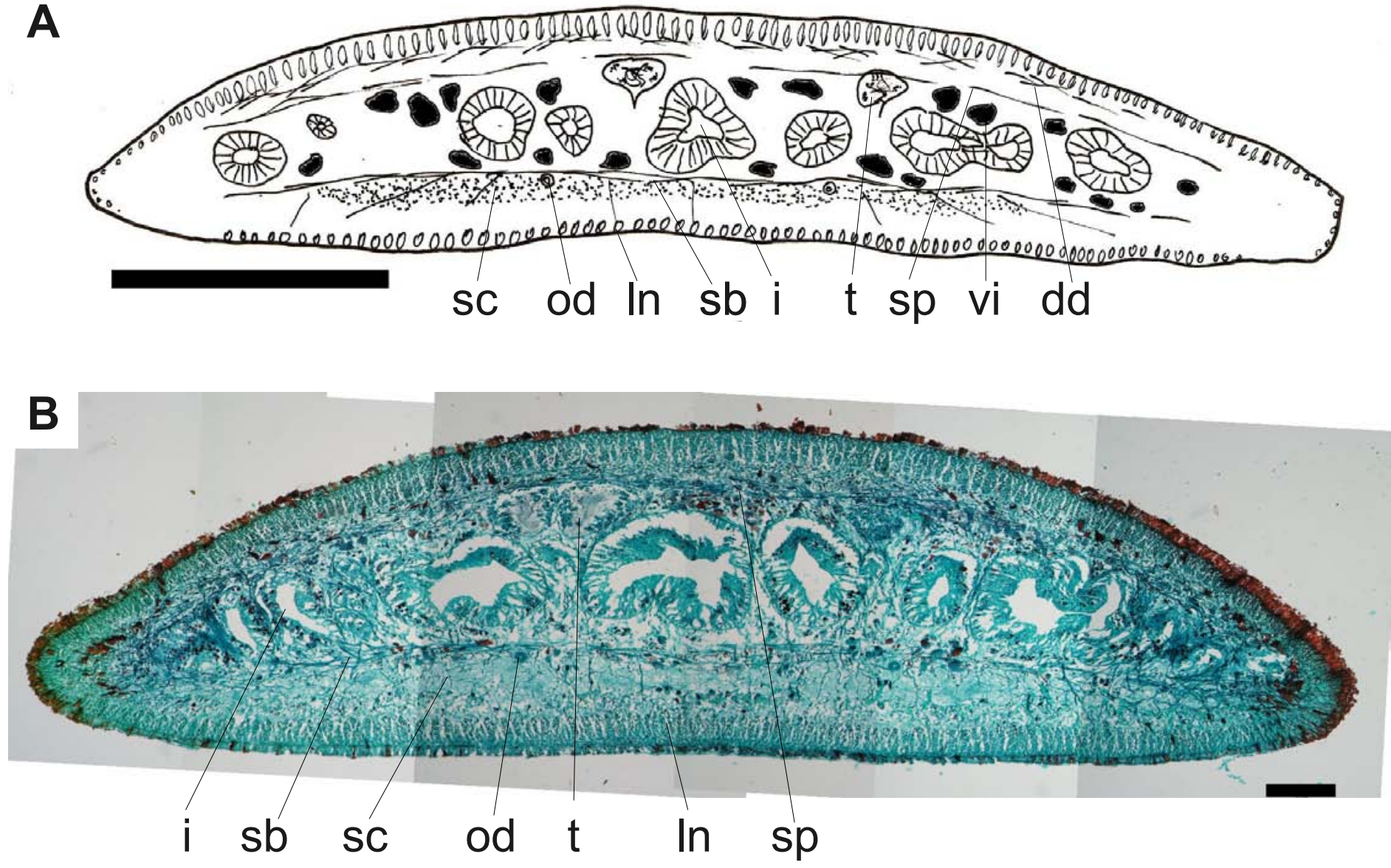

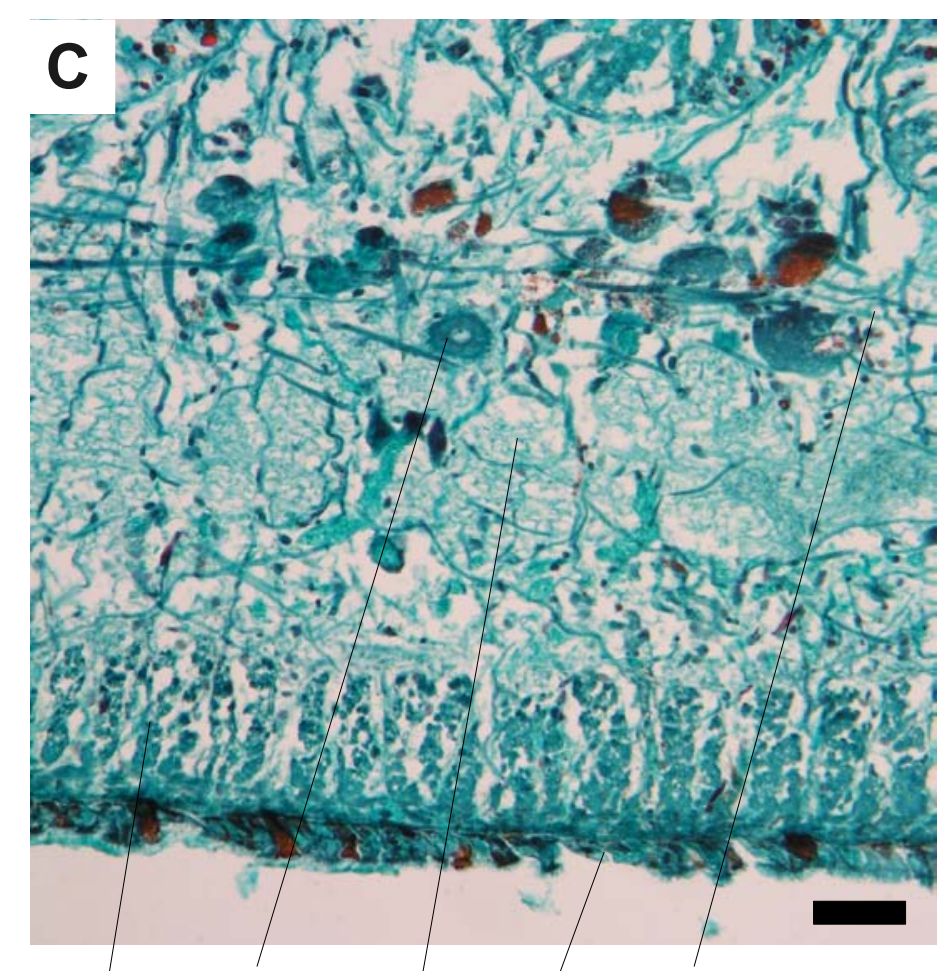

In od sc ve sb

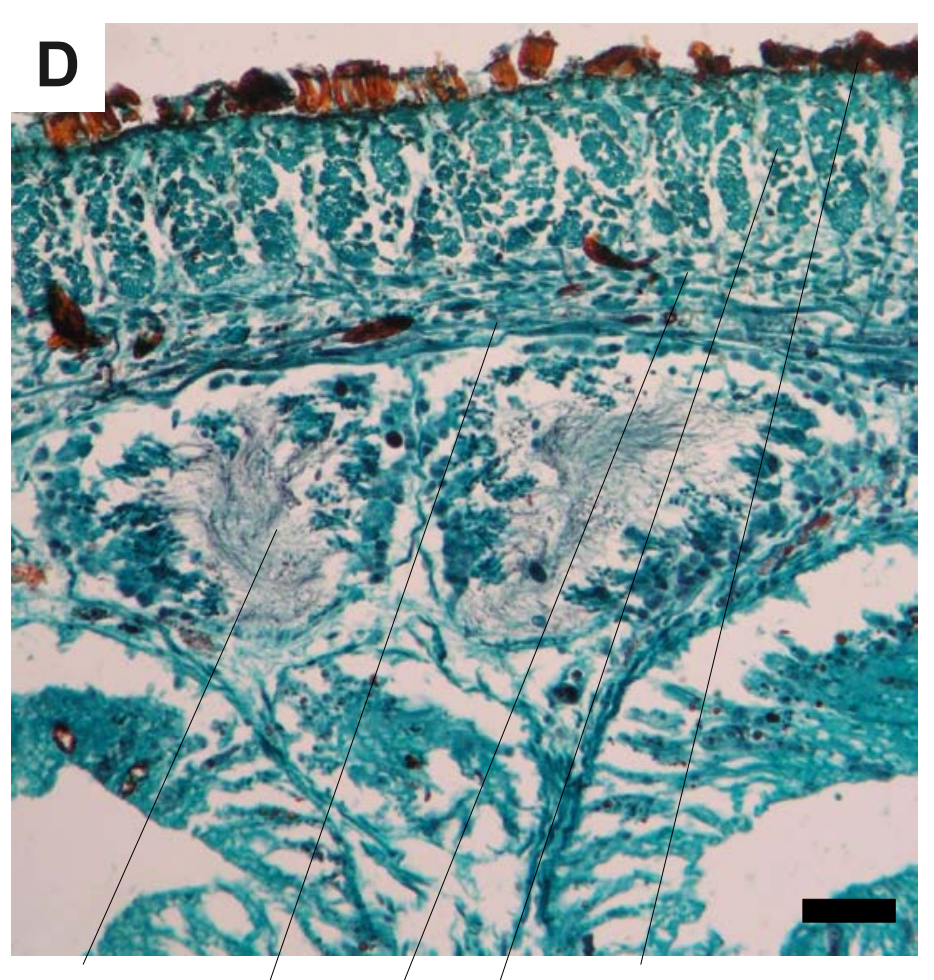

t $\quad s p$ dd In de

Cephaloflexa bergi (von Graff, 1899). Figure 10. A) Reconstruction of section pre-pharyngeal region of specimen IPP 880, scale bar: $1250 \mu \mathrm{m}$. B) Photograph of section of cephalic region of specimen IPP 677, scale bar: $100 \mu \mathrm{m}$. C) Photograph of ventral sub-epidermic musculature of specimen IPP 677, scale bar: $50 \mu \mathrm{m}$. D) Photograph of dorsal sub-epidermic musculature of specimen IPP 677 , scale bar: $50 \mu \mathrm{m}$. 

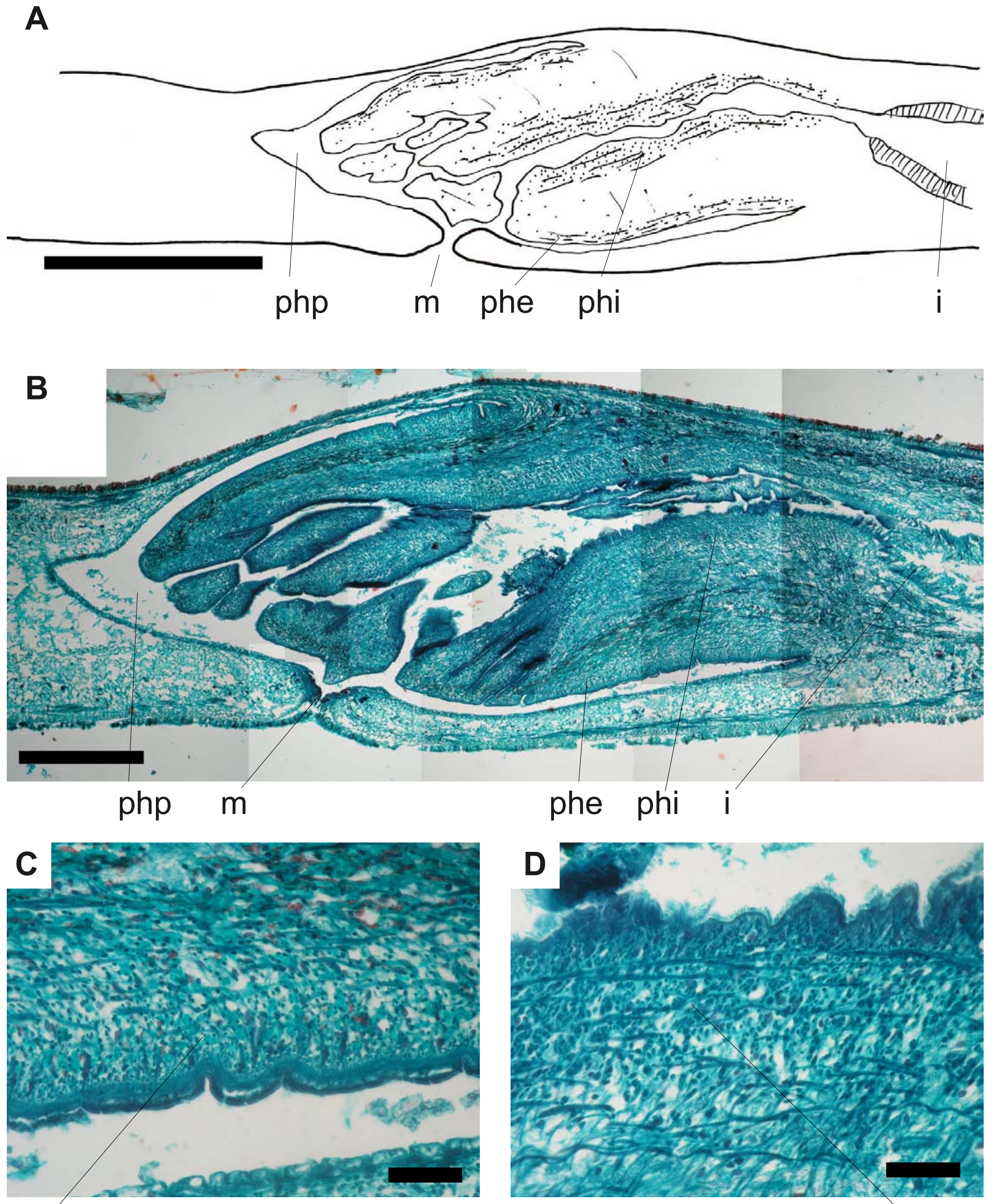

phe

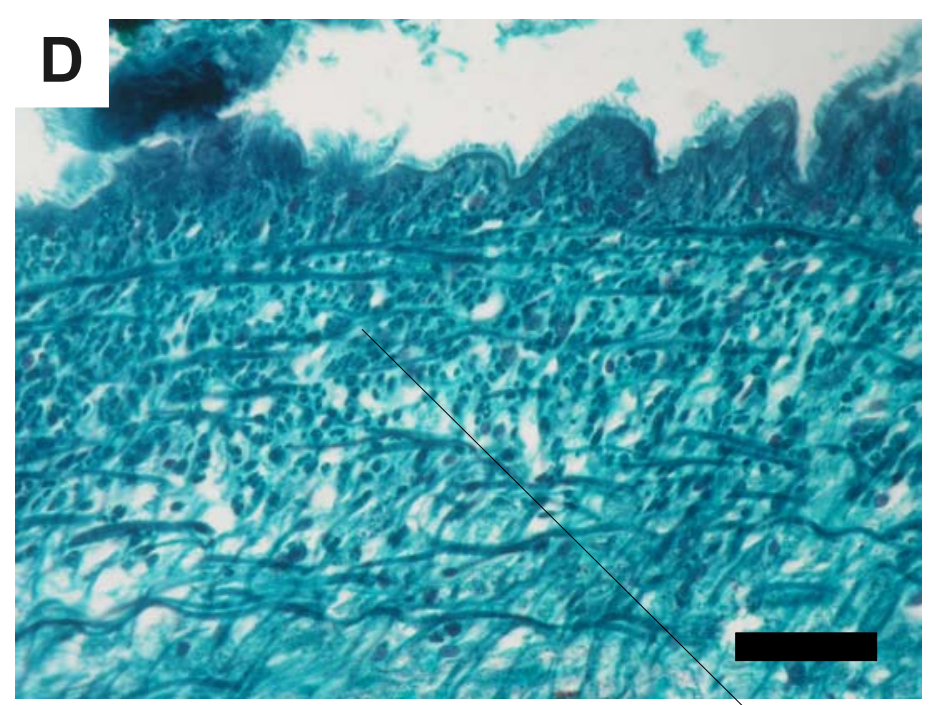

phi

Cephaloflexa bergi (von Graff, 1899). Figure 11. A) Reconstruction of the pharynx of specimen IPP 677, scale bar: $1250 \mu \mathrm{m}$. B) Photograph of the pharynx of specimenIPP 677, scale bar: 500 $\mu \mathrm{m}$. C) Photograph of external pharynx musculature of specimen IPP 677, scale bar: $100 \mu \mathrm{m}$. D) Photograph of internal pharynx musculature of specimen IPP 677, scale bar: $100 \mu \mathrm{m}$. 

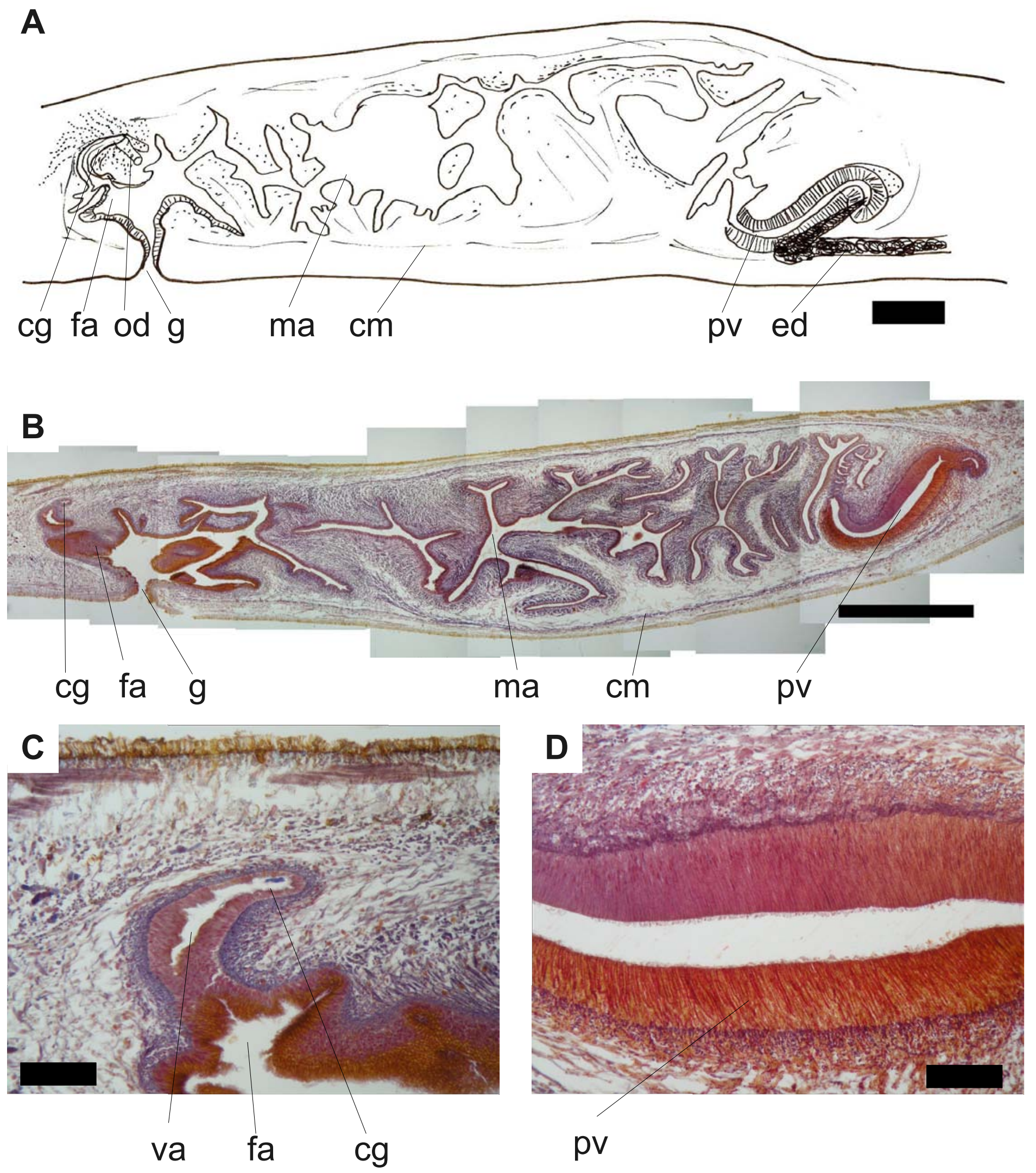

Cephaloflexa bergi (von Graff, 1899). Figure 12. A) Reconstruction of the copulatory apparatus of specimen FCB2165, scale bar: $500 \mu \mathrm{m}$. B) Photograph of copulatory apparatus of specimen IPP 911, scale bar: $1000 \mu \mathrm{m}$. C) Photograph of the vagina of specimen IPP 911, scale bar: 100 $\mu \mathrm{m}$. D) Photograph of the prostatic vesicle of specimen IPP 911, scale bar: $100 \mu \mathrm{m}$. 


\section{Choeradoplana iheringi von Graff, 1899}

\section{EXAMINED MATERIAL}

EMF Ch. Iheringi 1.VIII.1953: Transversal sections of pre-pharynx in 2 slides. Sagittal sections of Anterior part in 4 slides. EMF Ch. Iheringi 1: Sagittal sections of copulatory apparatus in 2 slides. Sagittal sections of pharynx in slide. EMF Ch. Iheringi 2: transversal sections of anterior part in 3 slides.

\section{MORPHOLOGY}

External morphology. Creeping sole wide, about $81-84 \%$ of body width. Eyes skirting anterior part, absent on anterior tip. Eyes extending backwards in simple row then pluriserialy extending to posterior end.

Sensory pits composed of simple invaginations, arranged in a single row; sensory pits absent in anterior tip.

Sub-epidermal musculature. Tripartite musculature. Longitudinal muscle layer packed in bundles (Figure 14C). Longitudinal layer ventrally ventrally insunk (Figure 14D). Longitudinal ventral layer forming cephalic retractor muscle in triangle shape in cross section (Figure 13A, 13B). Dorsal longitudinal thicker than ventral (Figure 14B).

Sub-epidermal secretions. Glandular ridge absent. Two glandular cushions present in the anterior tip, separated by a median groove (Figure 13C).

Mesenchymal musculature. Mesenchymal musculature composed of three main layers. Dorsal double diagonal, supra-intestinal transversal and sub-intestinal transversal. Mesenchymal longitudinal musculature absent. Transversal sub-neural and present only in cephalic region. In the cephalic region the transversal supra-intestinal together with dorsoventral fibers form an interwoven muscle arrangement (Figure 13D).

Digestive system. Bell shaped pharynx (Figure 15A, 15B). External pharynx musculature (Figure 15D) composed of a thin longitudinal sub-epithelial layer and an inner circular, intermixed at some points with longitudinal fibers. Internal pharynx musculature (Figure 15C) composed of a compact circular layer intermixed with longitudinal fibers.

Central nervous system. Present as a flat plate.

Male reproductive system. Testes dorsal, placed underneath supra-intestinal transversal mesenchymal muscle layer (Figure 14A). Anterior most testes located slightly posterior to ovaries. Posterior most testes located at pharynx insertion. Distributed in up to four rows on each side. Each testicle communicated with the efferent duct through a thin 
dorso-ventral channel. Penis papilla absent (Figure 16A). Prostatic vesicle intra-bulbar (Figure 16D), composed of two regions, an proximal portion of tubular shape and a distal portion of irregular shape. Efferent ducts communicate ventrally the prostatic vesicle. Ejaculatory duct absent. The distal portion of the prostatic vesicle communicates directly and through a broad opening with the male atrium. Male atrium long and greatly folded. Male atrium musculature composed of a sub-epithelial circular layer followed by a longitudinal layer.

Female reproductive system. Ovaries placed around $12 \%$ body length behind the anterior tip. Ovaries globular and placed above the nervous plexus. The oviducts emerge externally from the anterior part of the ovaries, and extend backwards above the nervous plexus. Posterior to the gonopore, oviducts rise and fuse to form a long common glandular duct, which runs dorsally to the female atrium and opens to the vagina. Vagina located dorsally (Figure 16B). Female atrium long, about half the length of the female atrium. Female atrium not richly folded as male atrium. Shell glands entering through last portion of the oviducts and the common glandular duct (Figure 16C). 
A
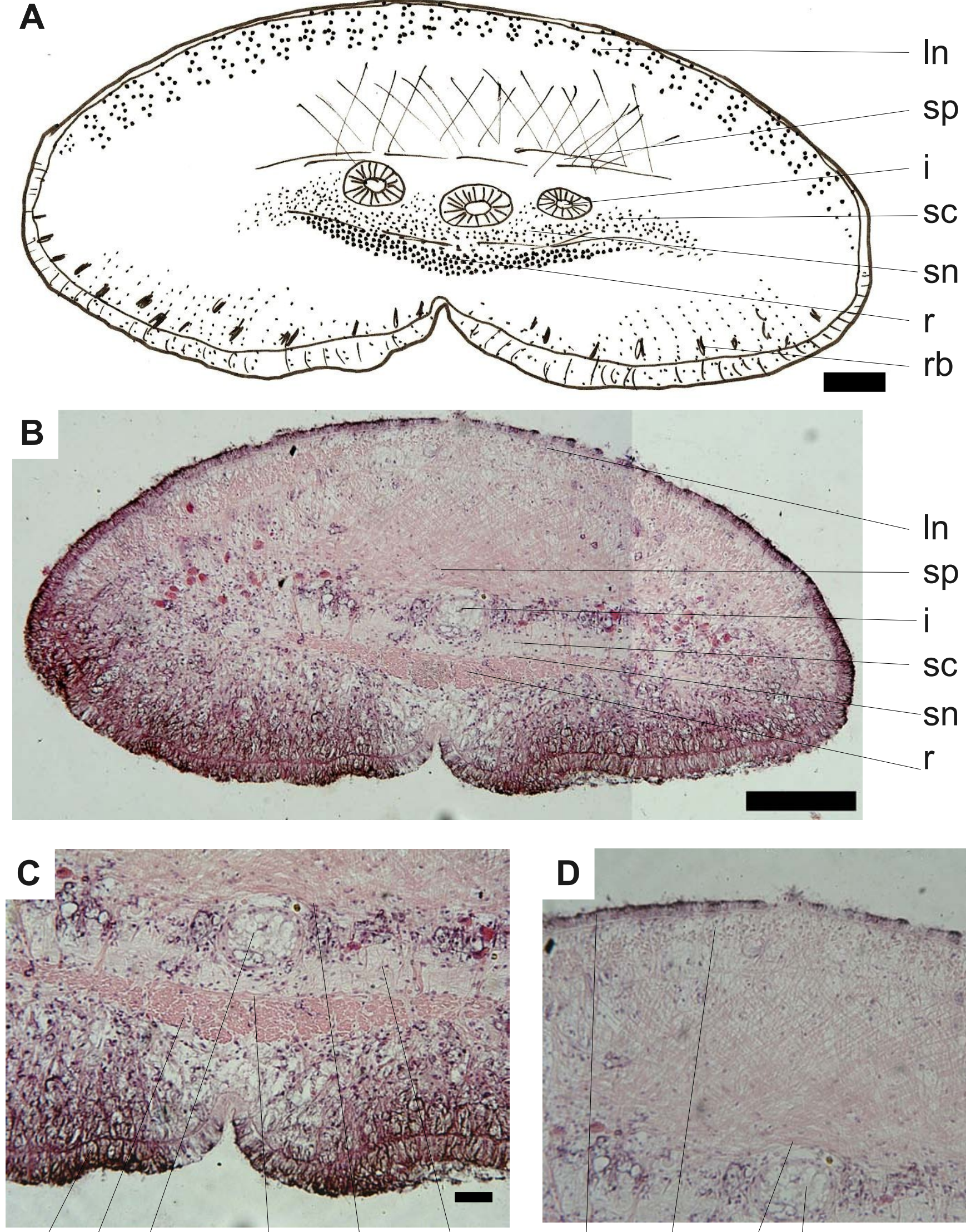

ve $r$ i sn sp sc de In sp i

Choeradoplana iheringi von Graff, 1899. Figure 13. Specimen EMF Ch. Iheringi 2. A)

Reconstruction of section of anterior region, scale bar: $100 \mu \mathrm{m}$. B) Photograph of transversal section of anterior region, scale bar: $200 \mu \mathrm{m}$. C) Photograph of cephalic retractor muscle, scale bar: $50 \mu \mathrm{m}$. D) Photograph dorsal sub-epidermic musculature of anterior region, scale bar: $50 \mu \mathrm{m}$. 
A
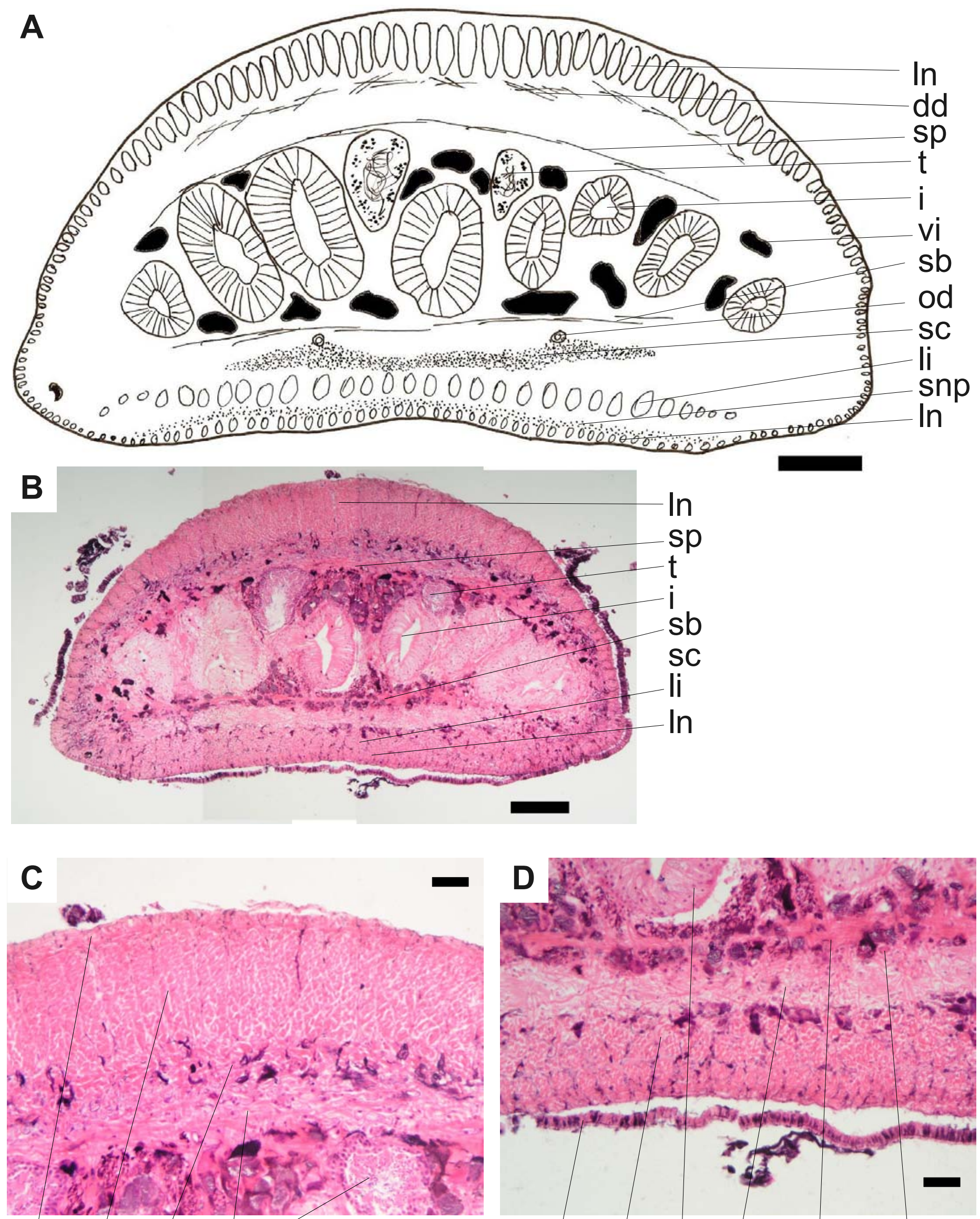

de $\ln$ dd $\mathrm{sp} t$

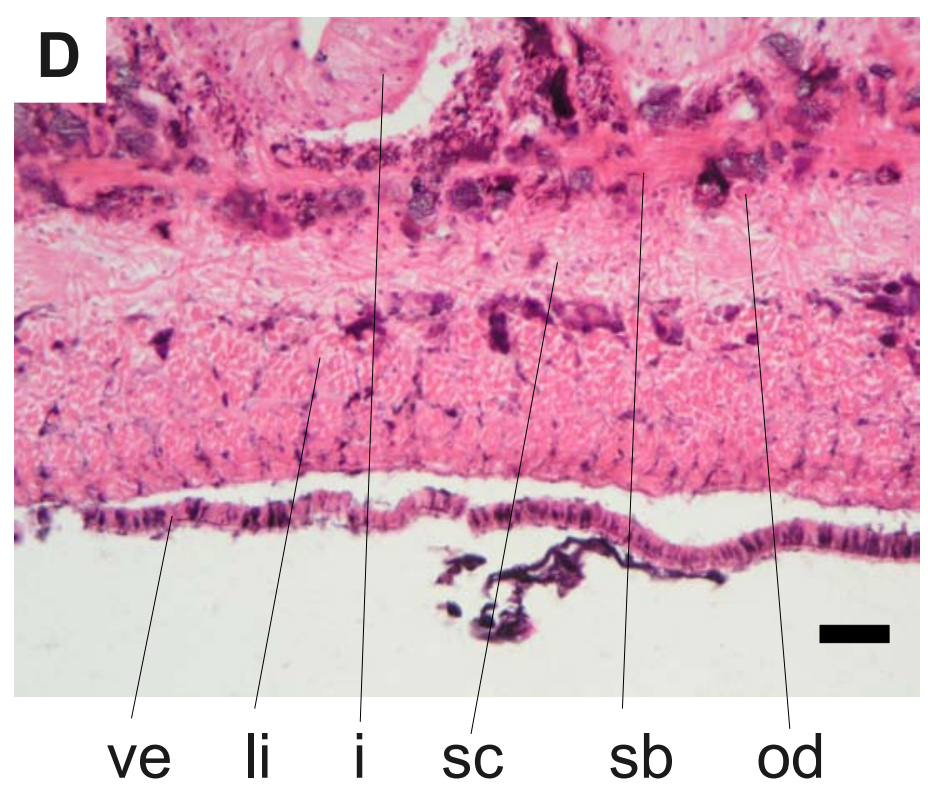

Choeradoplana iheringi von Graff, 1899. Figure 14. Specimen EMF 1.VIII.1953. A)

Reconstruction of section of pre-pharyngeal region, scale bar: $200 \mu \mathrm{m}$. B) Photograph of section of pre-pharyngeal, scale bar: $200 \mu \mathrm{m}$. C) Photograph of dorsal sub-epidermic musculature, scale bar: $50 \mu \mathrm{m}$. D) Photograph ventral sub-epidermic musculature, scale bar: $50 \mu \mathrm{m}$. 
A
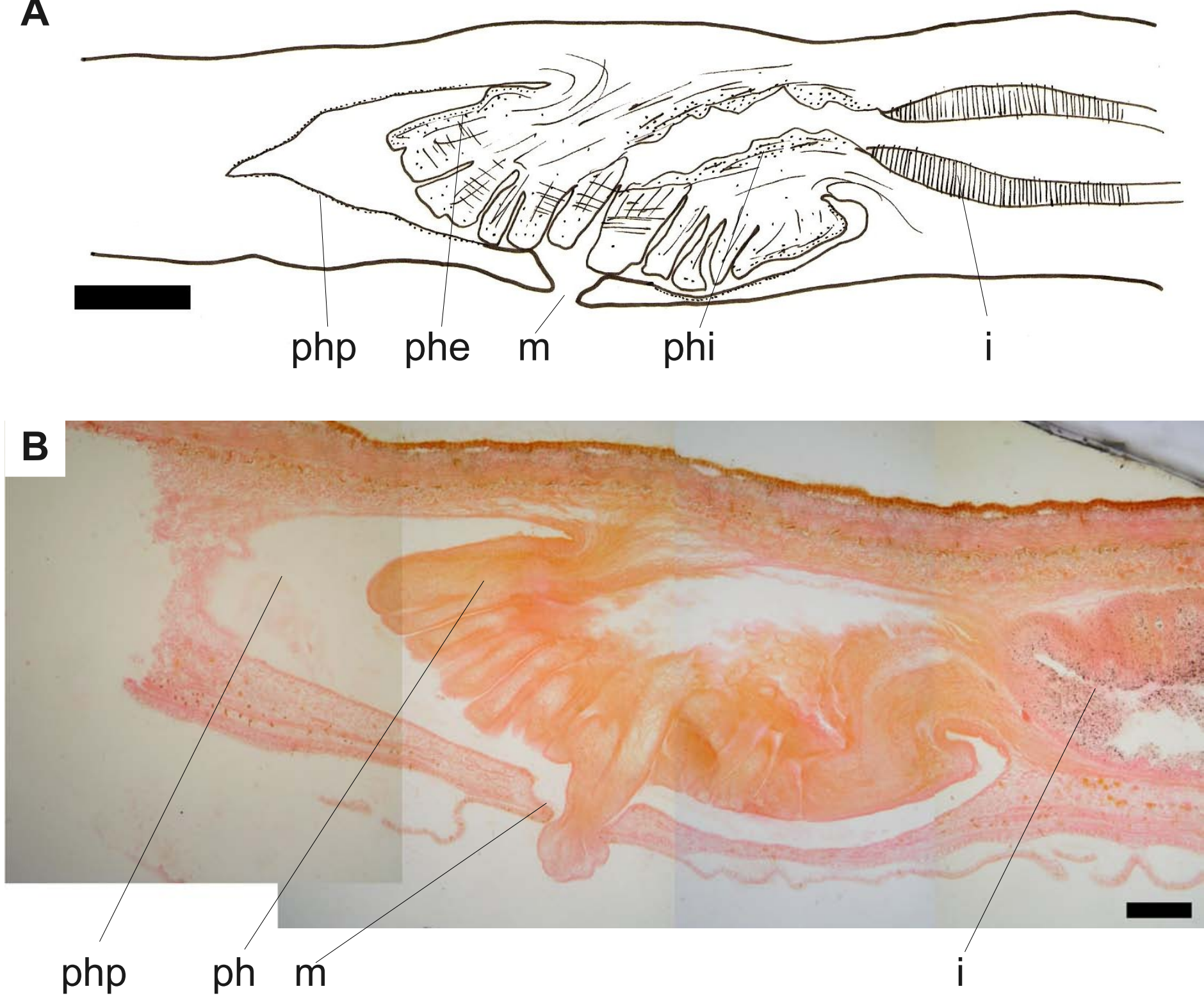

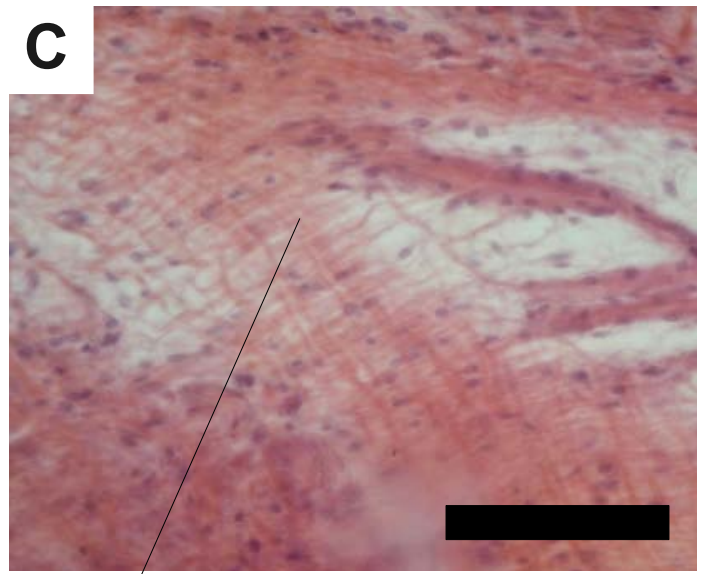

phi

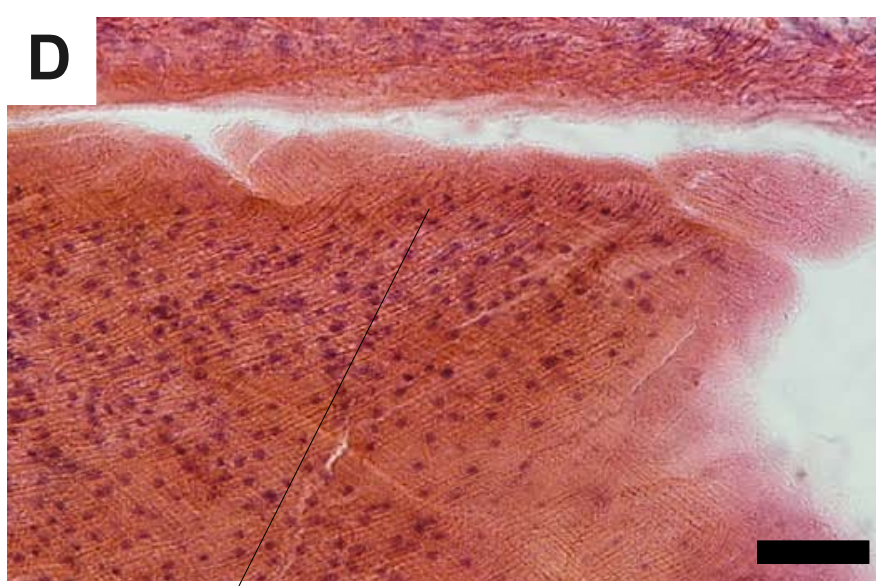

phe

Choeradoplana iheringi von Graff, 1899. Figure 15. Specimen EMF Ch. Iheringi 1. A) Reconstruction of pharynx, scale bar: $500 \mu \mathrm{m}$. B) Photograph of pharynx, scale bar: $200 \mu \mathrm{m}$. C) Photograph of internal pharynx musculature, scale bar: $50 \mu \mathrm{m}$. D) Photograph external pharynx musculature, scale bar: $50 \mu \mathrm{m}$. 

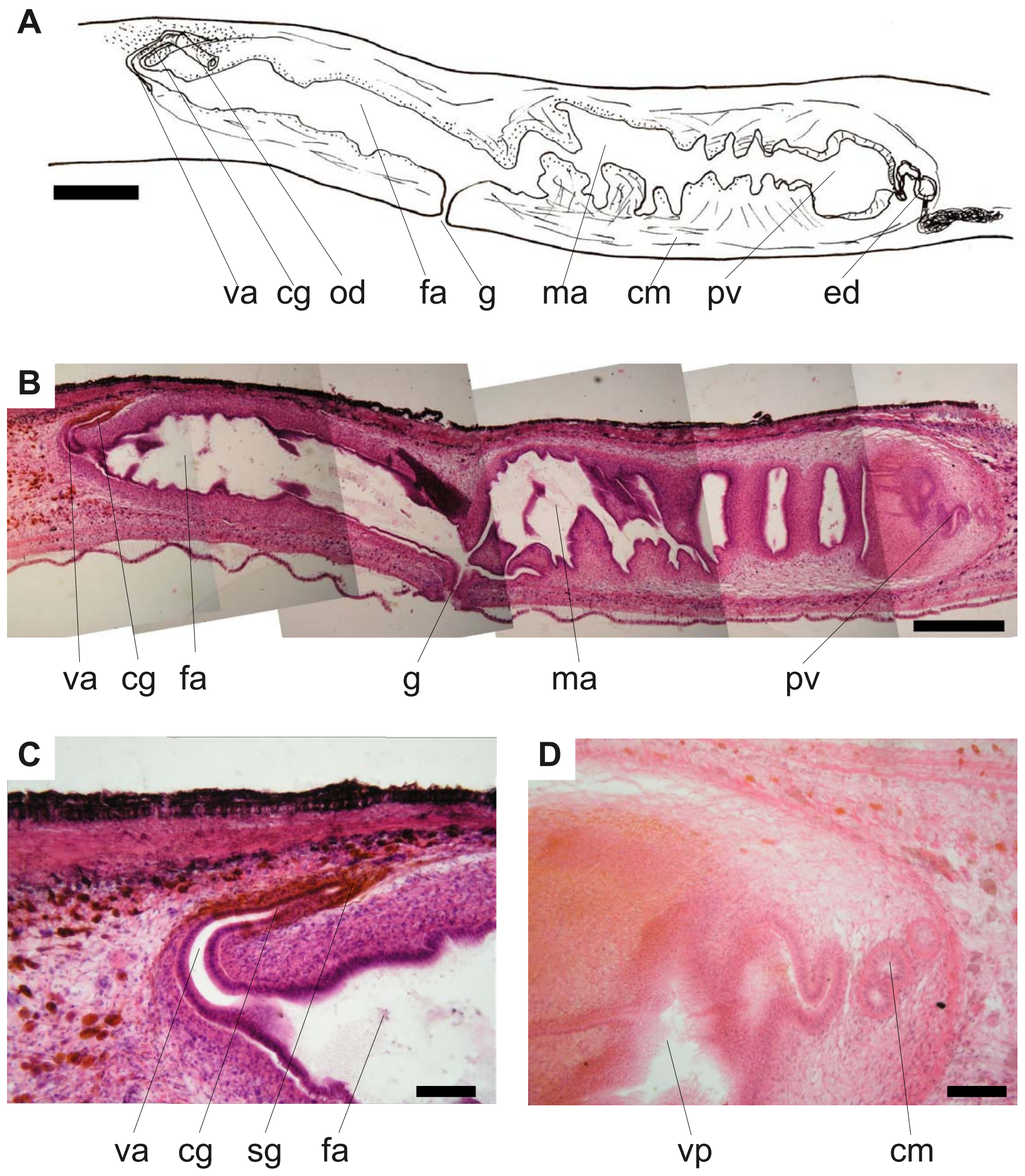

Choeradoplana iheringi von Graff, 1899. Figure 16. Specimen EMF Ch. Iheringi 1.

A) Reconstruction of section of copulatory apparatus, scale bar: $500 \mu \mathrm{m}$. B) Photograph of section copulatory apparatus, scale bar: $500 \mu \mathrm{m}$. C) Photograph of common glandular canal, scale bar: $50 \mu \mathrm{m}$. D) Photograph of prostatic vesicle, scale bar: $50 \mu \mathrm{m}$. 


\section{Dolichoplana carvalhoi Correa 1947}

\section{EXAMINED MATERIAL}

EMF D. carvalhoi 1: Holotype, original material studied by Diva Diniz Correa. Male atrium in 13 slides, female atrium in 10 slides, ovarian region in 3 slides, anterior region 1 in 6 slides, anterior region 2 in 6 slides, prepharyngeal region in 3 slides, pharynx 1 in 2 slides, pharynx 2 in 7 slides.

\section{MORPHOLOGY}

External morphology. Sub cylindrical body (Figure 17A). Creeping sole $50-55 \%$ of body width. Eyes pigment-cup type, about 25-30 $\mu \mathrm{m}$ diameter. Eyes multicellular.

Sub-epidermic musculature. Tripartite musculature. Cutaneous longitudinal muscles in distinct bundles, not insunk (Figure 17B). Dorsal cutaneous musculature (17D) thicker dorsally than ventral musculature (Figure 17C).

Sub-epidermal secretions. Rhabitogen cells underneath dorsal musculature extending dorsolaterally to outer margins of creeping sole. Glandular ridge absent.

Mesenchymal musculature. Mesenchymal musculature composed of 5 layers. Dorsal double diagonal, transversal supra-intestinal, transversal and longitudinal sub-intestinal, subneural ventral plate and a ventral-most decussate diagonal muscle layer underneath the longitudinal ventral plate. Ventral plate formed by longitudinal fibers packed in bundles and transversal fibers.

Digestive system. Mouth located at posterior fourth of the pouch. Pharynx cylindrical, horizontal, with parallel insertions. Esophagus present, about one third the length of the pharynx. External pharyngeal musculature with sub-epithelial longitudinal, followed by circular muscles. Internal pharyngeal musculature composed sub-epithelial longitudinal fibers, followed by a layer of circular muscle fibers. Internal pharynx musculature does not intermixed.

Central nervous system. Organized in two nerve chords.

Male reproductive organs. Testes globular in shape, 130-150 $\mu \mathrm{m}$ in diameter, located ventrally, external to nerve chords. Testes located underneath the longitudinal ventral plate. Testes extending from the root of the pharynx to the gonopore. Testes communicate directly with efferent ducts. The efferent ducts enter separately to the proximal dorsal end of seminal vesicle. Prostatic vesicle intra-bulbar (Figure 18D). Penis papilla absent. Male atrium folded (Figure 18A, 18B). 
Female reproductive organs. Ovaries situated anteriorly above the nerve chords. Ovovitelline ducts arise from posterior walls of ovaries. Ovovitelline ducts pass under transversal sub-intestinal. Vitellaria situated between gut diverticula. Female atrium greatly reduced or absent. Female canals approaching ventrally and forming common oviduct. Common oviduct opens to common glandular canal. Common glandular canal located dorsally, above the gonopore. Shell glands opening to glandular canal only. Common muscular coat wrapping the entire prostatic vesicle, male atrium, female atrium and common glandular canal. Large musculo-glandular organ situated beneath the female glandular canal (Figure 18C). 
A
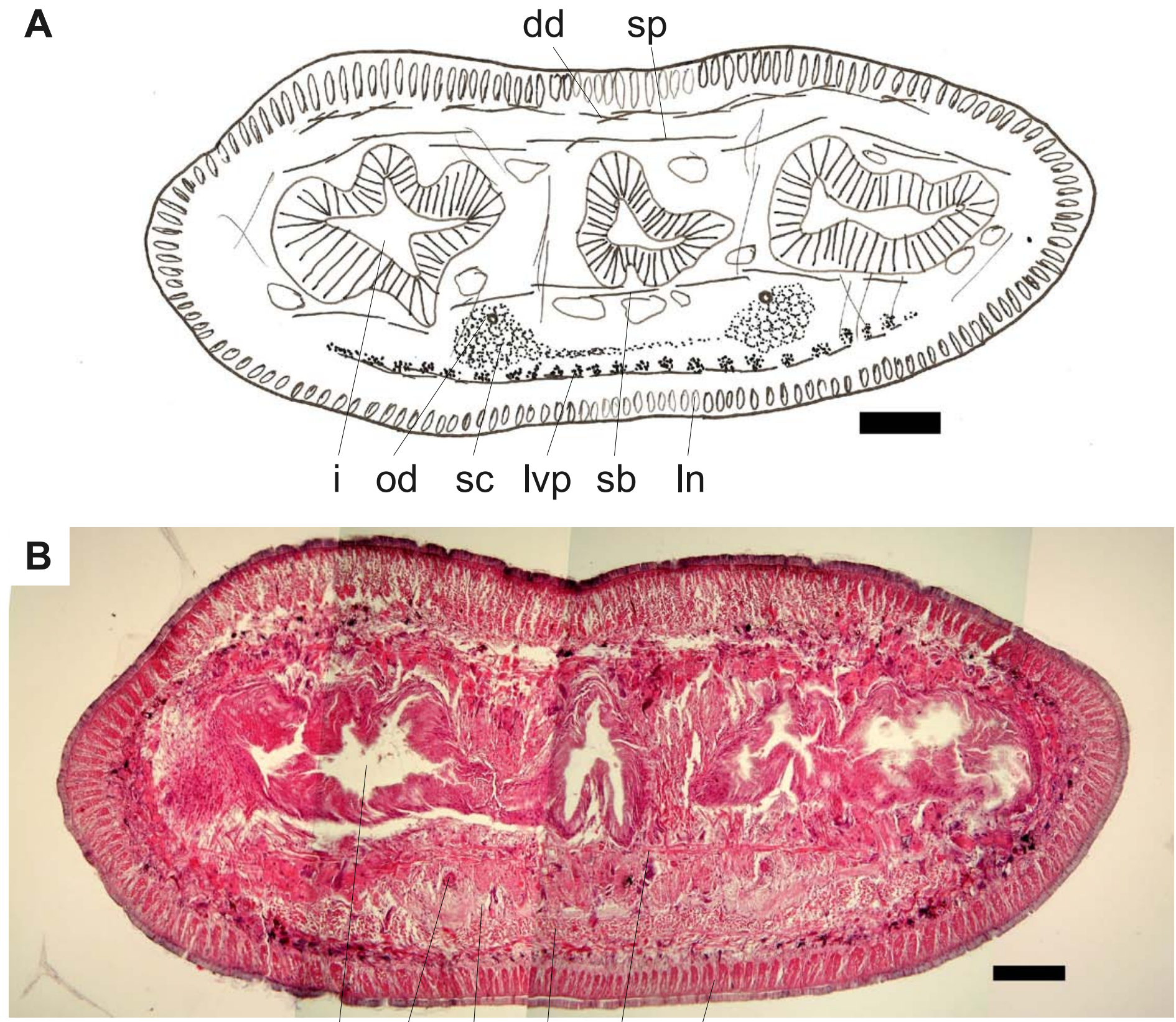

i od sc Ivp sb In
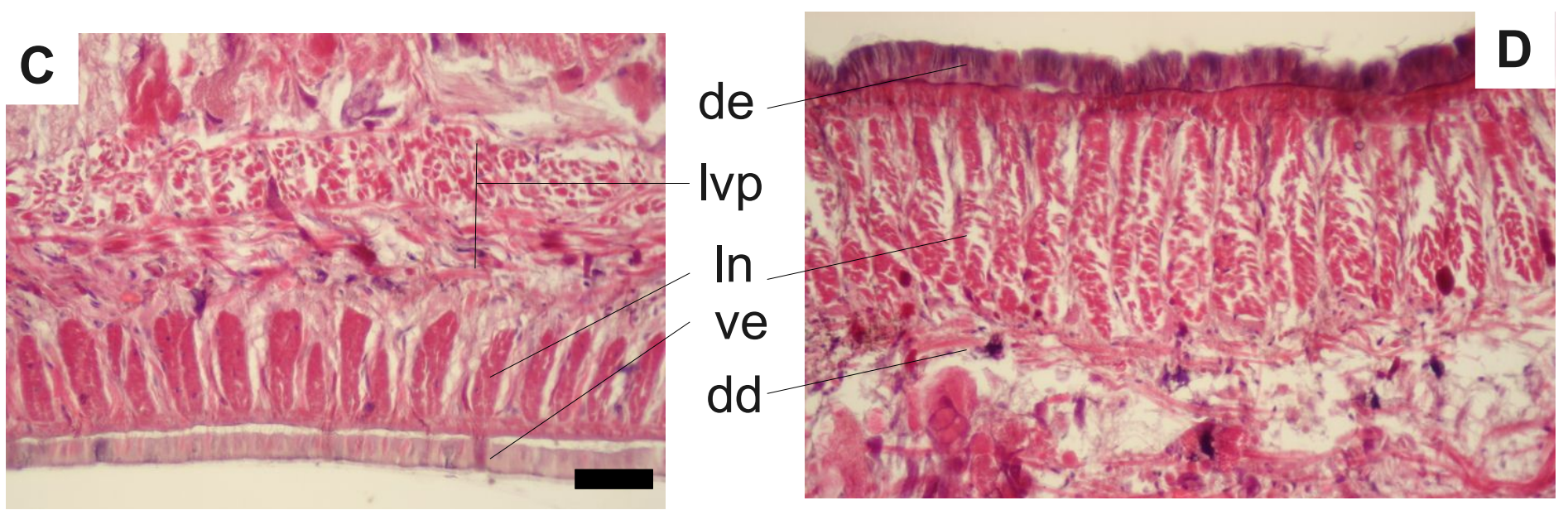

Dolichoplana carvalhoi Correa, 1947. Figure 17. Holotype. A) Reconstruction of section of prepharyngeal region, scale bar: $200 \mu \mathrm{m}$. B) Photograph of section of pre-pharyngeal, scale bar: 200 $\mu \mathrm{m}$. C) Photograph of ventral sub-epidermic musculature, scale bar: $50 \mu \mathrm{m}$. D) Photograph dorsal sub-epidermic musculature, scale bar: $50 \mu \mathrm{m}$. 

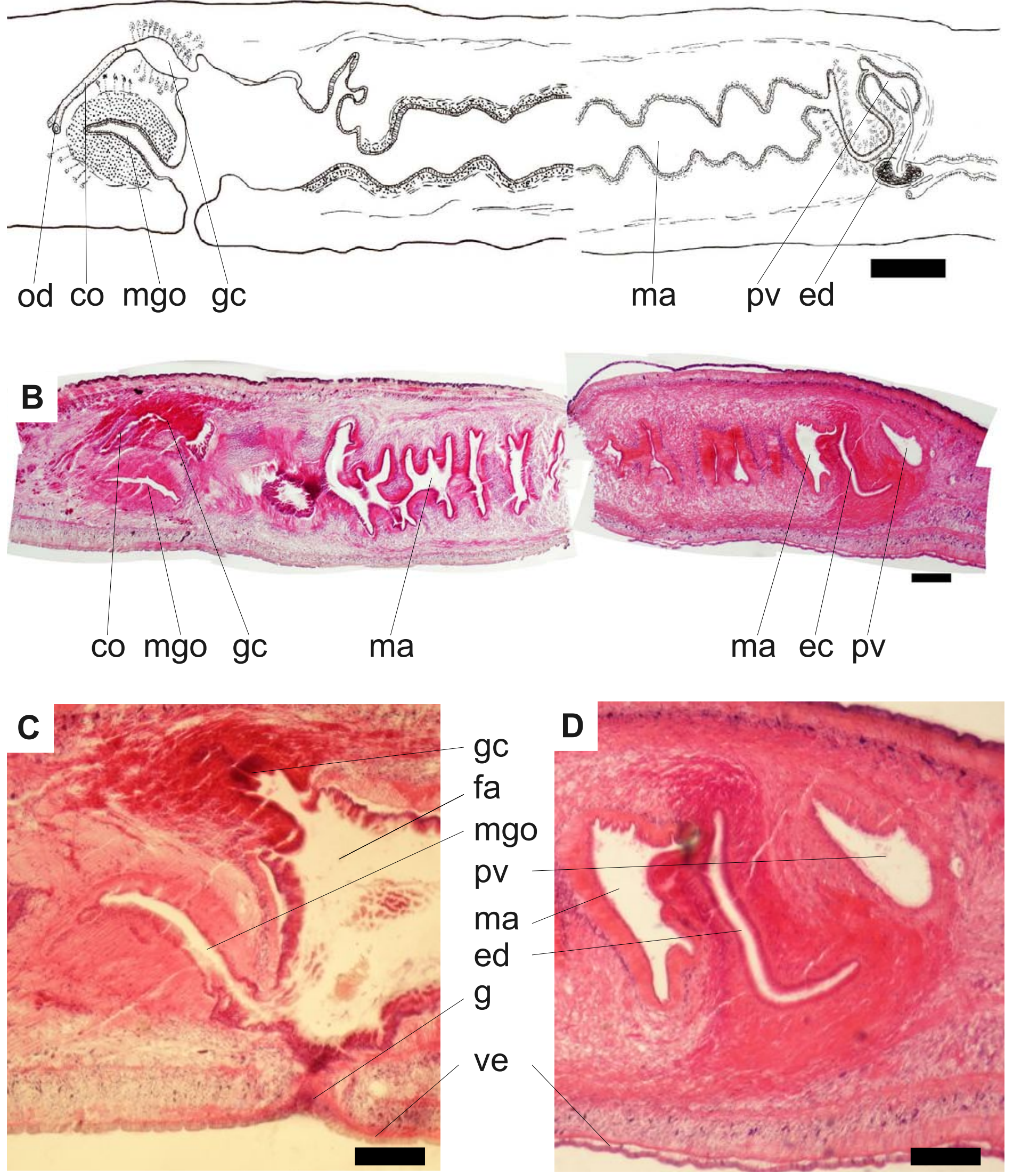

Dolichoplana carvalhoi Correa, 1947. Figure 18. Holotype. A) Reconstruction of section of copulatory apparatus, scale bar: $200 \mu \mathrm{m}$. B) Photograph of sections of the copulatory apparatus, scale bar: $200 \mu \mathrm{m}$. C) Photograph of female region of copulatory apparatus, scale bar: $200 \mu \mathrm{m}$. D) Photograph male region of copulatory apparatus, scale bar: $200 \mu \mathrm{m}$. 


\section{Endeavouria septemlineata (Hyman, 1939)}

\section{SYNONYM}

Geoplana septemlineata Hyman, 1939.

\section{EXAMINED MATERIAL}

FCB 636: Sagittal sections of copulatory apparatus on 10 slides. Transversal sectoins of pre-pharyngeal region on 4 slides. Sagittal sections of pharynx on 6 slides. Parque estadual Tiete, São Paulo Brazil.

\section{MORPHOLOGY}

External morphology. Sub cylindrical body (Figure 19A). Creeping sole $50-55 \%$ of body width. Eyes pigment-cup type, about 25-30 $\mu \mathrm{m}$ diameter. Eyes multicellular.

Sub-epidermic musculature. Tripartite musculature. Cutaneous longitudinal muscles in distinct bundles, not insunk (Figure 19B). Dorsal cutaneous musculature (Figure 19D) thicker than ventral musculature.

Sub-epidermal secretions. Rhabitogen cells underneath dorsal musculature extending dorso-laterally to outer margins of creeping sole. Glandular ridge absent.

Mesenchymal musculature. Mesenchymal musculature composed of 4 layers. Dorsal double diagonal, transversal supra-intestinal, transversal and longitudinal sub-intestinal and sub-neural ventral plate. Sub-neural ventral plate formed by longitudinal and transversal muscle fibers, not packed in bundles.

Digestive system. Mouth located at posterior fourth of the pouch (Figure 20A, 20B). Pharynx cylindrical, horizontal, with parallel insertions. Esophagus present about one third the length of the pharynx. External pharyngeal musculature (Figure 20C) with sub-epithelial longitudinal, followed by circular muscles. Internal pharyngeal musculature (Figure 20D) composed sub-epithelial circular and longitudinal fibers. Internal pharynx musculature intermixed.

Central nervous system. Organized into two nerve chords.

Male reproductive organs. Testes globular in shape, 130-150 $\mu \mathrm{m}$ in diameter, located ventrally, external to nerve chords (Figure 19C). Testes located underneath the sub-intestinal mesenchymal layer. Testes extending from the region of the ovaries to copulatory apparatus. Testes communicate directly with efferent ducts. The Efferent ducts unite before entering the proximal dorsal end of the seminal vesicle. Prostatic vesicle intra-penial. Penis papilla 
eversible type (Figure 21D). Male atrium folded (Figure 21A). Wide ventral inter-atrial fold above the gonopore (Figure 21B). Male atrium highly muscularized. Female glandular canal present (Figure 21C).

Female reproductive organs. Ovaries situated anteriorly. Ovaries embedded in ventral nerve cords. Ovovitelline ducts arise from dorsal-lateral walls of ovaries. Ovovitelline ducts run underneath transversal sub-intestinal. Vitellaria situated between gut diverticula. Female atrium about half the size of male atrium. Female canals approaching ventrally and forming common glandular duct. Shell glands opening to glandular canal. Female atrium with tall secretive epithelia. Common muscular coat wrapping the entire prostatic vesicle, male atrium, female atrium and common glandular canal. 
A

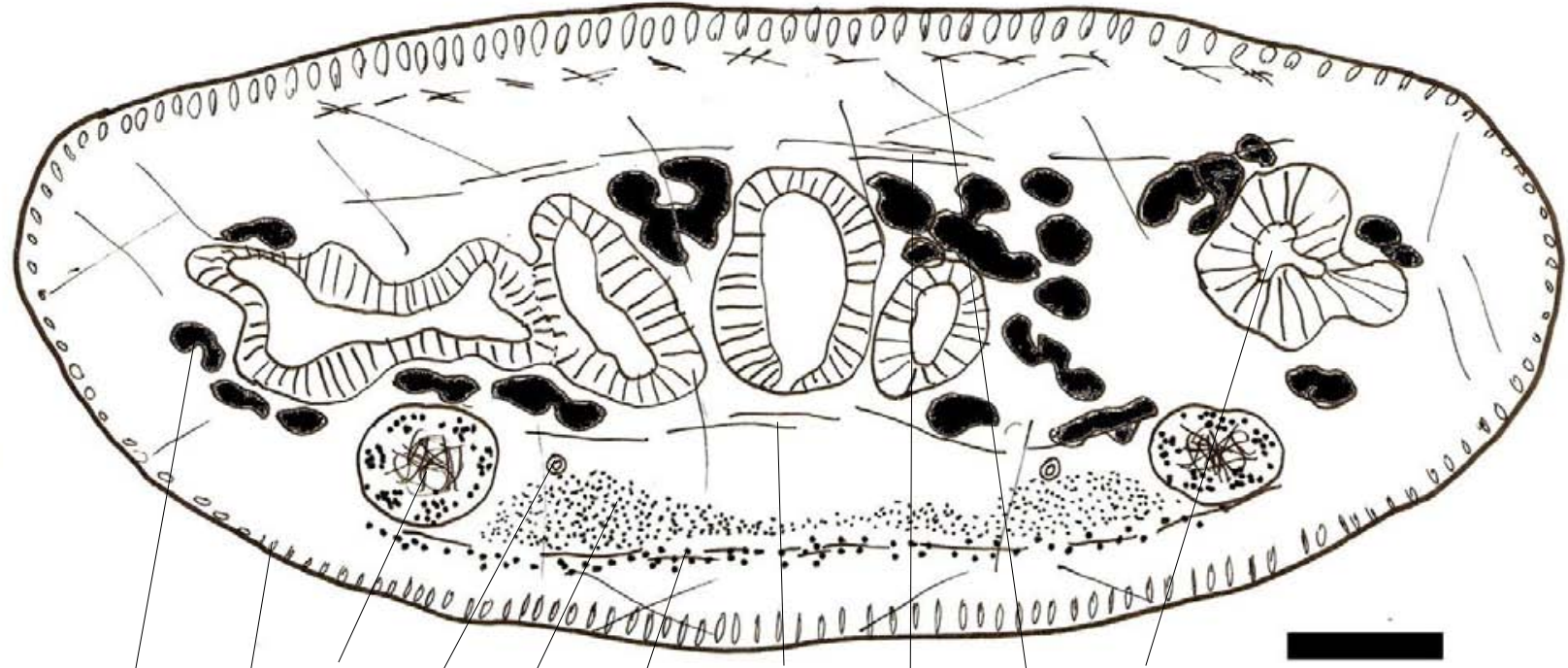

vi In $t$ od sc Ivp sb sp dd i
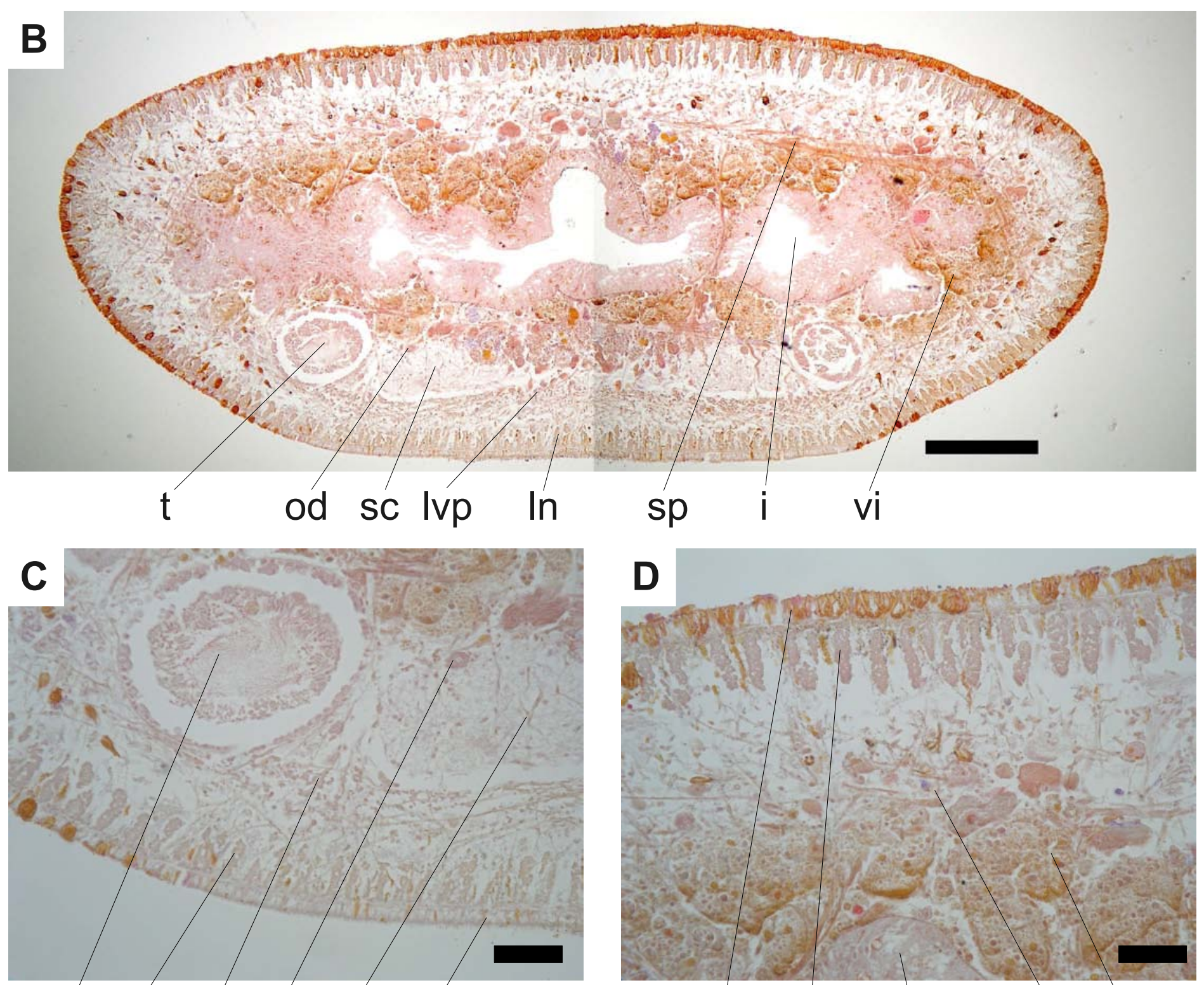

$t$ In Ivp od sc ve
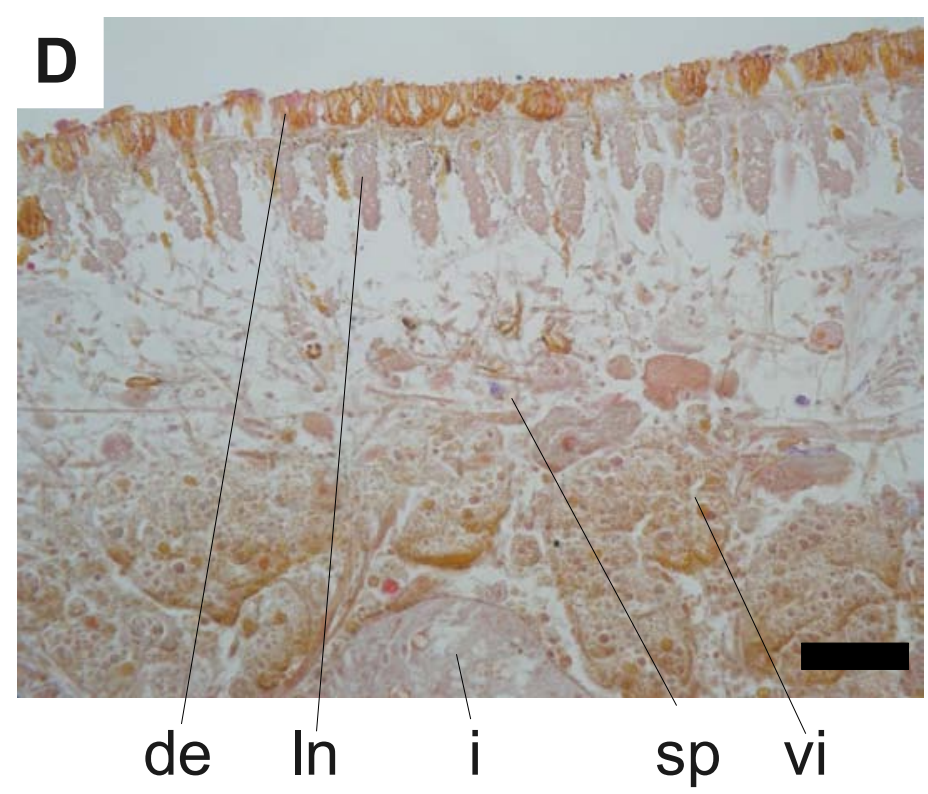

Endeavouria septemlineata (Hyman, 1939). Figure 19. Specimen FCB 636. A) Reconstruction of transversal section, scale bar: $200 \mu \mathrm{m}$. B) Photograph of transversal section, scale bar: $200 \mu \mathrm{m}$. C) Photograph of the ventral sub-epidermic musculature, scale bar: $50 \mu \mathrm{m}$. D) Photograph of the dorsal sub-epidermic musculature, scale bar: $50 \mu \mathrm{m}$. 

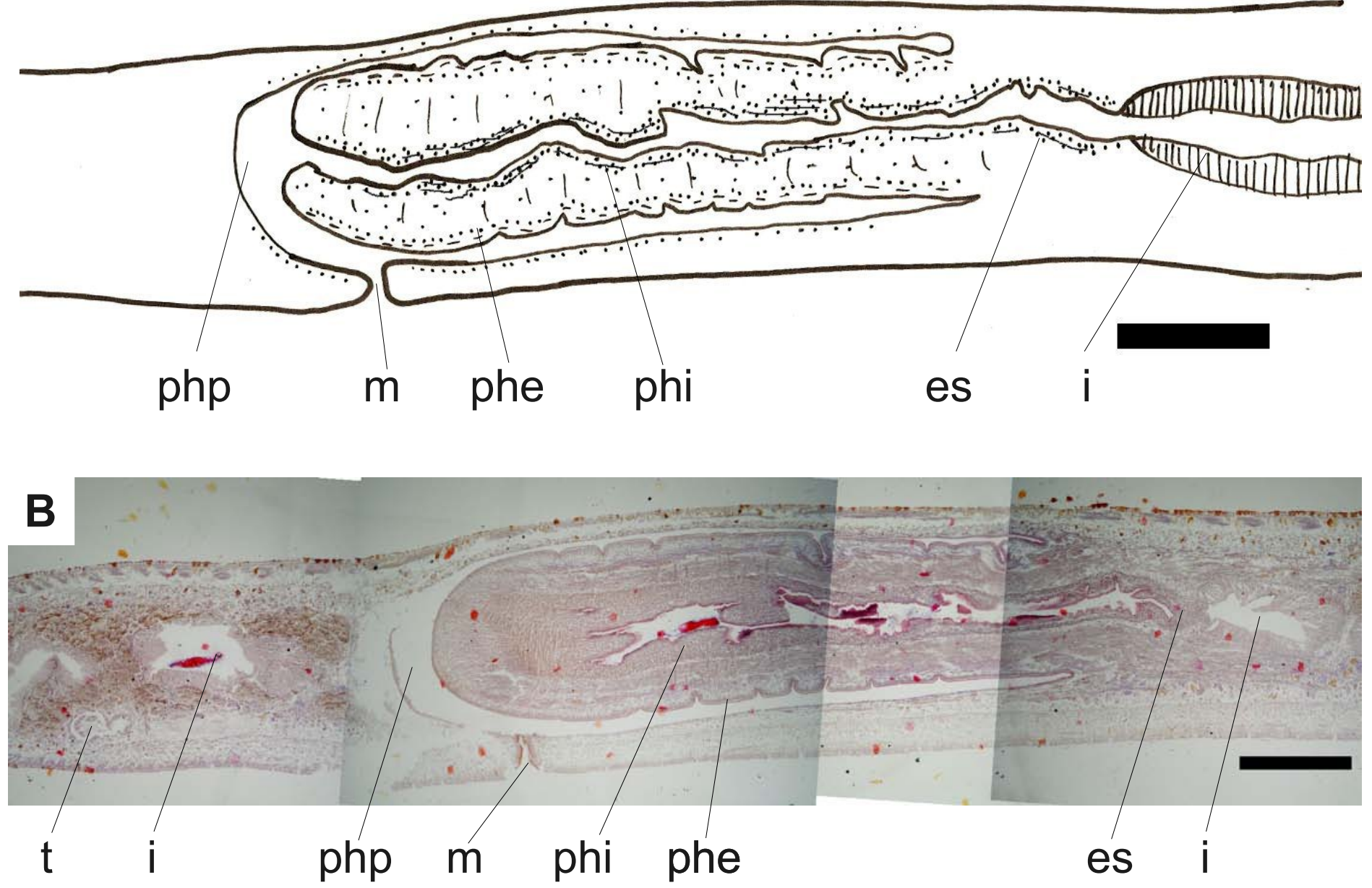

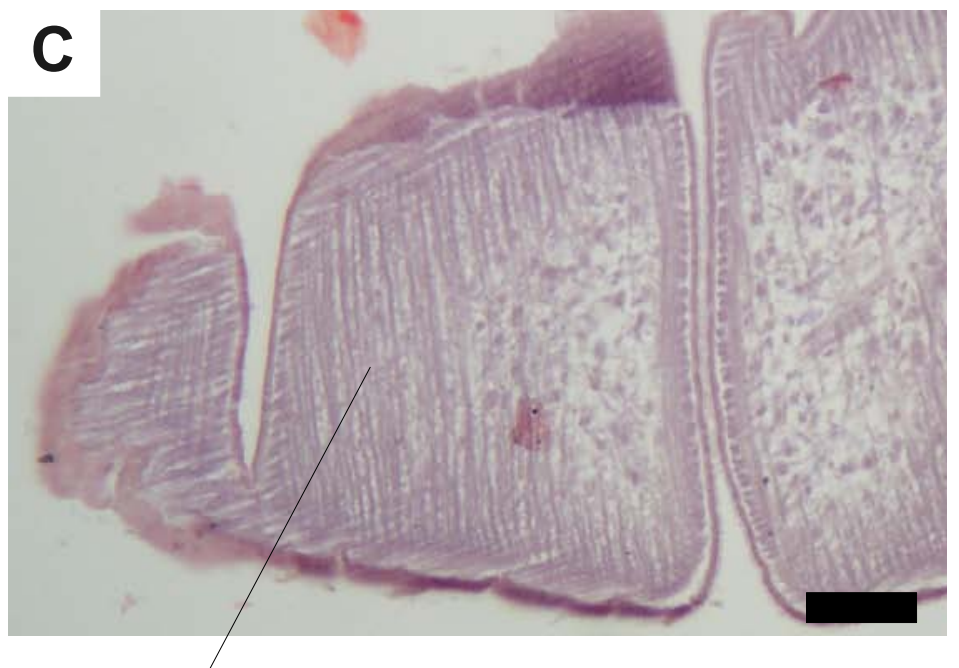

phe

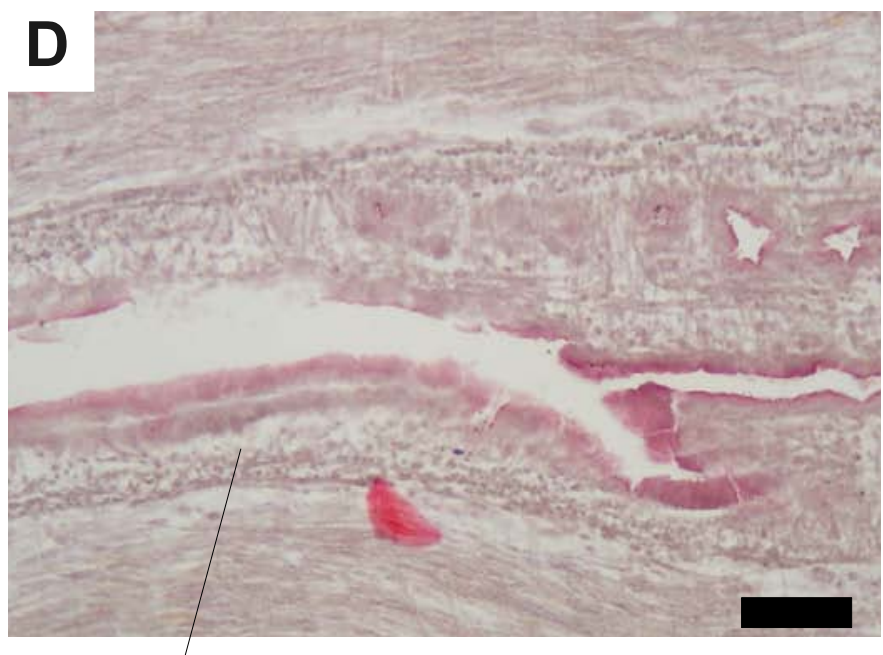

phi

Endeavouria septemlineata (Hyman, 1939). Figure 20. Specimen FCB 636. A) Reconstruction of pharynx, scale bar: $500 \mu \mathrm{m}$. B) Photograph of pharynx, scale bar: $400 \mu \mathrm{m}$. C) Photograph of external pharynx musculature, scale bar: $50 \mu \mathrm{m}$. D) Photograph of internal pharynx musculature, scale bar: $50 \mu \mathrm{m}$. 
A
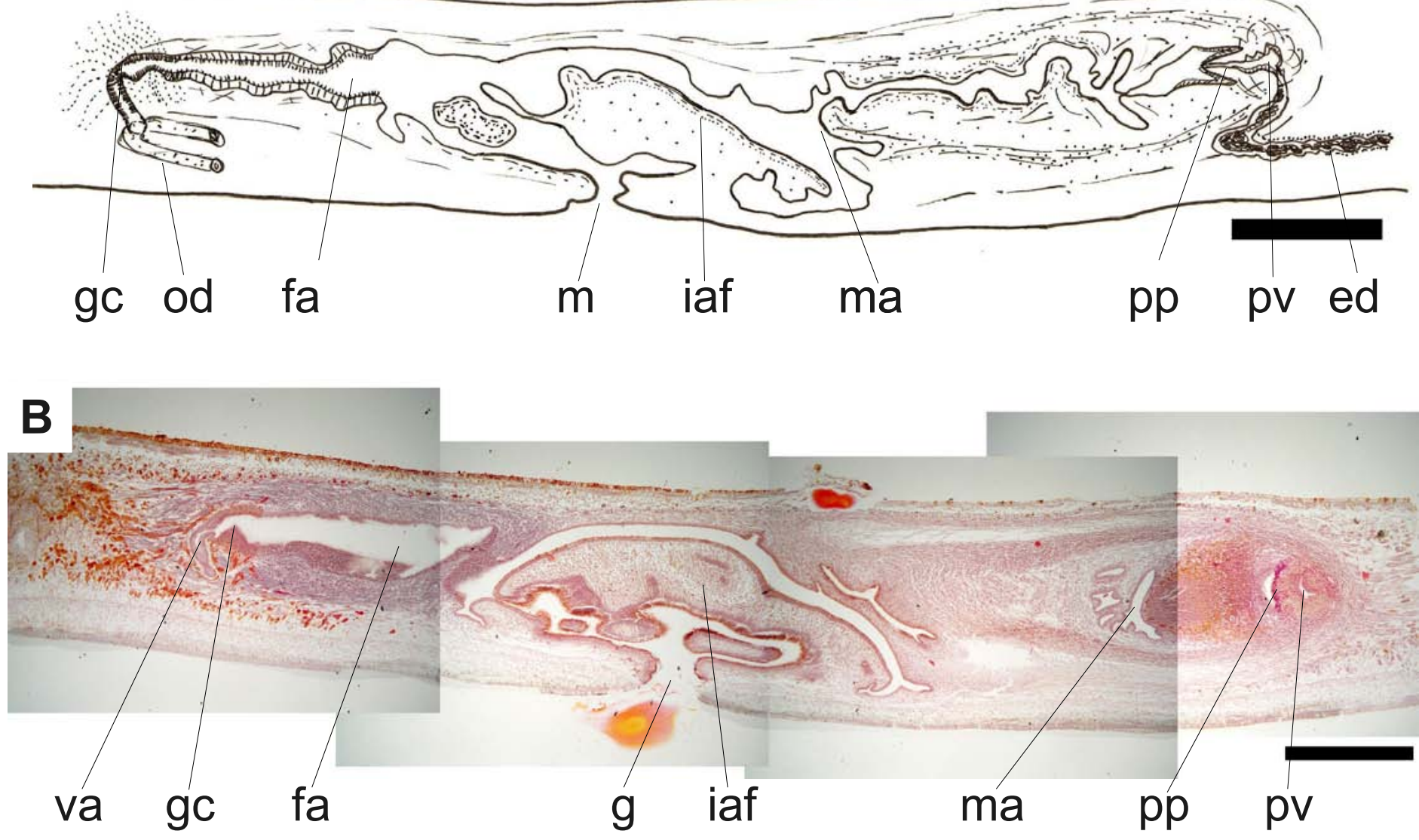

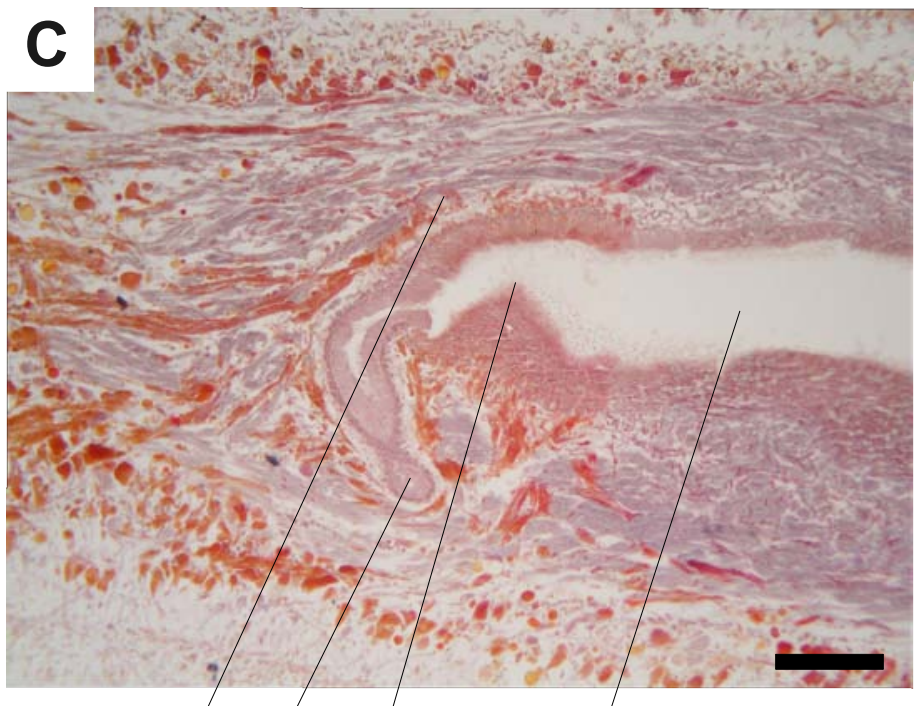

sg od gc

$\mathrm{fa}$

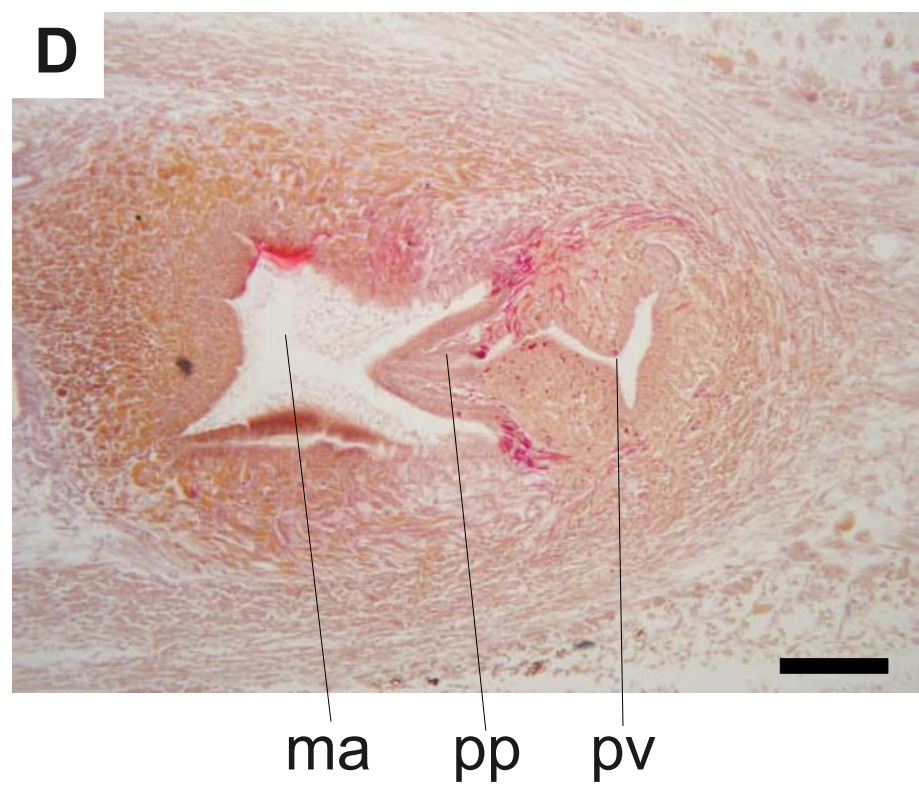

Endeavouria septemlineata (Hyman, 1939). Figure 21. Specimen FCB 636. A) Reconstruction of copulatory apparatus, scale bar: $500 \mu \mathrm{m}$. B) Photograph of copulatory apparatus bar: $500 \mu \mathrm{m}$. C) Photograph of glandular canal, scale bar: $100 \mu \mathrm{m}$. D) Photograph of penis papilla, scale bar: $100 \mu \mathrm{m}$. 


\section{Enterosyringa pseudorhynchodemus (Riester, 1938)}

\section{SYNONYM}

Geoplana pseudorhynchodemus n. sp. Riester, 1938.

\section{EXAMINED MATERIAL}

EMF E. ps. 1: Horizontal sections of copulatory apparatus on 1 slide. EMF E. ps. 2: Sagittal sections of pharynx and copulatory apparatus on 2 slides. EMF E. ps. 3: Whole mount.

EMF E. ps. Janeiro 66: Sagittal sections of prepharynx and pharynx on 6 slides. EMF E. ps. 4: Transversal sections of prepharyngeal region on 1 slide. EMF E. ps. 5: Transversal sections of anterior part on 1 slide.

\section{MORPHOLOGY}

External morphology. Cylindric body shape in in cross section (Figure 23A). Anterior part gradually tapering into thin anterior end. Creeping sole densely ciliated occupying about $50 \%$ of body width. Eyes present in anterior tip. Distributed in a single row in the anterior part. Eyes placed in lower half of body (Figure 22B), extending to posterior tip. Sensory pits consist of simple invagination surrounding anterior tip (Figure 22A).

Sub-epidermic musculature. Cutaneous musculature tripartite, although the double diagonal and the circular layer very reduced. Longitudinal musculature packed a small separate bundles. Dorsal cutaneous musculature $(30 \mu \mathrm{m})$ stronger than ventral $(18 \mu \mathrm{m})$.

Sub-epidermic secretions. Dense insunk secretions accumulations forming a secretory keel (Figure 23B). In the cephalic region no glandular specialization were observed.

Mesenchymal musculature. Composed of dorsal double diagonal, transversal supraintestinal, transversal sub-intestinal. Longitudinal ventral plate. Longitudinal mesenchymal musculature absent.

Digestive system. Small cylindrical pharynx (Figure 24A). Mouth located at posterior end of pharyngeal pouch. Esophagus present, extending half the length of the pharynx. Pharyngeal pocket composed of circular musculature. External pharynx musculature (Figure 24C) composed of sub-epithelial longitudinal muscle fibers followed by thin circular muscle layer. Internal pharynx epithelium ciliated. Internal pharynx musculature composed of subepithelial circular followed by longitudinal.

Central nervous system. Two nerve chords.

Male reproductive organs. Testes Dorsal. Extending from anterior region until the root 
of the pharynx. Testes globular tall up to $120 \times 350 \mu \mathrm{m}$. Efferent ducts internal to subintestinal mesenchymal layer. Efferent duct extending up to penis bulb, turning dorsally and fusing into common efferent duct that opens directly to the prostatic vesicle. Prostatic vesicle tubular shaped, slightly orientated downwards (Figure 25B). Prostatic vesicle with columnar ciliated epithelium and xanthophyll secretions. Efferent ducts musculature composed of circular musculature, lined with. flat epithelium. Male atrium with cuboidal ciliated epithelium. Penis papilla with columnar ciliated epithelium. Penis stroma with longitudinal fibers, forming a strong and dense penial bulb (Figure 25C).

Female reproductive organs. Ovaries placed posteriorly, just anterior to pharynx (Figure 24B) and placed above transversal sub-intestinal mesenchymal muscle layer. Oviduct arising from dorso-external part of ovaries. Oviducts placed internal to sub-intestinal mesenchymal layer. Vagina elongated and curved downwards (Figure 25A). Female atrium small, penis papilla almost invading female atrium. Musculature composed of circular musculature. Oviducts composed of reticular musculature. Shell glands delivered in common oviduct and vagina. 


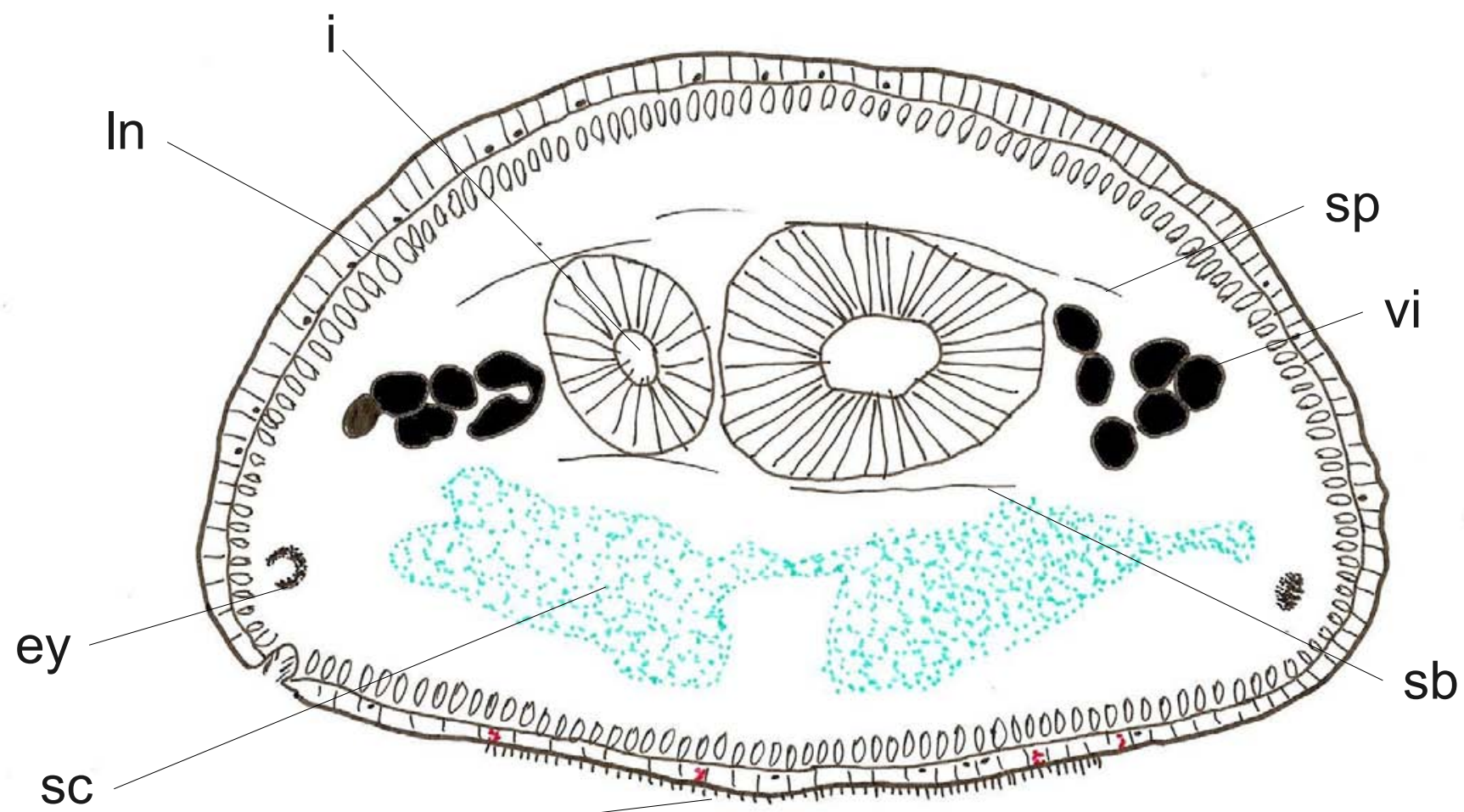

CS

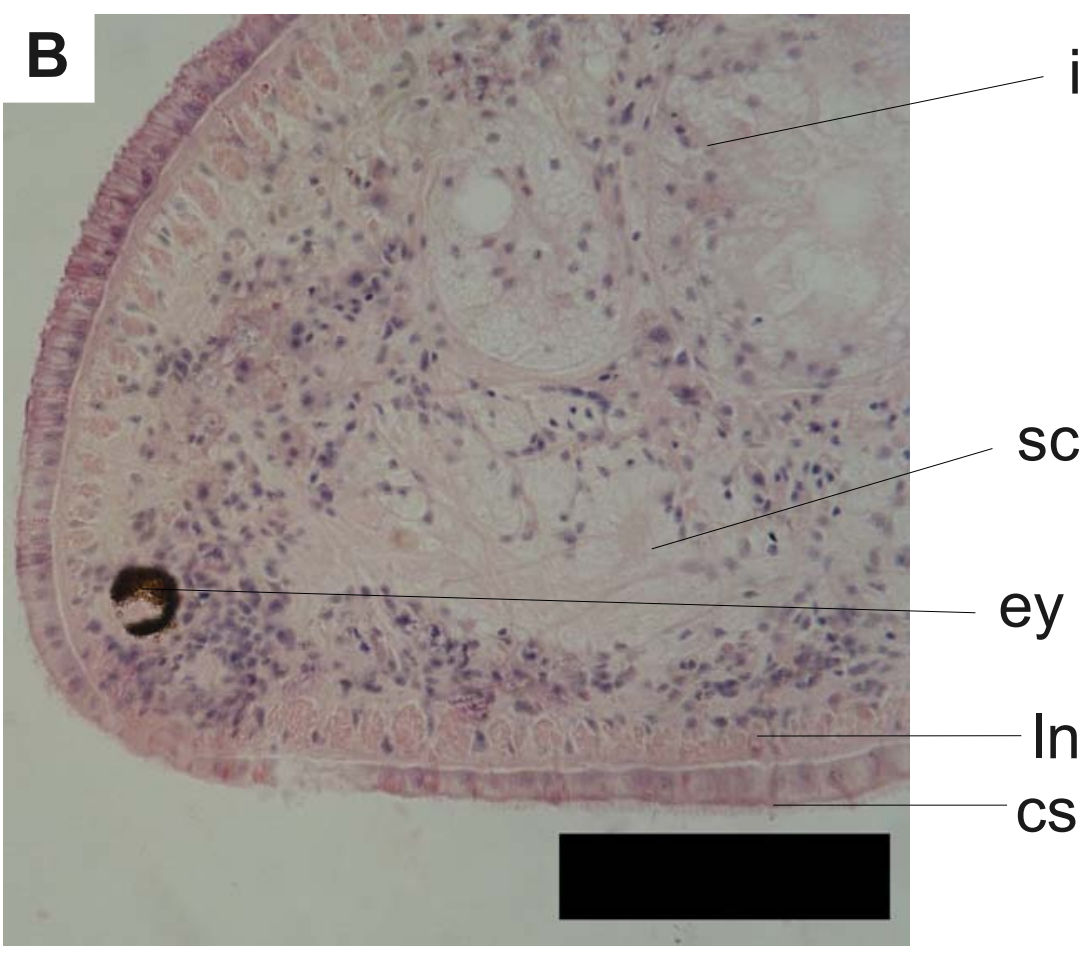

\section{Enterosyringa}

pseudorhynchodemus

(Riester, 1938). Figure 22.

ey Specimen EMF E.ps.5.

A) Reconstruction of section of the cephalic region, scale bar: $250 \mu \mathrm{m}$. B) Photograph of eye and sensory pit, scale bar: 250 $\mu \mathrm{m}$. 
A

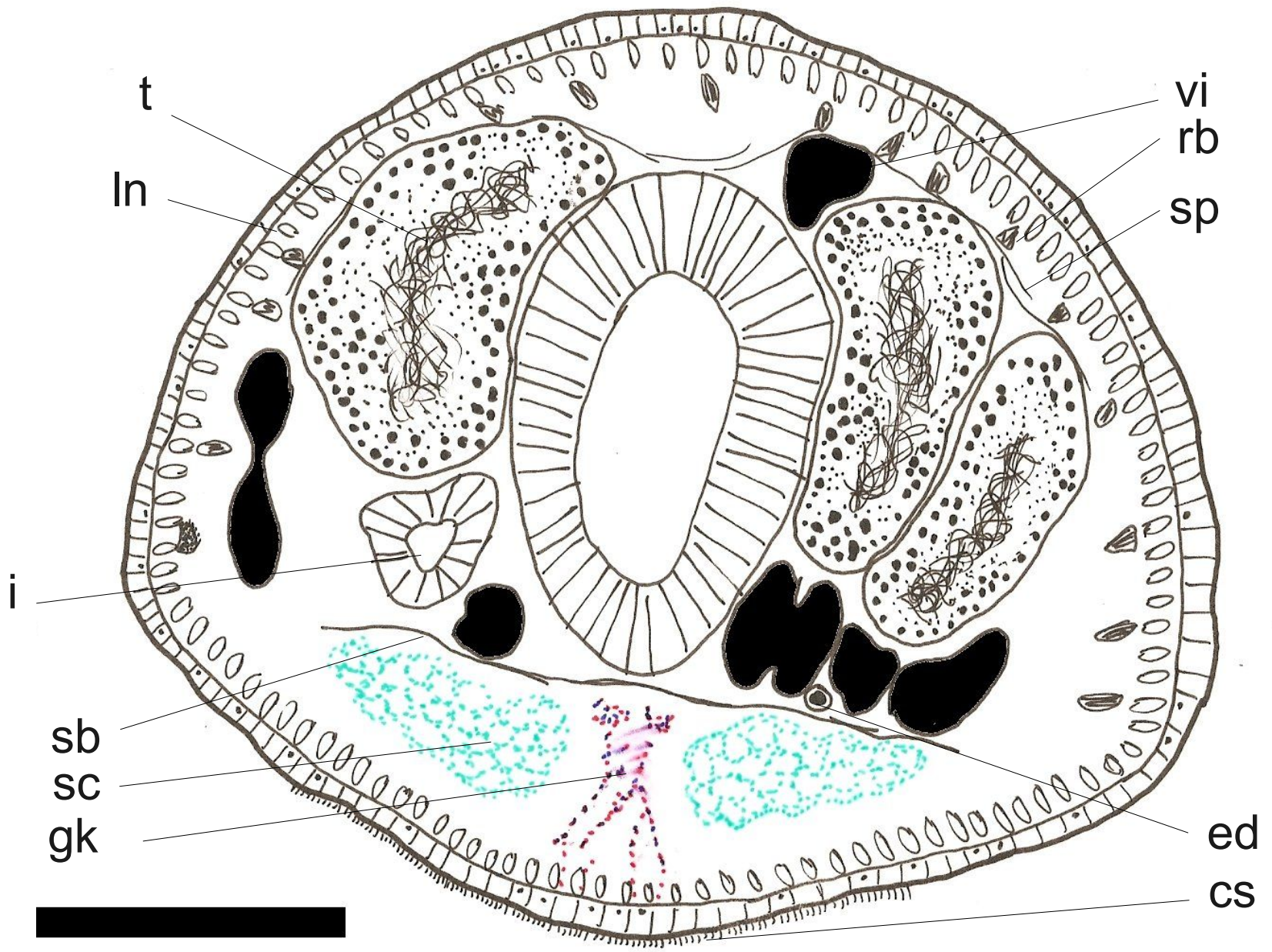

B

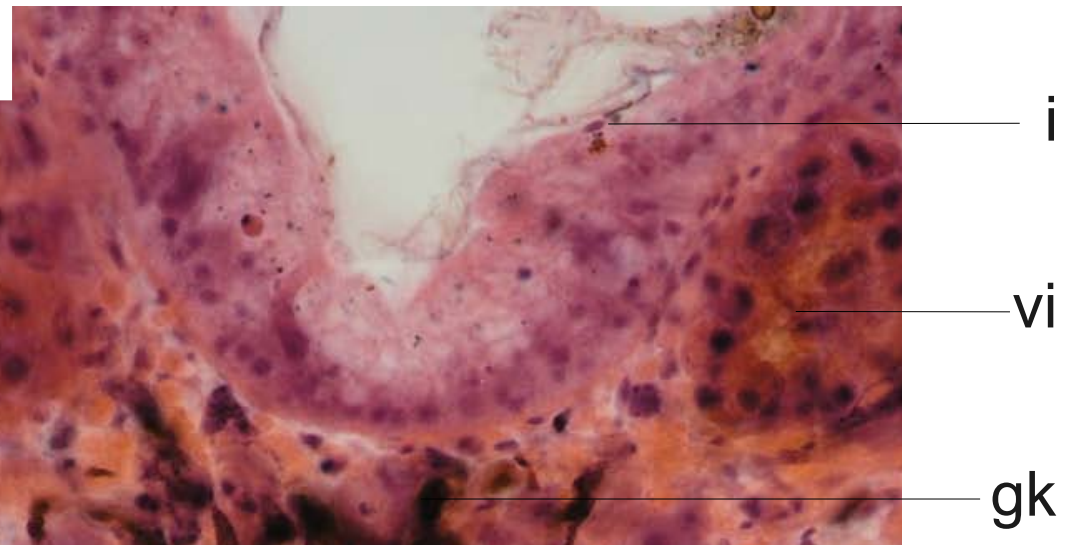

SC

In

\section{Enterosyringa}

pseudorhynchodemus

(Riester, 1938). Figure 23.

Specimen EMF.E.ps.4.

A) Reconstruction of section of the pre-pharyngeal region, scale bar: $250 \mu \mathrm{m}$.

B) Photograph of glandular keel, scale bar: $250 \mu \mathrm{m}$. 
A
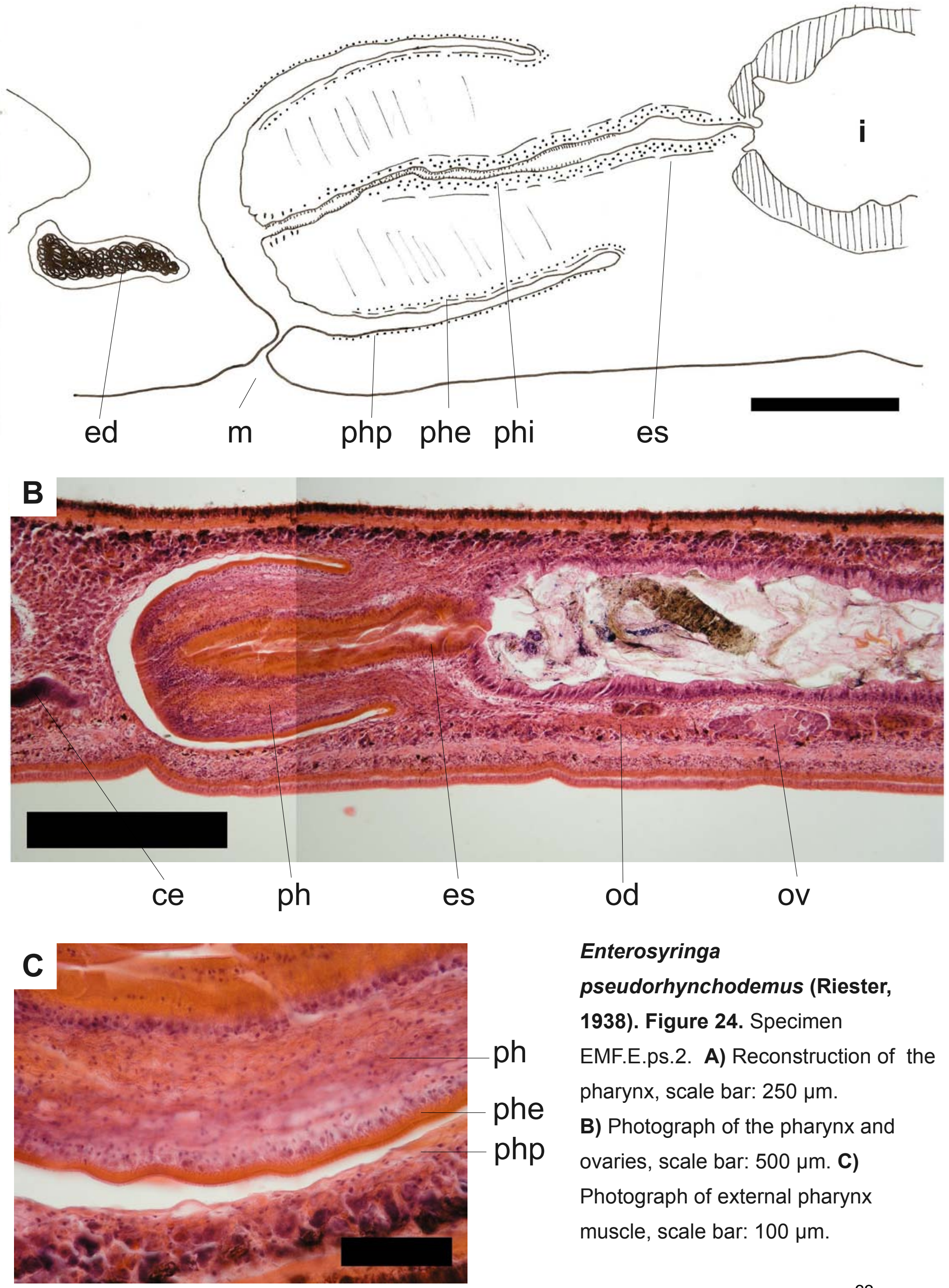

Enterosyringa pseudorhynchodemus (Riester, 1938). Figure 24. Specimen

EMF.E.ps.2. A) Reconstruction of the pharynx, scale bar: $250 \mu \mathrm{m}$.

B) Photograph of the pharynx and ovaries, scale bar: $500 \mu \mathrm{m}$. C) Photograph of external pharynx muscle, scale bar: $100 \mu \mathrm{m}$. 
A
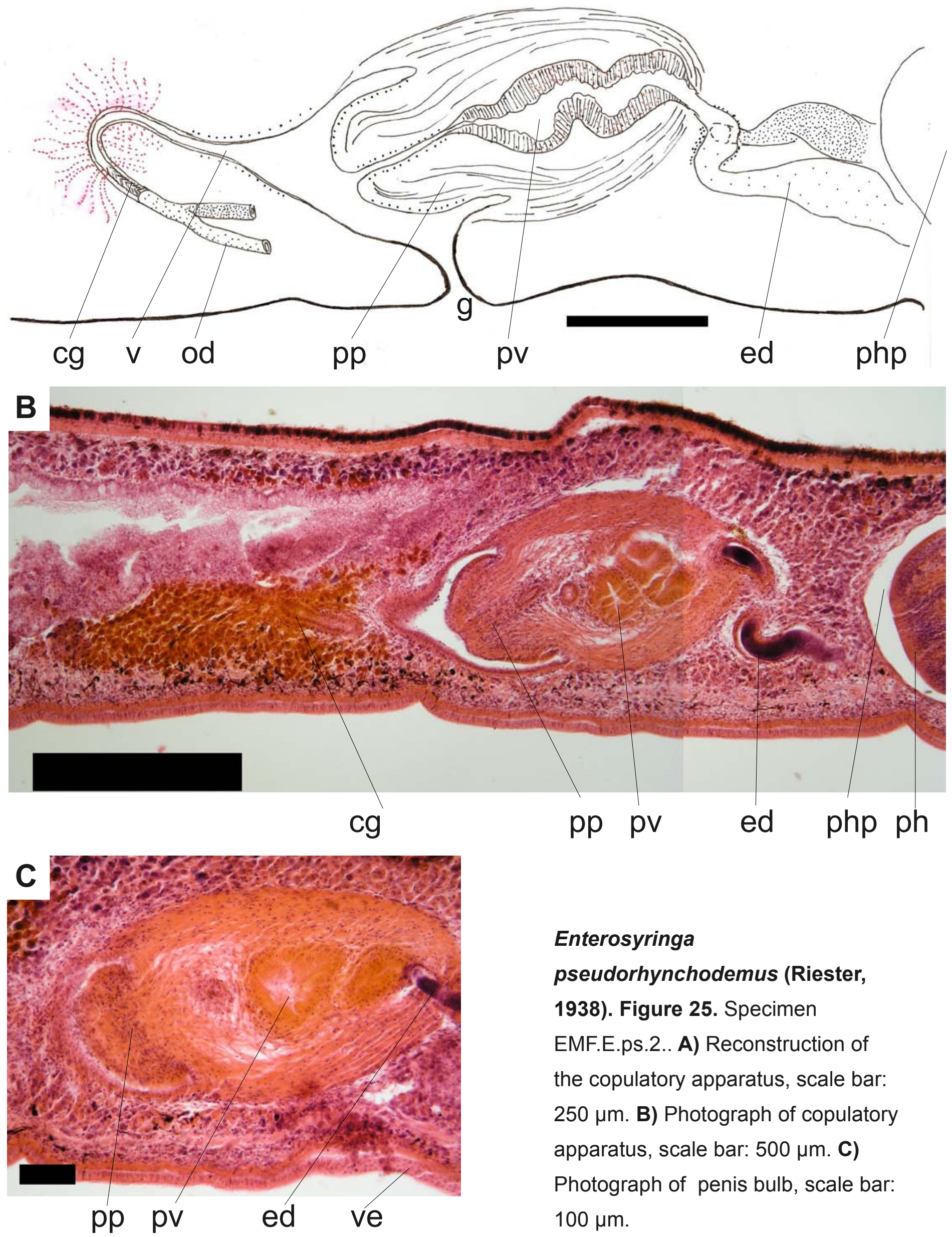

\section{Enterosyringa}

pseudorhynchodemus (Riester,

1938). Figure 25. Specimen

EMF.E.ps.2.. A) Reconstruction of the copulatory apparatus, scale bar: $250 \mu \mathrm{m}$. B) Photograph of copulatory apparatus, scale bar: $500 \mu \mathrm{m}$. C) Photograph of penis bulb, scale bar: $100 \mu \mathrm{m}$. 


\section{Geobia subterranea (Schultze \& Müller, 1857)}

\section{SYNONYM}

Geoplana subterranea: n. sp. Schultze \& Müller, 1857.

\section{EXAMINED MATERIAL}

EMF G.s. 10/II/1954: Teresopolis RJ. Transversal sections of anterior part on 1 slide. Sagittal sections of pharynx on 2 slides. EMF G.s. 12/VII/1954. São Paulo SP: Transversal sections of pre-pharynx on 1 slide. Sagittal sections of copulatory apparatus on 2 slides. Horizontal sections of anterior part on 2 slides. EMF G. subterranea: whole mount specimen.

\section{MORPHOLOGY}

External morphology. Thin long unpigmented worm. Creeping sole absent, totally reduced or very sparsely spread through body surface. Eyes absent. Sensory pits present as single invaginations about $50 \mu \mathrm{m}$ deep. Sensory pits disposed in a single row in the anterior part of the body.

Sub-epidermal musculature. Tripartite muscular composition. Through out the whole animal, the circular ans double diagonal musculatures out-stands for their thickness (Figures 26C, 26D). Same muscular arrangement in the pre-pharyngeal region and in the the cephalic region. In transversal sections of the cephalic regions, the cutaneous musculature is thicker in the dorsally than ventrally. There is an evident decrease in the strength of cutaneous musculature towards the posterior end of the animal.

Sub-epidermic secretions. Epidermis slightly ciliated dorsally and ventrally. In the anterior region epithelium equally thick dorsally and ventral reaching up to $25 \mu \mathrm{m}$ thick. Cyanophyll and erythrophyll glands open thought the whole surface. Ventro-laterally erythrophyll. Glandular ridge absent. In the anterior region of the body, cyanophyll glands opening mainly on the dorsal side and on the lateral; and in predominantly erythrophyll on the ventral side. Rhabditogen cells associated to the whole epidermis.

Mesenchymal musculature. Mesenchymal musculature gathered in three layers; transversal supra-intestinal, transversal sub-intestinal, and double diagonal. Mesenchymal sub-intestinal and supra-intestinal strongest in anterior region, forming bundles (Figure 26A, 26B), specially the sub-intestinal which may form bundles of 37-40 $\mu \mathrm{m}$ thick. and spreading diagonally. Longitudinal mesenchymal musculature absent. 
Digestive system. Mouth in the middle of pharyngeal pocket (Figure 27A). Collard shape pharynx (Figure 27B). Esophagus present. Pharyngeal pocket composed mainly of circular fiber ,although longitudinal fibers are not absent. External pharynx musculature (Figure 27C) composed of longitudinal and circular musculature. Abundantly cyanophyll and xanthophyll secretions. Internal pharynx musculature composed of sub-epithelial circular, with a few external longitudinal fibers. Internal musculature does not intermix. Epidermis abundantly ciliated, and nucleated. Abundantly cyanophyll and xanthophyll secretions

Central Nervous system. Organized in flat nervous plexus.

Male reproductive organs. Testes located dorsally underneath the transversal supraintestinal mesenchymatical layer, extending from anterior region to pre-pharyngeal region. Each testicle communicated with the efferent duct through a thin dorso-ventral channel. Prostatic vesicle globular cavity (Figure 28A). Prostatic vesicle with thin reticular musculature. Tall columnar nucleated epithelium with long cilia. Ejaculatory duct present. Ejaculatory duct same type of epithelium as prostatic vesicle. Efferent ducts accompanied by thick circular and longitudinal muscular fibers in their last portion before entering the prostatic vesicle. Male atrium musculature composed of circular longitudinal fibers. Male atrium with tall columnar epithelium. Penis papilla derived from atrial fold (Figure 28C). Small penis bulb formed by weak muscle fibers.

Female reproductive organs. Ovovitelline musculature reticular, ciliated and nucleated. Ovovitelline placed underneath the transversal sub-intestinal layer. Ovovitelline rising fusing and forming common glandular duct. Shell glands opening into distal portion of ovovitelline ducts and into the common glandular duct (Figure 28D). Vagina placed in posterior dorsal corner of female atrium. Female atrium with tall nucleated and vacuolated epithelium (Figure 28B). Common muscular coat wrapping mainly female and male atriums. 
di

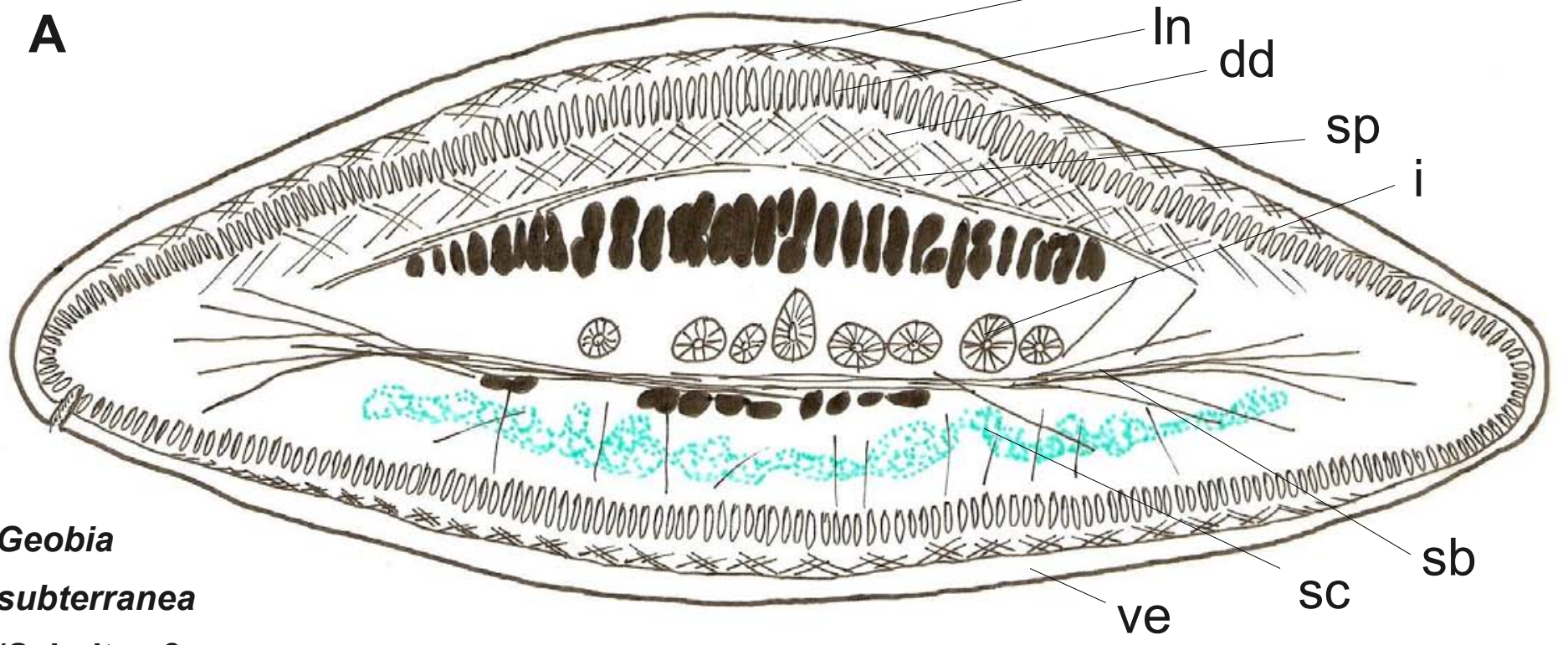

(Schultze \&

Müller, 1857).

Figure 26.

Specimen EMF

12/VII/1954.

A)

Reconstruction of section of anterior part, scale bar: 500 $\mu \mathrm{m}$. B)

Photograph of section of anterior part , scale bar: 500 $\mu \mathrm{m}$. C)

Photograph of dorsal subepidermal musculature, scale bar: 200 $\mu \mathrm{m}$. D)

Photograph of ventral subepidermal al musculature, scale bar: 200 $\mu \mathrm{m}$.

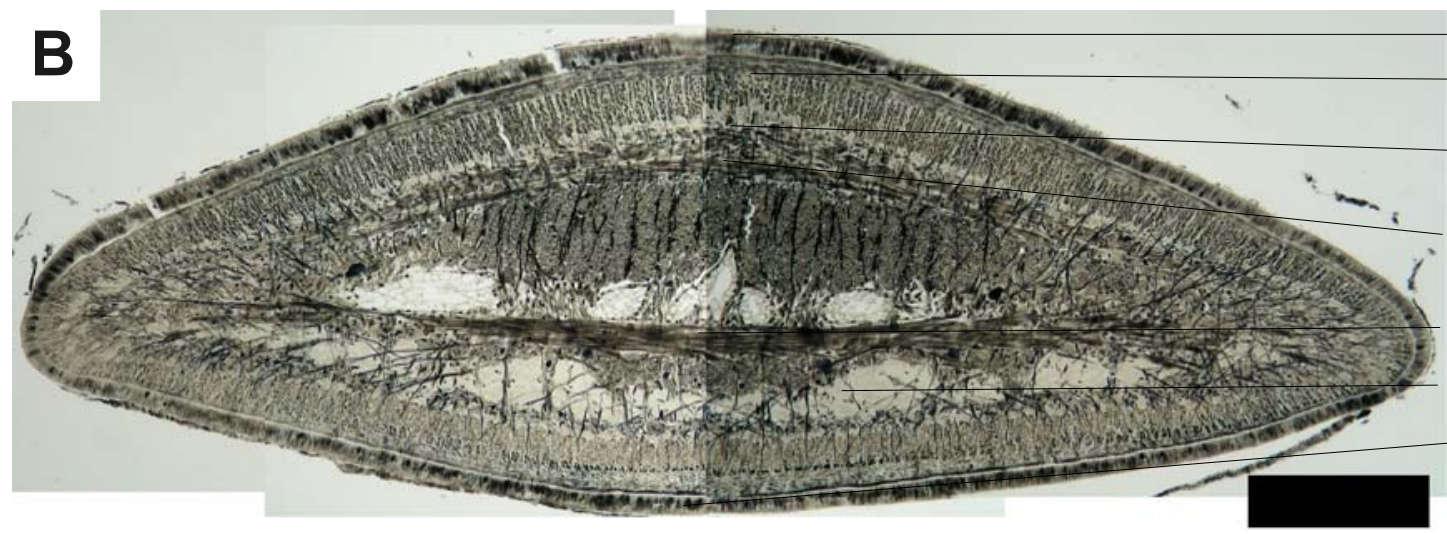
de In dd $\mathrm{sp}$ $\mathrm{sb}$ SC ve
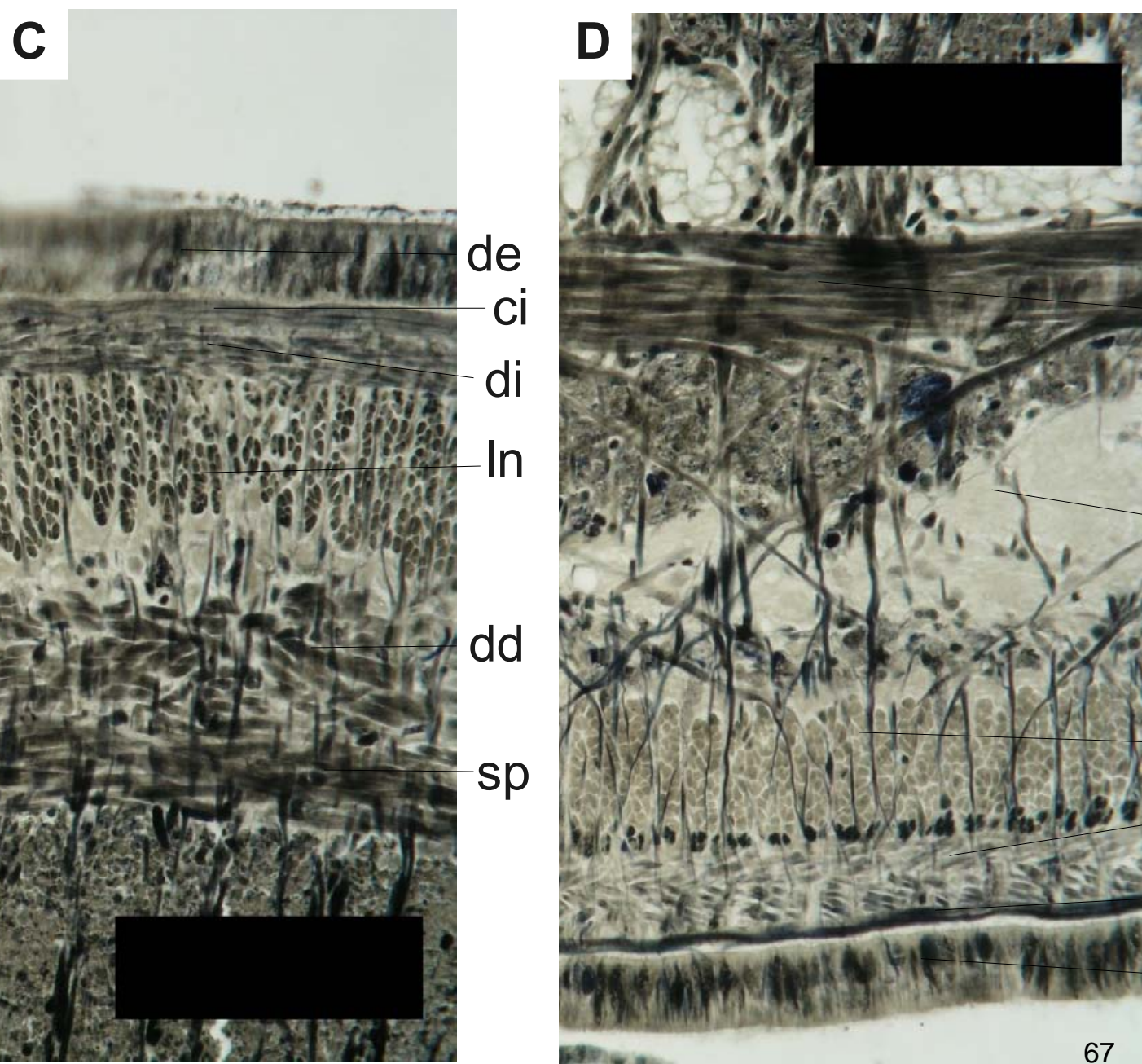

de ci di - In dd $\mathrm{sp}$
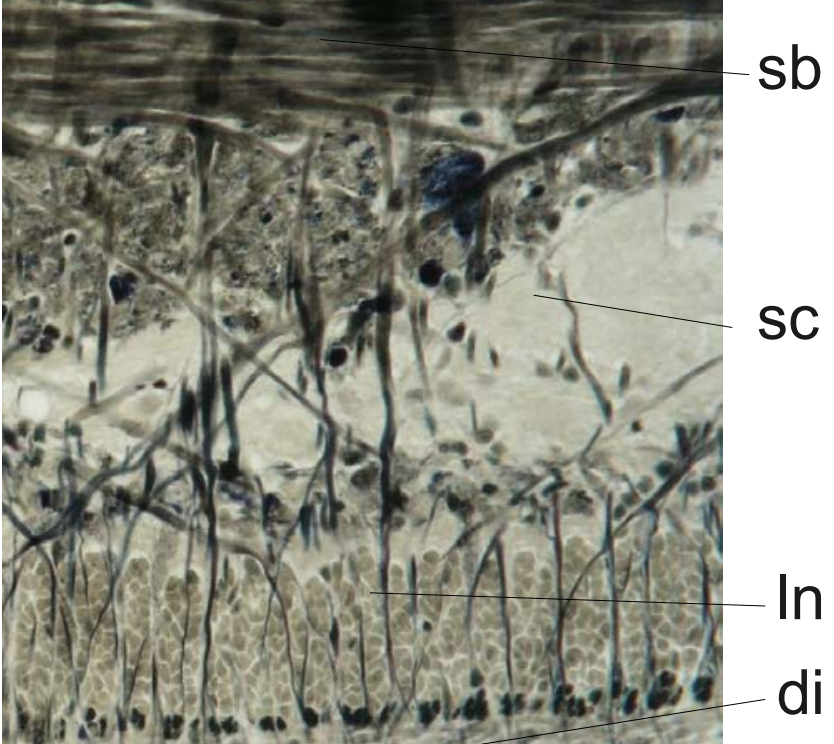

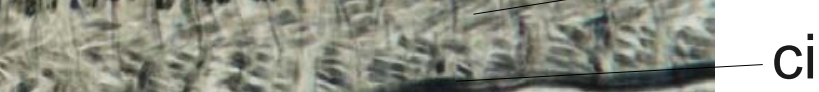

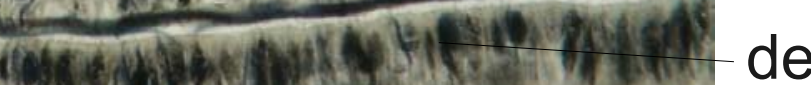

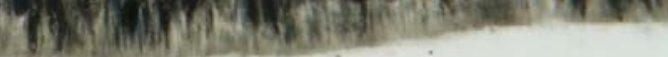



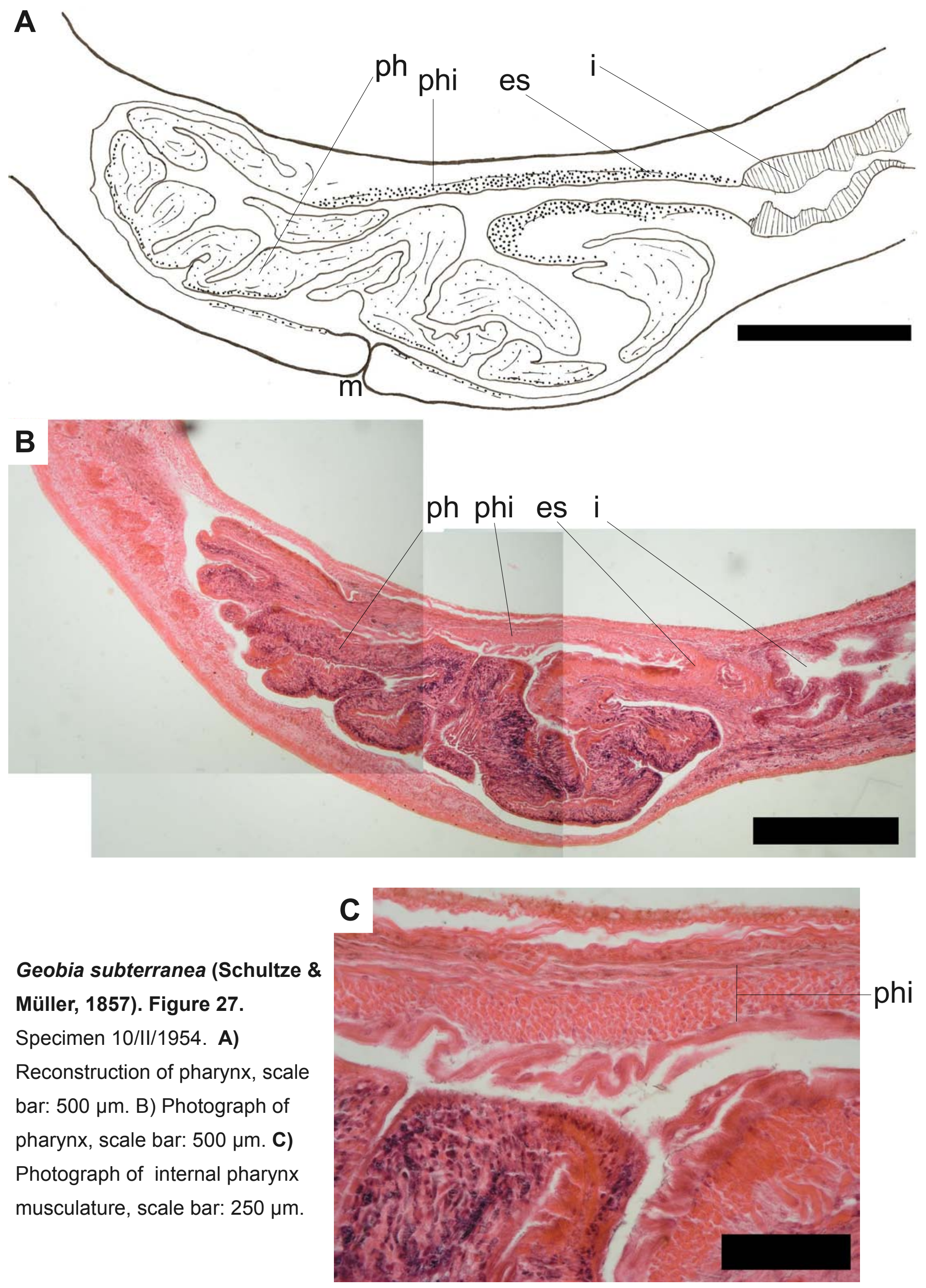

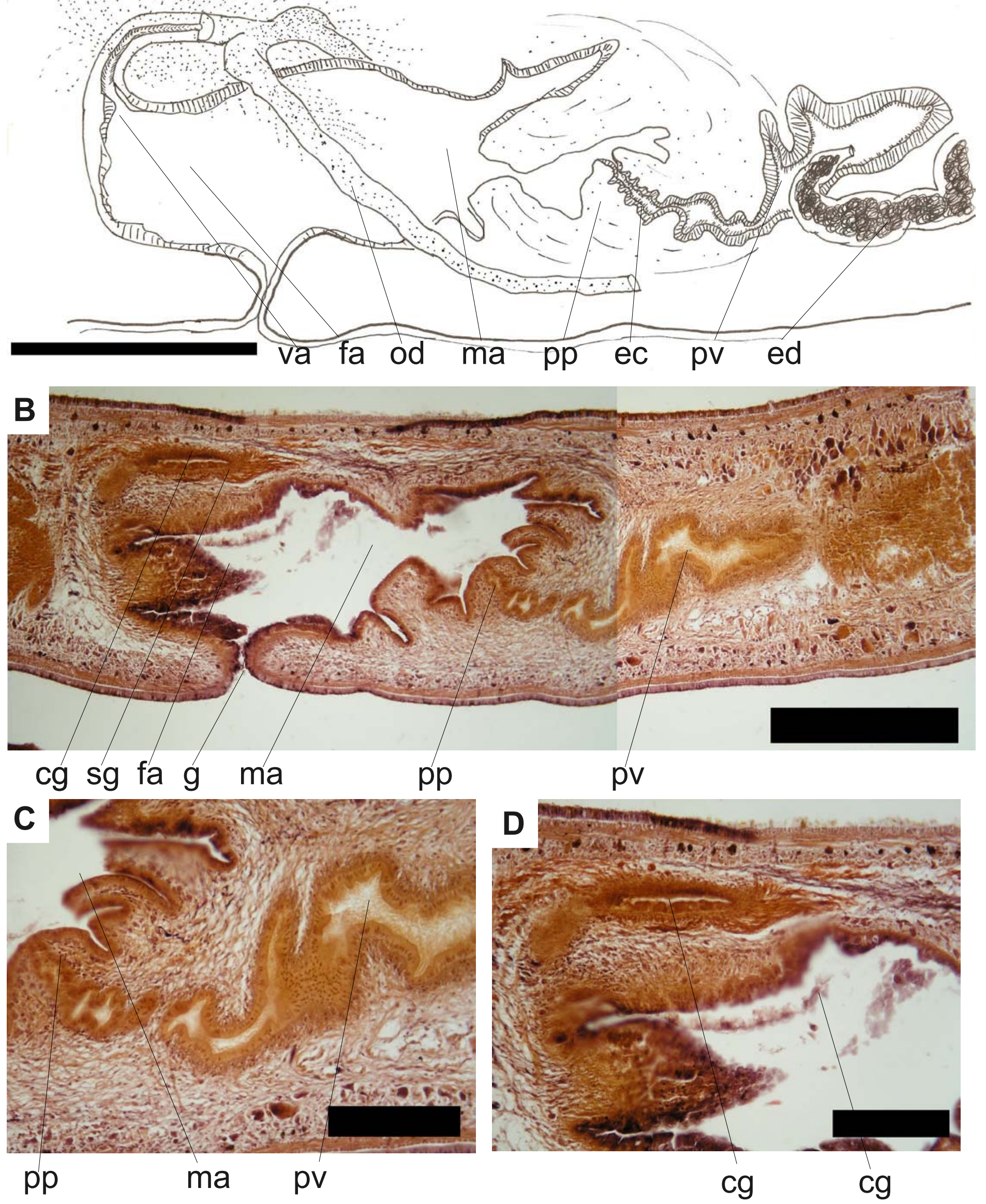

pp ma pv

$\mathrm{Cg}$

$\mathrm{Cg}$

Geobia subterranea (Schultze \& Müller, 1857). Figure 28. Specimen EMF G.s. 12/VII/1954. A)

Reconstruction of copulatory apparatus, scale bar: $500 \mu \mathrm{m}$. B) Photograph of copulatory apparatus, scale bar: $500 \mu \mathrm{m}$. C) Photograph of penis papilla, scale bar: $200 \mu \mathrm{m}$. D)Photograph of female atrium, scale bar: $200 \mu \mathrm{m}$. 


\section{Geoplana vaginuloides (Darwin, 1844)}

\section{SYNONYM}

Planaria vaginuloides n. sp. Darwin, 1844: 244. Rio de Janeiro/Brazil.

Polycelis vaginuloides: Diesing, 1850: 192.

Geoplana vaginuloides: Schultze \& Muller, 1857: 28, 31.

\section{EXAMINED MATERIAL}

FCB 1614: Horizontal sections of anterior part on 5 slides. Horizontal sections of anterior part 2 on 4 slides. Horizontal sections of anterior part 3 on 4 slides. Transversal sections of pre-pharynx on 3 slides. Sagittal sections of pharynx and copulatory apparatus on 9 slides. FCB 1163: Transversal sections of anterior part on 59 slides. Horizontal sections of anterior part 2 on 3 slides. Transversal sections of pre-pharynx on 4 slides. Sagittal sections of pharynx and copulatory apparatus on 8 slides.

\section{MORPHOLOGY}

External Morphology. Sub-cylindric body. Creeping sole wide. Eyes distributed laterally and dorsally. The lateral eyes distribute around the anterior region in a single row, they are elongated, $75-100 \mu \mathrm{m}$ long, resembling a cone (Figure 29B). The dorsal eyes are smaller, spherical in shape, $25-30 \mu \mathrm{m}$ in diameter. Dorsal eyes distributed in one o two rows per side, extending to the posterior tip of the body.

Sensory pits present around anterior tip in a single row, extending no more than the first fourth of body length. Sensory pits consist of simple invaginations of about $25 \mu \mathrm{m}$ deep.

Sub-epidermal musculature. Tripartite sub-epidermal musculature. Longitudinal subepidermal musculature packed in tall bundles of no more than $40 \mu \mathrm{m}$ tall, each containing 1520 fibers. Sub-epidermal musculature not insunk into mesenchyma. In the anterior region the sub-epidermal musculature with same arrangement as in pre-pharyngeal region.

Sub-epidermic secretions. Dorsal side with predominant granular xanthophyll secretions and rhabdites, and in much less degree amorphous basophyll secretions. Glandular ridge absent. In the anterior region no glandular specializations were observed. Rhabdites present only in dorsal surface.

Mesenchymal musculature. Mesenchymal musculature gathered to form 3 muscular layers, and a weak longitudinal muscular tube. Mesenchymal musculature composed of a transversal layer above and beneath the intestine, and dorsal double diagonal. The 
longitudinal musculature of the mesenchym is composed of individual longitudinal singular fibers. The longitudinal muscular tube surrounds the intestinal branches and mixes with its supra and sub-intestinal layers forming a criss cross net above and beneath the intestinal branches. In the anterior region the mesenchymal musculature disappears without additional layers.

Digestive system. The pharynx is occupying the whole pharyngeal pocket (Figure 30A). Mouth located slightly posterior to the half of the pharynx length. Cylindrical pharynx, with dorsal insertion slightly dislocated posteriorly. Esophagus absent. Pharynx pocket musculature composed of circular and longitudinal fibers. The external pharyngeal musculature (Figure 30C) is composed by an external-most thin layer of longitudinal fibers, followed by a circular layer which intermingles with longitudinal fibers. The pharynx mesenchym presents longitudinal and circular fibers, and xanthophyll secretions. The internal musculature (Figure 30B) of the pharynx is composed of two separate muscular layers; a subepithelial circular fiber and an outer longitudinal layer. Intestinal diverticles branching forward from the main anterior canal in a regular alternation pattern.

Central nervous system. Flat nervous plexus, although two nerve chords conspicuous.

Male reproductive system. Testes are globular in shape and measure $200-300 \mu \mathrm{m}$ in diameter. Testes extending backwards in a single row starting from the ovaries region as far back as the pharynx insertion. They are located dorsally above the intestines and under the supra-intestinal transversal mesenchymal layer (Figure 29A). Each testicle communicated with the efferent duct through a thin dorso-ventral channel.

The vasa deferentia run dorsally to the nervous system and dorsally external in relation to the ovovitelline ducts. The vasa deferentia enter the prostatic vesicle separately, in an anterior dorsal angle. Prostatic vesicle absent. The Ejaculatory duct runs in the middle of the penis papilla with a slightly helicoidal course. The ejaculatory duct opens straightly through the sharp tip of the pointed penis papilla. Male atrium composed of longitudinal and circular muscle fibers. The ejaculatory duct is wrapped by a 120-130 $\mu \mathrm{m}$ thick layer of circular musculature. Ejaculatory duct ciliated and $25 \mu \mathrm{m}$ in diameter. Penis papilla huge and very elongate, totally invading the female atrium (Figure 31A). The external musculature of the penis papilla is composed of two thick layers; an outermost circular layer 100um thick and an inner longitudinal layer of $40-50 \mu \mathrm{m}$ thick (Figure 31B). The mesenchym of the penis papilla bears scattered fibers in all directions (Figure 31C).

Female reproductive system. The ovaries are located anteriorly, approximately $8 \mathrm{~mm}$ 
behind the anterior tip. They are globular in shape, but extend anteriorly and posteriorly. The ovaries measure $200 \mu \mathrm{m}$ in diameter and may reach backwards up to $700 \mu \mathrm{m}$. The ovaries are located ventrally above the transversal sub-intestinal mesenchymal musculature, in between the intestinal branches. The oviducts rise and connect to the external posterior portion of the ovaries. Oviducts with reticulate musculature. Oviducts ascending an a $45^{\circ}$ angle just after the gonopore. The two oviducts connect above the female atrium in a somewhat transversal angle and form a common glandular canal of about $800 \mu \mathrm{m}$ long that opens to the female atrium in an anterior and almost horizontal angle, at the posterior end of the female atrium. Vagina placed at top posterior end, opening in an anterior angle (Figure 31D). Female atrium wrapped in circular and longitudinal musculature. Shell glands opening into last portion of the oviducts and common glandular duct. A thick muscular coat wraps the entire copulatory complex. 
A
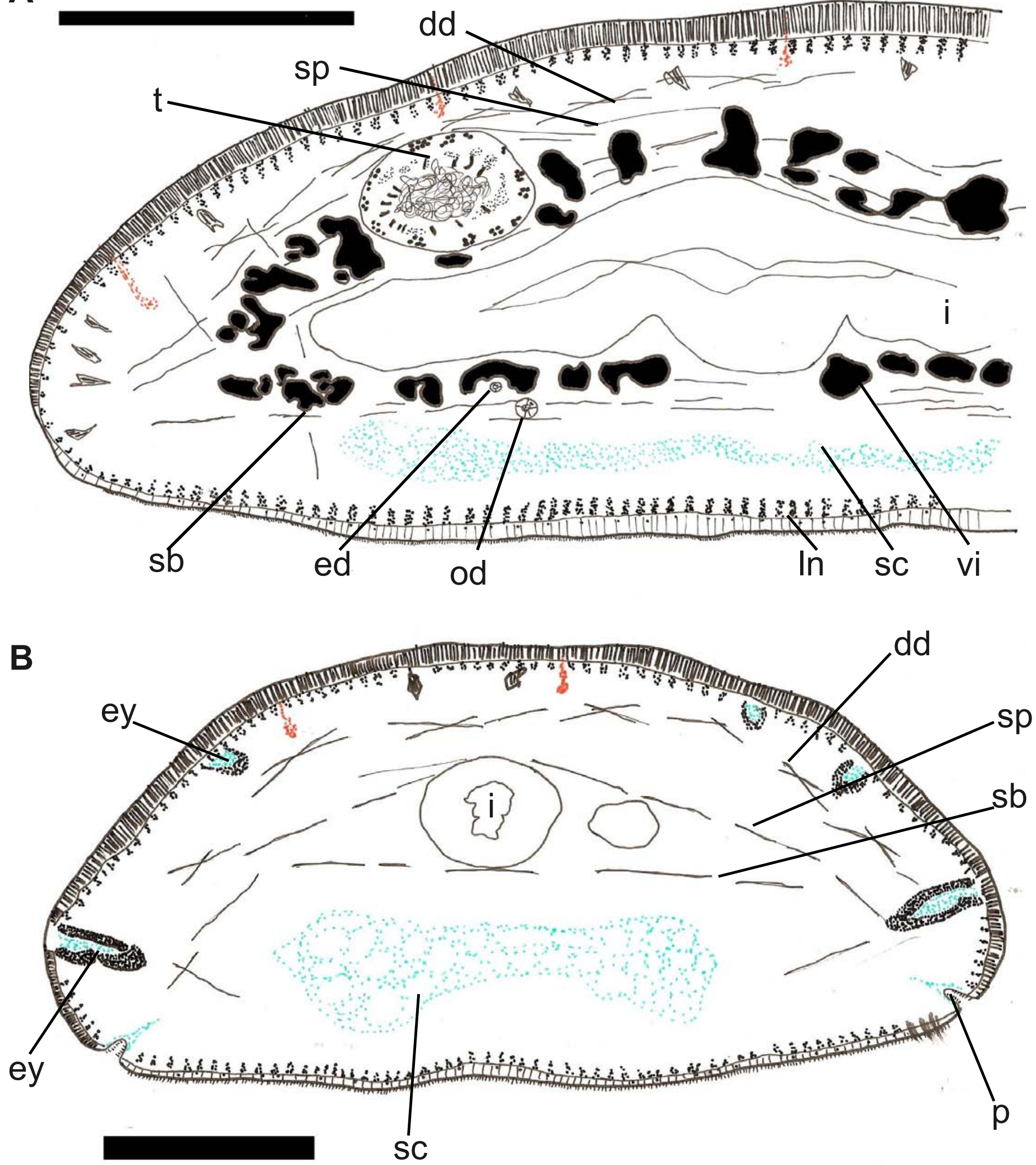

Geoplana vaginuloides (Darwin, 1844). Figure 29. Specimen FCB 1163. A) Reconstruction of transversal section of the pre-pharyngeal region, scale bar: $500 \mu \mathrm{m}$. B) Reconstruction of transversal section of the cephalic region, scale bar: $200 \mu \mathrm{m}$. 

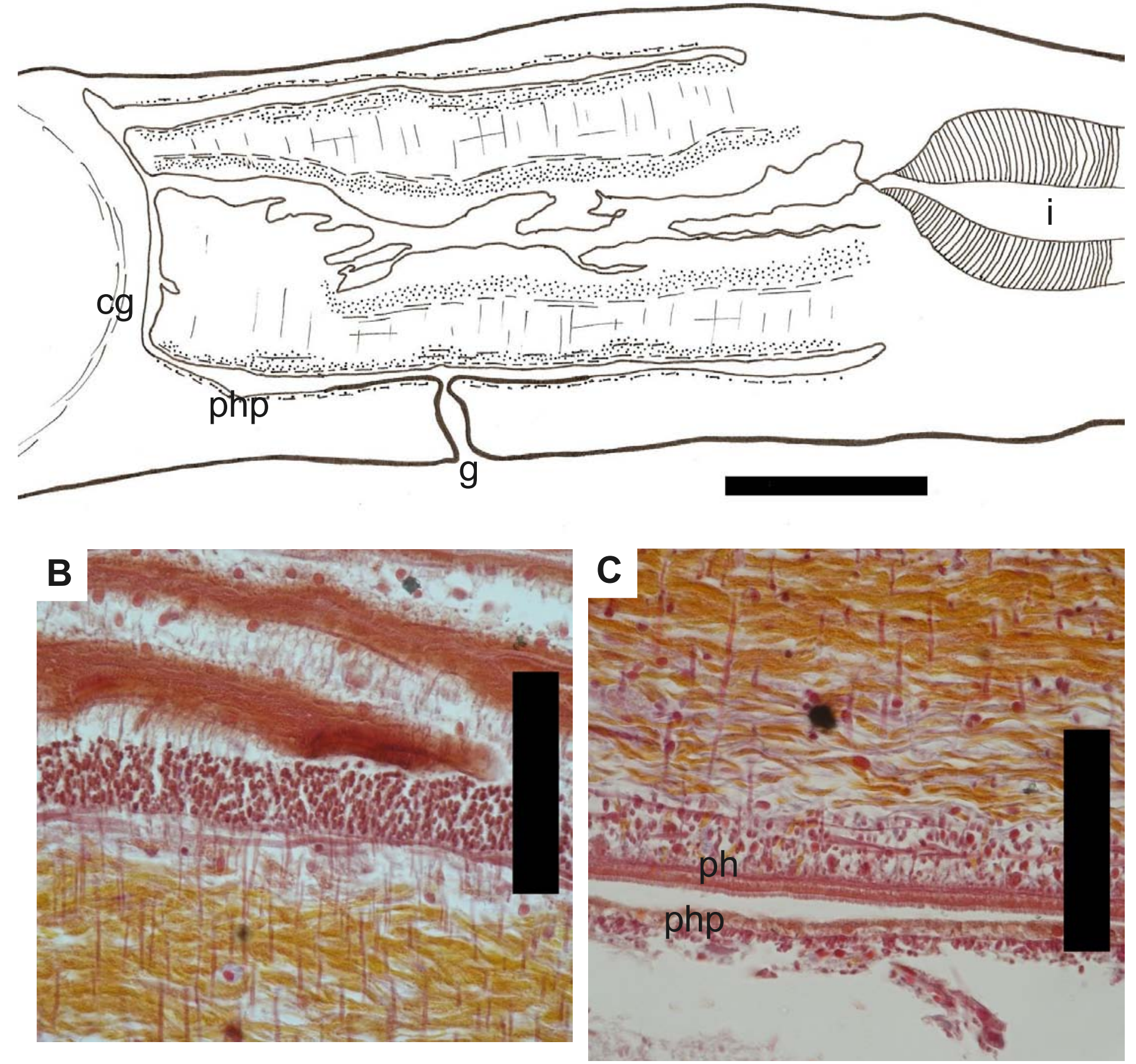

Geoplana vaginuloides (Darwin, 1844). Figure 30. Specimen FCB 1163. A) Reconstruction of the pharynx, scale bar: $500 \mu \mathrm{m}$. B) Photograph of internal pharynx musculature, scale bar $500 \mu \mathrm{m}$. C) Photograph of external pharynx musculature, scale bar: $200 \mu \mathrm{m}$. 

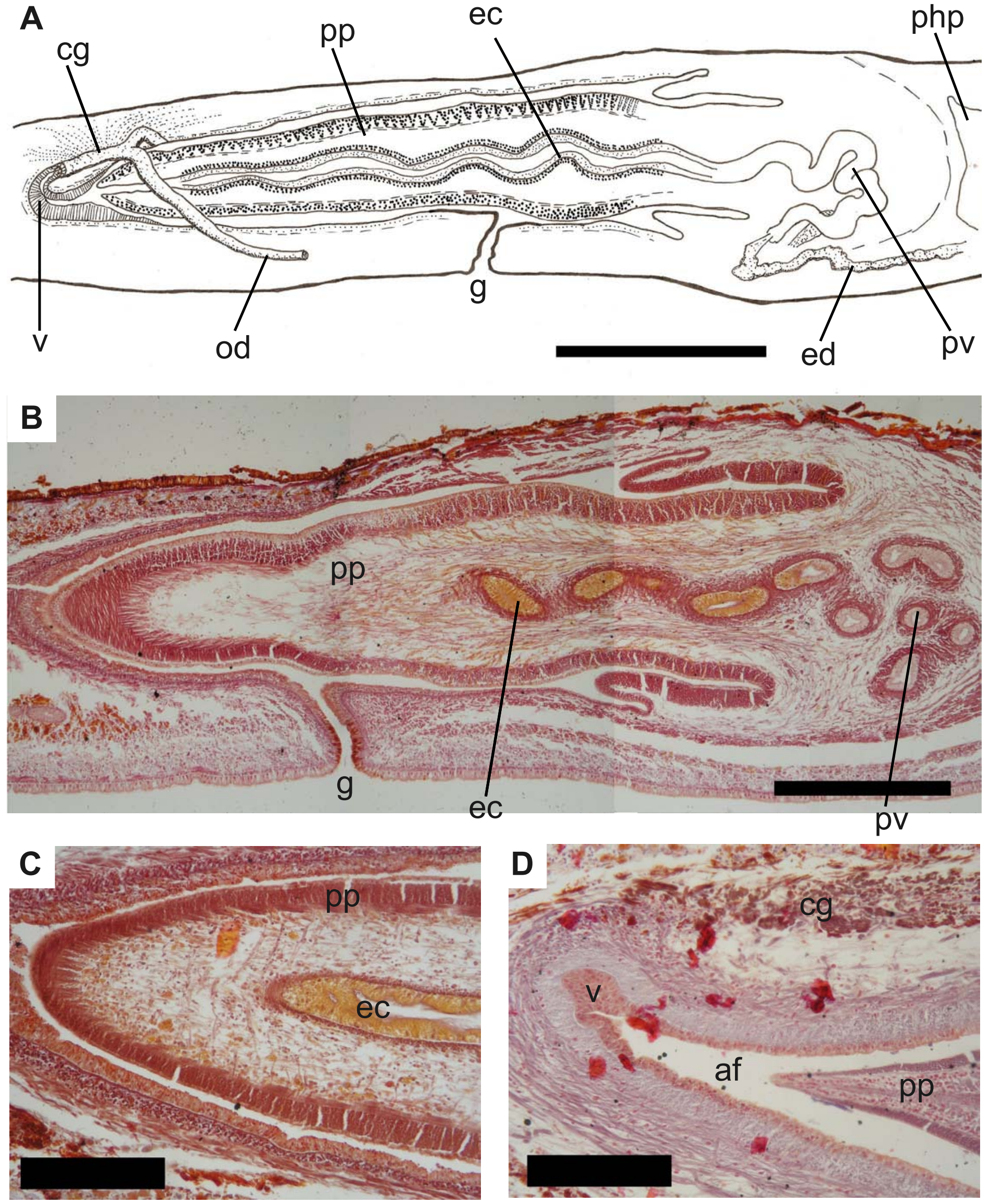

Geoplana vaginuloides (Darwin, 1844). Figure 31. A) Reconstruction of the copulatory apparatus of specimen FCB 1165, scale bar: $1 \mathrm{~mm}$. B) Photograph of copulatory apparatus of specimen of specimen FCB 1165, scale bar: $500 \mu \mathrm{m}$. C) Photograph of penis papilla of specimen FCB 1165, scale bar: $200 \mu \mathrm{m}$. D) Photograph of female atrium of specimen FCB 1614, scale bar: $200 \mu \mathrm{m}$. 


\section{Gigantea gigantea (von Graff, 1899)}

\section{SYNONYM}

Geoplana gigantea n. sp. von Graff, 1899.

\section{EXAMINED MATERIAL}

ZMB 299: Holotype. Transversal sections of anterior part 2, horizontal sections of anterior part 3, sagittal sections of pharynx and sagital sections of copulatory apparatus on 115 slides. Gollmer legt in Caracas, Venezuela.

\section{MORPHOLOGY}

External morphology. Flat body. Creeping sole wide.The eyes surround the anterior tip in single row. Throughout the body the eyes are distributed laterlly, irreguarlly in the first 180 $200 \mathrm{~mm}$ and then spread throughout the dorso. Eyes appear multicellular, measuring $25 \mu \mathrm{m}$ in diameter. Sensory pits surrounding anterior tip in a single row. Gradually separating as they extend backwards. Sensory pits as simple cilliated invaginations $20-25 \mu \mathrm{m}$ deep (Figure $32 \mathrm{C})$.

Sub-epidermal musculature. Tripartite sub-epidermal musculature (Figure 32B). Longitudinal layer packed in bundles (Figure 33D), that in the pre-pharyngeal region measure $80 \mu \mathrm{m}$ ventrally and $50 \mu \mathrm{m}$ dorsally. Sub-epidermal musculature not insunk into mesenchym. In the anterior region no muscular modifications were observed (Figure 32A).

Mesechymal musculature. Mesechymal musculature composed of three layers; transversal sub-intestinal, transversal supra-intestinal and dorsal double diagonal (Figure 33C). All mesenchymal muscular layers composed of single fibres not packed in bundles. Longitudinal mesenchymal musculature absent. In the anterior region no additional mesenchymal muscle layers observed.

Digestive system. Bell shaped pharynx (Figure 33B). Mouth of the specimen indeterminable due to bad preservation state. Esophagus very short or absent. Pharyngeal pouch musculature composed of longitudinal sub-epithelial followed by circular. External pharyngeal musculature composed an outer circular and an inner layer of longitudinal fibbers intermixed with circular. Internal pharyngeal musculature composed of one thick layer of circular fibers intermingled with a few longitudinal ones.

Central nervous system. Nervous system organized in flat nervous plexus. 
Male reproductive organs. Testes located dorsally underneath the mesenchymal transversal supra-intestinal (Figure 33A), and extending in multiple rows as far back as the pharynx insertion. Testes globular and flattened in shape, 200-300 x 400-500 $\mu \mathrm{m}$. The vasa deferentia start to thicken at the level of the pharynx. They ascend almost vertically and connect with the prostatic vesicle. The vasa deferentia split before connecting with the prostatic vesicle (Figure 34A), one reconnects forming an anastomosed opening and the second vas deferens does not reconnect and has two separate opening into the prostatic vesicle. The prostatic vesicle internal to common muscular coat. Prostatic vesicle resembles a horizontally elongated sack (Figure 34C). Penis papilla musculature gathered in bundles (Figure 34B). Penis papilla musculature composed of two muscle layers, an outer layer of circular fibers and an inner layer of thicker longitudinal fibers (Figure 34E). The mesenchym of the penis papilla is scattered with circular fibers. Ejaculatory duct covered by a thick layer, 40 $50 \mu \mathrm{m}$ thick, of intermingled circular and longitudinal muscle fibers (Figure 34D). The ejaculatory duct consists of a broad canal that can measure up to $200 \mu \mathrm{m}$ across. Efferent ducts covered by musculature of reticulated fibbers. Prostatic vesicle musculature composed of reticulated muscle fibers in all directions but predominantly circular. Male atrium musculature composed of outer longitudinal fibers followed by inner circular fibers. Inter-atrial fold absent. The ejaculatory duct canal is completely stuffed with with erythrophyll granular secretions.

Female reproductive organs. Ovaries were not in slides. The ovovitelline ducts approach the copulatory apparatus ventrally. Female atrium gathering fibers in all directions, but predominantly circular fibers. Shell glands opening into terminal portion of the oviducts and common glandular duct. Common muscular coat wrapping the entire Copulatory apparatus. 
A
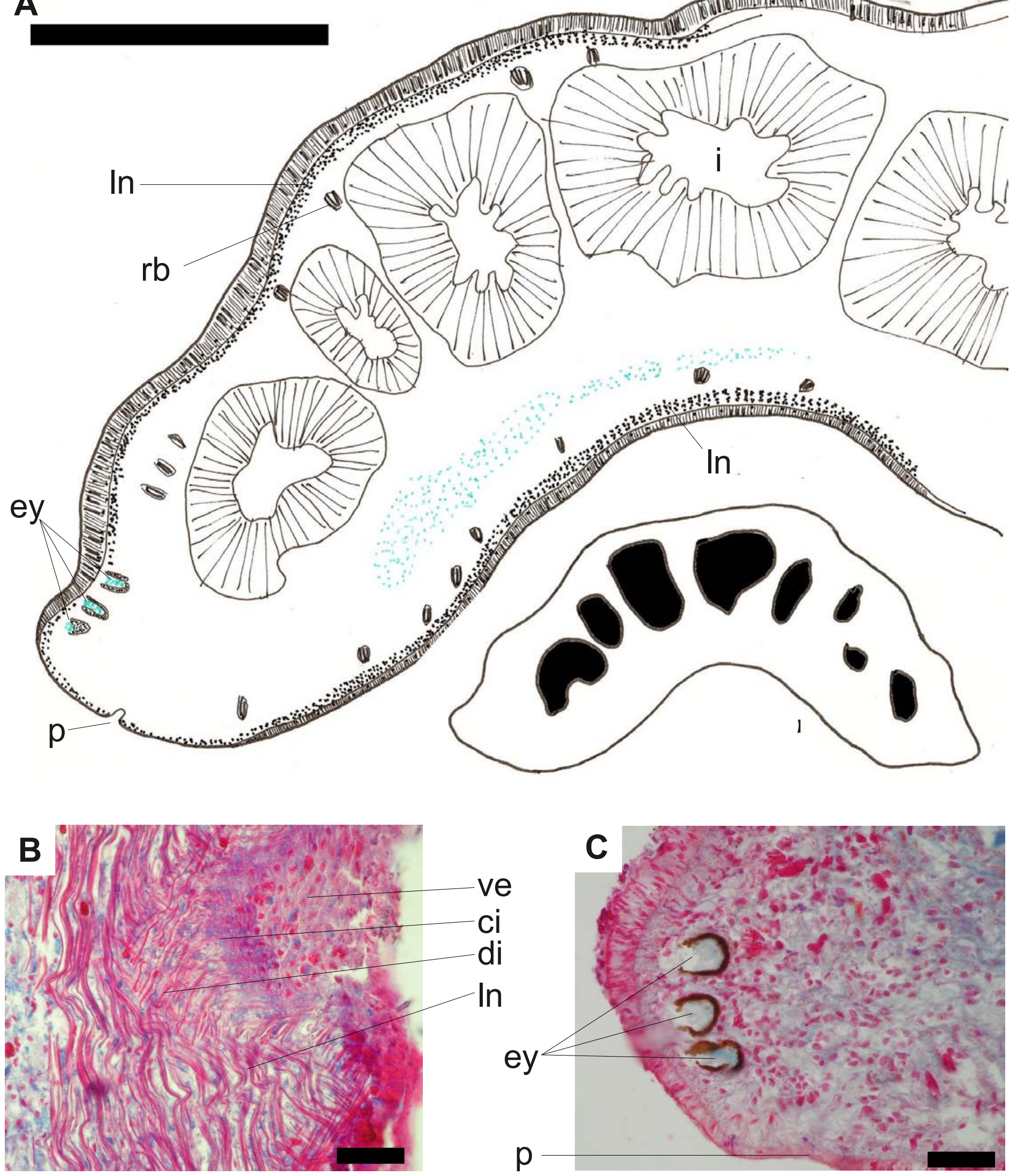

Gigantea gigantea (von Graff, 1899). Figure 32. Holotype. A) Reconstruction of section of anterior part, scale bar: $500 \mu \mathrm{m}$. B) Photograph of ventral sub-epidermic musculature, scale bar: $50 \mu \mathrm{m}$. C) Photograph of eyes and sensory pits from the anterior part, scale bar: $50 \mu \mathrm{m}$. 
A
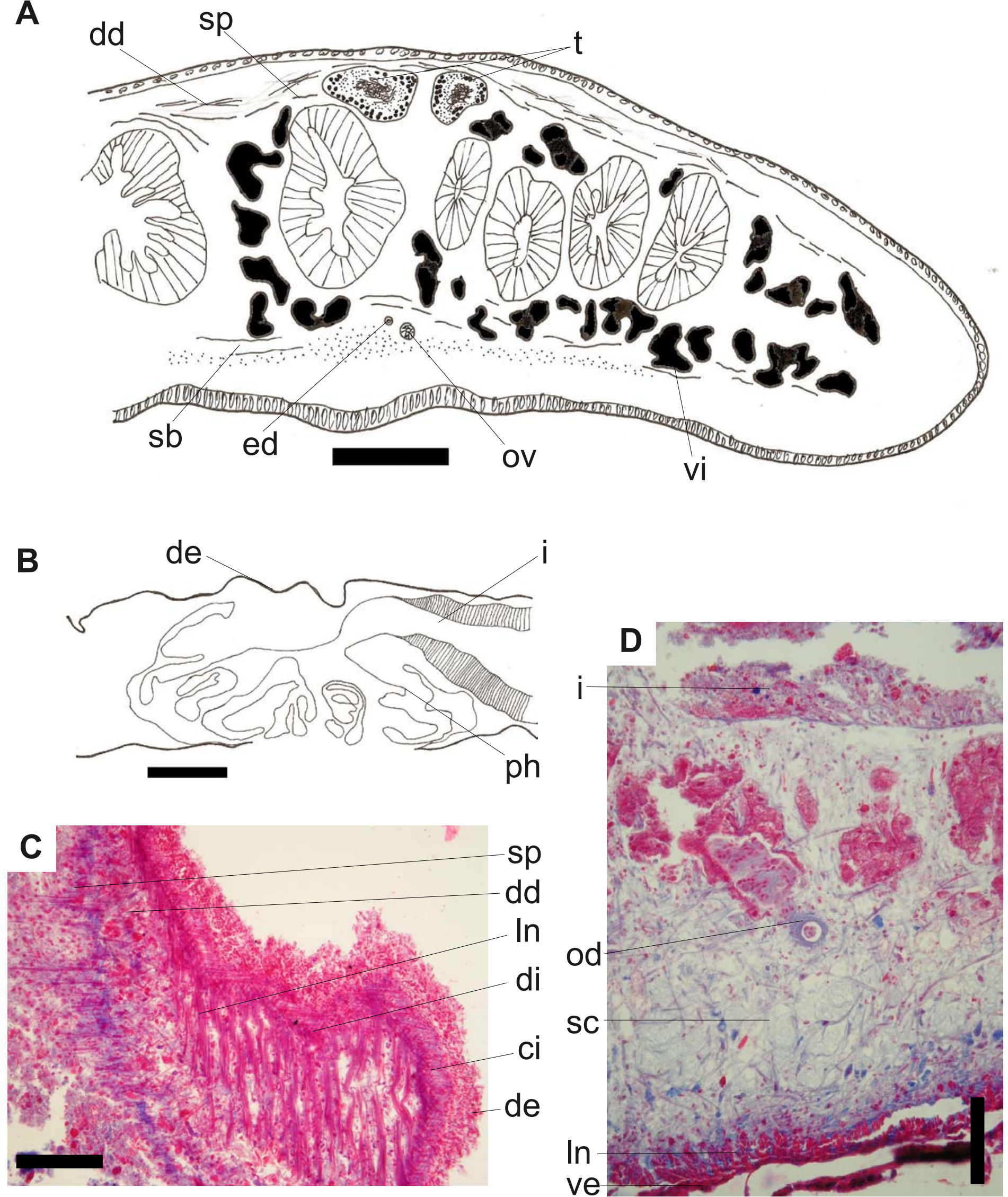

Gigantea gigantea (von Graff, 1899). Figure 33. Holotype. A) Reconstruction of section of the pre-pharyngeal region, scale bar: $500 \mu \mathrm{m}$. B) Reconstruction of section of the pharynx, scale bar: $1 \mathrm{~mm}$. C) Photograph of dorsal sub-epidermic musculature, scale bar $100 \mu \mathrm{m}$. D) Photograph of ventral sub-epidermic musculature, scale bar $100 \mu \mathrm{m}$. 

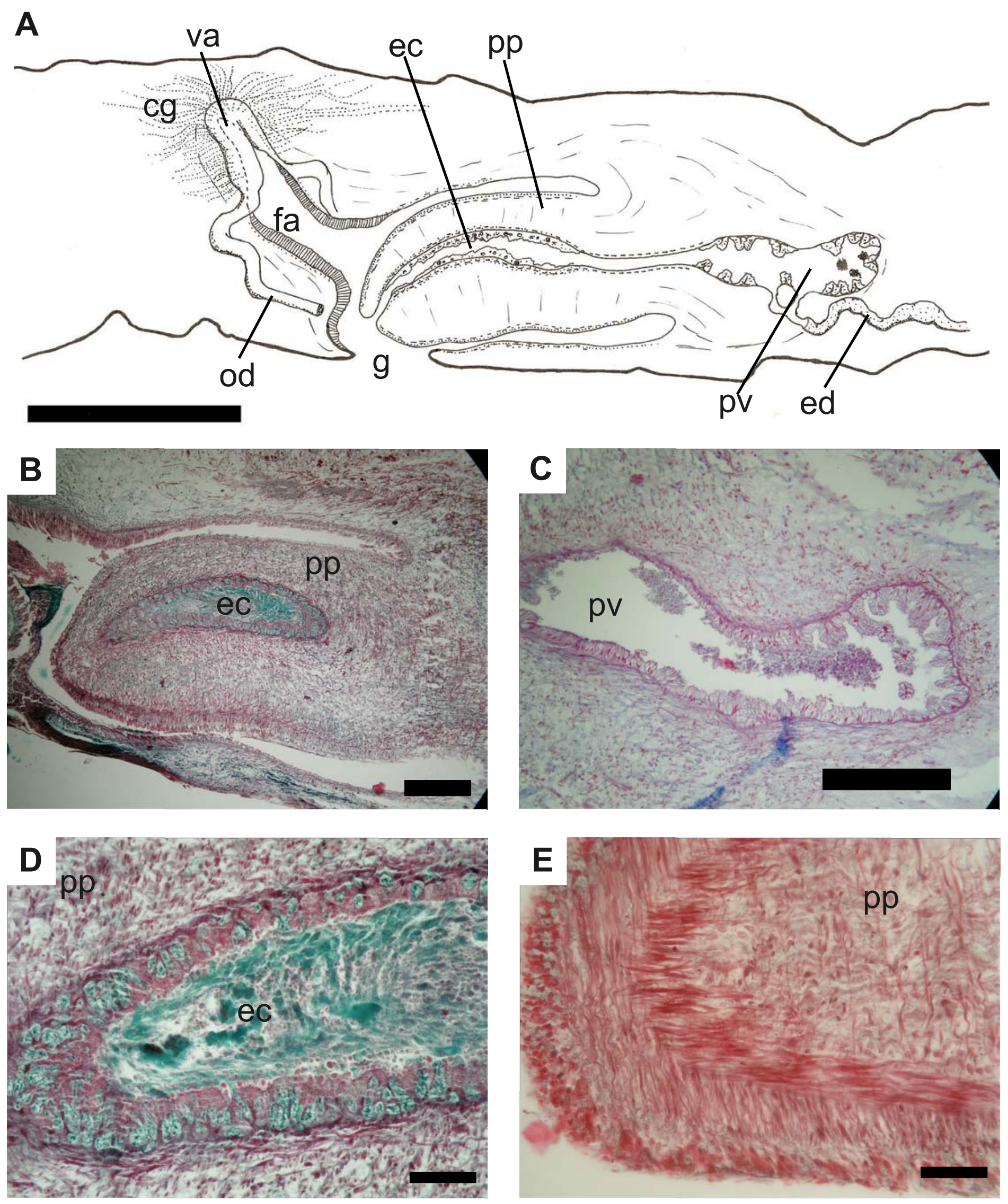

Gigantea gigantea (von Graff, 1899) Figure 34. Holotype. A) Reconstruction of the copulatory apparatus, scale bar: $1 \mathrm{~mm}$. B) Photograph of of penis papilla, scale bar: $200 \mu \mathrm{m}$. C) Photograph of prostatic vesicle, scale bar: $200 \mu \mathrm{m}$. D) Photograph of ejaculatory duct, scale bar: $50 \mu \mathrm{m}$. E) Photograph of penis papilla musculature, scale bar: $50 \mu \mathrm{m}$. 


\section{Gusana cruciata (von Graff, 1899)}

\section{SYNONYM}

Geoplana cruciata von Graff, 1899.

\section{EXAMINED MATERIAL}

EMF G. cruciata: Specimen a: Pharynx and copulatory apparatus, sagittal sections in 10 slides. Specimen b: Pharynx sagittal sections in 9 slides. Anterior part, transversal sections in 6 slides.

\section{MORPHOLOGY}

External morphology. Short leaf-like body. Creeping sole broad, more than half the body width. Eyes distributed on a single row. Sensory pits distributed in a single row around anterior tip. In the more matures specimen the pits are branched bearing different types of diverticles. There may be up to eight sections of pits on the same transverse section (Figure $35 \mathrm{C})$.

Sub-epidermic musculature. Tripartite sub-epidermic musculature. Longitudinal later packed in bundles. The longitudinal layer is totally insunk into the mesenchym, on both the ventral and dorsal surfaces, but more notorious on the ventral side where it reaches the nervous plate. Dorsal musculature much weaker than ventral. The longitudinal layer is crossed by sparse lateral and dorso-ventral fibers. In the head region subcutaneous musculature disappears without modifications (Figure 35B ).

Sub-epidermic secretions. Glandular ridge absent. Head without glandular specializations. Rhabdites sparsely distributed on the dorsal half of the body. They open laterally and dorsally. Dorsal epithelium heavily pigmented.

Mesenchymal musculature. Mesenchymal musculature consists of a transversal subintestinal, transversal supra-intestinal and a double dorsal diagonal. No mesenshymatic muscular specializations were observed in the cephalic region (Figure 35A).

Digestive system. Pharynx occupying most of pharyngeal cavity (Figure 36B). Pharyngeal diverticle absent. Mouth placed at posterior end of pharyngeal pocket. Cylindrical pharynx. Esophagus very short or absent (Figure 36A). Pharyngeal pocket externally composed of circular muscle fibers mainly. External epithelium longitudinally folded, with three muscle layers; a thin on-fiber sub-epithelial longitudinal muscle layer, followed by a circular and then an longitudinal layer (Figure 36D). External muscle layers do not intermix. Internal 
muscle layers intermixed: composed of mainly circular layer crossed in at least three levels of longitudinal fibers (Figure 36C). Pharynx mesenchym crossed by numerous radial fibers.

Central nervous system. Nervous system arranged in a ventral plate.

Male reproductive system. Testes located dorsally underneath transversal supraintestinal mesenchymal layer. Testes pre-pharyngeal. Each testicle communicated with the efferent duct through a thin dorso-ventral channel. The efferent ducts dilate into tortuous spermiducal vesicles which extend posterior to prostatic vesicle then curve anteriorwards and connect to the prostatic vesicle. Prostatic vesicle internal to common muscular coat and is located very close to the pharyngeal pocket (Figure 37B). From the vesicle the ejaculatory duct transverses the center of the penis papilla. Penis papilla small, cylindrical (Figure 37D).

Female reproductive system. Ovaries placed above nervous plate, globular in shape, measuring 180x110 um. Ovovitelline arising from dorsal side of ovaries. Posterior to the gonopore the oviduct turn medially. Shell glands opening into terminal portion of the oviducts and common glandular duct (Figure 37C). At the medial plane they unite forming the common glandular duct that travels dorso-anteriorly. Vagina placed medially and in an horizontal angle (Figure 37A). 

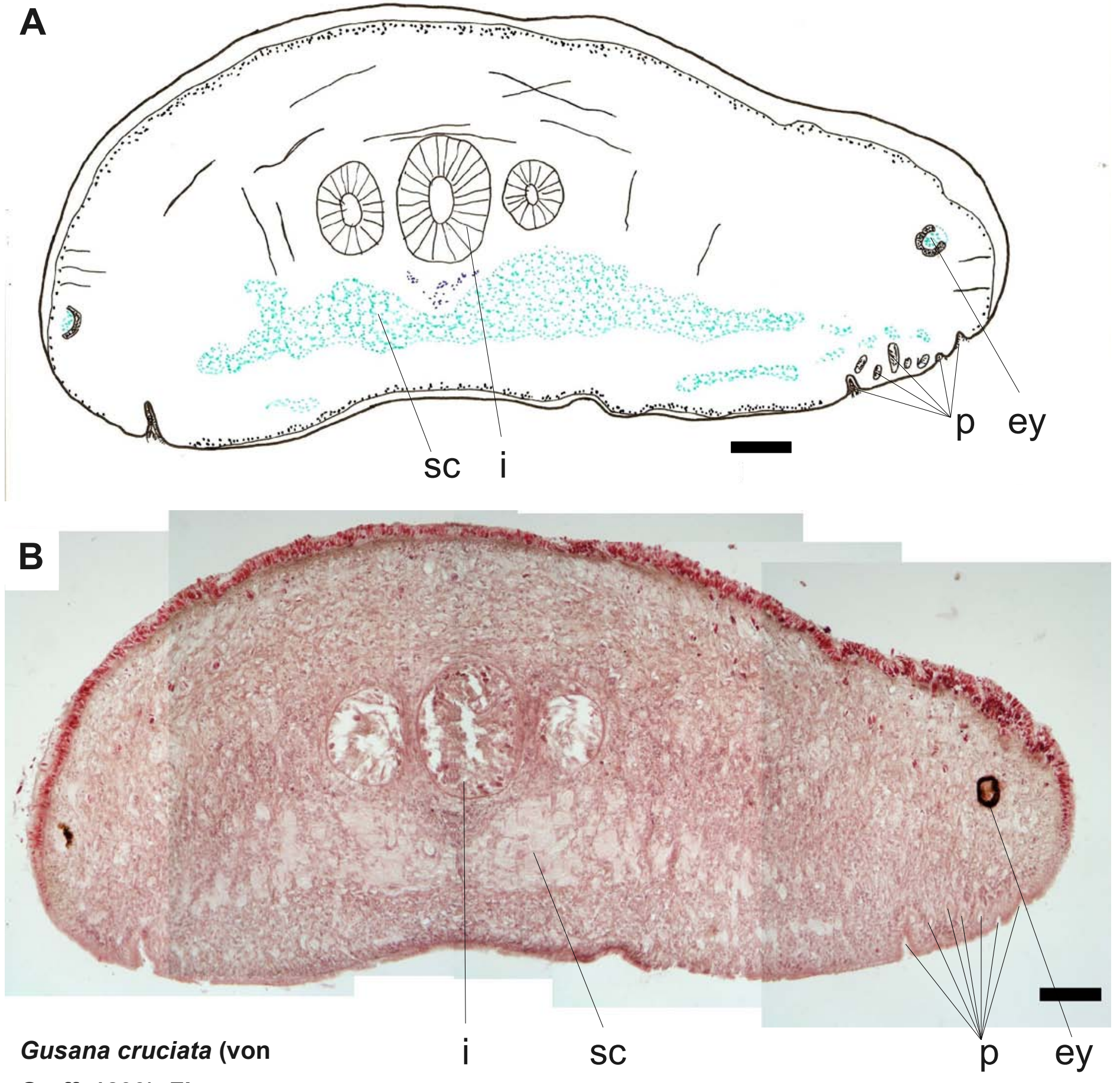

\section{Graff, 1899). Figure}

35. Specimen EMF G. cruciata specimen B.

A) Reconstruction of section of anterior part, scale bar: $100 \mu \mathrm{m}$. B) Photograph of section of anterior part, scale bar $100 \mu \mathrm{m}$. C)

Photograph of sensory pits in section of the cephalic region, scale bar $50 \mu \mathrm{m}$.

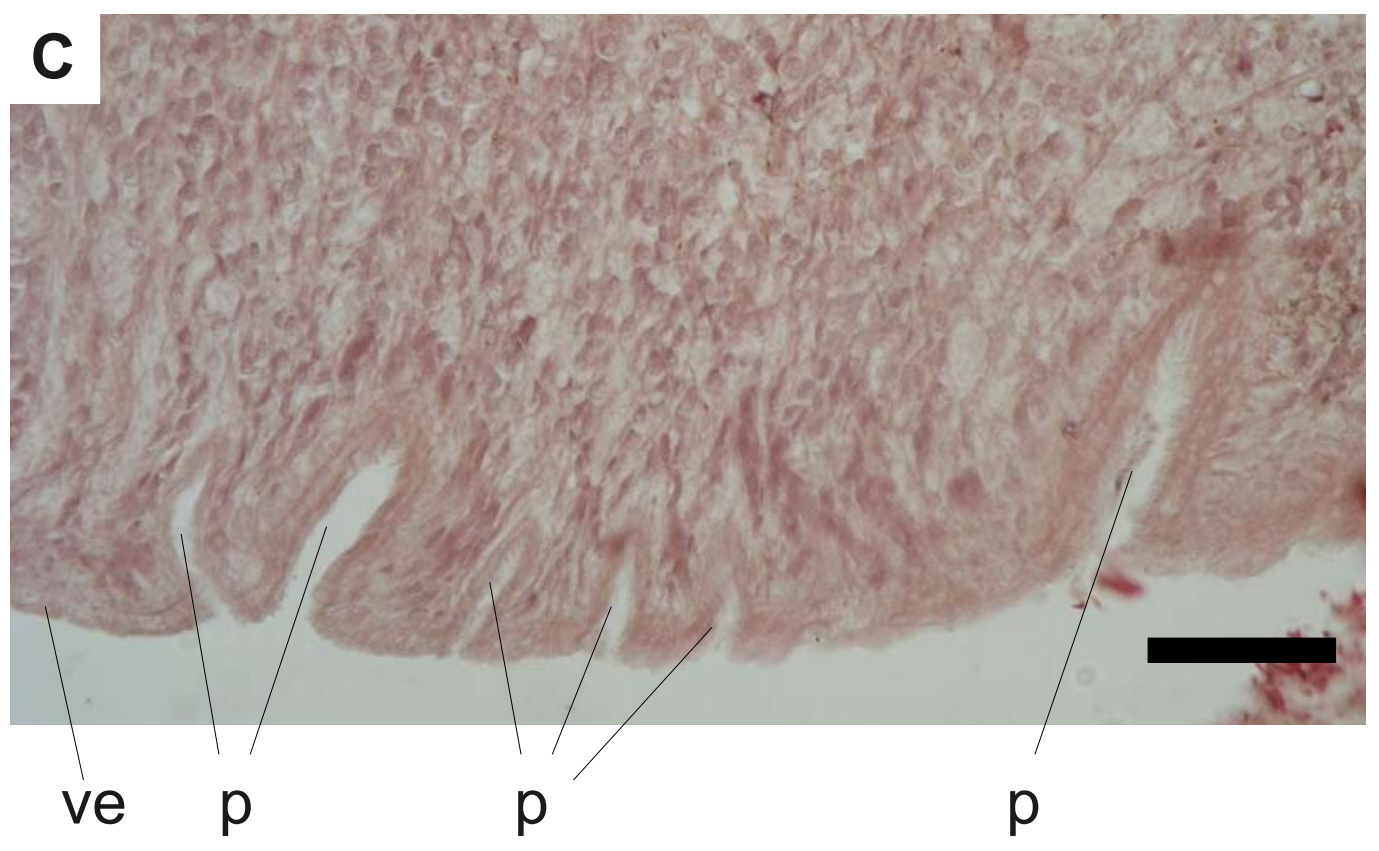



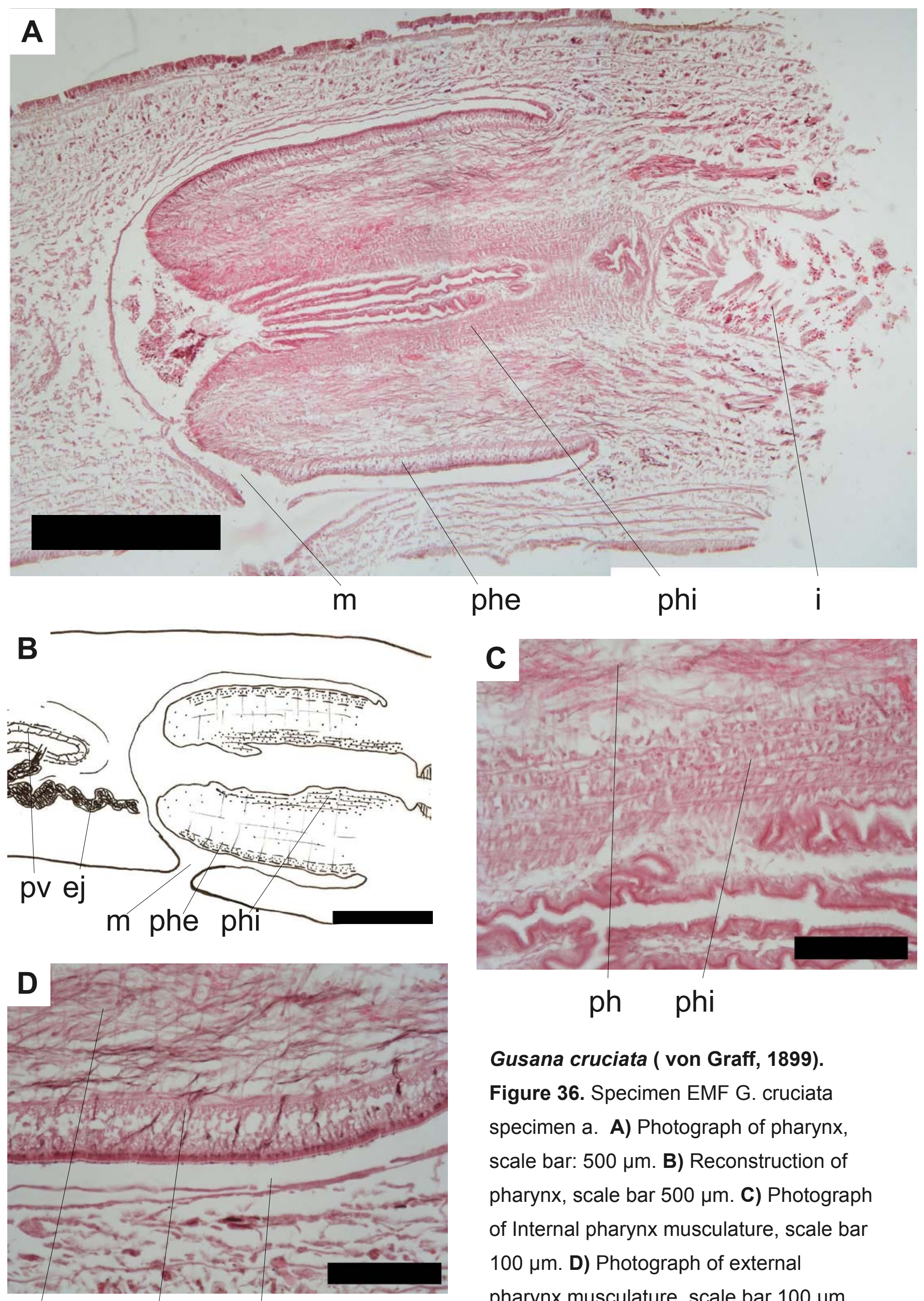
ph phe php

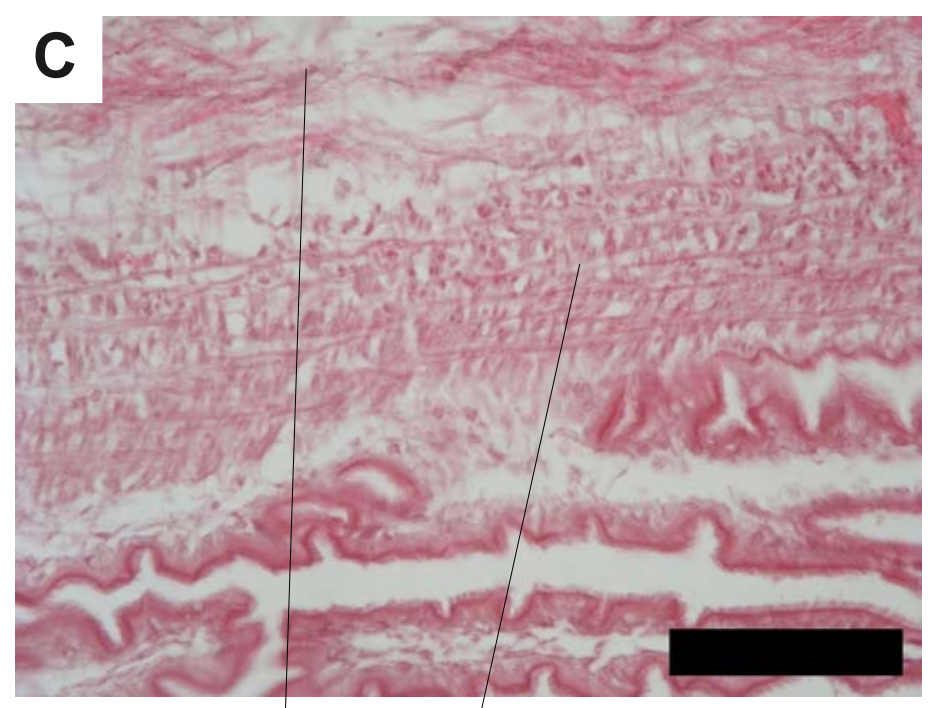

ph phi

Gusana cruciata ( von Graff, 1899).

Figure 36. Specimen EMF G. cruciata specimen a. A) Photograph of pharynx, scale bar: $500 \mu \mathrm{m}$. B) Reconstruction of pharynx, scale bar $500 \mu \mathrm{m}$. C) Photograph of Internal pharynx musculature, scale bar $100 \mu \mathrm{m}$. D) Photograph of external pharynx musculature, scale bar $100 \mu \mathrm{m}$. 

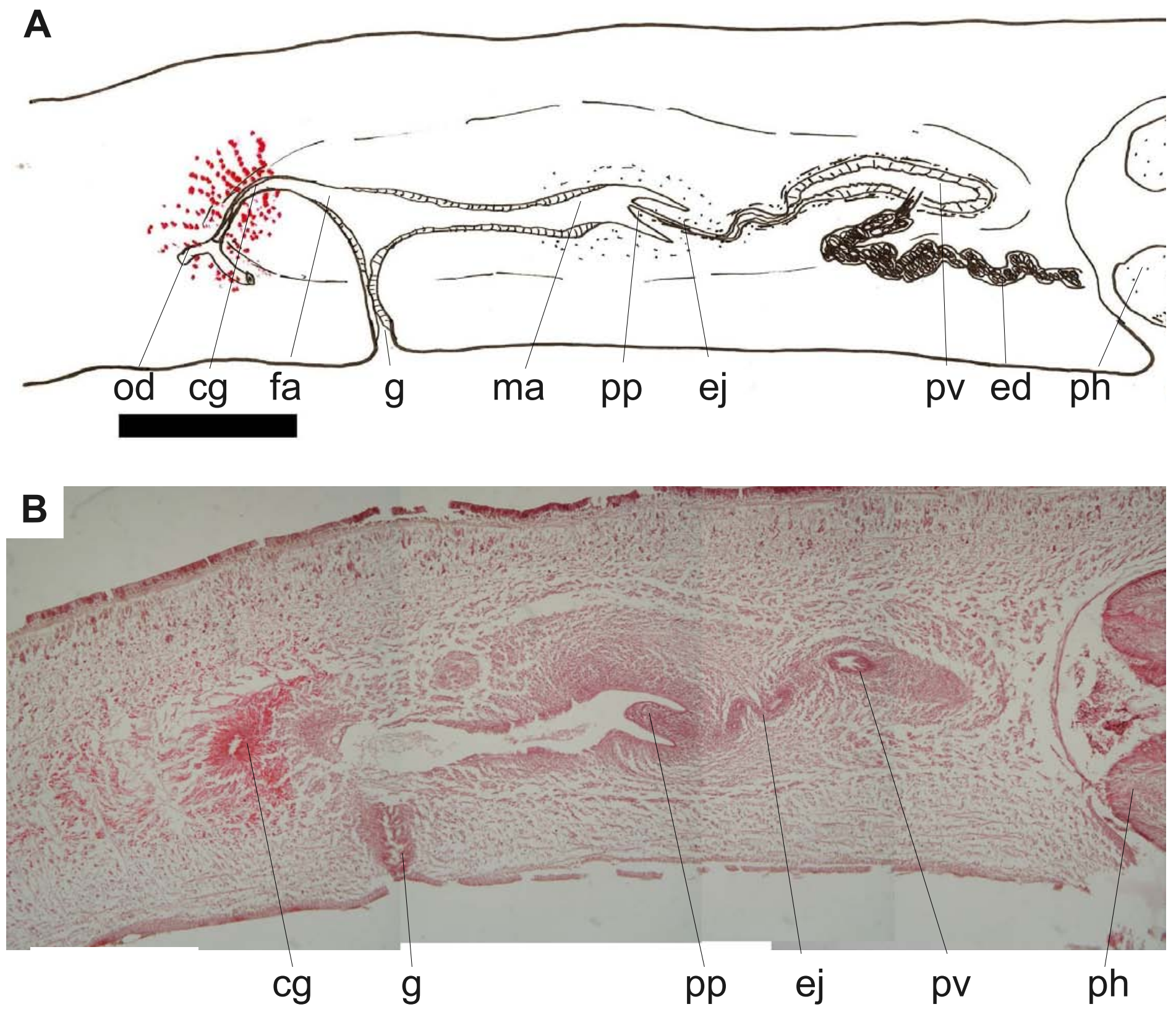

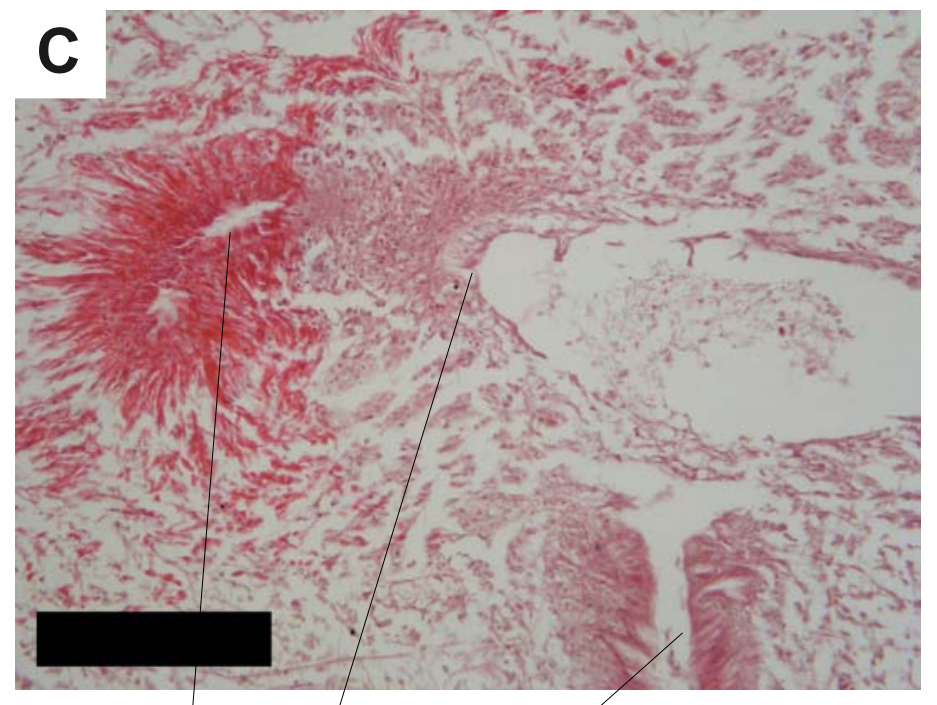

cg fa

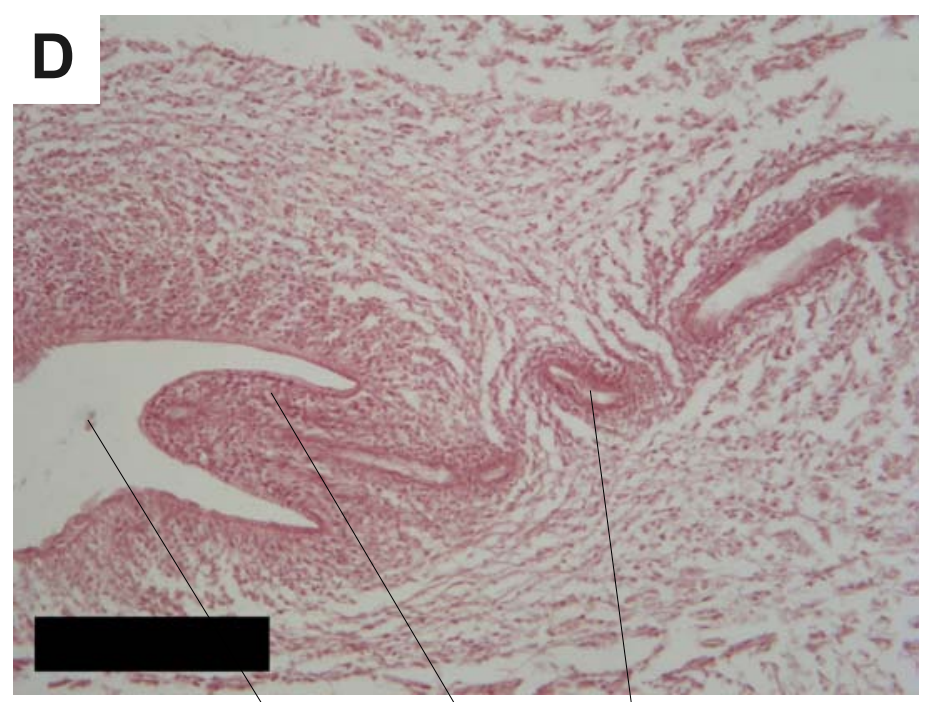

ma pp ej

Gusana cruciata (von Graff, 1899). Figure 37. Specimen EMF G. cruciata specimen a. A)

Reconstruction of copulatory apparatus, scale bar: $500 \mu \mathrm{m}$. B) Photograph of copulatory apparatus, scale bar: $500 \mu \mathrm{m}$. C) Photograph of penis papilla, scale bar $200 \mu \mathrm{m}$. D) Photograph of penis papilla, scale bar: $200 \mu \mathrm{m}$. 


\section{Issoca rezendei (Schirch, 1929)}

\section{SYNONYM}

Geoplana rezendei n. sp. Schirch, 1929.

\section{EXAMINED MATERIAL}

EMF I.r 1951: Copulatory apparatus, sagittal sections on three slides; pharynx, sagital section on 1 slide. EMF I.r 22/X/1952: Anterior part, sagittal sections on 1 slide. EMF I.r 3/X/1952: Anterior part, sagittal sections on 1 slide. EMF I.r 23/V/1952: Anterior part, sagittal sections on 1 slide. EMF I.r 4/XII/1952: Anterior part, transversal sections on 2 slides. Anterior part, horzontal sections on 1 slide. EMF I.r abril/1953: Pre-pharyngeal region, transversal sections on 2 slides. Pre-pharyngeal region, sagittal sections on 1 slide. E Marcus Teresopolis 1952: fullmount of anterior end and pharynx.

\section{MORPHOLOGY.}

External morphology. Sub-cylindric body (Figure 39A). Creeping sole wide, extending about $80 \%$ body width. The head region expanded in a upside-down spoon like fashion. $A$ concave adhesive zone is located on the ventral side of the head, where the epidermis is insunk. Adhesive zone strongly erythrophyll with dense granules. Eyes present in anterior tip in a single irregular row. Behind the neck eyes spread covering most of the lateral region but not extending over the dorso. Sensory pits present as simple invaginations surrounding anterior part in a single row. Extending in only the anterior part.

Sub-epidermic musculature. Tripartite sub-epidermal musculature, packed in bundles (Figure 39B). Stronger ventrally than dorsally. Anteriorly the dorsal sub-epidermal musculature decreases and the ventral musculature (Figure 39C) increases gathering into a cephalic retractor muscle. In transversal sections the sub-epidermic musculature appears as one solid circular bundle composed of many fibers. Cephalic retractor muscle expanding in anterior tip and mixing with mesenchymal transversal and dorso-ventral fibers (Figure 38B).

Sub-epidermal secretions. Cyanophyll glands opening throughout the whole surface of the body. Mainly in through the creeping sole. Granulouse erythrophyll glands abundant dorsally and laterally. Rhabditogen glands abundant dorsally an in a lesser degree ventrally. Large erythrophyll accumulation in the cephalic region before head expansion, placed above the brain and under the intestine, opening to the concave head in the underside. Glandular ridge absent (Figure 38A).

Mesenchymal musculature. Mesenchymal musculature composed of four main layers; 
dorsal double diagonal, transversal supra-intestinal, transversal sub-intestinal and transversal sub-neural. In the pre-pharyngeal region the sub-intestinal appears stronger than the subneural. And in the anterior region the sub-intestinal is the weakest, being the sub-neural and supra-intestinal more developed. Longitudinal mesenchymal musculature absent.

Digestive system. Mouth located at the anterior third of the pharyngeal cavity (Figure 40A). Pharynx occupying 2/3 of pharyngeal cavity. Pharynx cylindrical, with dorsal insertion posterior to ventral insertion. Pharynx highly folded apically. Esophagus short, with same muscular arrangement as internal pharynx muscles (Figure 40C). Pharyngeal pocket composed mainly of circular fibers. External pharynx musculature composed of a thin layer of sub-epithelial longitudinal fibers followed by intermixed circular and longitudinal fibers. Internal pharynx musculature (Figure 40B) composed of sub-epithelial circular followed by longitudinal fibers. Epithelium ciliated.

Central nervous system. Flat plate nervous system type. Brain concentrated just behind anterior tip.

Male reproductive organs. Testes dorsal, located between intestinal branches. Extending from anterior part of the body to the root of the pharynx. Each testicle communicated with the efferent duct through a thin dorso-ventral channel. Efferent ducts running dorsally to the ovovitelline ducts. Efferent duct epithelium squamous, nucleated and non ciliated. Efferent duct with circular musculature. Prostatic vesicle epithelium cubic, non ciliated with vacuoles of erythrophyll secretions. Prostatic vesicle with reticular musculature. Male atrium ciliated with xanthophyll and cyanophyll secretions (Figure 41D). Male atrium musculature circular and longitudinal. Penis papilla folded into irregular shape (Figure 41D).

Female reproductive organs. Ovaries globular in shape, ovovitelline arising from the external side of each ovary, slightly dorsal. Ovaries located ventrally, above the nervous system. Ovovitelline ducts ascending after the gonopore in a vertical angle. Ovovitelline fuse to form a long common glandular duct that curves downwards and opens directly to the vagina. The vagina is positioned at the posterior end of the female atrium. Vaginal musculature composed of reticulate muscle fibers. Female atrium very thin and long cavity extending horizontally (Figure 41A). Musculature composed of circular and longitudinal fibers. Ovovitelline ducts composed of reticulate muscular arrangement. Shell glads opening into terminal portion of oviducts and into the common glandular duct (Figure 41C). Common muscular coat wrapping both atriums, and part of efferent ducts. 
rb i de sc ln sb sn gz vi sp ey
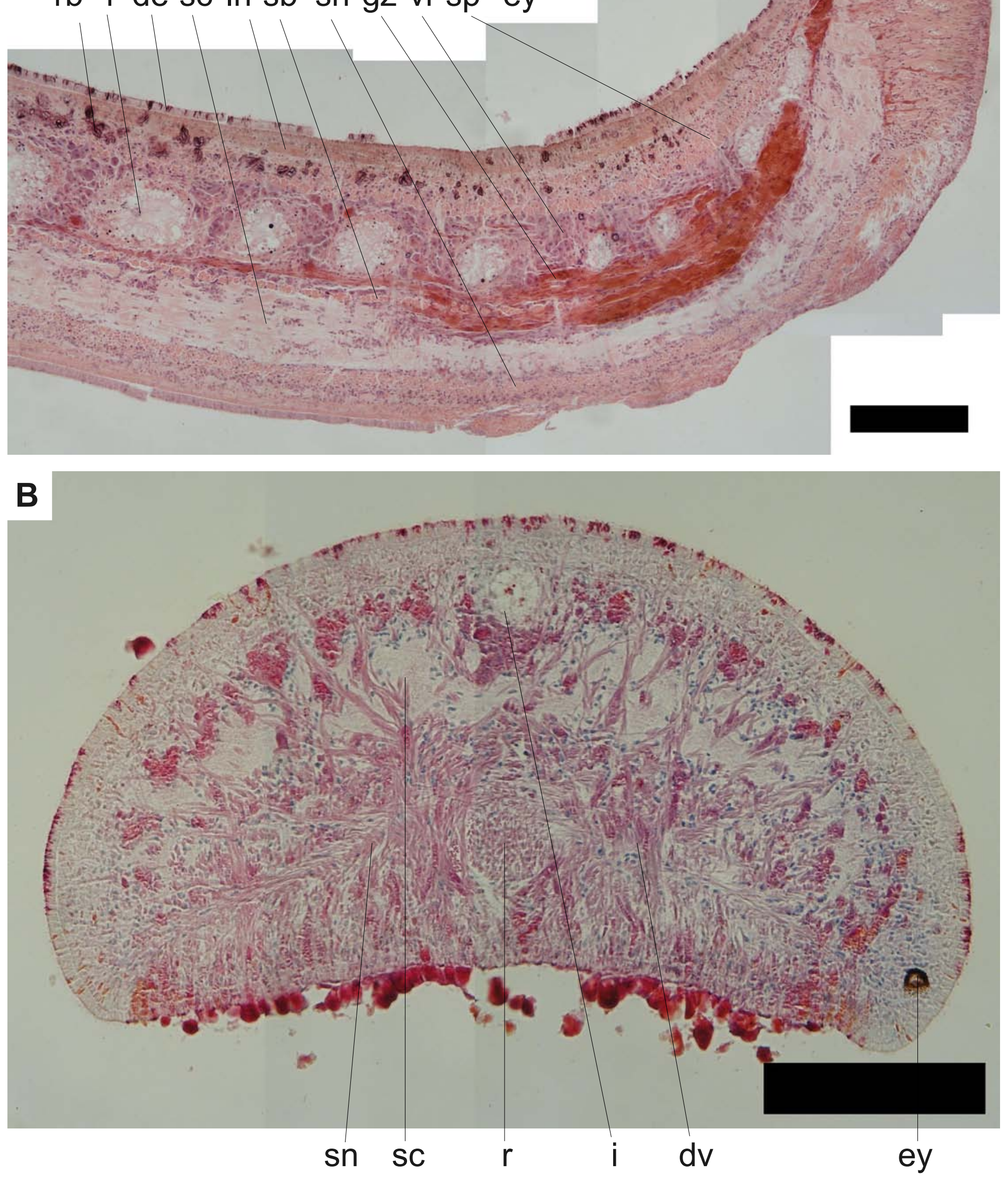

Issoca rezendei (Schirch, 1929). Figure 38. A) Photograph of sagittal section of anterior part of specimen EMF I.r. 22/X/1952, scale bar: $200 \mu \mathrm{m}$. B) Photograph of dorsal sub-epidermal musculature of specimen EMF I.r. 23/V/1952, scale bar: $200 \mu \mathrm{m}$. 
A

A dd

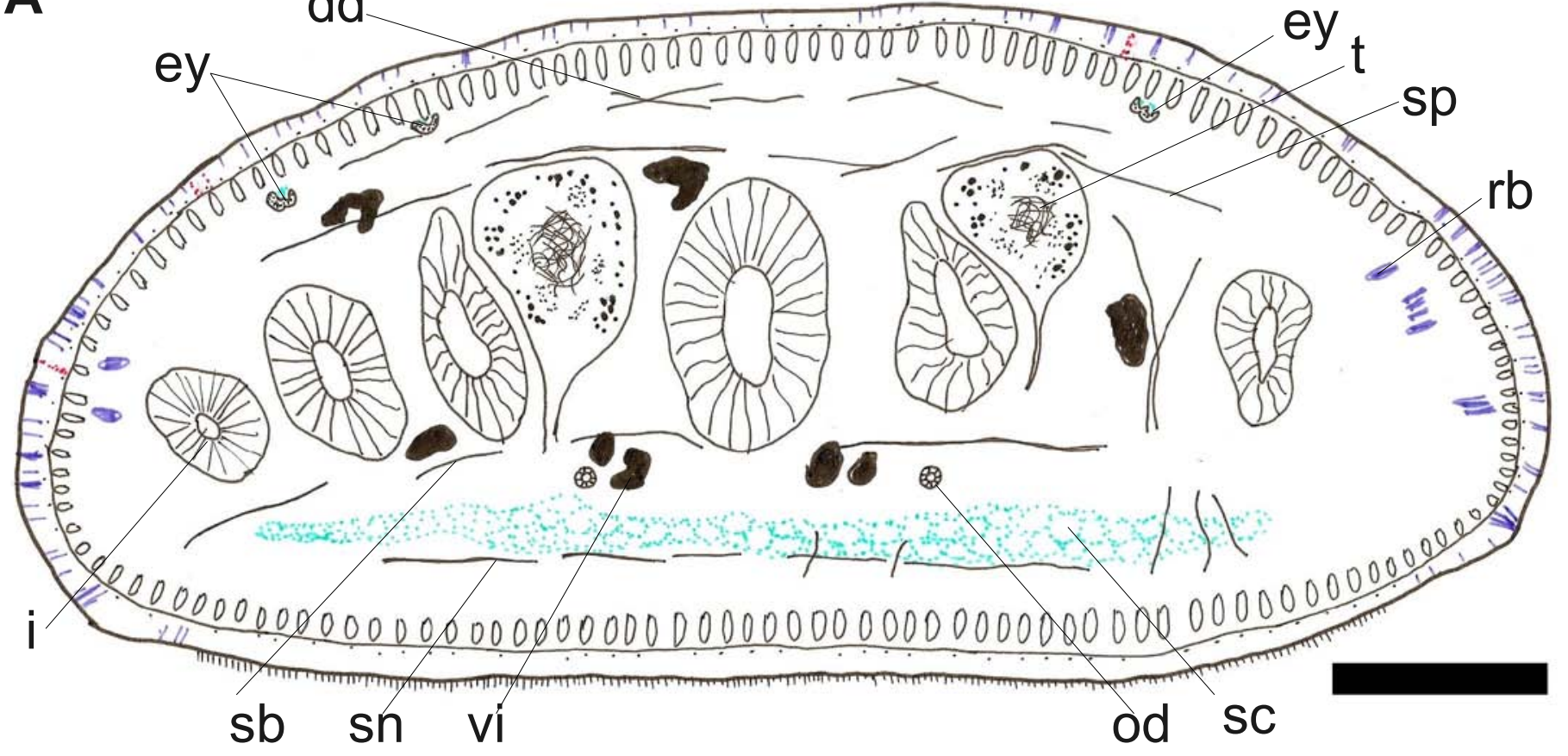

\section{Issoca rezendei}

(Schirch, 1929).

Figure 39.

Specimen EMF I.r. 1951. A)

Reconstruction of pre-pharyngeal

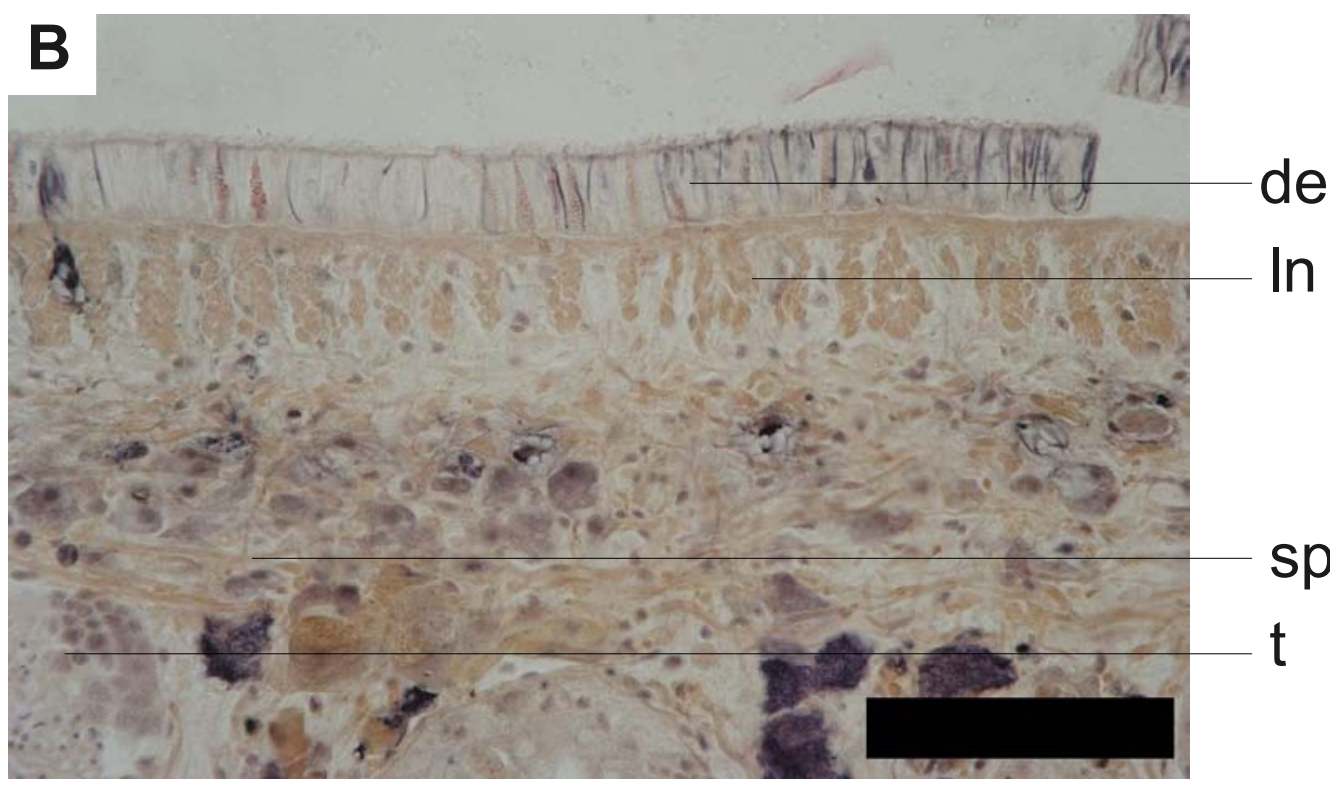
section, scale bar: $250 \mu \mathrm{m}$.

B) Photograph of dorsal subepidermal musculature, scale bar: $100 \mu \mathrm{m}$.

C) Photograph of ventral subepidermal musculature, scale bar: $100 \mu \mathrm{m}$.

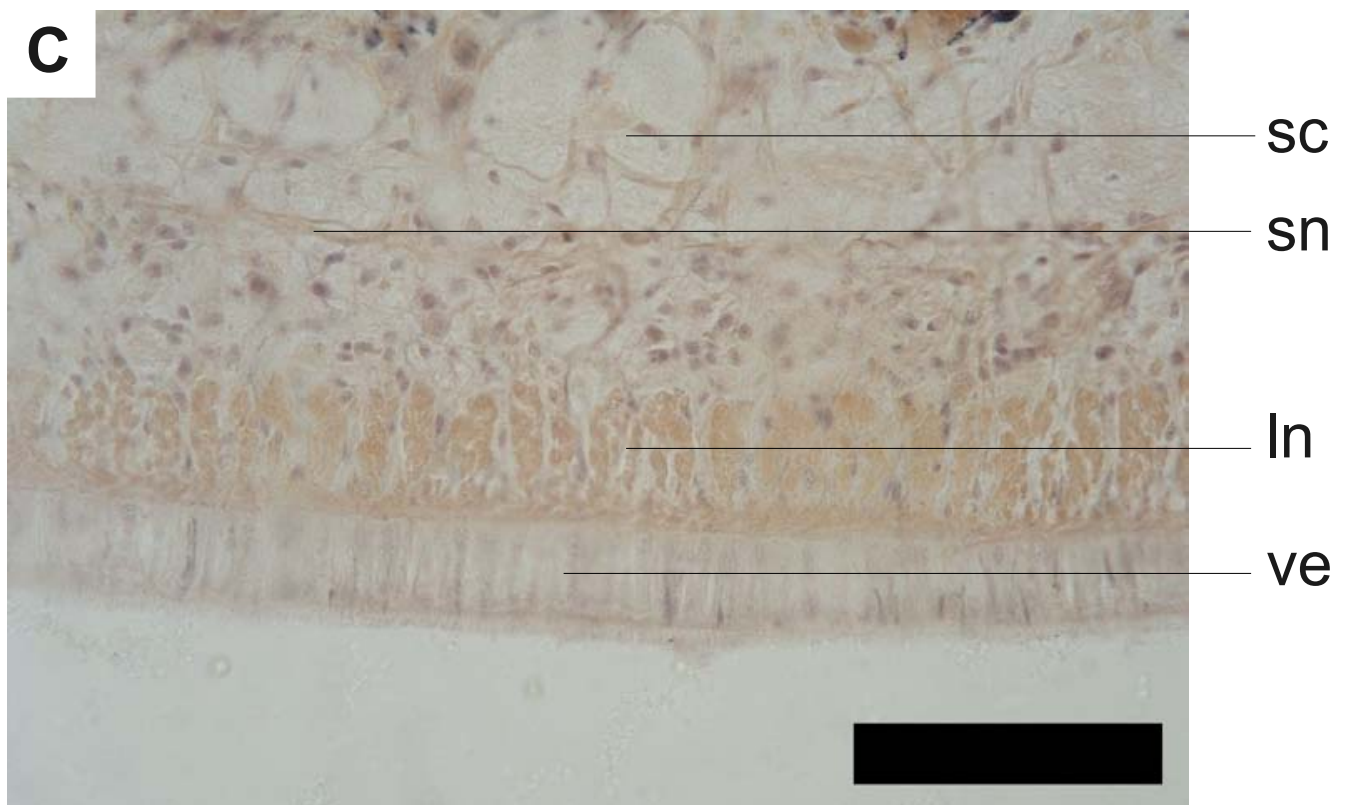




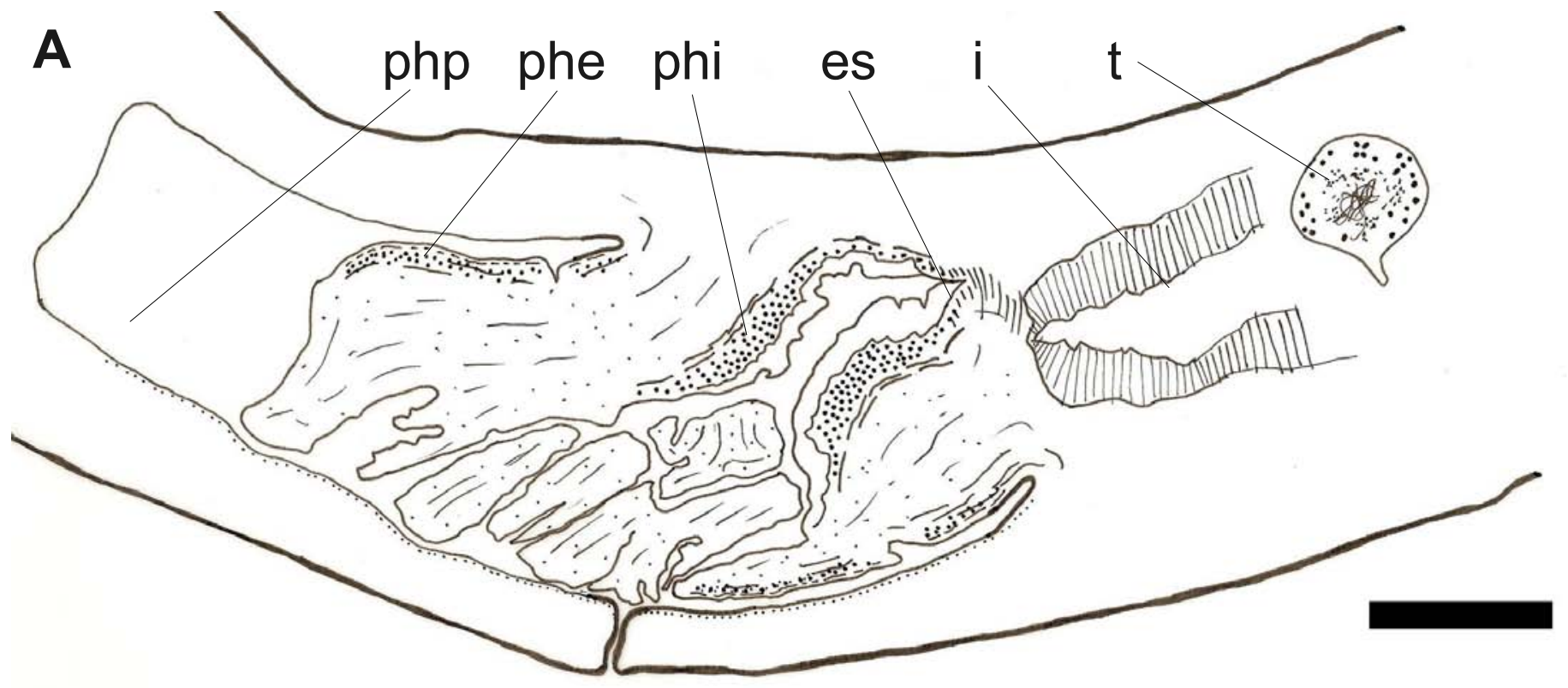

Issoca rezendei (Schirch, 1929).

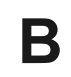

Figure 40. EMF I.r. 1951. A)

Reconstruction of pharynx, scale bar: $500 \mu \mathrm{m}$. B) Photograph of internal pharynx musculature, scale bar: $50 \mu \mathrm{m}$. C) Photograph of pharynx, scale bar: $500 \mu \mathrm{m}$.

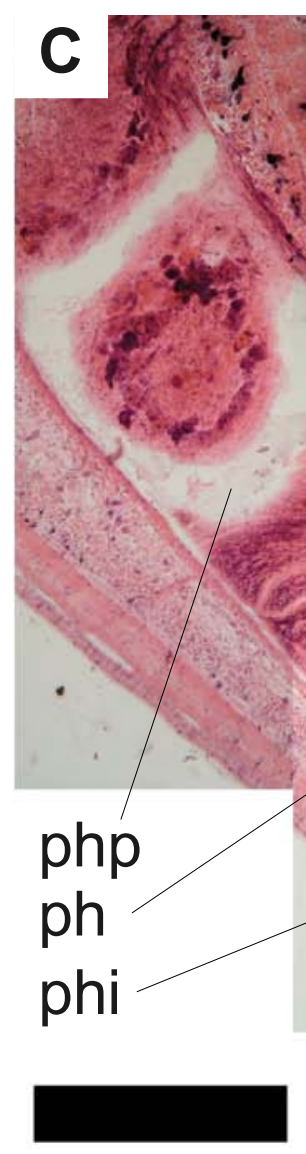

\section{Phi: circular Phi: longitudinal}



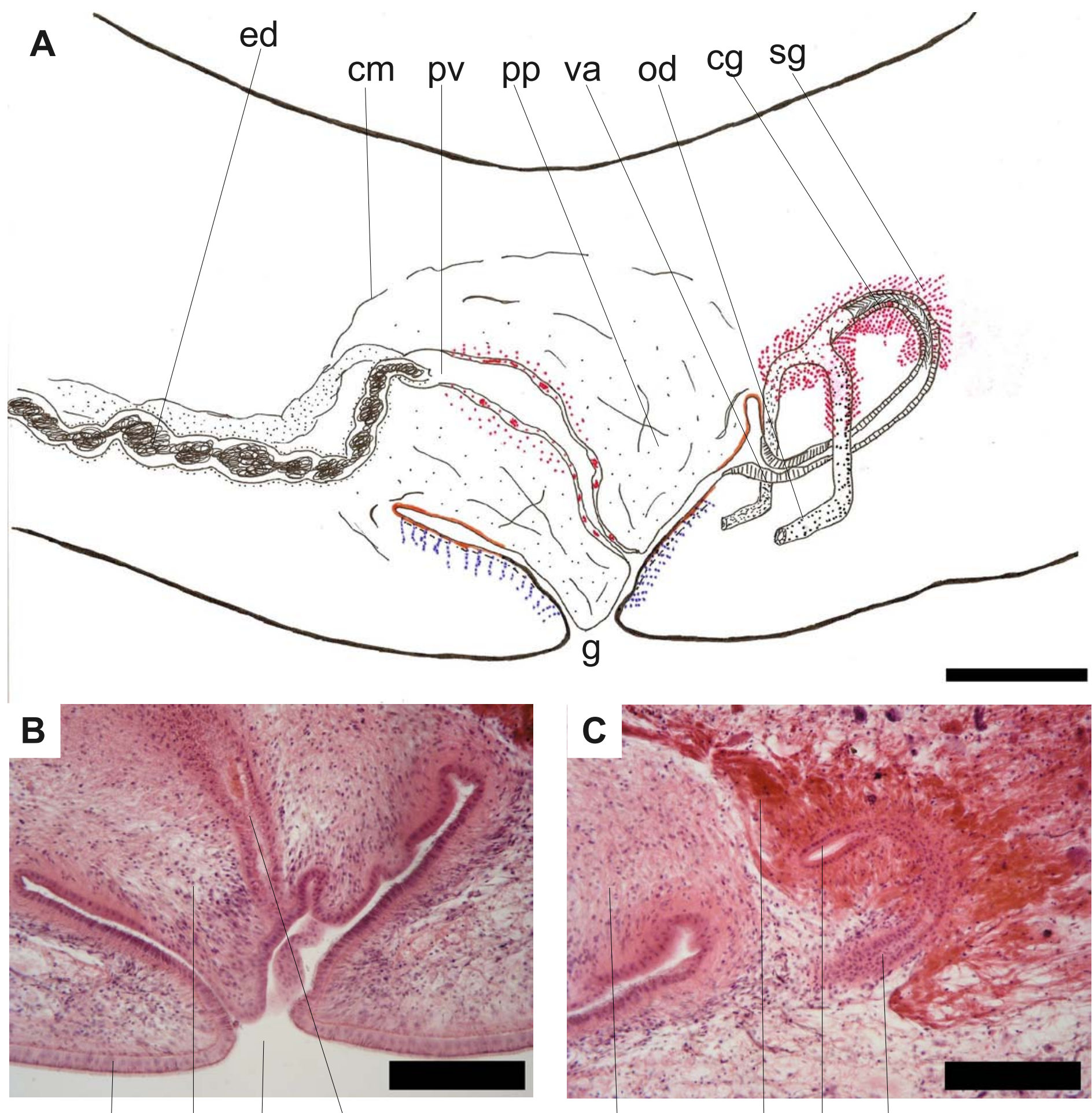

ve pp $g$ ec
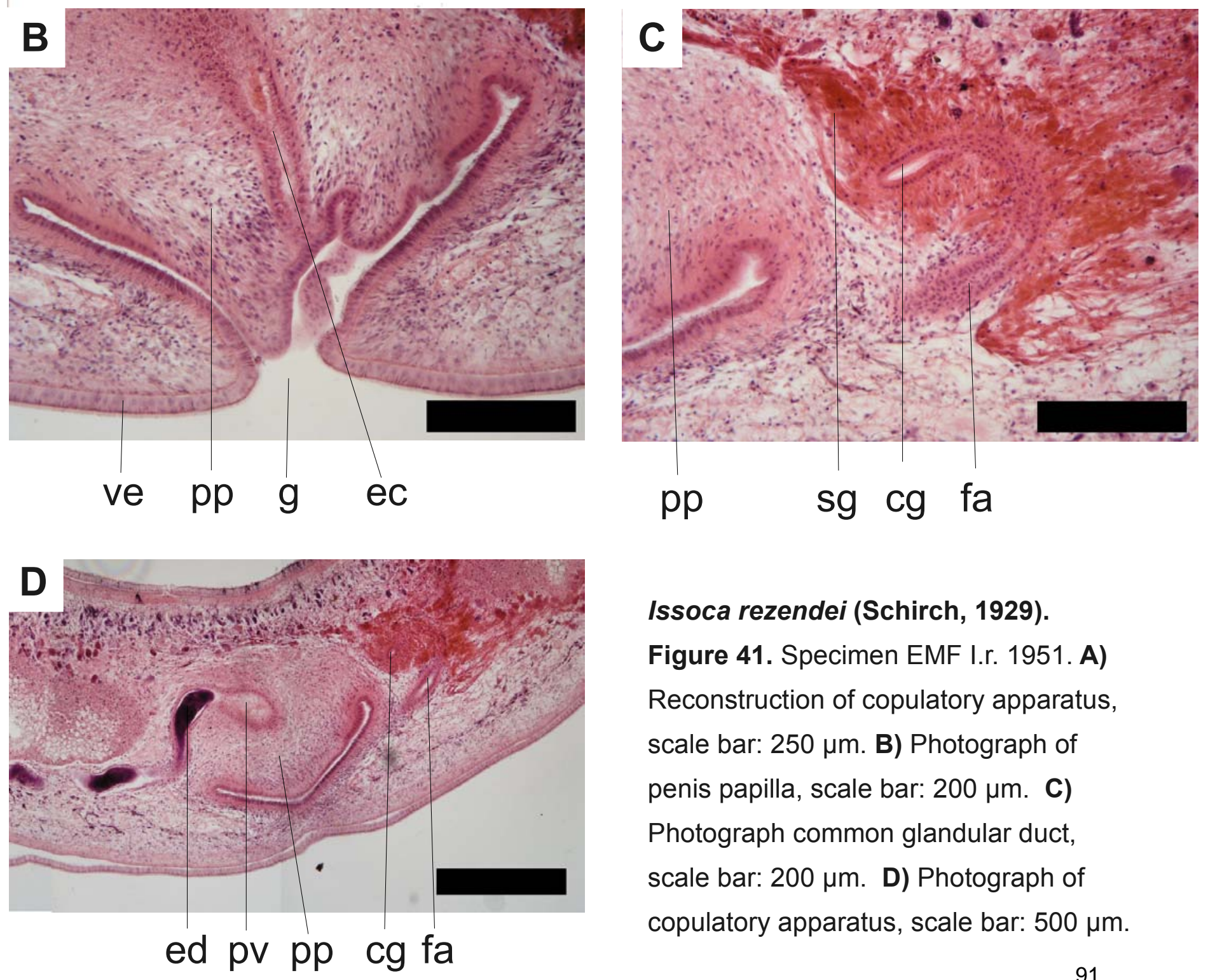

Issoca rezendei (Schirch, 1929).

Figure 41. Specimen EMF I.r. 1951. A)

Reconstruction of copulatory apparatus, scale bar: $250 \mu \mathrm{m}$. B) Photograph of penis papilla, scale bar: $200 \mu \mathrm{m}$. C) Photograph common glandular duct, scale bar: $200 \mu \mathrm{m}$. D) Photograph of copulatory apparatus, scale bar: $500 \mu \mathrm{m}$. 


\section{Liana guasa E. M. Froehlich, 1978}

\section{EXAMINED MATERIAL}

Holotype. Sagittal sections of the pharynx and copulatory apparathus on 7 slides. Sagittal sectiond of the anterior end on 8 slides. Paratype. Sagittal sections of the pharynx and the copulatory apparathus on 12 slides. Transversal sections on 17 slides.

\section{MORPHOLOGY}

External morphology. Sub-cylindrical body. Eyes extending round the anterior tip uniserially, posteriorly the multiply into two irregular series. Along the body the eyes are lateroventral in position. Small sensory pits of simple invaginations restricted to anterior end.

Sub-epidermic musculature. Tripartite cutaneous musculature. Ventral longitudinal layer divided into two portions; portion A placed directly above cutaneous double diagonal with fibers gathered in small bundles gathering a few fibers, and a second portion located above the subcutaneous nervous plexus. The second portion is totally insunk and reaches up to the central nervous system, forming one dense flat bundle. Second portion crossed by by decussate diagonal fibers in the most sagittal portions. Dorsal muscular also compacted in bundles and insunk into mesenchym. Ventral musculature (300 350 um) thinner than dorsal(110 - 140um).

Sub-epidermal secretions. Cyanophyll and erythrophyll glands opening through dorsal and ventral surface. Rhabdite forming cells abundant dorsally.

Mesenchymal musculature. At least three mesenchymal muscle layers. Transversal sub and supra intestinal, and decussate double diagonal. Longitudinal musculature not observed. Sub-neural ventral plate absent.

Digestive system. Pharynx occupying entire pharyngeal pocket (Figure 42A). Mouth located at the posterior half of pharyngeal pocket. Square shaped cylindrical pharynx with parallel insertions (Figure 42B). Esophagus very short, almost absent. Pharyngeal pocket musculature composed mainly of circular fibers. Tip of pharynx thinner and weaker in musculature, with erythrophyll accumulations. External pharynx musculature (Figure 42D) composed of sub-epithelial longitudinal layer followed by circular layer, followed by an internal layer of intermixed longitudinal and circular muscle fibers. External pharynx musculature about 100 um at thickest point. Internal pharynx musculature (Figure 42C) composed of strong intermixed layer of circular musculature with longitudinal fibers, with fibers gathered in 
small bundles or a few fibers thick. Internal pharynx musculature 150-170 um at thickest point.

Central nervous system. Organized as a ventral plate.

Male reproductive organs. Testes immature, placed dorsally internal to supraintestinal mesenchymal layer. Extending until root of pharynx. Elongated prostatic vesicle. Conical shaped penis papilla o penial fold. Copulatory organs still in development. 
A
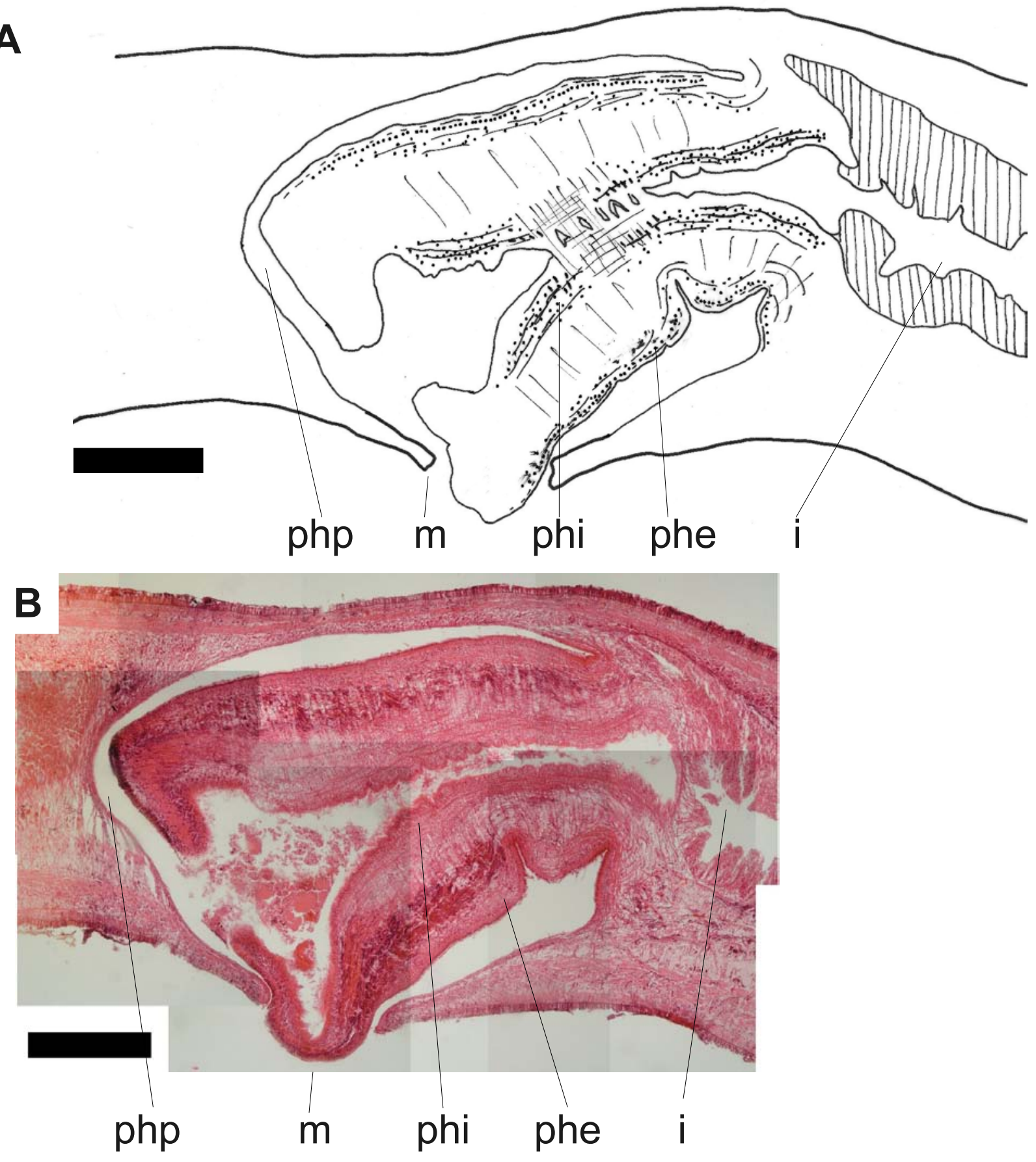

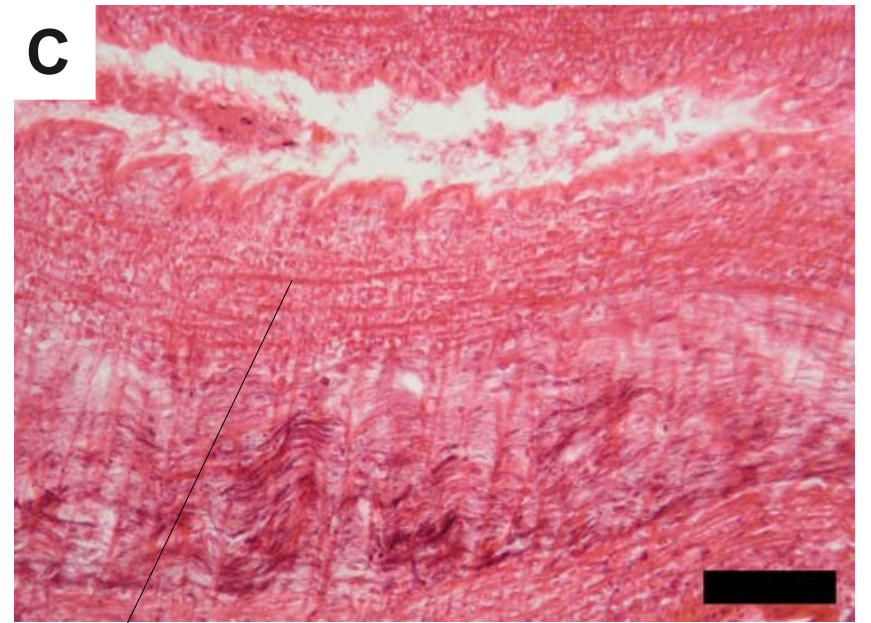

phi

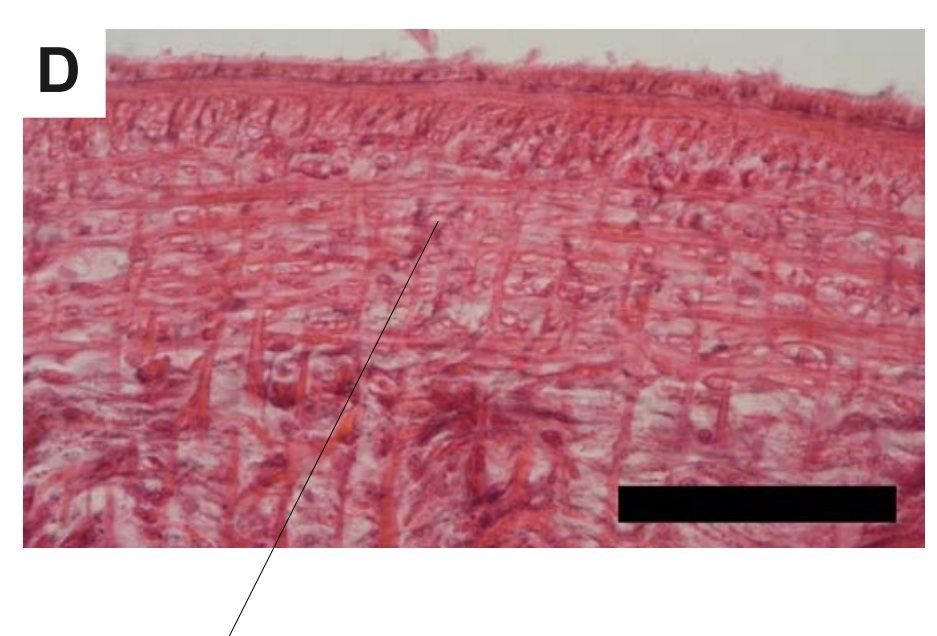

phe

Liana guasa E. M. Froehlich, 1978. Figure 42. Paratype. A) Reconstruction of pharynx, scale bar: $500 \mu \mathrm{m}$. B) Photograph of pharynx, scale bar: $500 \mu \mathrm{m}$. C) Photograph of internal pharynx musculature, scale bar: $50 \mu \mathrm{m}$. D) Photograph external pharynx musculature, scale bar: $50 \mu \mathrm{m}$. 


\section{Notogynaphallia plumbea (C. G. Froehlich, 1956)}

\section{SYNONYM}

Geoplana plumbea C. G. Froehlich, 1956.

\section{EXAMINED MATERIAL}

IPP 1292: Anterior region 1, transversal sections on 11 slides; Anterior region 2, sagittal sections on 10 slides; pharynx, sagittal sections in 10 slides; copulatory apparatus, sagittal section on 11 slides.

\section{MORPHOLOGY}

External morphology. Sub-cylindric body (Figure 44B). Creeping sole wide. Eyes monolobated, around 35um in diameter. Distributed laterally extending through the whole body. Surrounding anterior tip in a single row. Sensory pits composed of simple invagination about 20um deep. Sensory pits surrounding the anterior tip.

Sub-epidermic musculature. Tripartite musculature. In the cephalic region the layers are extinguished without rearrangements (Figure 43A). Sub-epidermic musculature packed in bundles (Figure 44D).

Sub-epidermal secretions. Glandular ridge and glandular keel absent. Glandular accumulation in cephalic region (Figure 43B).

Mesenchymal musculature. Three typical mesenchymal layers. In the cephalic region the layers are extinguished without rearrangements. Mesenchymatical longitudinal musculature absent (Figure $44 \mathrm{~A}$ ).

Digestive system. Mouth located posterior third of the pharyngeal pocket (Figure 45A). Cylindrical pharynx, dorsal insertion slightly posterior to ventral. Pharynx occupying almost $80 \%$ of the pharyngeal pocket (Figure 45B). Pharyngeal pocket composed of simple circular fibers. External pharynx musculature (Figure 45D) composed of sub-epithelial longitudinal layer followed by a circular layer. Internal pharynx musculature (Figure 45C) composed of a thick circular layer with intermixed longitudinal fibers.

Central nervous system. Flat plate type.

Male reproductive organs. Testes Globulouse to elongated in shape. Placed dorsally underneath to the transversal supra-intestinal mesenchymal muscle layer (Figure 44C). Testes pre-pharyngeal, extending from the ovaries region to the root of the pharynx. Efferent ducts bend in a dorso anterior angle just after entering the common muscular coat. Prostatic 
vesicle globular in shape and opens directly into the male atrium. Penis papilla absent (Figure 46A). Male atrium folded (Figure 46B). Efferent ducts with cubic ciliated epithelium. Efferent duct musculature composed of circular musculature. Ejaculatory duct absent (Figure 46D). Prostatic vesicle with columnar ciliated epithelium. Prostatic vesicle musculature composed of diagonal and circular fibers. Male atrium with ciliated epithelium. Male atrium musculature composed of longitudinal and circular fibers.

Female reproductive organs. Elongated shaped ovaries, placed underneath the mesenchymal sub-intestinal layer. Ovovitelline ducts arising from medial dorsal surface, and extending backwards at the same level. The ovovitelline ducts rise after the gonopore to fuse into a short common glandular channel about five times its diameter. The vagina is orientated horizontally and open to the posterior most part of the female atrium (Figure 46C). The vagina is located at a mid lower level of the female atrium. The female atrium is a thin slightly folded irregular channel. Female atrium with columnar epithelium with basophyll and xanthophyll glands. Female atrium musculature composed of longitudinal and circular fiber. Ovovitelline ducts with cubic ciliated epithelium. Shell glands in the last portion before forming common glandular duct. Common muscular coat composed diagonal and circular fibers wrapping the distal portion of the efferent ducts, prostatic vesicle, male and female atrium and the part of the vagina. 
A
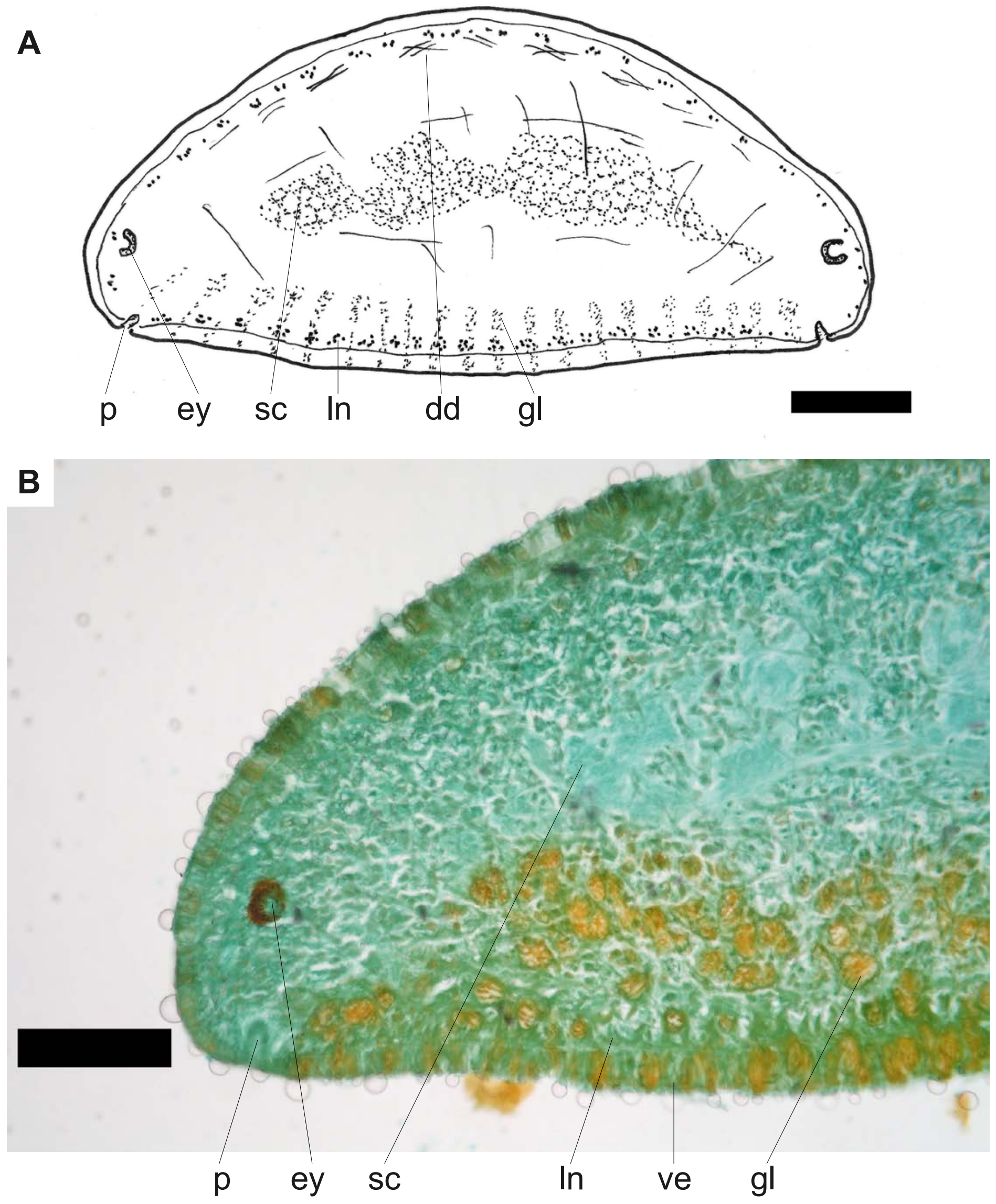

Notogynaphallia plumbea (C. G. Froehlich, 1956). Figure 43. Specimen IPP 1292. A)

Reconstruction of section of anterior region, scale bar: $200 \mu \mathrm{m}$. B) Photograph of section of anterior region, scale bar: $200 \mu \mathrm{m}$. 
A
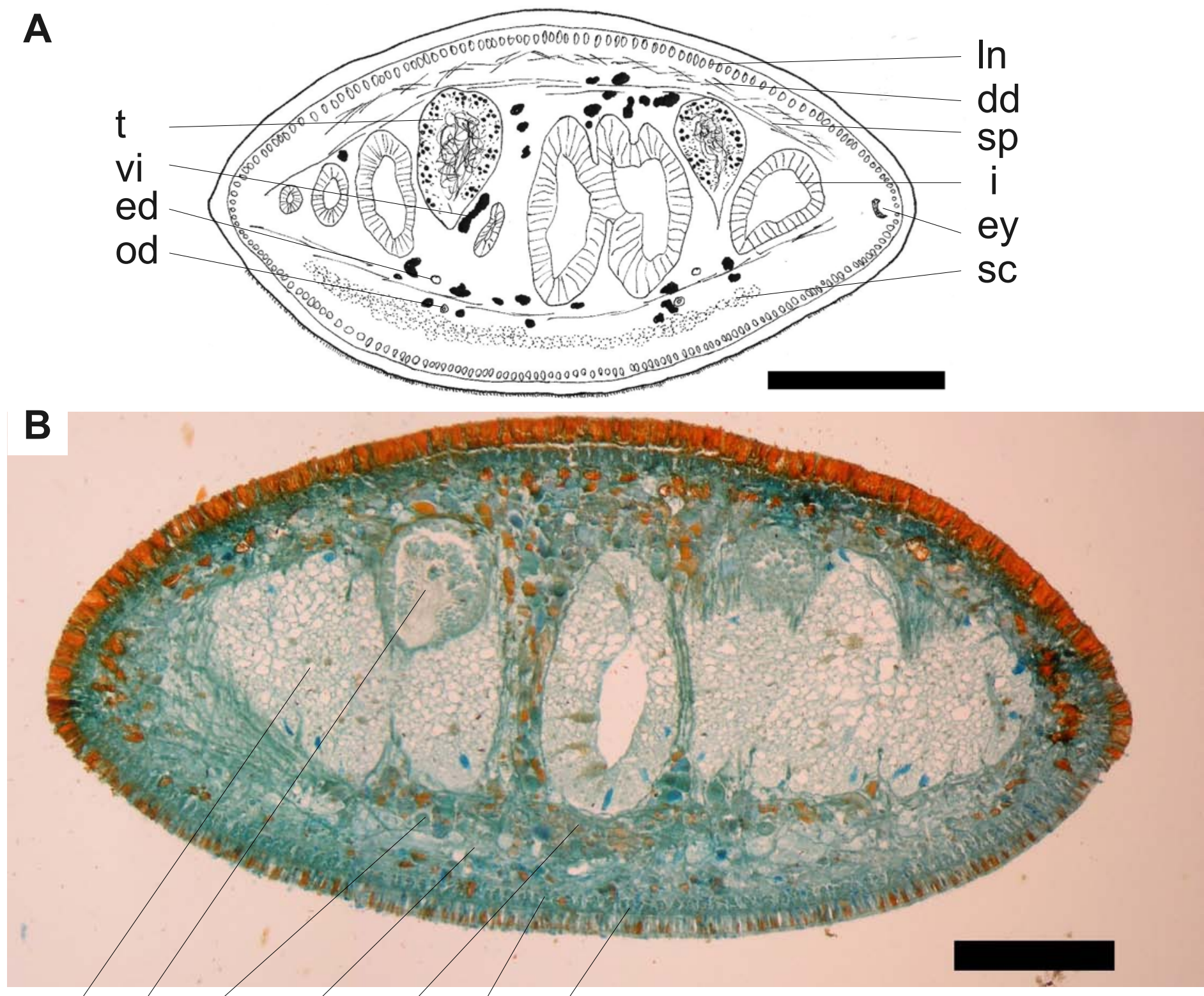

i $t$ od sc sb In ve

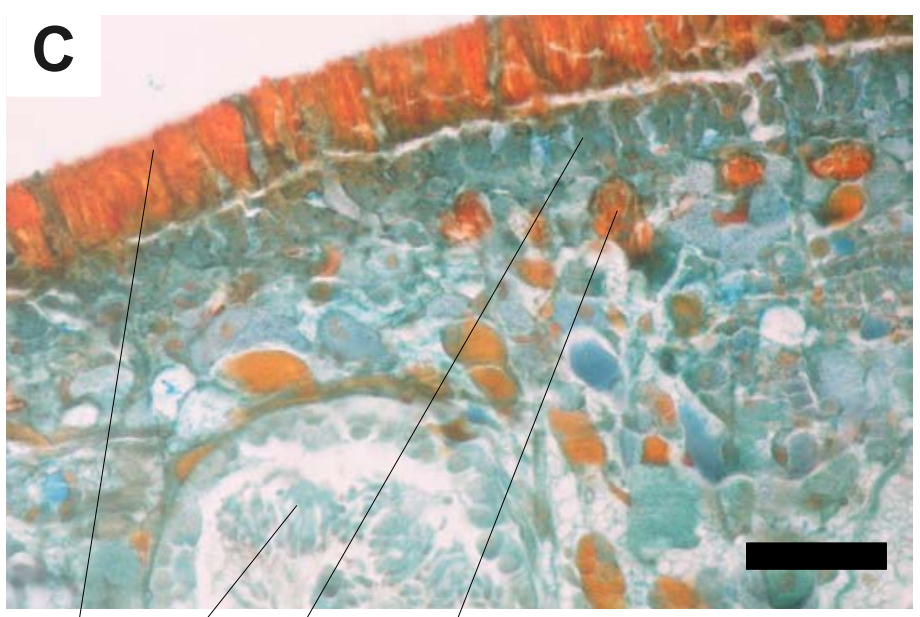

de $\mathrm{t}$ In $\mathrm{rb}$

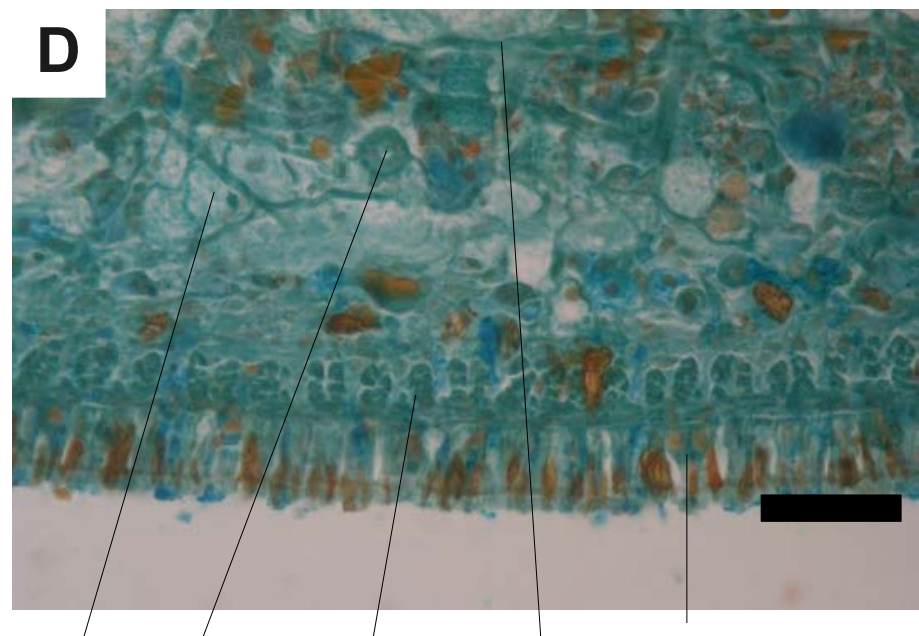

sc od In sb ve

Notogynaphallia plumbea (C. G, Froehlich, 1956). Figure 44. Specimen IPP 1292. A)

Reconstruction of section of pre-pharyngeal region, scale bar: $250 \mu \mathrm{m}$. B) Photograph of section of pre-pharyngeal region, scale bar: $200 \mu \mathrm{m}$. C) Photograph of dorsal sub-epidermic musculature, scale bar: $50 \mu \mathrm{m}$. D) Photograph ventral sub-epidermic musculature, scale bar: $50 \mu \mathrm{m}$. 
A
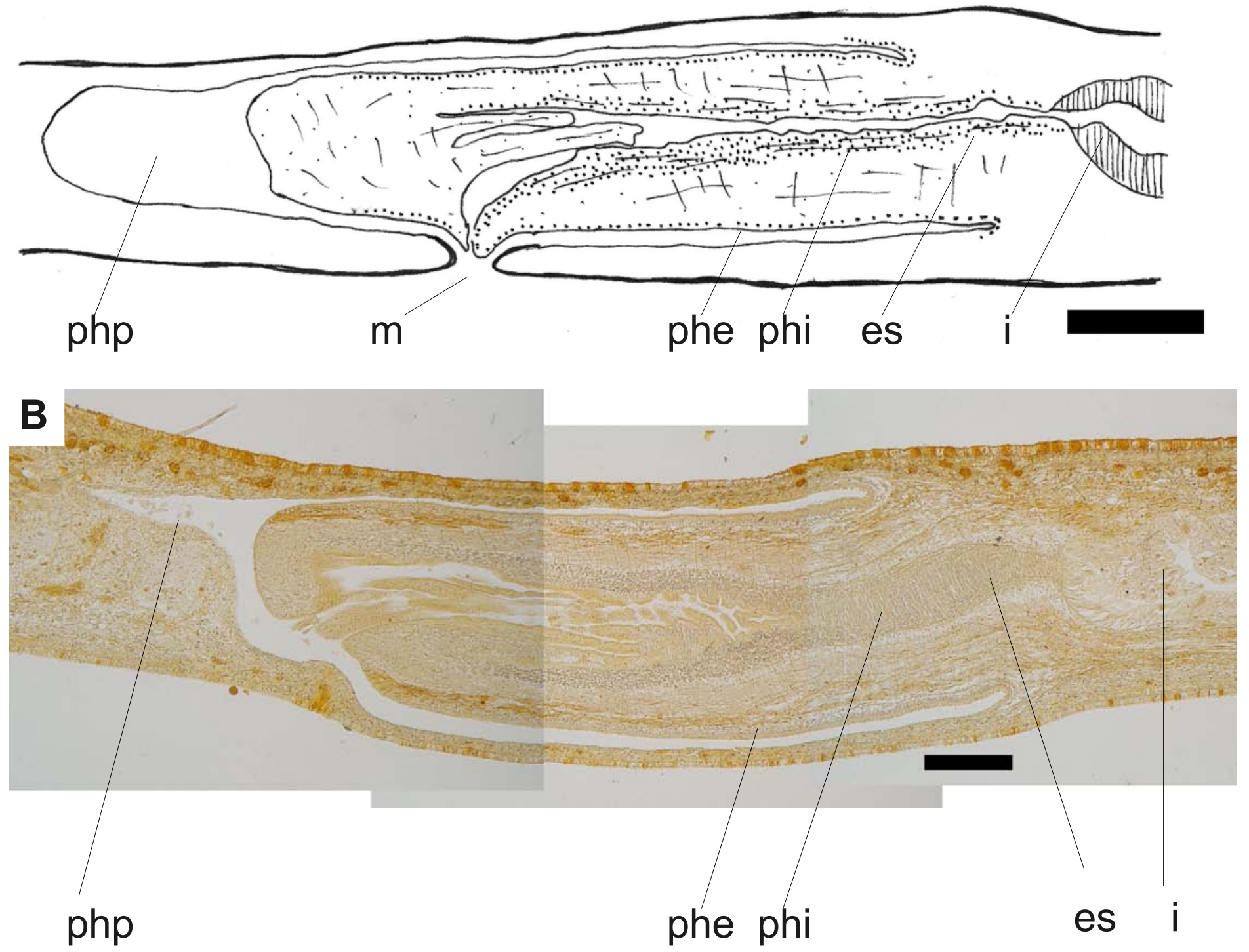

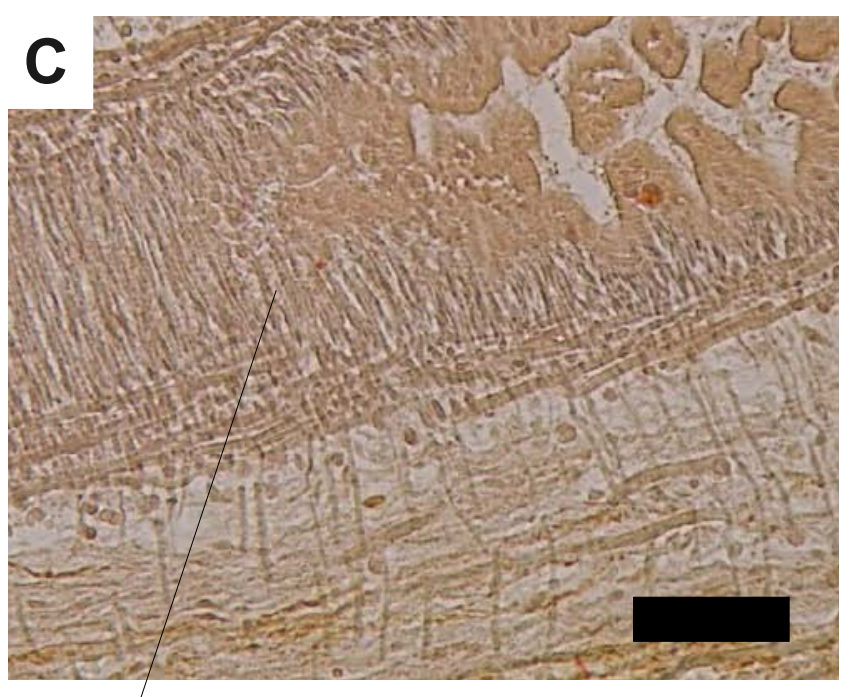

phi

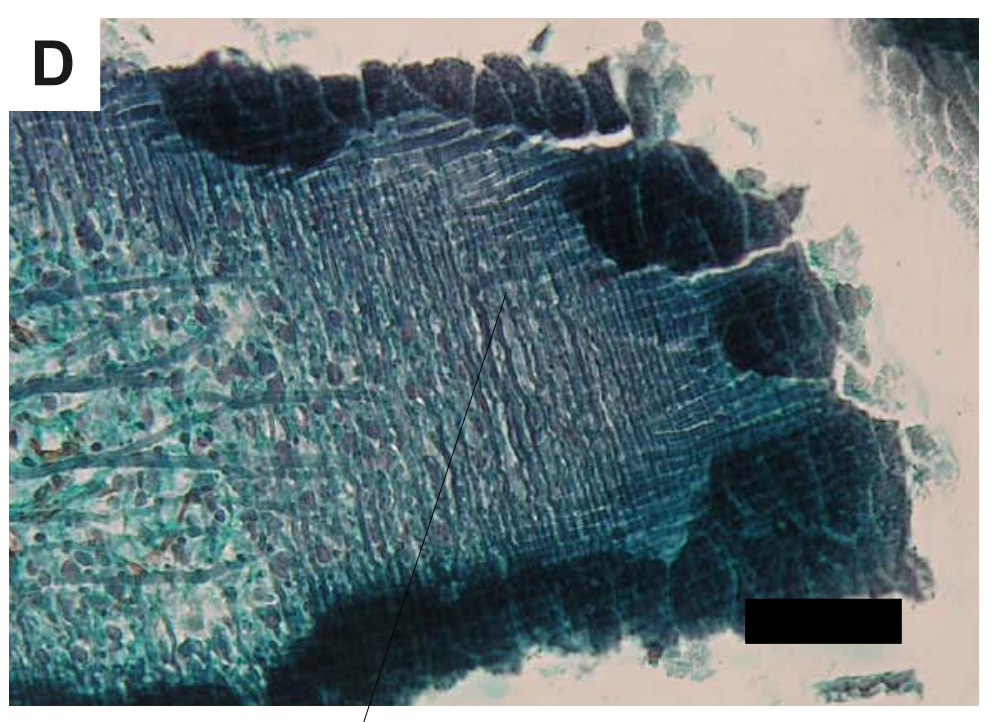

phe

Notogynaphallia plumbea (C. G. Froehlich, 1956). Figure 45. Specimen IPP 1292. A)

Reconstruction of section of pre-pharyngeal region, scale bar: $500 \mu \mathrm{m}$. B) Photograph of section of pre-pharyngeal, scale bar: $200 \mu \mathrm{m}$. C) Photograph of internal pharynx musculature, scale bar: $50 \mu \mathrm{m}$. D) Photograph external pharynx musculature, scale bar: $50 \mu \mathrm{m}$. 

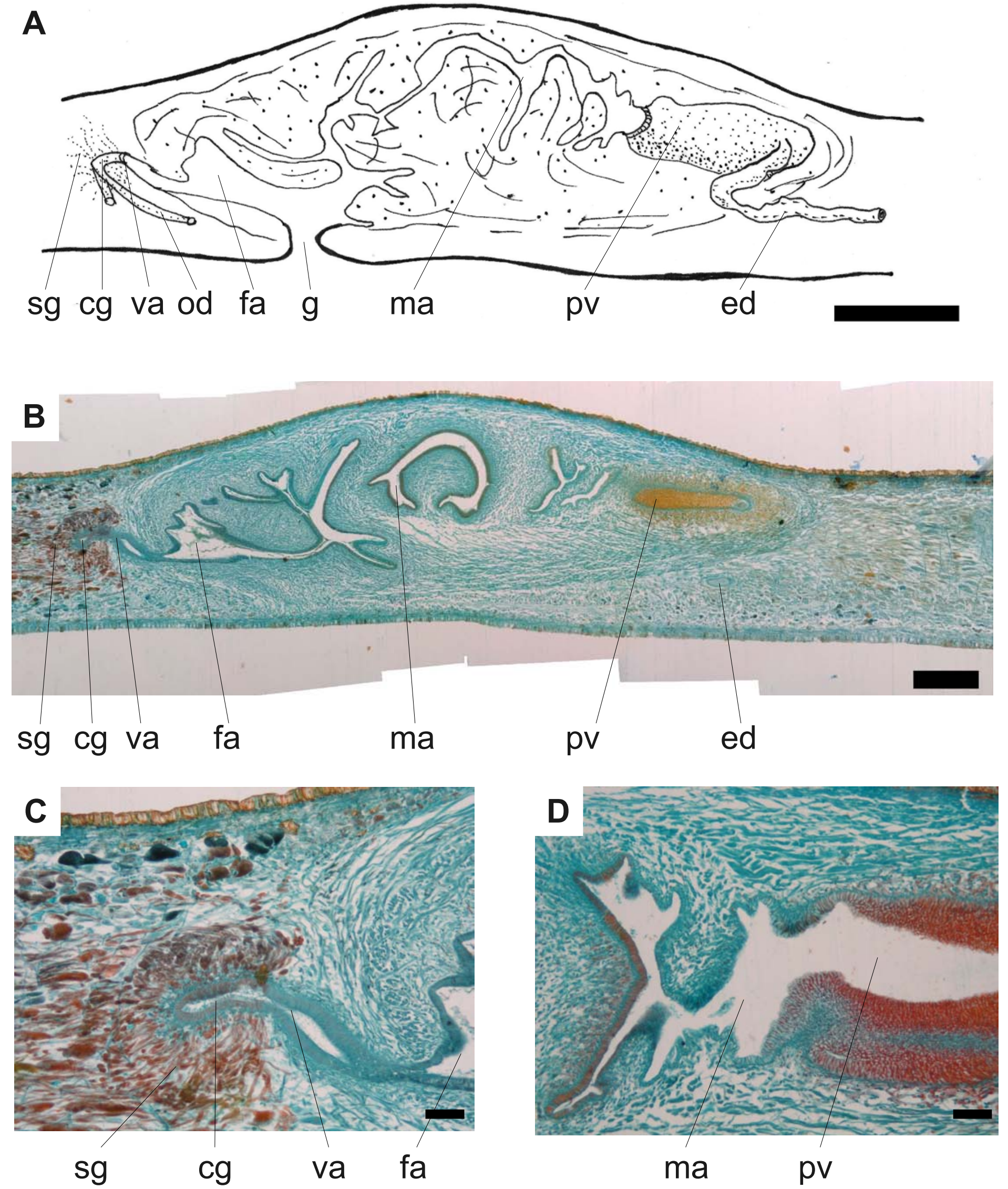

Notogynaphallia plumbea (C. G. Froehlich, 1956). Figure 46. Specimen IPP 1292. A)

Reconstruction of copulatory apparatus, scale bar: $500 \mu \mathrm{m}$. B) Photograph of copulatory apparatus, scale bar: $200 \mu \mathrm{m}$. C) Photograph of vagina, scale bar: $50 \mu \mathrm{m}$. D) Photograph prostatic vesicle, scale bar: $50 \mu \mathrm{m}$. 


\section{Pasipha pasipha (Marcus, 1951)}

\section{SYNONYM}

Geoplana pasipha n. sp. Marcus, 1951.

\section{EXAMINED MATERIAL}

FCB 592: Sagittal sections of copulatory apparatus and pharynx on 13 slides. EMF ophelis PA130287(2): Transversal sections of pre-pharyngeal region on 12 slides. EMF ophelis PA040776: Transversal sections of anteriorl region on 32 slides.

\section{MORPHOLOGY}

External morphology. Flat body (Figure 48A). Creeping sole wide. Eyes present in anterior tip in a single row, extending backwards in multiple rows. Sensory pits consist of simple invaginations, present in anterior tip, extending in anterior third (Figure 47A).

Sub-epidermal musculature. Tripartite sub-epidermal musculature. Longitudinal musculature packed in bundles (Figure 48C). Sub-epidermal musculature stronger ventrally than dorsally. In the cephalic region the sub-epidermic musculature gradually extinguishes without modifications(Figure 47C, 47D).

Sub-epidermal secretions. Glandular ridge absent (Figure 48B). Cephalic region without glandular accumulations.

Mesenchymal musculature. Mesenchymal musculature composed of three main layers: a dorsal diagonal layer with decussate fibers, a supra-intestinal layer also with transversal-decussate arrangement, and a sub-intestinal transversal layer. Longitudinal mesenchymal musculature absent. Same mesenchymatic muscle arrangement in the prepharynx region and the cephalic region (Figure 47B).

Digestive system. Mouth located at posterior third of pharyngeal pocket (Figure 49B). Pharynx occupying $80 \%$ of pharyngeal cavity. Small diverticle at the posterior end of pharyngeal pocket. Pharynx shape cylindrical. Dorsal insertion posterior to ventral insertion. Esophagus present as small muscular funnel (Figure 49A). Pharyngeal pocket with flat non ciliated epithelium. Pharyngeal pocket musculature with circular and longitudinal fibers. External pharynx with cuboidal ciliated epithelium. External pharynx musculature (Figure 49D) composed of a thin longitudinal followed by a thin circular. Underneath these there is a third layer of intermixed longitudinal and circular fibers. Internal pharynx with cuboidal ciliated 
epithelium . Internal pharynx musculature (Figure 49C) composed of thick sub-epithelial circular layer followed by a thin longitudinal layer. Internal pharynx muscles not intermixed.

Central nervous system. Flat plate type

Male reproductive organs. Testes rounded, extending from anterior region to the root of pharynx. Placed dorsally underneath transversal supra-intestinal mesenchymal layer (Figure 48D). Each efferent duct extending posteriorly, beyond prostatic vesicle and then bending in an antero dorsal angle to open into the prostatic vesicle. Prostatic vesicle dived in two functional vesicles (Figure 50B). Vesicle $A$ is located dorsally and directly beside the pharyngeal pocket, it is rounded shape receive the sperm from the efferent ducts. Vesicle $B$ is a tubular shaped vesicle, located ventrally, extending underneath the common muscular coat and slightly beyond the male atrium. Vesicle $A$ connects with vesicle $B$ through a sinuous passage about half the caliber of vesicle $A$. Vesicle $B$ opens through an ejaculatory duct directed in an antero-posterior angle directly to male atrium. Apapillate male atrium folded (Figure 50A). Efferent ducts with flat non ciliated epithelium. Anterior region of the prostatic vesicle with external wrapping of sparse reticulate musculature and an inner sub-epithelial more dense wrapping of circular fibers. Epithelium composed of pseudostratified columnar ciliated epithelium. Posterior portion of the prostatic vesicle densely wrapped in circular musculature. Opening of dense granulouse erytrophyll secretion opening through posterior portion of the vesicle. Ejaculatory ducts opens ventrally to male atrium (Figure 50D). Male atrium with cubical ciliated epithelium. Male atrium composed of intermixed longitudinal and circular fibers. Male atrium with a dense cyanophyll secretory fold in anterior most part. Halfway to gonopore with apical granulouse erytrophyll secretions.

Female reproductive organs. Oviducts approaching copulatory apparatus ventrally and forming a vertical common glandular duct. Shell glands opening through the last portion of the oviducts and the common glandular duct. Vagina elongated, directed ventrally in a vertical anteriorly angle connecting with common glandular duct (Figure 50C). Vaginal musculature composed of circular musculature. Female atrium largely folded, with pseudostratified epithelium apically with granulouse erytrophyll secretion. Common muscular coat wrapping male and female atrium, and the vagina. 
A
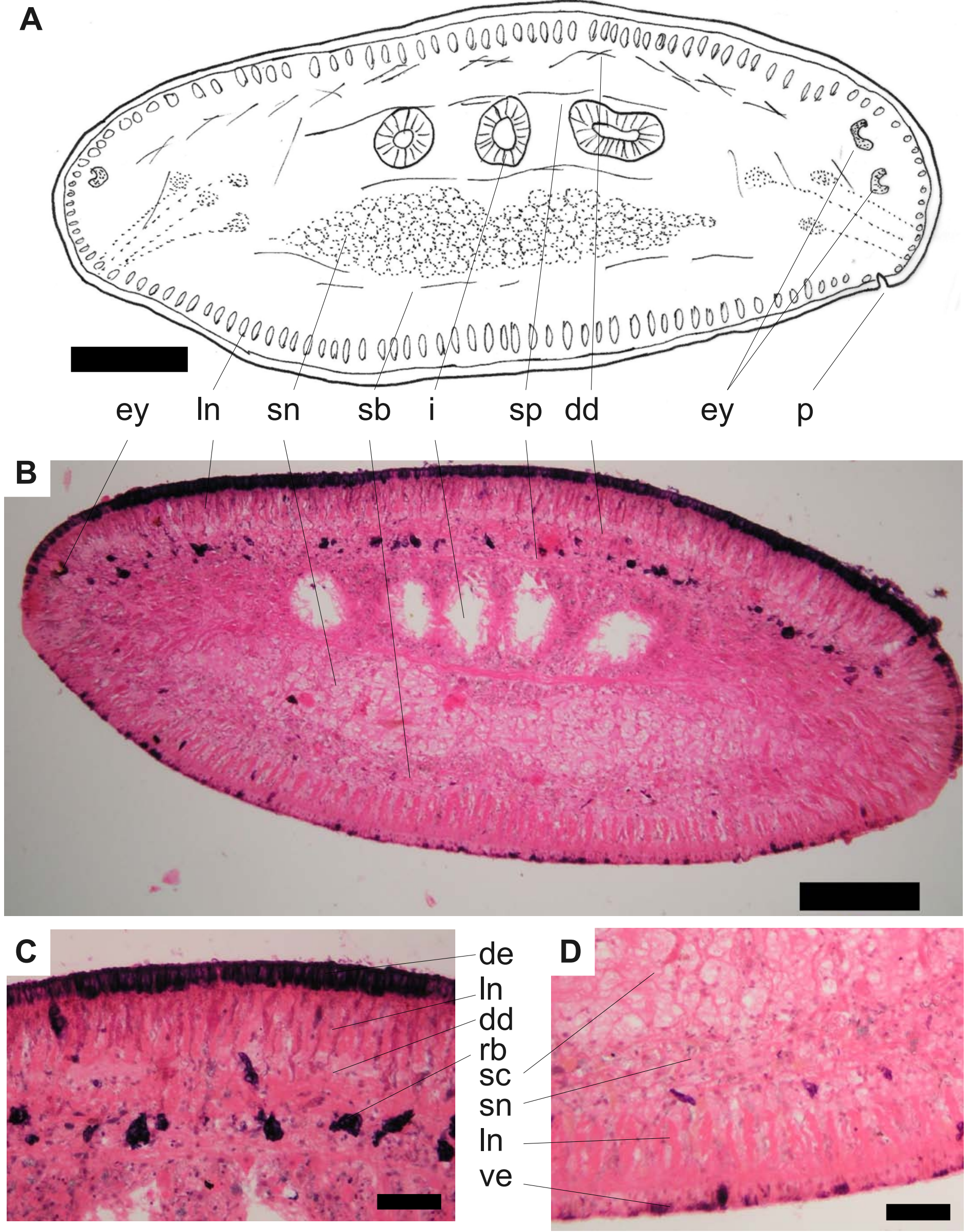

Pasipha pasipha (Marcus, 1951). Figure 47. Specimen EMF Ophelis PA040776. A)

Reconstruction of anterior region, scale bar: $200 \mu \mathrm{m}$. B) Photograph of transversal section of anterior part, scale bar: $200 \mu \mathrm{m}$. C) Photograph of dorsal cutaneous musculature, scale bar: 50 $\mu \mathrm{m}$. D) Photograph of ventral cutaneous musculature, scale bar: $50 \mu \mathrm{m}$. 
A
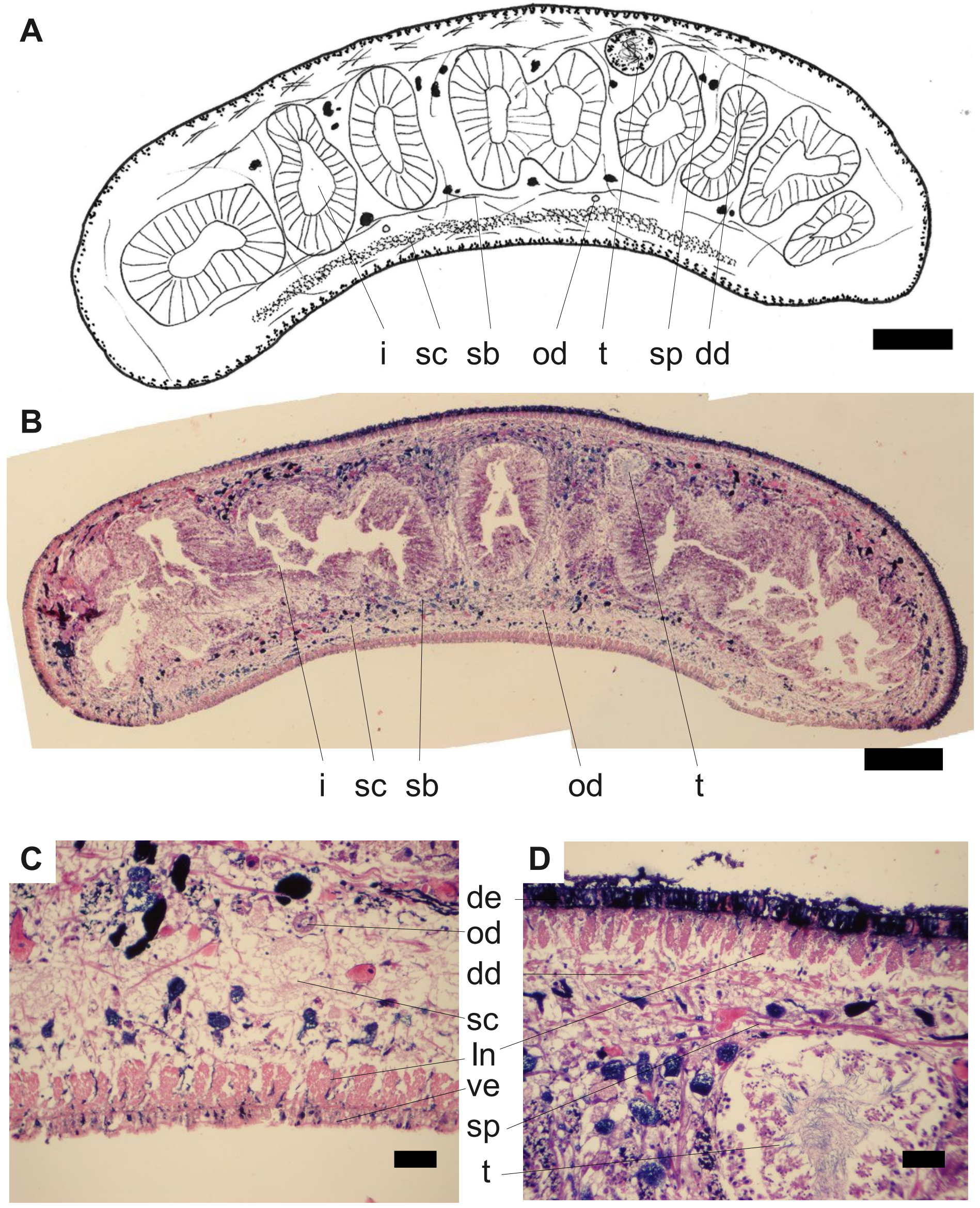

Pasipha pasipha (Marcus, 1951). Figure 48. EMF Ophelis PA130287(2). A) Reconstruction of transversal section pre-pharynx, scale bar: $500 \mu \mathrm{m}$. B) Photograph of transversal section of prepharynx, scale bar: $500 \mu \mathrm{m}$. C) Photograph of ventral cutaneous musculature, scale bar: $50 \mu \mathrm{m}$. D) Photograph of dorsal cutaneous musculature, scale bar: $50 \mu \mathrm{m}$. 
A
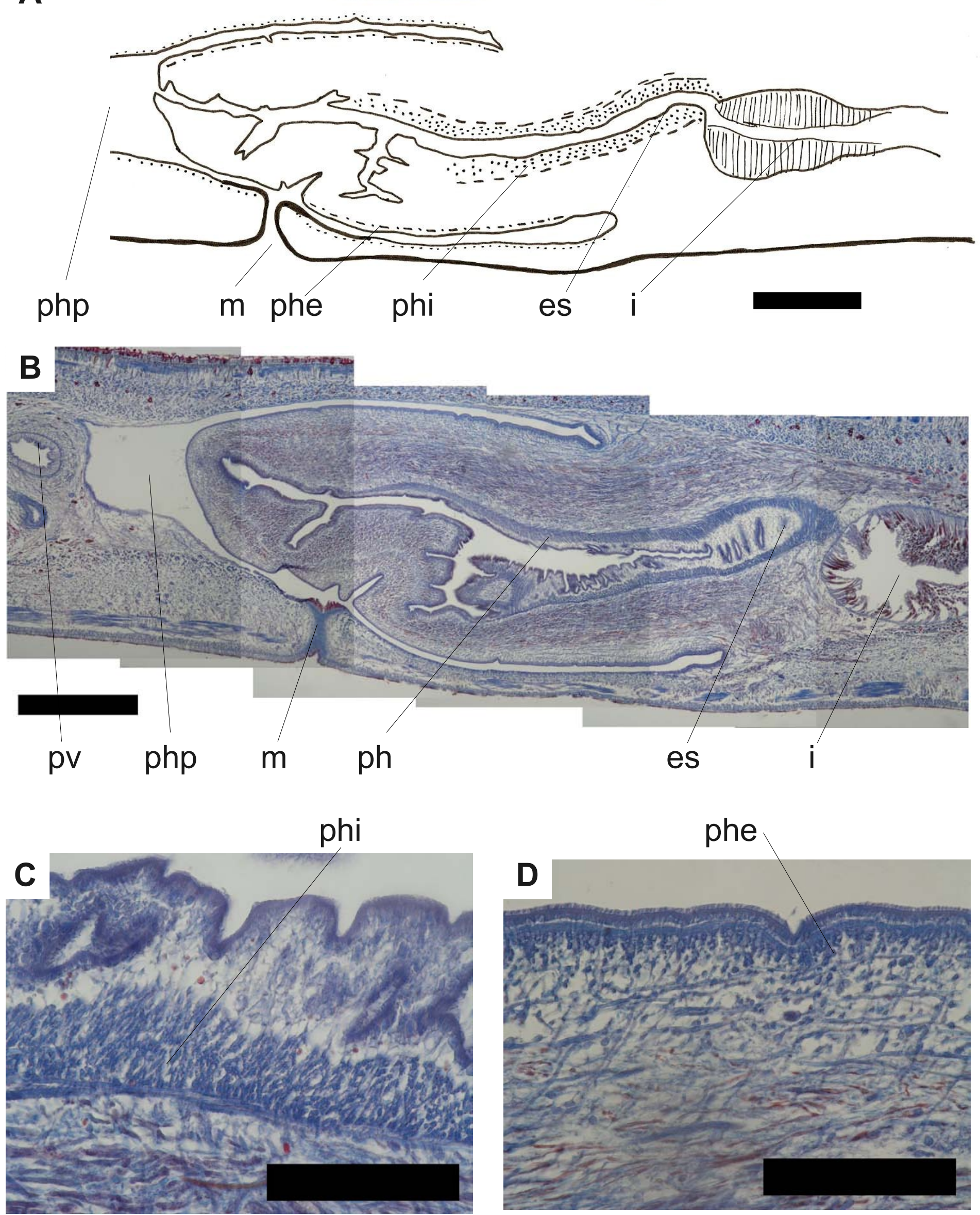

phe

Pasipha pasipha (Marcus, 1951). Figure 49. Specimen FCB 529. A) Reconstruction of pharynx, scale bar: $500 \mu \mathrm{m}$. B) Photograph of pharynx, scale bar: $500 \mu \mathrm{m}$. C) Photograph of internal pharynx musculature, scale bar: $200 \mu \mathrm{m}$. D) Photograph of external pharynx musculature, scale bar: $200 \mu \mathrm{m}$. 
A
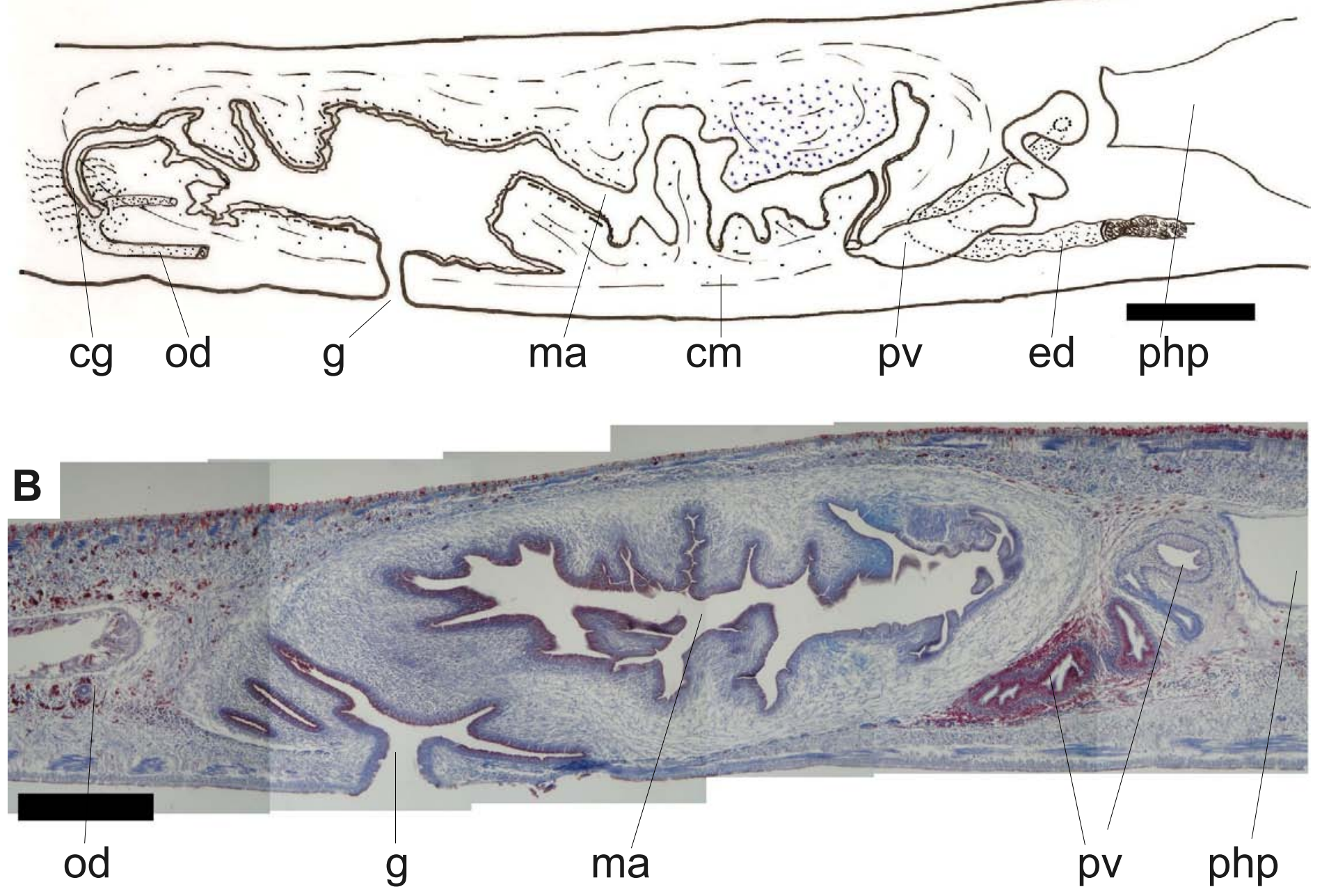

Pasipha pasipha (Marcus, 1951). Figure 50.

Specimen FCB 592. A) Reconstruction of

C

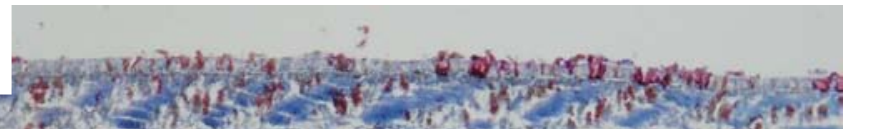
copulatory apparatus, scale bar: $500 \mu \mathrm{m}$. B)

Photograph of of copulatory apparatus, scale bar: $500 \mu \mathrm{m}$. C) Photograph of female canals, scale bar: $250 \mu \mathrm{m}$. D) Photograph of prostatic vesicle, scale bar: $250 \mu \mathrm{m}$.

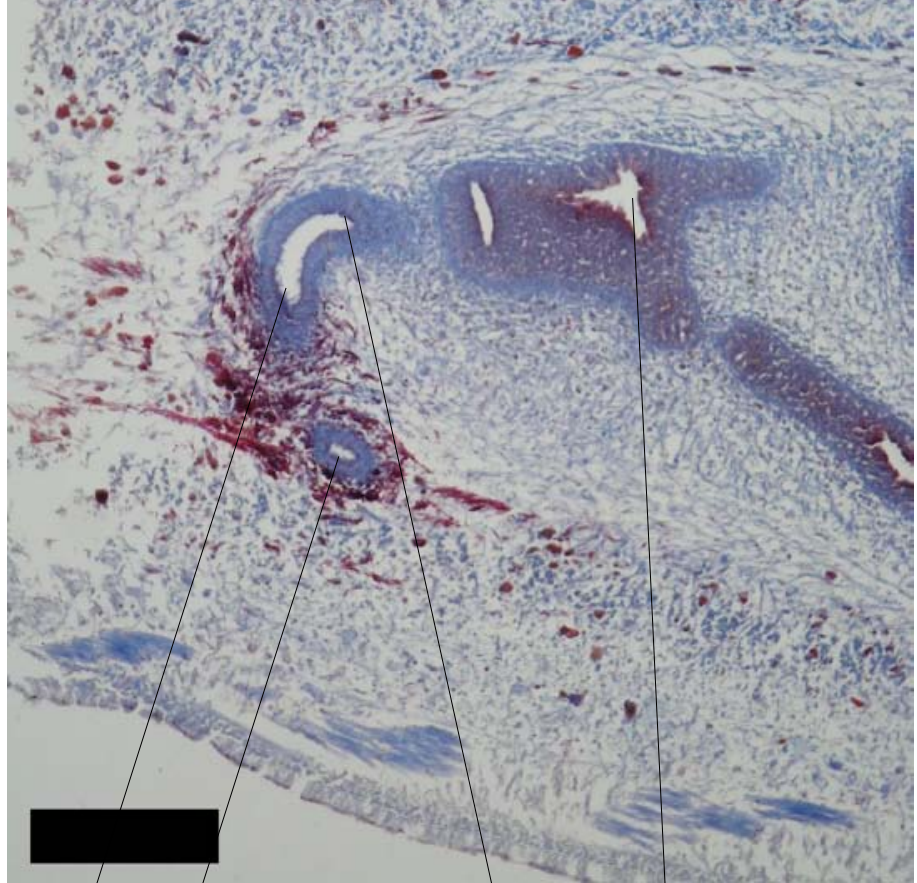

cg ov

va fa

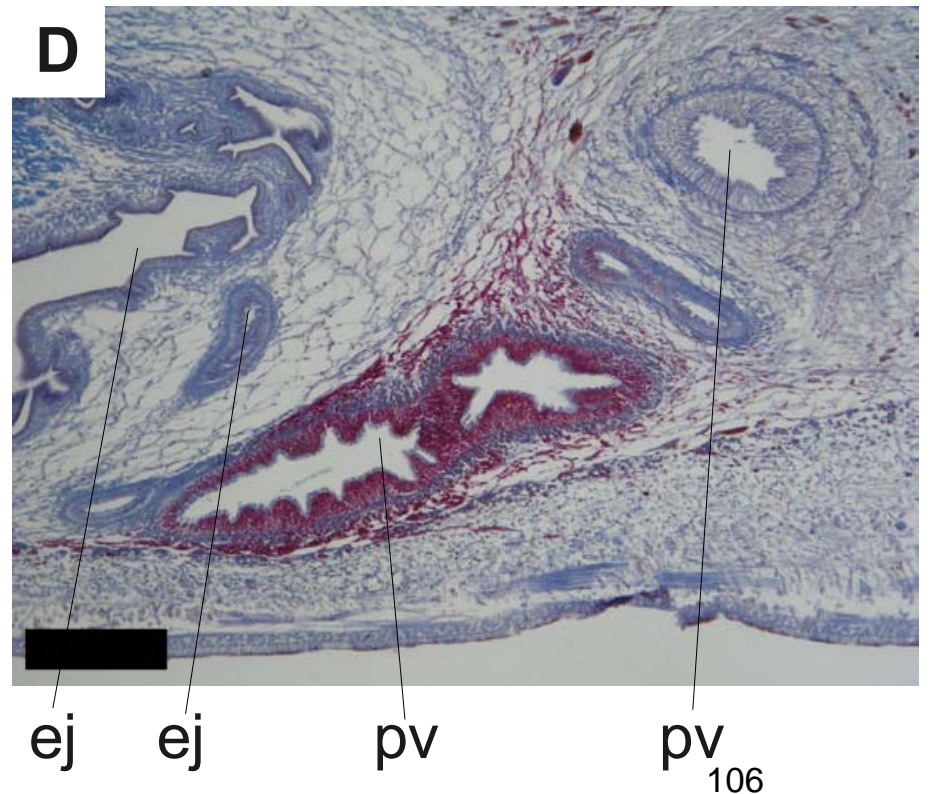




\section{Pelmatoplana moluccana von Graff, 1899}

\section{EXAMINED MATERIAL}

NHM 2767: Holotype. Transversal sections of anterior part, horizontal sections of anterior part 2, transversal sections of pre-pharynx and sagittal sections of pharynx and copulatory apparatus in 20 slides.

\section{MORPHOLOGY}

External morphology. Body shape cylindrical (Figure 51A). Creeping sole thin, representing $20 \%$ of body width. Eyes present in a single row in the anterior tip; after some $2 \mathrm{~mm}$ up to two eyes per side have been observed in single transversal section. In transverse section most eyes appear on the lower half of the body. Eye cup monolobulated and multicellular measuring $30 \times 35 \mu \mathrm{m}$ in diameter. Sensory pits unconscious. Sensory fends absent.

Sub-epidermal musculature. Sub-epidermal musculature composed of single fibers, not packed in bundles. Outermost sub-epidermal musculature very weak, made up of unique separate fibers; composed of circular fibers, but rapidly intermingling and resembling diagonal disposition.

Sub-epidermal secretions. Glandular keel present, with granular erytrophyll secretions opening through creeping sole. Glandular ridge absent. Mainly rhabdite cells opening through body wall. Ventral epithelium tall and nucleated.

Mesenchymal musculature. Mesenchymal musculature organized in thick fibers that are arranged in a strong longitudinal muscular tube that encloses the nervous, digestive and reproductive systems (Figure 51C). Longitudinal fiber may also be found in between the nerve chords. The supra and sub-intestinal intermixed with the muscular tube. Sub-neural transversal fibers maybe found in underneath the nerve chords. A large bundle of longitudinal fibers $(190 \times 130 \mu \mathrm{m})$ goes through the brain, resembling a cephalic retractor muscle (Figure 51B).

Digestive system. Short cylindrical pharynx (Figure 52A). Directed ventro-posterior angle. Pharynx occupying the whole pharyngeal cavity (Figure 52D). Mouth located at the posterior end of pharyngeal cavity. Esophagus absent (Figure 52B). Pharyngeal cavity composed of circular and longitudinal musculature. External pharynx musculature (Figure 52C) composed of an external most longitudinal layer followed by a circular layer. External pharynx musculature not intermixed. Internal pharynx musculature composed of a main sub- 
epithelial circular layer $(15-25 \mu \mathrm{m})$ followed by a longitudinal layer $(5-15 \mu \mathrm{m})$. Circular layer inter crossed by some unique longitudinal fibers.

Central nervous system. Brain located anteriorly, some $150 \mu \mathrm{m}$ behind anterior tip. Central nervous system composed of two chords.

Male reproductive system. Testes tall globular in shape. Embedded immediately above the sub-intestinal mesenchymal layer and lateral to the intestinal branches. Testes located posteriorly, extending from $800 \mu \mathrm{m}$ in front to the pharynx to posterior to the copulatory apparatus. Efferent dorsal to nerve chords and located between the ovovitelline ducts. Efferent ducts approach the copulatory apparatus separately and extend posteriorly up the insertion of the penial fold bend anterior-dorsally to open into the prostatic vesicle through a thin connection about $500 \mu \mathrm{m}$ long and $50 \mu \mathrm{m}$ in diameter. Efferent ducts lined with flat epithelium wrapped in circular musculature. No glands associated. The prostatic vesicle consists of an irregular globular cavity, about $550 \mu \mathrm{m}$ long by $260 \mu \mathrm{m}$ at its broadest point. The prostatic vesicle opens directly to the male atrium through a penial structure (Figure 53B). Prostatic vesicle musculature composed of fibers in all directions, but predominantly circular. Surrounded and penetrated by dense granular erytrophyll secretions. Epithelium composed tall columnar epithelium filled with secretions. Musculature of penis papilla composed of intermingled longitudinal and circular fibers. Male atrium wrapped in this but dense sub-epithelial circular musculature, followed by intermixed circular and longitudinal fibers.

Female reproductive system. Ovaries, globular in shape, measuring 130-140 $\mu \mathrm{m}$ in diameter; placed external and above the nerve chords, underneath the sub-intestinal muscle layer. The are placed half way from the anterior tip to the mouth. Ovovitelline connection to ovaries is uncertain. Ovovitelline approaching ventral, extending beyond gonopore and turning dorsally to fuse into a common glandular duct. The common glandular duct runs vertically upwards and gradually bends proximally and opens directly to female atrium. Female atrium consists of a thin communication from the male atrium to common glandular duct (Figure 53A). Opening anterior to gonopore from the dorsal side of a the male atrium. Ovovitelline lined with cubic ciliated epithelium. Composed of very thin or invisible muscle fibers. Shell glands opening through the last portion of the ovovitelline and the through common glandular duct. Common muscular coat inconspicuous. 
A
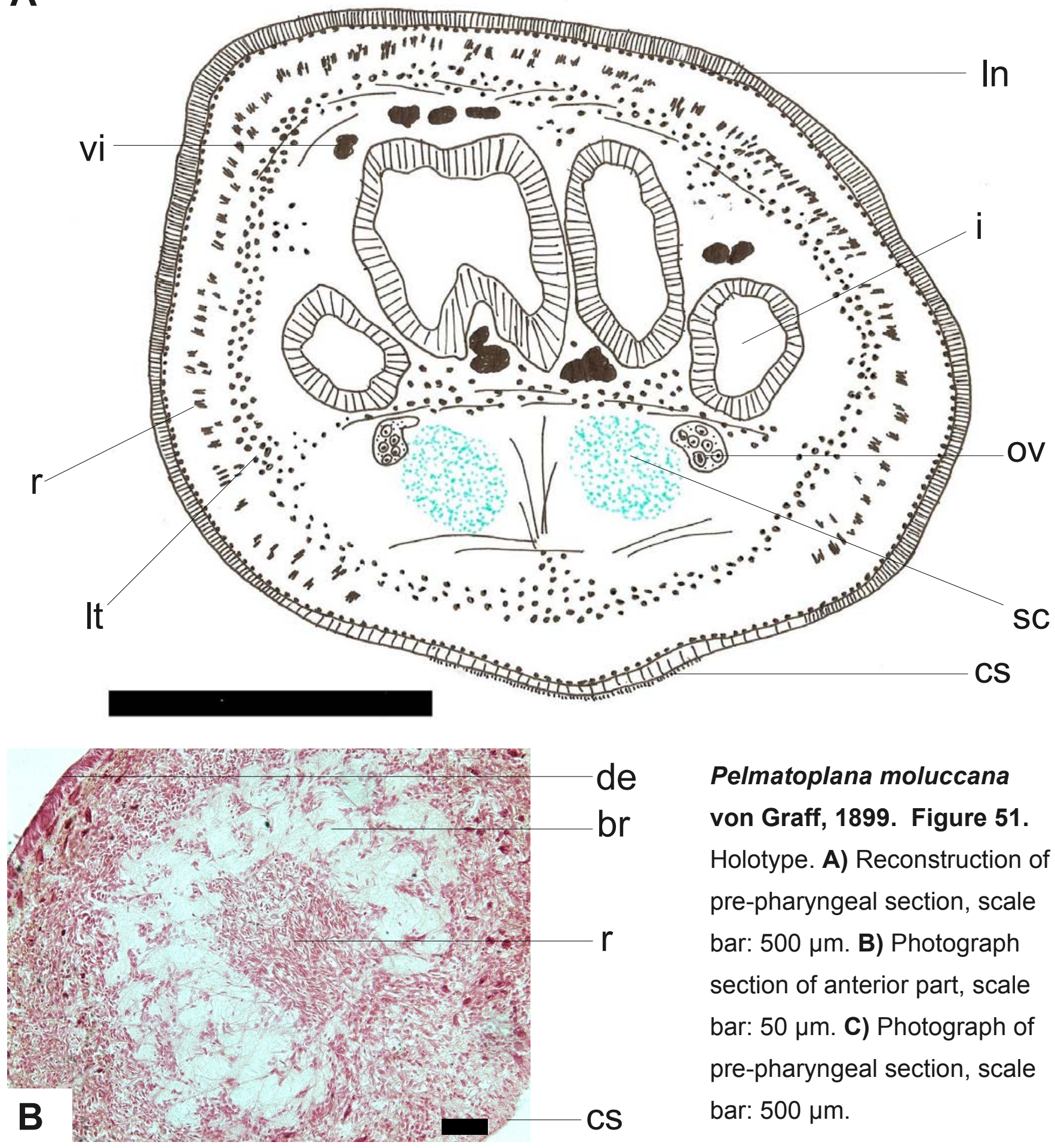

Pelmatoplana moluccana von Graff, 1899. Figure 51.

Holotype. A) Reconstruction of pre-pharyngeal section, scale bar: $500 \mu \mathrm{m}$. B) Photograph section of anterior part, scale bar: $50 \mu \mathrm{m}$. C) Photograph of pre-pharyngeal section, scale bar: $500 \mu \mathrm{m}$.

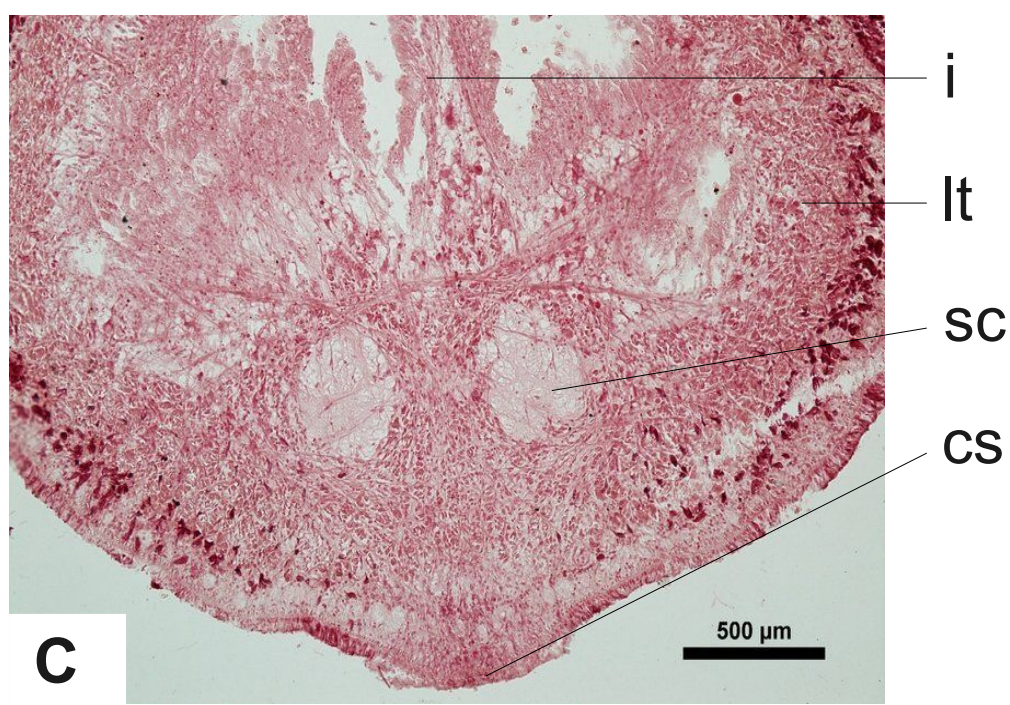


A

\section{Pelmatoplana moluccana} von Graff, 1899. Figure 52. Holotype. A) Reconstruction of the pharynx, scale bar: $500 \mu \mathrm{m}$. B) Photograph pharynx, scale bar: $500 \mu \mathrm{m}$. C) Photograph of pharnyx musculature, scale bar: 100 $\mu \mathrm{m}$. D) Photograph of pharynx musculature, scale bar: $100 \mu \mathrm{m}$.
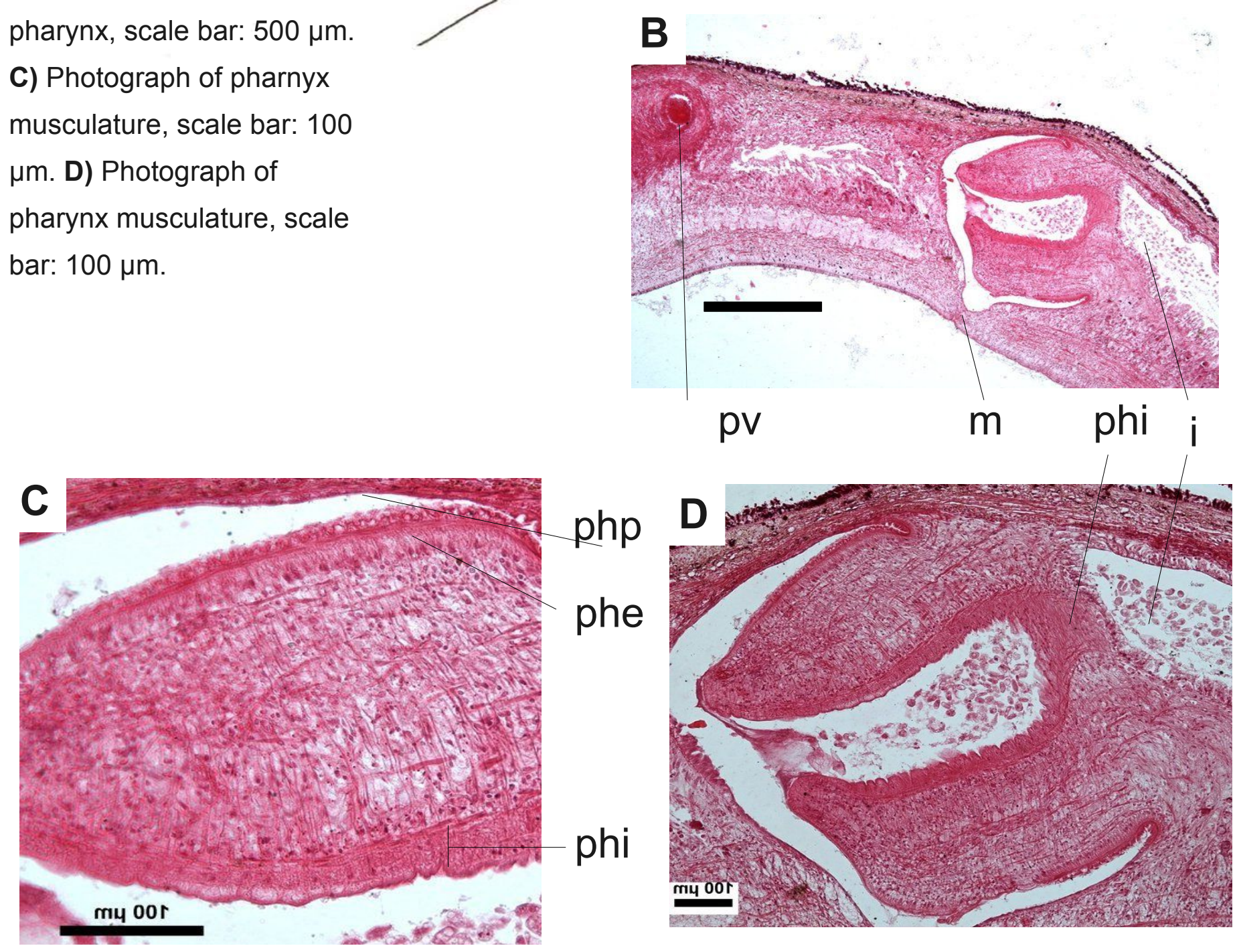

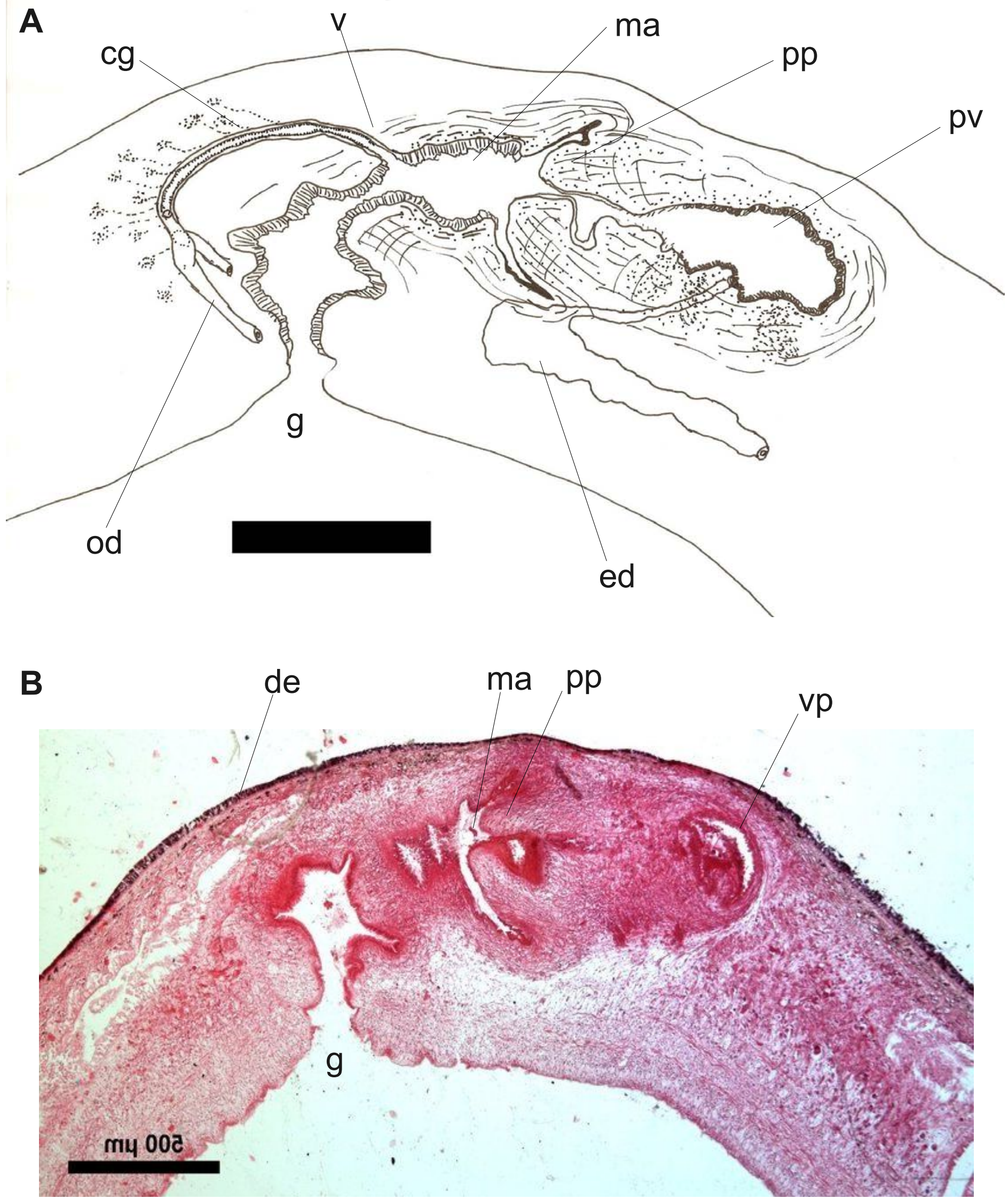

Pelmatoplana moluccana von Graff, 1899. Figure 53. Holotype. A) Reconstruction of copulatory apparatus, scale bar: $500 \mu \mathrm{m}$. B) Photograph of copulatory apparatus, scale bar: 500 $\mu \mathrm{m}$. 


\section{Polycladus gayi Blanchard, 1845}

\section{SYNONYM}

Geoplana gayi: Schultze \& Muller, 1857

\section{EXAMINED MATERIAL}

NHMW 2777: (Graff $n^{\circ} 157$ ) Anterior part, transversal sections in 78 slides; Anterior part 2, transversal sections in 140 slides; Copulatory apparatus, sagittal sections in 80 slides; Pre-pharyngeal region, transversal sections in 129 slides. F396: Pharynx, sagittal sections in 43 slides.

\section{MORPHOLOGY}

External morphology. Large and flat worm (Figure 54A). Creeping sole wide, about $90 \%$ body width. In the anterior end the eyes go around the anterior tip in a single row. Sensory pits surrounding anterior tip in a single row. Sensory pits distributed on multiple rows per side, being up to three sensory pits on one side.

Sub-epidermal musculature. Tripartite sub-epidermal musculature, with all three layers very well developed (Figure 54B, 54F). Double diagonal packed in bundles and reaching almost he height of the longitudinal bundles in transversal sections (Figure 54C). Longitudinal bundles packed in tall, thin and separate bundles. The ventral sub epidermal musculature seems to divided into two different layers; an outer layer of short and closely packed bundles, and an inner layer of bundles containing long fibers. The longitudinal layer is not insunk into the mesenchym. In the anterior region the dorsal longitudinal bundles seem to be stronger that the ventral.

Sub-epidermal secretions. Epidermis tall columnar and nucleated, apically eophilic and secreting cyanophyll secretions that are embedded in the longitudinal musculature. Rhabditogen cells abundant dorsally, located under the longitudinal musculature. At the border the sub-epidermal musculature becomes inconspicuous and there are accumulations of cyanophyll secretions on the border that resemble a glandular ridge.

Mesenchymal musculature. Mesenchymal musculature disposed with fibers in all direction but mainly gathering in five separate layers; dorsal double diagonal, transversal sub-intestinal, transversal supra-intestinal, decussate sub-neural (Figure 54D). Sub-neural musculature arranged in crisscross disposition (Figure 54E). Mesenchymal longitudinal fibers absent. Mesenchymal transversal sub-neural absent in anterior tip. 
Digestive system. Pharynx incompletely mounted in studied specimens.

Central nervous system. Central nervous system very flat and widespread.

Male reproductive organs. Testes irregular in form, distributed as many as 4-5 testes per side. Placed directly underneath the transversal supra-intestinal, with a few fibers of the transversal supra-intestinal running below the testes. The efferent duct run posteriorly and curve in an anterior dorsal direction and separately open into the Prostatic vesicle. Efferent ducts with flat epithelium wrapped in circular musculature. The Prostatic vesicle sits in a rather vertical angle. Its shape composed of a tubular aspect about $1800 \mu \mathrm{m}$ long by $360 \mu \mathrm{m}$ thick and slowly extends to form a thin ejaculatory duct. The prostatic vesicle is located outside the common muscular coat. Prostatic vesicle musculature composed of fibers in all directions, but predominantly circular. Surrounded and penetrated by granular erytrophyll secretions. The ejaculatory duct opens through the tip of the penis papilla. The penis papilla is large and occupies the entire male atrium (Figure 55B). Penis papilla composed of an external circular musculature and internal longitudinal (Figure 55C). Male atrium with basophyll secretions, Lined with tall columnar and nucleated epithelium. Male atrium musculature composed of outer double diagonal and inner circular.

Female reproductive organs. Ovaries globular measuring about $400 \mu \mathrm{m}$ wide. The ovaries are placed above mesenchymal transversal sub-intestinal. The oviducts arise from the dorsal side of each ovary. Oviducts located above sub-intestinal transversal and coated with double diagonal musculature. Multicellular yolk funnels opening to ovoviteline ducts through the length of these. Ovoviteline ascending, anterior to the gonopore, in a 45 degree angle and receiving shell gland in the last $2 / 5$ of its extension. In the last portion of the oviducts it is possible to observe a two layer muscular arrangement of the oviducts: outer crisscross and inner longitudinal. Vagina positioned dorsally, in the most posterior corner of the female atrium. Ovovitelline ducts approach separately from below. Vagina musculature composed of reticulate muscle fibers. Female atrium small, about $1 / 4$ the size of the male atrium (Figure 55A). Musculature composed of circular and longitudinal fibers. Epithelium flat cuboidal. Common muscular coat wrapping the entire copulatory apparatus with exception of the prostatic vesicle. 

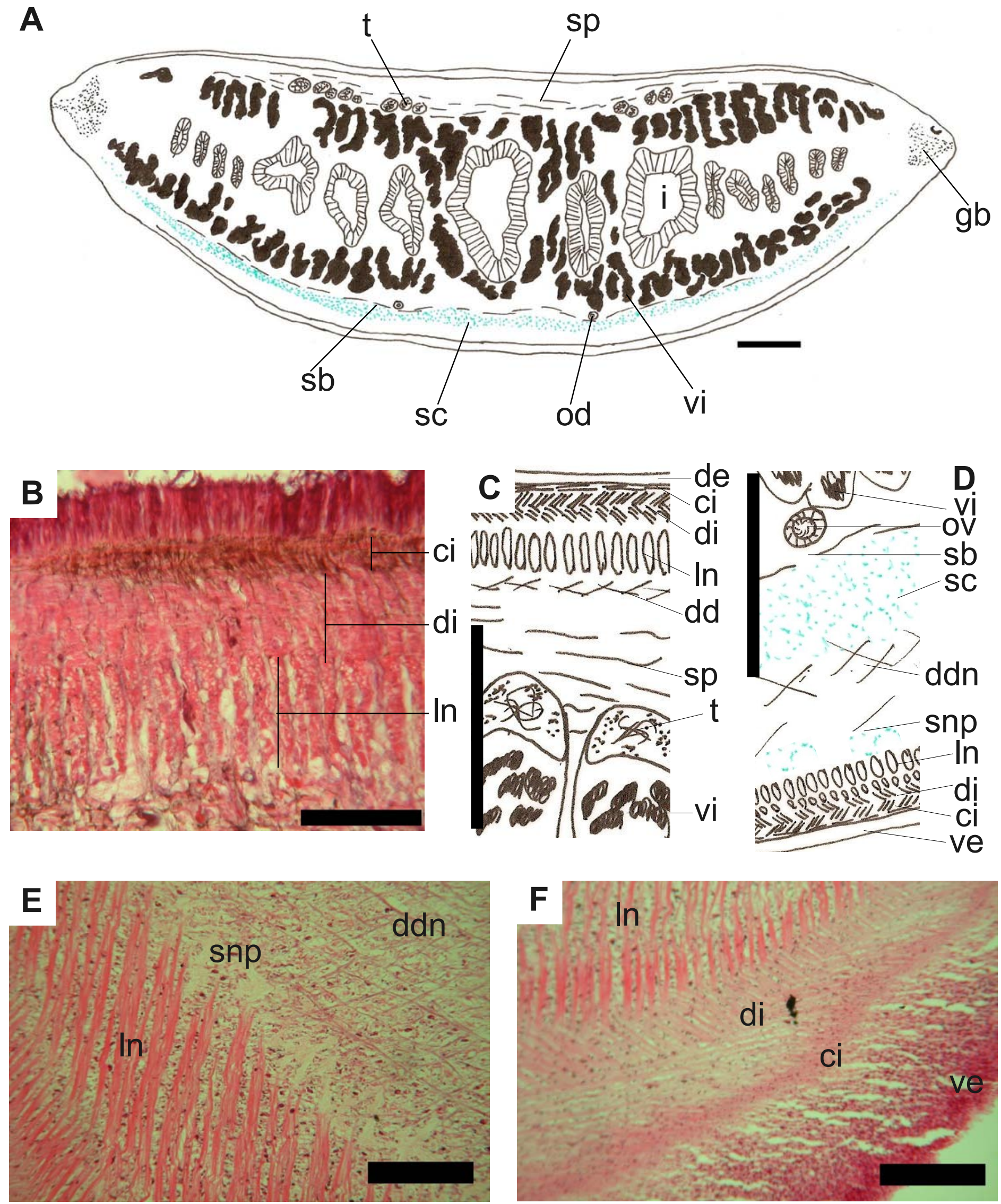

Polycladus gayi Blanchard, 1845. Figure 54. Specimen NHMW 2777. A) Reconstruction of prepharyngeal section, scale bar: $1 \mathrm{~mm}$. B) Photograph of dorsal sub-epidermal musculature, scale bar: $1 \mathrm{~mm}$. C) Drawing of dorsal sub-epidermal musculature, scale bar: $500 \mu \mathrm{m}$. D) Drawing of ventral sub-epidermal musculature, scale bar: $500 \mu \mathrm{m}$. E) Photograph of frontal section of subneural double diagonal musculature, scale bar: $200 \mu \mathrm{m}$. F) Photograph of frontal section of ventral sub-epidermal musculature, scale bar: $200 \mu \mathrm{m}$. 

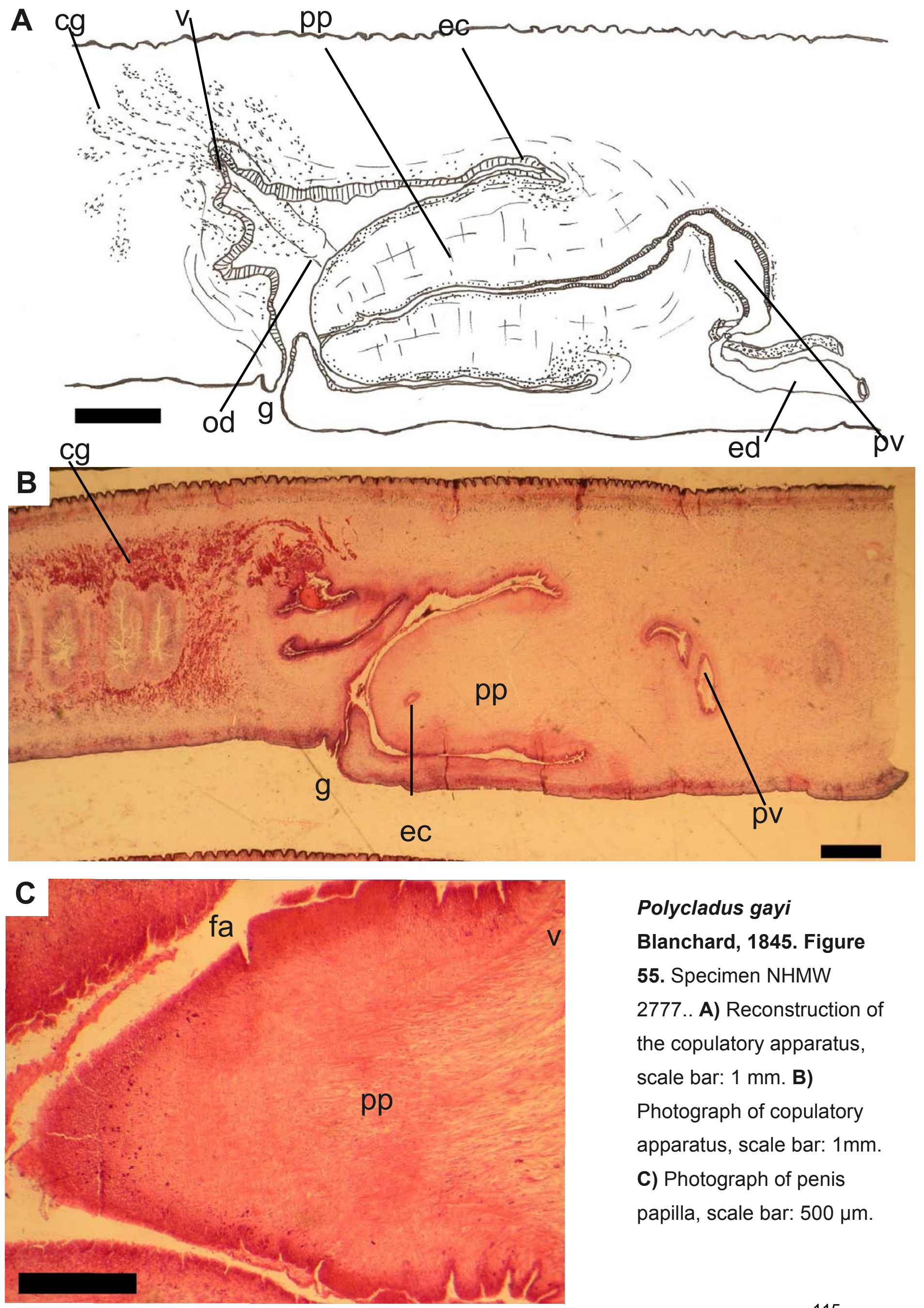

Polycladus gayi

Blanchard, 1845. Figure

55. Specimen NHMW

2777.. A) Reconstruction of

the copulatory apparatus,

scale bar: $1 \mathrm{~mm}$. B)

Photograph of copulatory apparatus, scale bar: $1 \mathrm{~mm}$.

C) Photograph of penis

papilla, scale bar: $500 \mu \mathrm{m}$. 


\section{Supramontana irritata Carbayo et Leal-Zanchet, 2003}

\section{EXAMINED MATERIAL}

MZU 652: sagittal sections of anterior tip on 52 slides. transversal sections pre-pharyngeal region on 6 slides. sagittal sections of pharynx on 25 slides. sagittal sections of copulatory apparatus on 24 slides.

\section{MORPHOLOGY}

External morphology. Small flat worm (Figure 56A) with rounded anterior and poster ends. Creeping sole about $85 \%$ of body width. Eyes contouring anterior tip, anteriorly irregularly uniserial and marginal; further back, eyes spread to both sides of dorsal surface, scarcer towards posterior end. Sensory pits composed of simple invagination, $13 \mu \mathrm{m}$ deep, surrounding whole cephalic region in single row.

Sub-epidermic musculature. Tripartite musculature with longitudinal layer packed in bundles. Sub-epidermal longitudinal muscle bundes insunk into the mesenchym on the ventral side (Figure 56D). Ventral longitudinal layer $\sim 2.3 \times$ thicker than dorsal. In anterior region longitudinal musculature forming a cephalic retractor muscle.

Sub-epidermal secretions. Without a glandular margin. Cephalic glandular accumulations present. In anterior region rhabditogen cells scarce dorsally and abundant ventrally (Figure 56B).

Mesenchymal musculature. Mesenchymal musculature composed of a dorsal double diagonal layer and three transverse layers: supra-intestinal, sub-intestinal and sub-neural. Mesenchymal musculature in the anterior region same as in pre-pharyngeal region but thicker. Mesenchymal longitudinal fibers absent.

Digestive system. Mouth approximately located in anterior third of pharyngeal cavity. Bell-shaped pharynx, dorsal insertion posterior to mouth (Figure 57A). Pharynx highly folded in posterior end (Figure 57B). Esophagus very short. External pharynx musculature (Figure 57C), thin sub-epithelial longitudinal layer followed by thicker circular layer intermixed with longitudinal fibers. Internal pharynx musculature (Figure 57D) composed of thick circular subepithelial layer, followed by a thin longitudinal layer. Pharyngeal pocket composed of longitudinal and circular muscle fibers.

Nervous system. Central nervous system organized as a flat plate.

Male reproductive organs. Testes located dorsally underneath transversal supra- 
intestinal mesenchymal muscle layer (Figure 56C). Testes pre-pharyngeal, extending from the region of the ovaries in the anterior third to the pre-pharyngeal region. Each testicle communicated with the efferent duct through a thin dorso-ventral channel. Efferent ducts: open laterally onto proximal region of prostatic vesicle. Prostatic vesicle extra-bulbar (Figure $58 \mathrm{~A}$ ), unpaired, straight and dilated in proximal region. Distal of portion prostatic vesicle penetrates penis bulb and continues as ejaculatory duct on entering penis papilla. Penis papilla conical, with dorsal insertion slightly displaced posteriorly. Male atrium only partially occupied by penis papilla. Male atrium without folds (Figure 58B). Inter-atrial fold absent. Penis papilla composed of a $10 \mu \mathrm{m}$-thick circular layer, followed by longitudinal layer (Figure $58 \mathrm{C})$. Mesenchymal of papilla with longitudinal and radial muscle fibers.

Female reproductive organs. Ovaries elongated, dorsal to nerve plate. Ovaries placed underneath the transversal sub-intestinal mesenchymal layer. Ovovitelline ducts dorsal to nerve plate, emerge dorsally from ovaries; at level of gonopore they curve dorso-medially. Openings of shell glands onto distal quarter of ascending course. Common ovovitelline duct very long directed posteriorly, dorsal to female atrium, with distal portion curved ventrally. Vagina short, slightly curved dorso-anteriorly, communicating with proximal region of female atrium. Female atrium epithelium pseudoratified. Female atrium length half that of male. Common muscular coat encompassing distal portion of prostatic vesicle, male and female atria and vagina. 
A

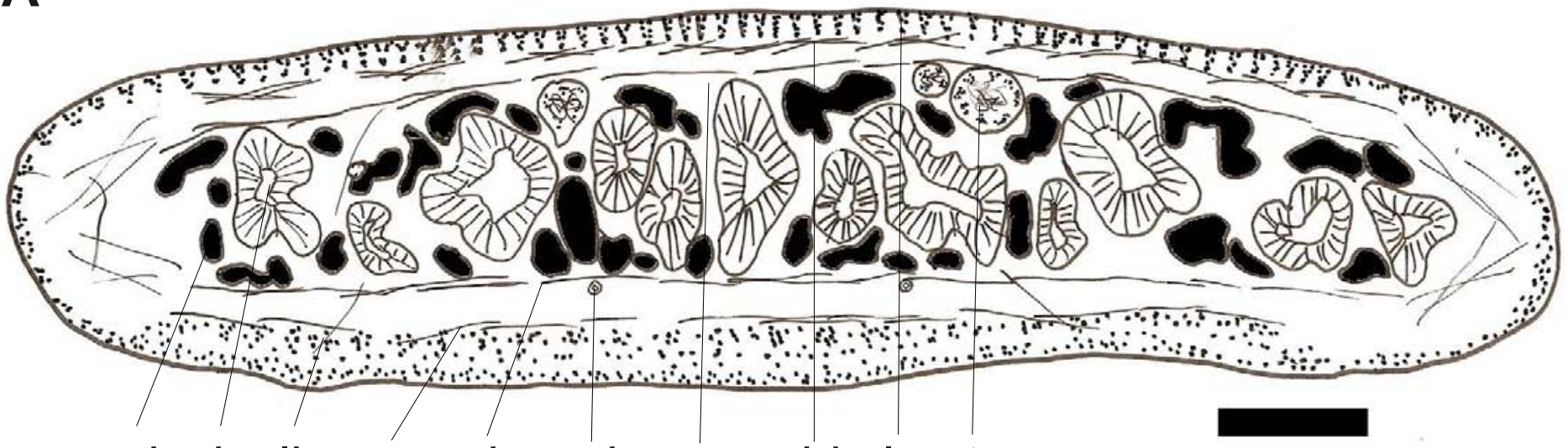

vi i li sn sb od sp dd In $t$

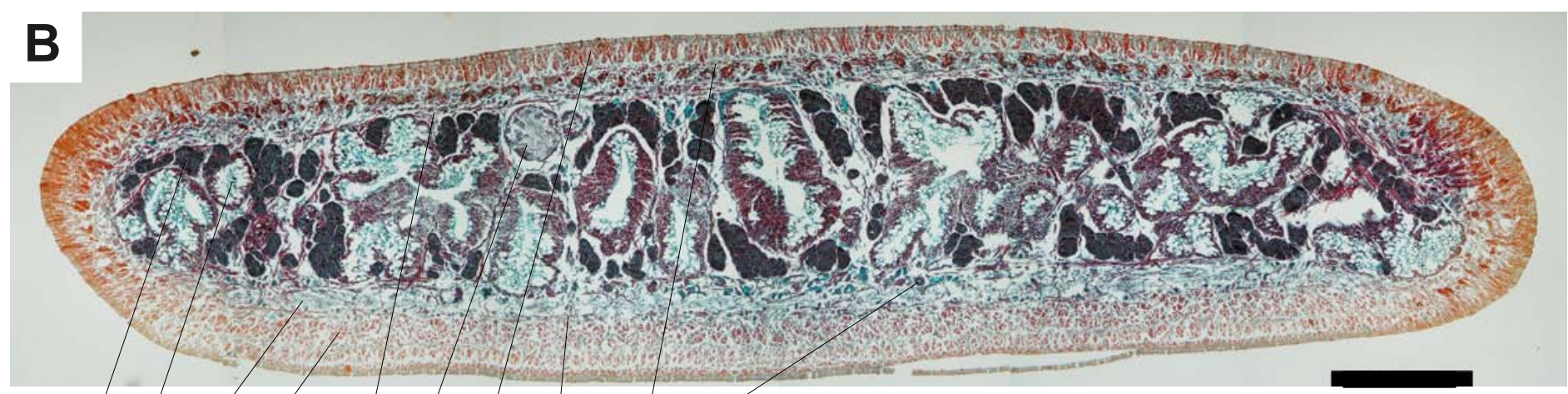

vi i sc li sp t In sn dd od
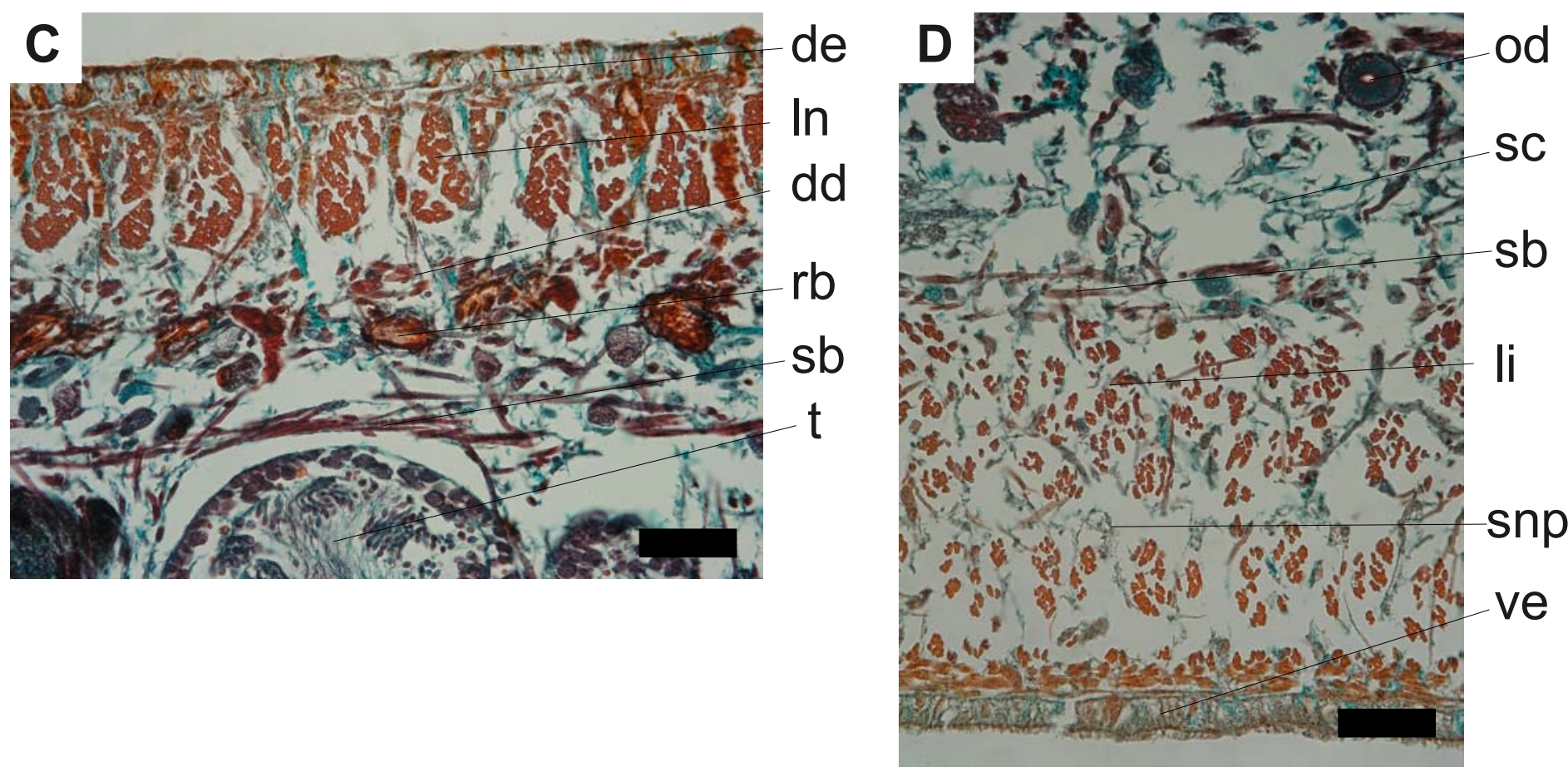

Supramontana irritata Carbayo et Leal-Zanchet, 2003. Figure 56. Specimen MZU 652. A) Reconstruction of section of the pre-pharyngeal region, scale bar: $500 \mu \mathrm{m}$. B) Photograph of section of the pre-pharyngeal region, scale bar: $500 \mu \mathrm{m}$. C) Photograph of dorsal sub-epidermal musculature, scale bar: $50 \mu \mathrm{m}$.D) Photograph of ventral sub-epidermal musculature, scale bar: 50 $\mu \mathrm{m}$. 
A
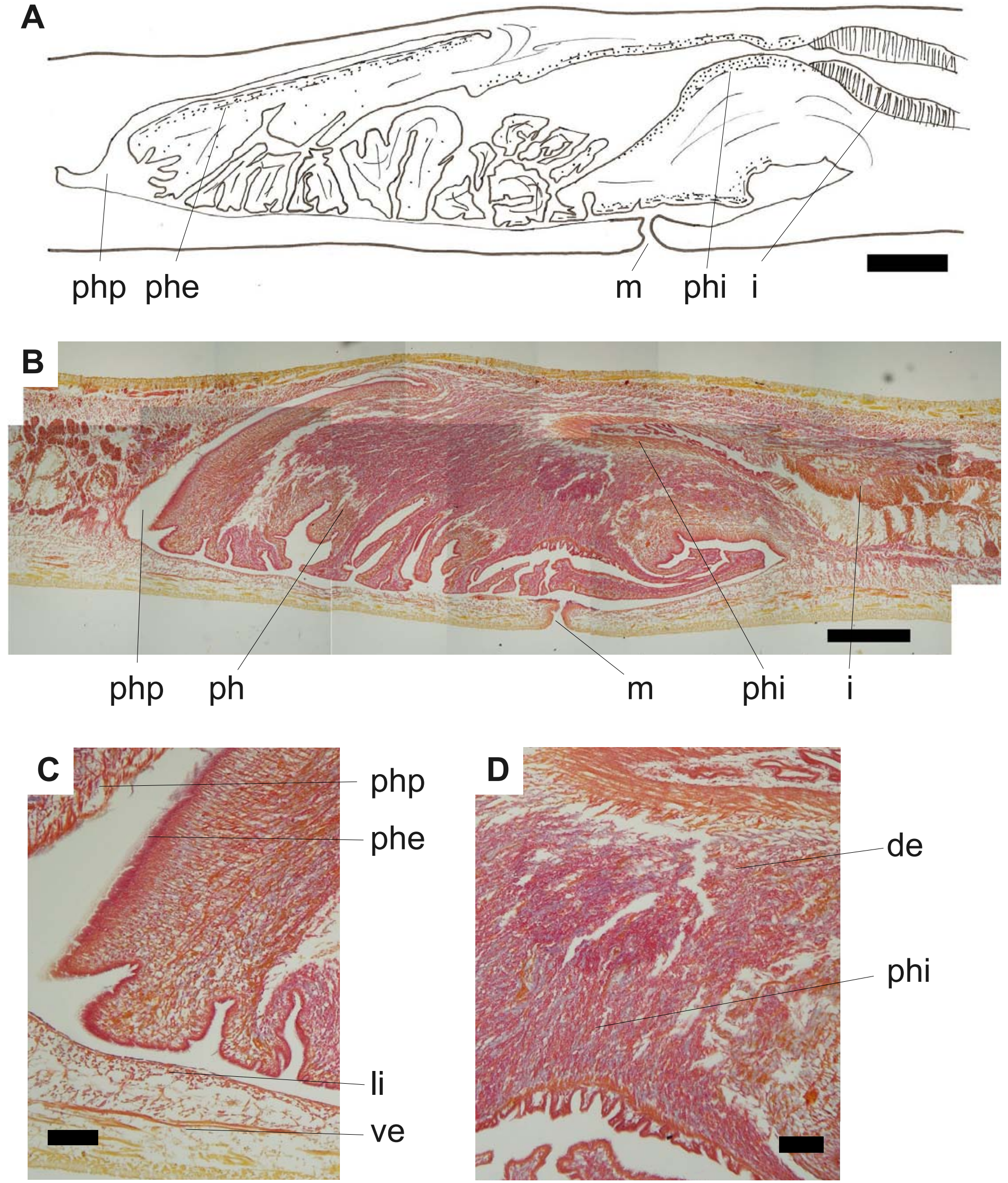

Supramontana irritata Carbayo et Leal-Zanchet, 2003. Figure 57. Specimen MZU 652.

A) Reconstruction of pharynx, scale bar: $500 \mu \mathrm{m}$. B) Photograph of pharynx, scale bar: $500 \mu \mathrm{m}$. C) Photograph of external pharyngeal musculature, scale bar: $100 \mu \mathrm{m}$. D) Photograph of internal pharyngeal musculature, scale bar: $100 \mu \mathrm{m}$. 

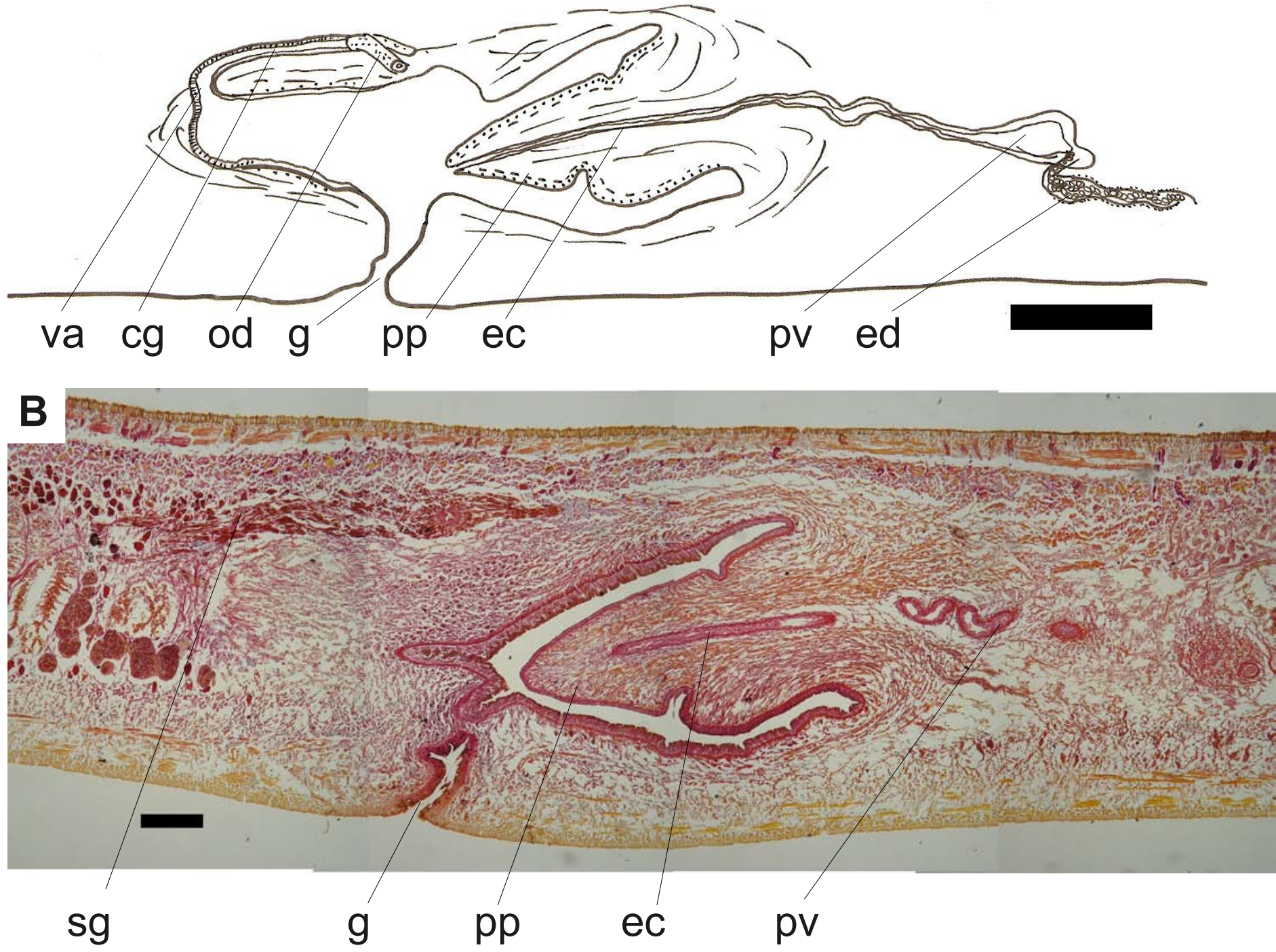

Supramontana irritata

Carbayo et Leal-

Zanchet, 2003. Figure

58. Specimen MZU

652. A) Reconstruction

of copulatory

apparatus, scale bar:

$500 \mu \mathrm{m}$. B)

Photograph of

copulatory apparatus, scale bar: $500 \mu \mathrm{m} \mathrm{C)}$

Photograph penis

papilla, scale bar: 100

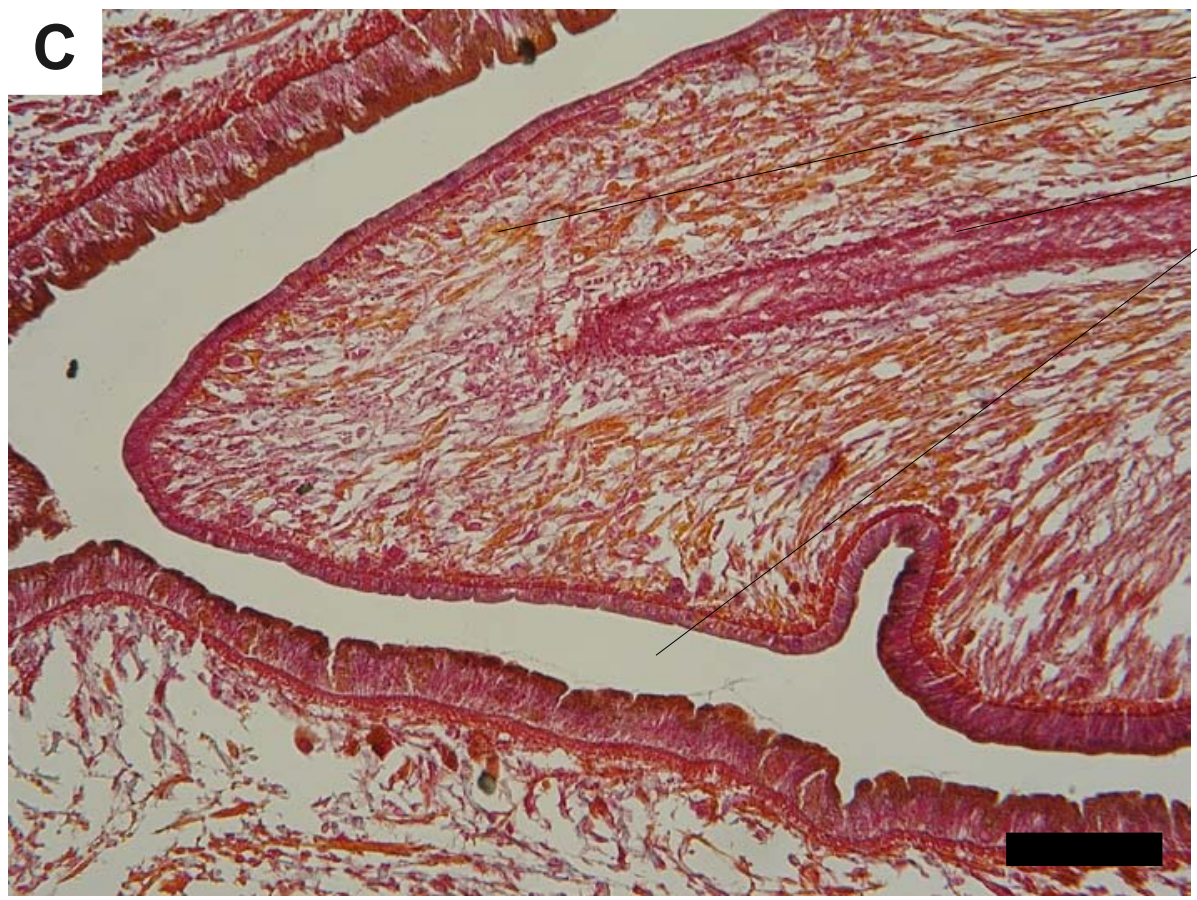

$\mu \mathrm{m}$. 


\section{Xerapoa hystrix C.G. Froehlich, 1955}

\section{EXAMINED MATERIAL}

EMF X. hystrix (Curitiba VI/1953): Anterior part, transversal sections in 2 slides; Pre-pharynx region, transversal sections in 2 slides. Pharynx and copulatory apparatus, sagittal sections in 1 slide. EMF $\mathbf{X}$. hystrix (22/IV/1953): Anterior part, transversal sections in 3 slides; Anterio part 2, sagittal sections in 2 slides; Prepharynx region, transversal sections in 4 slides. EMF X. hystrix (20/ll/1952): Anterior part, transversal sections in 2 slides. Pharynx and copulatory apparatus, sagittal sections in 1 slide. EMF X. hystrix (3/IV/1952): Anterior part, transversal sections in 2 slides. EMF X. hystrix (10/II/1954): Anterior part, transversal sections in 2 slides. EMF X. hystrix (1952): Pharynx and copulatory apparatus, sagittal sections in 1 slide. EMF X. hystrix (27/3/1952): Anterior part, transversal sections in 1 slide.

\section{MORPHOLOGY}

External morphology. Small cylindrical worm. Creeping sole half of body width. In the cephalic region creeping sole greatly reduced to a thin line in the middle of the body. Eyes about $30 \mu \mathrm{m}$ in diameter, distributed in a single lateral row, spacing backwards. In the cephalic region they seem to be associated with the sensory papillae occurring frequently in the base of these (Figure 59A). Sensory pits located in at the apex of the sensory papillae and are lined with epithelium of insunk nuclei (Figure 59B). Sensory papillae composed of an external circular and an internal longitudinal. Mesenchymal transversal and longitudinal fibers insert into the base of the papillae.

Sub-epidermal musculature. The cutaneous musculature is tripartite, slightly stronger dorsally than ventrally. The dorsal fibers are of greater diameter and are gather in taller bundles than the ventral fibers.

Sub-epidermal secretions. Cyanophyll glands open thought the whole body surface. Granulouse cyanophyll glands opening predominantly dorsal and lateral. Glandular keel (Figure 60B) composed of erytrophyll glands of irregular secretion and large gland accumulations. Keel gland bodies located between the intestine and above the nervous system, the ducts open through the two nerve chords. Rhabdites occurring in the whole epidermis, but in lesser degree in the venter.

Mesenchymal musculature. Mesenchymal musculature weak. Dorsal double diagonal very inconspicuous, transversal supra-intestinal and transversal sub-intestinal. Longitudinal fibers very weak composed of a few isolated fibers occurring near the intestine, specially on the ventral side. 
Digestive system. Mouth located in the posterior half of the pharyngeal pocket (Figure 61A). The pharynx is of cylindrical shape, with the dorsal insertion slightly posterior to the ventral. The pharynx presents small longitudinal folds. Esophagus present, about one third the length of the pharynx (Figure 61B). External pharynx musculature composed of two very thin layers of longitudinal and circular fibers. Internal pharynx musculature composed of a sub-epithelial circular musculature intermixed with a few longitudinal fibers (Figure 61C).

Central nervous system. Nervous system concentrated in two longitudinal chords. In the anterior region the nervous system is well developed occupying great part of the transversal sections.

Male reproductive organs. Testes dorsally located, distributed in single line on each side of the intestines. Extending from the beginning of the cephalic region, anterior to the ovaries, to the base of the pharynx. Each testicle communicated with the efferent duct through a thin dorso-ventral channel. Efferent ducts located above the nervous system and lateral to the ovovitelline ducts. The efferent ducts expand and make a s like fold and insert in the lower extremity of the prostatic vesicle. Efferent ducts with flat epithelium wrapped in circular musculature. No glands associated. The prostatic vesicle is a curved tube-like cavity opening directly to the tip of the penis papilla (Figure 62B). The lumen of the distal portion of the prostatic vesicle bear longitudinal folds. The penis papilla is conical shaped and muscular. Prostatic vesicle with tall epithelium. Covered by dense circular muscular coat (Figure 62C).

Female reproductive system. Ovaries placed over transversal sub-intestinal mesenchymal layer behind anterior third of the body. Ovovitelline rise from the external face of the ovaries. Ovaries and oviducts placed above transversal sub-intestinal mesenchymal layer (Figure 60A). Ovovitelline run dorsally and rise posterior to the gonopore, connecting at the same time with the vagina. Female atrium without specialized epithelia. Each ovovitelline ducts ascend a few $\mathrm{mm}$ before the gonopore and opens directly to the vagina. Shell glands being delivered mainly on the vagina. Vagina located at the posterior end of the female atrium the lower half of body height. The female atrium is reduced to a thin tube about the diameter of the ovovitelline ducts, that extends horizontally (Figure 62A). Female atrium flat epithelium, erytrophyll secretions: Female atrium musculature this layer of circular with a few longitudinal fibers. 
A
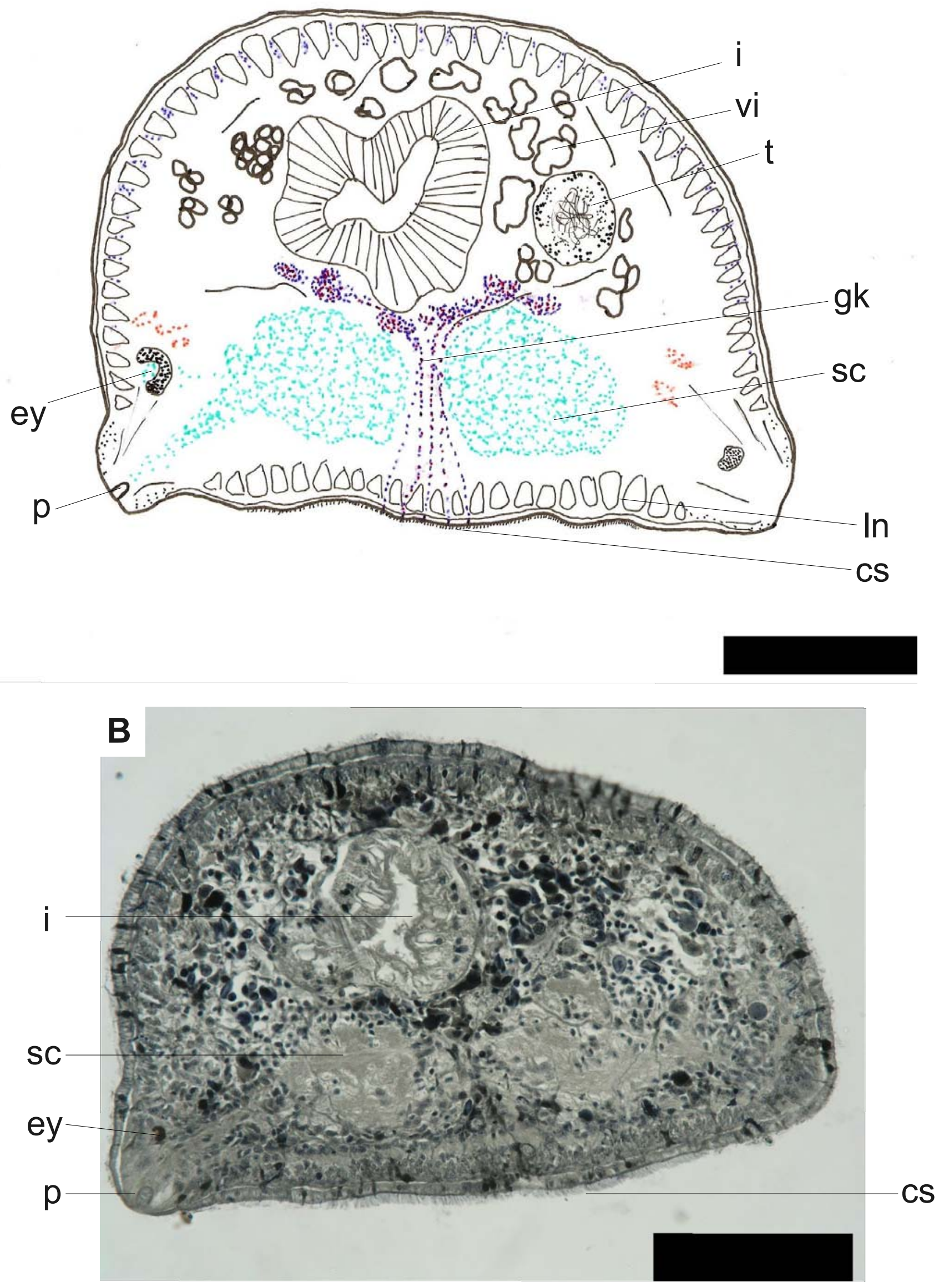

Xerapoa hystrix C.G. Froehlich, 1955. Figure 59. Specimen EMF X.h. 10/l1/54. A)

Reconstruction of section of anterior part, scale bar: $100 \mu \mathrm{m}$. B) Photograph of section of anterior part, scale bar: $100 \mu \mathrm{m}$. 

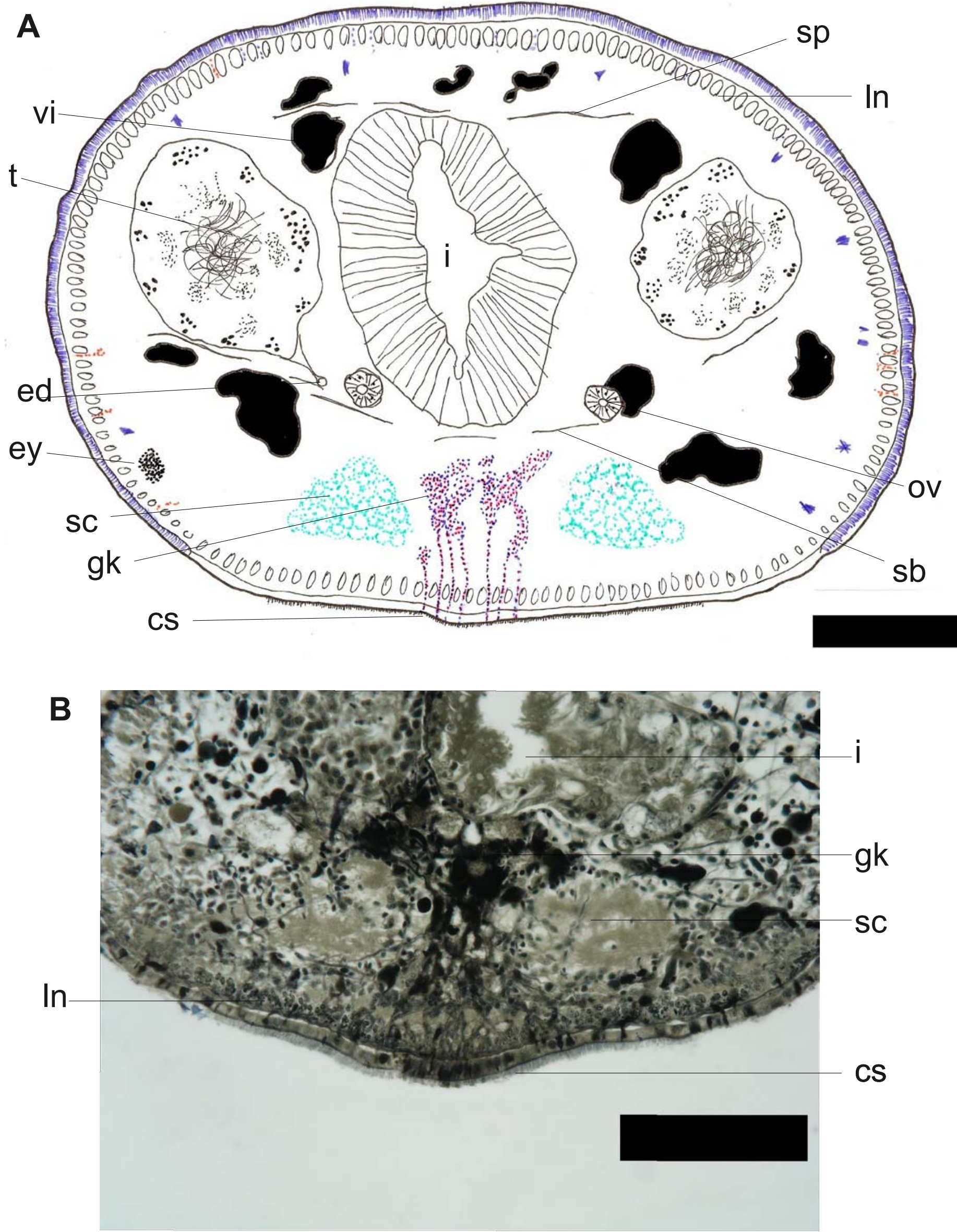

Xerapoa hystrix C. G. Froehlich, 1955. Figure 60. Specimen EMF X.h. 22/IV/1953. A)

Reconstruction of pre-pharyngeal section, scale bar: $100 \mu \mathrm{m}$. B) Photograph of glandular keel, scale bar: $100 \mu \mathrm{m}$. 

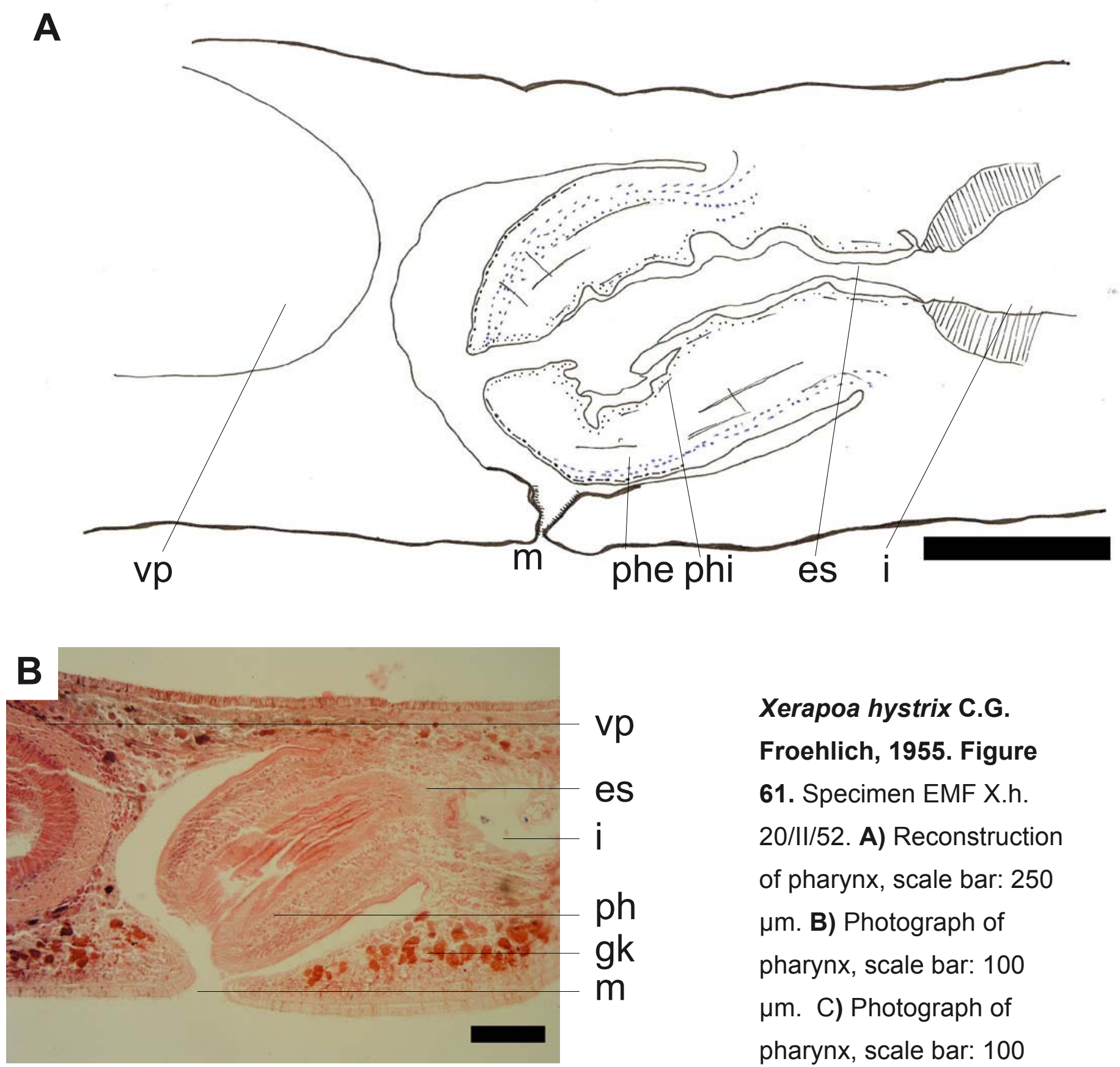

Xerapoa hystrix C.G. Froehlich, 1955. Figure 61. Specimen EMF X.h. 20/II/52. A) Reconstruction of pharynx, scale bar: 250 $\mu \mathrm{m}$. B) Photograph of pharynx, scale bar: 100 $\mu \mathrm{m}$. C) Photograph of pharynx, scale bar: 100 $\mu \mathrm{m}$.

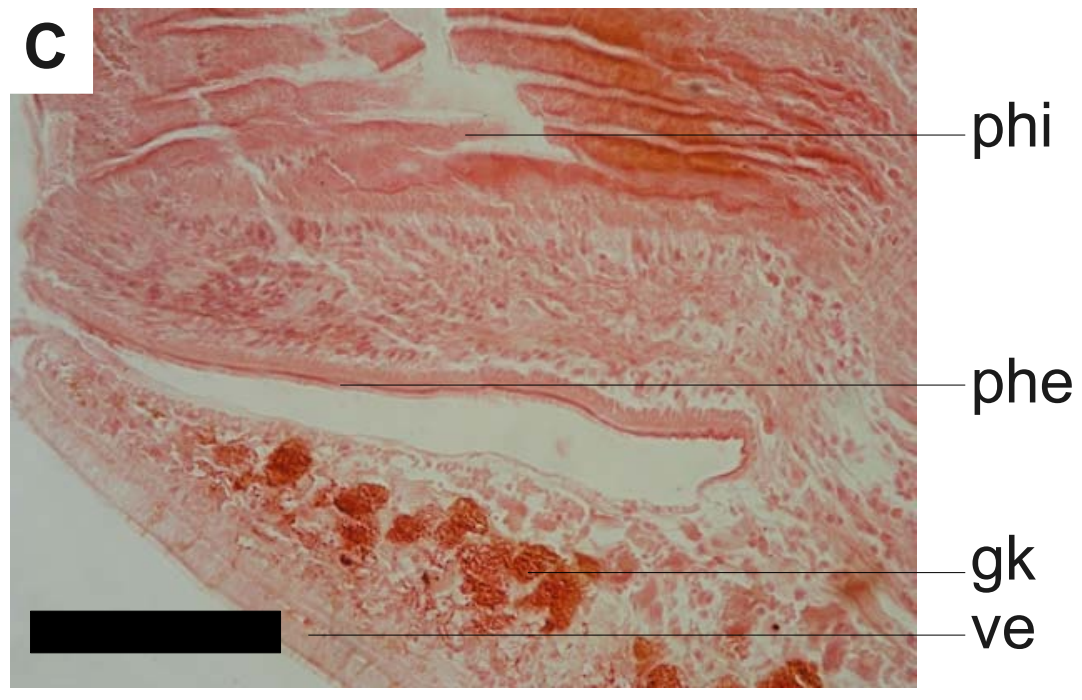


A
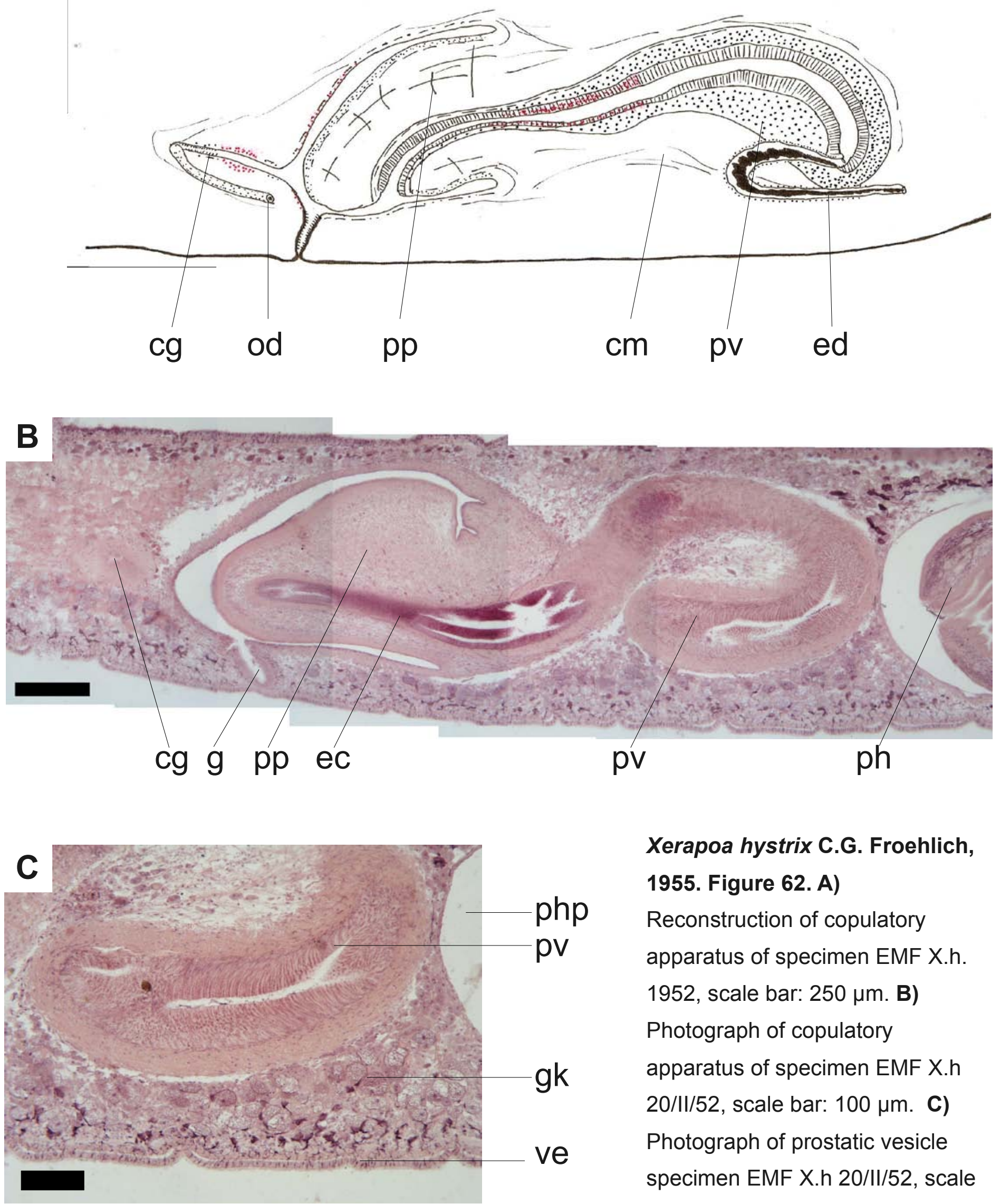

Xerapoa hystrix C.G. Froehlich, 1955. Figure 62. A)

Reconstruction of copulatory

apparatus of specimen EMF X.h.

1952, scale bar: $250 \mu \mathrm{m}$. B)

Photograph of copulatory

apparatus of specimen EMF X.h

20/II/52, scale bar: $100 \mu \mathrm{m}$. C)

Photograph of prostatic vesicle specimen EMF X.h 20/II/52, scale bar: $100 \mu \mathrm{m}$. 


\section{General conclusions}

The examination of the type material and additional material of Geoplaninae has revealed some unregistered morphological characters that should later have taxonomic consequences. The descriptions and the figures presented in this chapter could serve a basis for further characterizing each respective genus. The generic diagnosis of the genera that constitute the Geoplaninae should be re-evaluted taking into account the morphological details of the type species presented herein.

\section{References}

Ball, I. R. 1974. A contribution to the phylogeny and biogeography of freshwater triclads (Platyhelminthes, Turbellaria) In. Riser NW, Morse MP (eds). Biology of turbellaria McGraw-Hill, New York, pp 339-401.

Carbayo, F. 2003. Revisión de Notogynaphallia Ogren \& Kawakatsu, 1990 (Platyhelminthes, Tricladida) . Tese de doutorado. Universidad de Salamanca.

Carbayo, F. 2005. Procedimentos de campo e laboratório para a caracterização das planárias terrestres neotropicais (Platyhelminthes: Tricladida). Caderno La Salle XI, Canoas, 2 (1): 131-144.

Carbayo, F. \& Leal-Zanchet, A.M. 2003. Two new genera of Geoplaninae (Terricola: Tricladida: Platyhelminthes) of Brazil in the light of cephalic specialisations. Invertebrate Systematics, 17 (3): 449-468.

Froehlich, C.G. 1967. A contribution to the zoogeography of neotropical land planarians. Acta Zoologica Lilloana 23: 153-162.

Hyman, L. 1962. Some land planarians from Caribbean countries. American Museum Novitates 2110: 1-25.

Ogren, R.E. 1995. Predation behaviour of land planarians. Hydrobiologia, 305: 105-111.

Winsor, L. 1998. Collection, handling, fixation, histological and storage procedures for taxonomic studies of terrestrial flatworms (Tricladida: Terricola). Pedobiologia 42: 405411. 


\section{Capítulo 3}

Towards a phylogenetic classification of the Geoplaninid land planarians: a morphological analysis 


\section{Towards a phylogenetic classification of the Geoplaninid land planarians: a morphological analysis}

José Horacio Grau ${ }^{1,2}$, Ronald Sluys ${ }^{3}$ and Fernando Carbayo ${ }^{1,4}$

${ }^{1}$ Instituto de Biociências, Departamento de Zoologia, Universidade de São Paulo (USP), Rua do Matão, trav. 14, n321 Cidade Universitária, São Paulo - SP, Brazil.

${ }^{2}$ Museum für Naturkunde Berlin, 10115 Berlin, Germany.

${ }^{3}$ Institute for Biodiversity and Ecosystem Dynamics \& Zoological Museum, Universiteit van Amsterdam, P.O. Box 94766, 1090 GT Amsterdam, The Netherlands.

${ }^{4}$ Escola de Artes, Ciências e Humanidades, Universidade de São Paulo, Av. Arlindo Bettio, 1000. São Paulo - SP. 03828-000 Brazil.

\section{ABSTRACT}

The results corroborate the monophyletic status of the subfamily Geoplaninae. According with Meixner's hypothesis, a clade formed by Enterosyringa and Xerapoa species, sharing morphological characteristics with outgroup species, is the sister group of all other Geoplaninae species. We found that anatomical features of the copulatory apparatus, such as the presence and type of penis papilla showed many reversions and were not phylogenetically informative. Characters of the muscular system can be used much better for defining taxonomic groups within the Geoplaninae and as indicators of their evolutionary relationships. None of the present diagnostic features of the Geoplaninae formed autapomorphic characters in our analysis. Our results suggest that several genera of Geoplaninae represent unnatural groups, viz., Geoplana and Notogynaphallia, with some diagnostic characters being homoplasic.

\section{INTRODUCTION}

The Tricladida (Platyhelminthes) or planarians are free living flatworms characterized by three intestinal branches, and ectolecithal eggs (Hyman, 1951). Today there are three suborders of Triclads, indicated by names refer to their ecology; marine planarians (Maricola Hallez, 1892 ), fresh water planarians plus terrestrial planarians (Continenticola Carranza et al, 1998), and cave planarians (Cavernicola Sluys, 1990). 
Land planarians (family Geoplanidae) belong to the soil ecosystem. They live in humid environments of the forest floor and often exhibit bright colouration patterns. They range between 1 to $20 \mathrm{~cm}$ in size and are successful predators of other invertebrates (Ogren 1995). The animals lack mechanisms for retaining water and because of this they are sensible to the humidity variations of their environment (Kawaguti, 1932). Because of their low vagility and their narrow ecological requirements land planarians have been proposed to be used as indicator taxon in conservation studies (Sluys, 1999; Carbayo et al., 2002).

The family Geoplanidae is composed of four subfamilies: Rhychodeminae Von Graff 1896 and Microplaninae Pantin 1953, characterized by two eyes at the anterior end of the body; Bipaliinae Von Graff, 1896 subfamily, comprising species with a characteristic expanded head; the Geoplaninae Stimpson 1857, characterized by having dorsal testes and multiple dorsal eyes. The latter subfamily of land planarians is the focus of the present paper.

Very little is known about the phylogeny of land planarians. The first phylogenetic proposal of the Geoplanidae is that of Von Graff (1899). He based his phylogenetic hypothesis on (a) the creeping sole and its glandular specializations, (b) the nervous system, (c) development of the mesenchymal musculature and (d) eye distribution. He regarded that the animals with a broad creeping sole represented the primitive form, less adapted to life on land in contrast to those with thin creeping soles, which were presumably better adapted to the terrestrial habitat. According to Von Graff, the genus Geoplana (sensu Von Graff, 1899) represented a primitive Geoplanid taxon in which the mesenchymal musculature was poorly developed, the nervous system was less specialized, and the eyes had no fixed localization. Von Graff also considered that the copulatory apparatus of the Geoplana species represented a simple, non-adapted form. He argued that the Rhynchodemidae, with a thin secretive creeping sole, and more developed mesenchymal musculature represented a form that is better adapted to terrestrial locomotion. Von Graff argued that the Bipaliidae arose from an oriental Geoplana group that is presently known as the Caenoplanini Ogren \& Kawakatsu 1991 tribe.

The second major phylogenetic study of the Geoplanidae comes from Meixner (1928), a student of Von Graff. Meixner's proposal is basically the opposite of Von Graff's because he considered that if cutaneous musculature was the primary terrestrial locomotion organ, then the Geoplaninae would be the most terrestrialized group as they bear well-developed bundles of cutaneous muscle. Meixner also compared the copulatory bursa across Maricola, Paludicola and Terricola and stated that terrestrial planarians with a bursa, such as the 
Rhynchodemini and Microplaninae, represent the most primitive forms. Although Meixner did not provide phylogenetic relationships among the Geoplanidae, he proposed taxonomic groups and presented a discussion on the putative sister taxon of the Geoplanidae defending Hallez's (1892) proposal of a relationship between Geoplanidae and Maricola. Neither Von Graff nor Meixner were conclusive whether the land planarians had branched from a freshwater or marine ancestor, nor whether terrestrialization had occurred only once or several times during the evolution of triclad flatworms.

The terrestrialization of planarians has only recently been examined and a water-landwater transition scenario has been proposed for them (Álvarez-Presas et al., 2008). In the past ten years molecular studies provided new insights into Triclad evolution that have concluded with a new higher classification of the planarian flatworms (Sluys et al., 2009). Although the placement of the Geoplanidae as sistergroup of Dugesiidae is supported by molecular evidence (Carranza et al., 1998; Álvarez-Presas et al., 2008), the discussion on the interrelationships of the terrestrial planarians has barely begun.

Unfortunately, currently there is a taxonomical obstacle that hinders the construction of a modern classification of the land planarians: poor morphological knowledge of the species in general and of type species in particular. Furthermore, generally there are only few type specimens available, and they are hard to obtain and to study. The majority of type specimens has been deposited many decades ago in museums throughout the world frequently their current condition is far from optimal for histological study.

The generic diagnoses of the 16 genera of the Geoplaninae generally include only a combination of gross morphological features of the copulatory apparatus, with the remaining body regions almost unstudied (Carbayo \& Zanchet 2003) Furthermore, the studied body regions of most planarians are very seldom detailed enough to establish evolutionary or biogeographic discussions. As a consequence, for most of the current genera there are no putative apomorphic characters, but only a combination of shared characters of which the phylogenetic value is not known.

Because not all of these diagnoses are based on apomorphies, a phylogenetic classification of the Geoplaninae is presently very hard to undertake without re-analysing the type material. A phylogenetic approach is needed in order to examine which morphological characters may be used as presumed apomorphic features in modern, phylogeny-based diagnoses of supra-specific taxa. Therefore, the aim of this study is to examine the phylogenetic relationships between these genera with the help of a morphological data set. As 
exemplar taxa for this analysis we have used (1) the type species of each nominal genus when possible, and (2) some additional available species for several of the genera.

\section{MATERIALS AND METHODS}

In order to establish a strong basis for future land planarian researches, we have examined in most cases the complete morphology of the type species of the genera of the Geoplaninae. Only the type species, Polycladus gay Blanchard 1845, Liana guasa E. M. Froehlich 1978 and Geoplana gigantea Von Graff, 1899 were not included in the analysis, as type material was not sufficiently complete for examination. Additional non-type species of Amaga Ogren \& Kawakatsu 1990, Geoplana Stimpson, 1857 and Notogynaphallia Ogren \& Kawakatsu 1990 were also added. We also included as outgroups representative for the other subfamilies and tribes of the Geoplanidae. We studied species of the tribes Pelmatoplanini, Anzoplanini, Caenoplanini, Bipaliini and also studied Dolichoplana carvalhoi Correa, 1947 as exemplar species of the Rhynchodemini tribe. We have also been able to include several species of Notogynaphallia mainly because of the availability of the material from Carbayo's (2003) study. The analysis was rooted in Dugesiidae, presumed sistertaxa to the Geoplanidae (Carranza et al., 1998; Álvarez-Presas et al., 2008).

A data matrix (Table 1) of morphologically informative characters was compiled from the literature and supplemented by microscopical analysis of histological serial sections of our selected species. Morphological data was entered into a data matrix through Delta Editor (Dallwitz, 1980; Dallwitz et al., 2009).

Characters were coded according to Sereno (2007). Neomorphic characters were preferred because they reduce the quantity of inapplicable character states, and thus enable the character list to be expanded, without modification of the characters, when including distant taxa in future analyses. Characters with more than $5 \%$ inapplicable characters were excluded from the analysis.

Phylogenetic analysis was performed with TNT (Goboloff et al., 2008). Tree search was performed under New Technology search, with default options to hit the minimum score 1000 times. Majority rule consensus trees were calculated at a 50\% cutoff. Consistency index of the characters are given in (Table 2). 


\section{RESULTS}

The $50 \%$ majority rule consensus tree (Figure 1 ) corroborates the monophyletic status of the Geoplaninae with the following presumed apomorphic characters: dorsal testes (Table 1, character 40); weak longitudinal mesenchymal musculature (characters 30-32); a strong bundle-packed cutaneous musculature (character 23).

Some new and interesting clades are also apparent from this tree. A clade formed by the Brazilian species Enterosyringa pseudorhynchodemus and Xerapoa hystrix sharing a sister relationship, is the sistergroup of all geoplaninids. The apomorphies supporting this clade are: rounded body (character 4), thin creeping sole (character 5); ovaries located above sub-intestinal mesenchymal muscle layer (character 63); ovaries placed posteriorly (character 65); nervous system constituted by two ventral nerve chords (character 68)(Figure 2).

The sympatric southern Chilean species Gusana cruciata (Von Graff, 1899) and Pseudogeoplana reticulata (Von Graff, 1899) forms another clade. Both species have their cutaneous musculature insunk on both the ventral and dorsal body surfaces (character 24), and also have branched sensory pits (character 18).

Gigantea maupoi Carbayo, 2008, Amaga amagensis (Fuhrmann, 1914), A. bogotensis (Von Graff, 1899) and Notogynaphallia andina (Hyman, 1962), all from Andean areas, constitute a clade supported by the following apomorphies: eyes extending on the dorsal surface of the body (character 13), bifurcated prostatic vesicle (character 49), prostatic vesicle external to the common genital muscular coat (character 47).

Another clade is formed by Geoplana tuxaua E.M. Froehlich 1955 and G. matuta E. M. Froehlich, 1955. They share an intra-penial prostatic vesicle (character 48 ), as well as a stratified epithelium in the female atrium (character 59).

A sister relationship between Notogynaphallia goetschi sensu Marcus, 1951 and $N$. guaiana Leal-Zanchet \& Carbayo, 2001 is supported by a unique feature, i.e., bundles of mesenchymal longitudinal musculature surrounding the intestine (character 30 ), and also by a female atrium lined with a pluristratified epithelium (character 59).

The clade formed by Pasipha pasipha (Marcus 1951), Notogynaphallia octostriata (Schultz \& Müller, 1867), N. mourei (Froehlich, 1956) and N. plumbea (Froehlich, 1956) is supported by the musculature of the male atrium (character 55 ). The clade constituted by these three Notogynaphallia species is supported by the absence of an ejaculatory duct (character 50)(Figure 2C), and the arrangement of the internal pharynx musculature (character 38)(Figure 2A). 
A well supported clade, native to southeastern Brazil, is formed by Notogynaphallia caissara (E.M. Froehlich, 1956), N. fita (Froehlich, 1959), N. ceciliae (E.M. Froehlich \& LealZanchet, 2003) and N. nataliae (Froehlich, 1959) together with Issoca rezendei (Schirch, 1929), Choeradoplana iheringi Von Graff, 1899, Supramontana irritata Carbayo \& LealZanchet 2003, Cephaloflexa bergi (Von Graff, 1899) and C. araucariana Carbayo \& LealZanchet 2003 . This group is supported by apomorphic characters: presence of glandular formations in the head (character 10); unique specializations of the ventral cutaneous musculature in the anterior region of the body, the cephalic retractor muscle (character 25). Two well supported sub-groups are found within this clade, one composed of the Choeradoplana iheringi, Cephaloflexa bergi, C. araucariana and Notogynaphallia nataliae, and the other composed of Issoca rezendei, Supramontana irritata and Notogynaphallia caissara, $N$. fita and $N$. ceciliae. The species of the former clade lack a sensory border in the anterior tip of the body (character 17). Furthermore these species bear a head rolled backwards (character 8). The other clade is supported by the presence of a layer of mesenchymal musculature, the transversal sub-neural musculature (character 28).

\section{DISCUSSION}

Although our exemplar species occur in only seven out of the 55 biogeograhical provinces of Central and South America (Morrone, 2001), across which the Geoplaninae is known to occur, the newly generated taxonomic results are worthy of discussion.

\section{Diagnostic characters of the Geoplaninae}

According to Ogren and Kawakatsu (1990) the diagnosis of Geoplaninae is as follows: "Broad ciliated creeping sole covering most of ventral surface (or sparse body cilia as in the genus Geobia); mouth just behind midbody (since in Polycladus the mouth is in posterior fourth); dorsal testes; sub-epithelial or cutaneous longitudinal musculature, well developed, arranged in bundles; longitudinal parenchymal muscle absent, or not well developed, not forming a ring zone." The principal characters of this current diagnosis of the Geoplaninae given by Ogren and Kawakatsu (1990) can be scored by the following of our characters: (5), (23), (30-32), and (40). Unfortunately, none of these characters are restricted to the Geoplaninae, according to our results.

Broad creeping sole is not an apomorphy as Enterosyringa pseudorhynchodemus and Xerapoa hystrix have thin creeping soles that are about one-third to half of the body width 
(character 5).

A strong bundle-packed cutaneous musculature (23) is a symplesiomorphic state of character for Geoplaninae, as it is also present in the non-Geoplaninae species Dolichoplana carvalhoi and Endeavouria septemlineata in our tree, as well as other taxa such as the genera Platydemus and Cotyloplana (Graff, 1899). Furthermore, the cutaneous musculature of Enterosyringa pseudorhynchodemus and Xerapoa hystrix is very weak, although it is packed in small bundles. This reduction in musculature may be the result of secondary loss in small species.

Longitudinal mesenchymal musculature absent or weak (characters 30-32) cannot represent an autapomorphy for the Geoplaninae as bundles of mesenchymal longitudinal musculature are present in Notogynaphallia guaiana and N. goetschi. In Pelmatoplanini and Microplaninae the mesenchymal longitudinal muscles form a ring-zone that encircles the body organs. In the Caenoplanini and Bipaliini the longitudinal mesenchymal muscle fibers form a longitudinal ventral plate. In Geoplaninae the longitudinal ventral plate and the lonitudinal ring zone are absent, but in Notogynaphallia guaiana and N. goetschi the mesenchymal longitudinal fibers gather in bundles above and below the intestine.

The dorsal location of the testes (character 40) was a character exclusive to the Geoplaninae until Winsor $(2006,2009)$ described dorsal testes for the Anzoplanini and Eudoxiapoplanini. The description of the Anzoplanini and the Eudoxiatopoplanini, with ventral and dorsal testes simultaneously and dorsal testes respectively, removed the exclusiveness of this character.

Perhaps one character may form an autapomorphy for the Geoplaninae, viz the absence of a glandular canal (character 58). In Caenoplanini, Eudoxiatopoplanini, and Anzoplanini the shell glands open into a special compartment of the female atrium, the glandular canal, which bears an epithelium different from that of the female atrium and the oviducts. Although this may not be the case for all Geoplanidae, it is at least absent in all Geoplaninae species studied herein. In this subfamily the shell glands either open into the terminal portion of the oviducts, or into a blended extension of these ducts, the common glandular duct, and in most cases both the oviducts and the common glandular duct receive the opening of shell glands. Thus in the Geoplaninae the shell glands always open into the terminal portion of the oviducts, or into the common glandular duct. 


\section{Enterosyringa and Xerapoa}

Enterosyringa pseudorhynchodemus plus Xerapoa hystrix form a clade that is the sistergroup of all other geoplaninid species in our tree. They are are rather small cylindroid species with a narrow creeping sole. This result contradicts Graff's theory. Graff (1899, p. 248) suggested that the most basal Geoplaninae species would be flat species with wide creeping soles; according to Graff the broad bodied Geoplaninae are the most primitive group of land planarians.

Our results are close to Meixner's (1928) perspective. Meixner considered the Microplaninae as basal geoplaninids, and under this perspective the basal position of Pelmatoplanini and Enterosyringa pseudorhynchodemus and Xerapoa hystrix within Geoplaninae is supported, as these taxa share a rounded body and a thin creeping sole similar to the body-plan of the Microplaninae.

E. pseudorhynchodemus and $X$. hystrix represent an intermediate state between the cylindroid and the broad flat planarians. Pelmatoplana moluccana (Pelmatoplanini) and the subfamily Microplaninae are characterized by having a cylindroid body, thin creeping sole and a nervous system arranged in two longitudinal chords (Figure 2D). These characters are present in the clade E. pseudorhynchodemus $+X$. hystrix, and absent in all other Geoplaninae studied herein. Nonetheless, several morphological characters confirm the position of $E$. pseudorhynchodemus and $X$. hystrix within the Geoplaninae: cutaneous musculature packed in bundles; absence of mesenchymal longitudinal musculature external to nervous chords; testes located dorsally; testes extending from anterior region to pharyngeal region; shell glands opening into a common glandular duct.

\section{Monophyly of the genera}

The present genera Notogynaphallia and Geoplana appear to be non-natural groups in our study. The heterogeneous nature of Notogynaphallia was already pointed out by LealZanchet \& E. M. Froehlich $(2001,2006)$ and Carbayo (2006), although this has not yet resulted in any taxonomic formalization, except for a new genus formed by some species split off from Notogynaphallia (Carbayo, 2010).

The monophyletic clade composed of Notogynaphallia octostriata, N. mourei and N. plumbea. The type species of the genus, N. plumbea, is not easily characterized by an autapomorphy. The absence of a penis papilla can no longer serve as a diagnostic character 
as it is homoplasic. Perhaps, a more consistent character, although not exclusive, is the absence of an ejaculatory duct (character 50 )(Figure 2B).

\section{New clades within Geoplaninae}

The synapomorphies (a glandular body ridge and bifurcated prostatic vesicle) for the Andean clade are not exclusive to this clade, and thus are weakly supporting their relationships. However, a unique feature is observed within this clade, the ultra-dorsal position of the testes. In most of the Geoplaninae the testes are located underneath the transversal supra-intestinal layer, whereas in the Colombian species Notogynaphallia andina and Amaga amagensis, the testes are located above the supra-intestinal transversal mesenchymal layer (character 41). These ultra-dorsal testes are also known from two Peruvian species viz. Geoplana lama du Bois-Reymond Marcus, 1951, and G. cantuta du Bois-Reymond Marcus, 1951 (FC, pers. obs.). They are also present in Polycladus gayi (JHG, pers. obs.), a broad species native to southern central Chile, and thus supports the position of this taxon within the Andean clade.

The close relationship of Geoplana tuxaua and Geoplana matuta has been pointed out already by E.M. Froehlich (1955). Both species are morphologically distant from the type species of the genus, Geoplana vaginuloides. This species is characterized by having a penis papilla provided with layers of muscular bundles that completely occupies the male and female atrium, and the absence of a prostatic vesicle. In contrast, G. tuxaua and G. matuta have a penis papilla with weak musculature that is not packed in bundles. They also possess a prostatic vesicle and instead of having an ejaculatory duct, they have an ejaculatory cavity. Furthermore, G. tuxaua and G. matuta also have a pluristratified epithelium in the female atrium.

The sistergroup relationship between Notogynaphallia guaiana and $N$. goetschi is strongly supported in our analysis. An synapomorphic feature shared by them is the presence of bundles of mesenchymal longitudinal fibres located between the central nervous system and the intestinal branches. In N. guaiana and N. goetschi these bundles are found as separate dorsal and ventral layers and as a continuous tube-like arrangement, respectively. While the longitudinal mesenchymal musculature is present in many species of Geoplaninae, Pelmatoplanini, Caenoplanini, they are seemingly non homologous as in the two species they are located internally to the central nervous system, whereas in Pelmatoplanini and 
Caenoplanini this musculature is external the central nervous system.

The presence of a cephalic retractor muscle constitutes a synapomorphy for species with cephalic specializations. Generally the ventral cutaneous musculature gradually weakens towards the anterior part of the body. However, in the following species the ventral cutaneous musculature strengthens to form a cephalic retractor muscle: Notogynaphallia caissara, $N$. fita, N. ceciliae, N. nataliae, Issoca rezendei, Choeradoplana iheringi, Supramontana irritata, Cephaloflexa bergi and $C$. araucariana. The clade is also supported by the presence of glandular accumulations and a transversal sub-nerual mesenchymal muscle layer in the cephalic region.

The structure of the cephalic retractor muscle varies between clusters of genera. In Cephaloflexa and Choeradoplana the muscle bundles are parallel to the antero-posterior body axis, whereas in Supramontanta, Issoca, Notogynaphallia caissara, N. fita, and $N$. ceciliae the muscle bundles open-up in a hand fashion towards the margins of the cephalic region. Until further evidence is gathered, the different arrangement of the fibres of the cephalic retractor in these geoplaninids should not be explained by parallelism.

\section{Species of uncertain phylogenetic position}

The phylogenetic position of Liana guasa (Geoplaninae), not considered in our phylogenetic analysis, constitutes a difficult taxonomic problem as it has been described on the basis of immature animals in which the gonopore has still not opened, and therefore not all relevant characters can be inferred from the copulatory apparatus (E.M. Froehlich, 1978). It seems to belong to Geoplaninae since the immature testes are placed dorsally and with the same extension along the body as the other Geoplaninae. The cutaneous musculature is similar to that found in Gusana cruciata, with which it is sympatric. In Liana guasa both dorsal and ventral musculature are insunk into the mesenchym, the ventral cutaneous musculature is totally insunk and reaches up to the central nervous system, forming a flat dense aggregation of muscle fibers. These characteristics are exclusive to Gusana cruciata and a few other undescribed Geoplaninid taxa from southern Chile (JHG. pers. obs.). Therefore, until further evidence is gathered we conclude that Liana might be related with Gusana.

\section{CONCLUSIONS}

The phylogenetic relationships resulting from this study represent the first evolutionary hypothesis for the morphologically diverse Geoplaninae. These results are merely a starting 
point and should hopefully form the basis for future studies.

The present study supports the monophyly of the Geoplaninae but the current taxonomic concept for the various genera is unsatisfactory. For example, the genera Geoplana and Notogynaphallia are most likely to be a polyphyletic assemblage of species.

Some of the morphological characteristics mentioned in current generic diagnoses are inconsistent with our phylogenetic analysis. The presence of penis papilla should no longer remain as a diagnostic character without a definition for the different penial apparatuses found across the Geoplaninae. The absence of penis papilla was found to be homoplastic. Thus, the generic diagnoses of the genera comprising Geoplaninae need to be re-evaluated.

Future approaches would greatly benefit from larger taxon sampling and from molecular characters. Including species from other unexplored biogeograhical provinces would also help to identify more subgeneric groups and to understand their morphological evolution. Ultrastructural morphological characters would also most certainly prove useful, since the study of the morphology of planarians through histology may be limited. Further attention should be paid to the ultrastructure of the pluristratified epithelium of the female atrium in some planarians.

\section{REFERENCES}

Álvarez-Presas, M.; Baguñà J, \& Riutort M. 2008. Molecular phylogeny of land and freshwater planarians (Tricladida, Platyhelminthes): from freshwater to land and back. Molecular Phylogenetics and Evolultion, 47:555-568.

Carbayo, F. 2003. Revisión de Notogynaphallia Ogren \& Kawakatsu, 1990 (Platyhelminthes, Tricladida) . PhD thesis. Universidad de Salamanca, Salamanca.

Carbayo, F. 2010. A new genus for seven Brazilian land planarian species, split off from Notogynaphallia (Platyhelminthes, Tricladida). Belgian Journal of Zoology. In print.

Carbayo, F.; Leal-Zanchet, A.M. \& Vieira, E.M. 2002. Terrestrial flatworm (Platyhelminthes: Tricladida: Terricola) diversity vs. man-induced disturbance in a subtropical rainforest from Southern Brazil. Biodiversity and Conservation, 11: 1091-1104.

Carbayo, F. \& Leal-Zanchet, A.M. 2003. Two new genera of Geoplaninae (Terricola:

Tricladida: Platyhelminthes) of Brazil in the light of cephalic specializations. 
Invertebrate Systematics, 17 (3): 449-468.

Carranza, S.; Ruiz-Trillo, I.; Littlewood, D.T.J.; Riutort, M. \& Baguñà, J. 1998. A reappraisal of the phylogenetic and taxonomic position of land planarians (Platyhelminthes, Turbellaria, Tricladida) inferred from 18S rDNA sequences. Pedobiologia, 42: 433-440.

Dallwitz, M. J. 1980. A general system for coding taxonomic descriptions. Taxon, 29: 41-6.

Dallwitz, M. J.; Paine, T. A. \& Zurcher, E. J. 1999 onwards. User's guide to the DELTA Editor. http://delta-intkey.com

Goloboff, P. A.; S. Farris, \& K. C. Nixon. 2008. TNT: tree analysis using new technology. Program and documentation, available from the authors, and at www.zmuc.dk/public/phylogeny.

Froehlich, E.M. 1955. Sobre espécies brasileiras do gênero Geoplana. Boletim da Faculdade de Filosofia, Ciências e Letras da Universidade de São Paulo, série Zoologia, 19: 289-369.

Froehlich, E.M. 1955. Sobre espécies brasileiras do gênero Geoplana. Boletim da Faculdade de Filosofia, Ciências e Letras da Universidade de São Paulo, série Zoologia, 19: 289-369.

Hallez P. 1892. Catalogue des Turbellariés (Rhabdocoelides, Triclades et Dendrocoelides) du Nord de la France \& de la Cote Boulonnaise. Revue Biologique du Nord de la France. 4:301-326; 338-350; 425-456.

Hyman, L. H. 1951. The Invertebrates: Platyhelminthes \& Rhynchocoela. Vol. 2. McGraw Hill: N.Y., USA. 550 pp.

Kawaguti, S. 1932. On the physiology of land planarians. Memoirs of the Faculty of Science and Agriculture, Taihoku Imperial University 7:15-55

Leal-Zanchet, A.M. \& Froehlich, E. M. 2001. A species complex in the genus Notogynaphallia (Tricladida: Terricola). Belgian Journal of Zoology, 131 (supl): 225226.

Leal-Zanchet, A.M. \& Froehlich, E.M. 2006. A species complex in the genus Notogynaphallia Ogren and Kawakatsu (Platyhelminthes: Tricladida: Terricola) with a taxonomic revision of homonyms of Geoplana marginata Schultze \& Mueller and a reinterpretation of Notogynaphallia caissara (Froehlich) anatomy. Belgian Journal of Zoology. 136(1):81-100.

Morrone J.J. 2001. Biogeografia de America Latina y el Caribe. M \& T-Manuales y Tesis 
SEA, vol. 3, Sociedad Entomologica Aragonesa, Zaragoza.

Meixner, J. 1928. Der Genitalapparat der Tricladen und seine Beziehungen zu ihrer allgemeinen Morphologie, Phylogenie, Okologie und Verbreitung. Zeitschrift für Morphologie und Ökologie der Tiere. 11 (5): 570-612.

Ogren, R.E. 1995. Predation behaviour of land planarians. Hydrobiologia, 305: 105-111.

Ogren, R.E. \& Kawakatsu, M. 1990. Index to the species of the family Geoplanidae (Turbellaria, Tricladida, Terricola) Part I: Geoplaninae. Bulletin Fuji Women's College 28 (I): 79-166.

Sereno, P. C. 2007. Logical basis for morphological characters in phylogenetics. Cladistics 23:565-587.

Sluys, R. 1999. Global diversity of land planarians (Platyhelminthes, Tricladida, Terricola): a new indicator-taxon in biodiversity and conservation studies. Biodiversity and Conservation 8:1663-1681.

Sluys, R.; Kawakatsu, M.; Riutort, M. \& Baguñà, J. 2009. A new higher classification of planarian flatworms (Platyhelminthes, Tricladida). Journal of Natural History, 43:29,1763-1777.

Von Graff, L. 1899. Monographie der Turbellarien: II. Tricladida Terricola (Landplanarien). Engelmann, Leipzig.

Winsor, L. 2006. New and revised terrestrial flatworm taxa (Platyhelminthes: Tricladida: Terricola) of Australia and the Subantarctic Islands of New Zealand. Tuhinga, 17: 81104.

Winsor, L. 2009. A new subfamily, new genus and new specie of terrestrial flatworm (Platyhelminthes:Tricladida: Geoplanidae) from Stewart Island, New Zealand. Tuhinga, 20: 23-32. 
Apendix 1. Selected morphological characters for the phylogeny of the Geoplaninae.

1. Body, Shape. (1) lanceolate, less than 10:1. (2) sublineal, between 10:1 - 20:1. (3) lineal, over 20:1

2. Body, Shape of anterior end. (1) rounded. (2) tapered. (3) spatulate. (4) semilunate

3. Body, Shape of posterior end. (1) rounded. (2) tapered. (3) caudal Tip. (4) pointed

4. Body, Transversal shape. (1) rounded 1:1. (2) median1:2. (3) Flattened1:(>2)

5. Body, creeping sole width. (1) thin, less than $40 \%$. (2) median, between 40 and $60 \%$. (3) wide, over $60 \%$

6. Body, presence of glandular keel. (1) absent. (2) present

7. Body, presence of glandular ridge. (1) absent. (2) present

8. Head, rolled backwards. (1) absent. (2) present

9. Head, rhabdoids placed over transversal subneural mesenchymal muscle layer. (1) absent. (2) present

10. Head, presence of glandular formations. (1) absent. (2) present

11. Head, sensory papillae. (1) absent. (2) present

12. Eyes, number. (1) two. (2) multiple. (3) zero

13. Eyes, dorsal. (1) absent. (2) present

14. Eyes, extending. (1) only in anterior region. (2) midbody. (3) whole body

15. Eyes, cup. (1) unicelular. (2) multicelular

16. Eyes, present in anterior tip in multiple rows. (1) absent. (2) present

17. Sensory Zone, distribution. (1) Absent from anterior tip. (2) Around anterior tip

18. Sensory pits, invagination type. (1) Simple invaginations. (2) Branched invaginations

19. Sensory pits, number of rows. (1) Single row. (2) Multiple row

20. Sensory pits, distribution. (1) Restricted to sensorial fends. (2) Distributed freely

21. Sensorial fends, presence. (1) absent. (2) present

22. Cutaneous musculature, number of muscle layers. (1) Three (circular, double diagonal and inner longitudinal). (2) Two (circulo-helicoidal and an inner longitudinal)

23. Cutaneous musculature, longitudinal fibers arranged. (1) Separately. (2) Packed in bundles

24. Cutaneous musculature, longitudinal immersion into mesenchym. (1) not insunk. (2) only ventrally insunk. (3) dorsally and ventrally insunk

25. Cutaneous musculature, cephalic retractor muscle. (1) absent. (2) present

26. Mesenchymal musculature, dorsal double diagonal. (1) absent. (2) present

27. Mesenchymal musculature, transversal sub-neural in pre-pharyngeal region. (1) absent. present

28. Mesenchymal musculature, transversal sub-neural in cephalic region. (1) absent. (2) 
present

29. Mesenchymal musculature, supra intestinal layer in crisscross disposition. (1) absent. (2) present

30. Mesenchymal musculature, longitudinal fibers internal to nerve plate, packed in bundles. absent. (2) present

31. Mesenchymal musculature, longitudinal fibers internal to nerve plate. (1) absent. (2) present

32. Mesenchymal musculature, longitudinal ventral plate. (1) absent. (2) present

33. Mesenchymal musculature, longitudinal tube. (1) absent. (2) present

34. Pharynx, external muscle orientation. (1) (epithelium) - Longitudinal - Circular. (2) (epithelium) Circular - Longitudinal. (3) (epithelium) - Longitudinal circular longitudinal

35. Pharynx, external muscle arrangement. (1) not intermixed. (2) intermixed

36. Pharynx, external muscle forming separate layers. (1) absent. (2) present

37. Pharynx, internal muscle orientation. (1) (epithelium) - circular - congitudinal. (2) (epithelium)longitudinal - circular. (3) (epithelium)- longitudinal - circular - longitudinal

38. Pharynx, internal muscle arrangement. (1) not intermixed. (2) intermixed

39. Pharynx, internal muscle arrangement forming layers. (1) absent. (2) present

40. Testes, dorso ventral extent. (1) ventral. (2) dorsal

41. Testes, situated above supra-intestinal Mesenchymal muscle layer. (1) absent. (2) present

42. Testes, presence in pre-pharyngeal region. (1) absent. (2) present

43. Testes, presence between ph. and ca.. (1) absent. (2) present

44. Testes, presence posterior to ca.. (1) absent. (2) present

45. Vas Deferens, position relative to nerve chords. (1) ventral. (2) dorsal

46. Vas Deferens, approach to copulatory organs. (1) separately. (2) united

47. Seminal Vesicle, location regarding common muscular coat. (1) external. (2) internal

48. Seminal Vesicle, intra-bulbar. (1) absent. (2) present

49. Seminal vesicle, bifurcated. (1) absent. (2) present

50. Ejaculatory duct, presence. (1) absent. (2) present

51. Male atrium, protrusible penis. (1) absent. (2) present

52. Male atrium, eversible penis. (1) absent. (2) present

53. Male atrium, inverted penis. (1) absent. (2) present

54. Male atrium, permanent penis. (1) absent. (2) present

55. Male atrium, musculature associated. (1) circular longitudinal. (2) circular intermixed with longitudinal. (3) circular

56. Penis papilla, degree of musculature development. (1) independent musculature. (2) same as 
atrial musculature

57. Penis papilla, glandular ridges. (1) absent. (2) present

58. Female atrium, glandular canal. (1) absent. (2) present

59. Female atrium, epithelium type. (1) columnar. (2) pseudostratified lacunar. (3) pluristratefied

60. Vagina, antero-posterior position. (1) Posterior end. (2) Posterior, but not end. (3) Anteriorly

61. Vagina, dorso-ventral position. (1) ventral. (2) medial. (3) dorsal

62. Vagina, bending. (1) anteriorwards. (2) posteriorwards

63. Ovaries, ovaries placed over transversal sub-intestinal. (1) absent. (2) present

64. Ovaries, presence of tubae. (1) absent. (2) present

65. Ovaries, placed posterior to anterior-most testes. (1) absent. (2) present

66. Oviducts, connection to atrium. (1) forming common oviduct. (2) connecting at the same time. (3) connecting separately

67. Oviducts, fusing into long common glandular duct. (1) absent. (2) present

68. Nervous system, type. (1) flat plate. (2) two chords

69. Musculo-glandular organs, presence. (1) absent. (2) present 
Figure 1. A 50\% majority rule consensus tree. Group frequencies indicated at each node. Main synapomorphies indicated in black sqaure boxes.

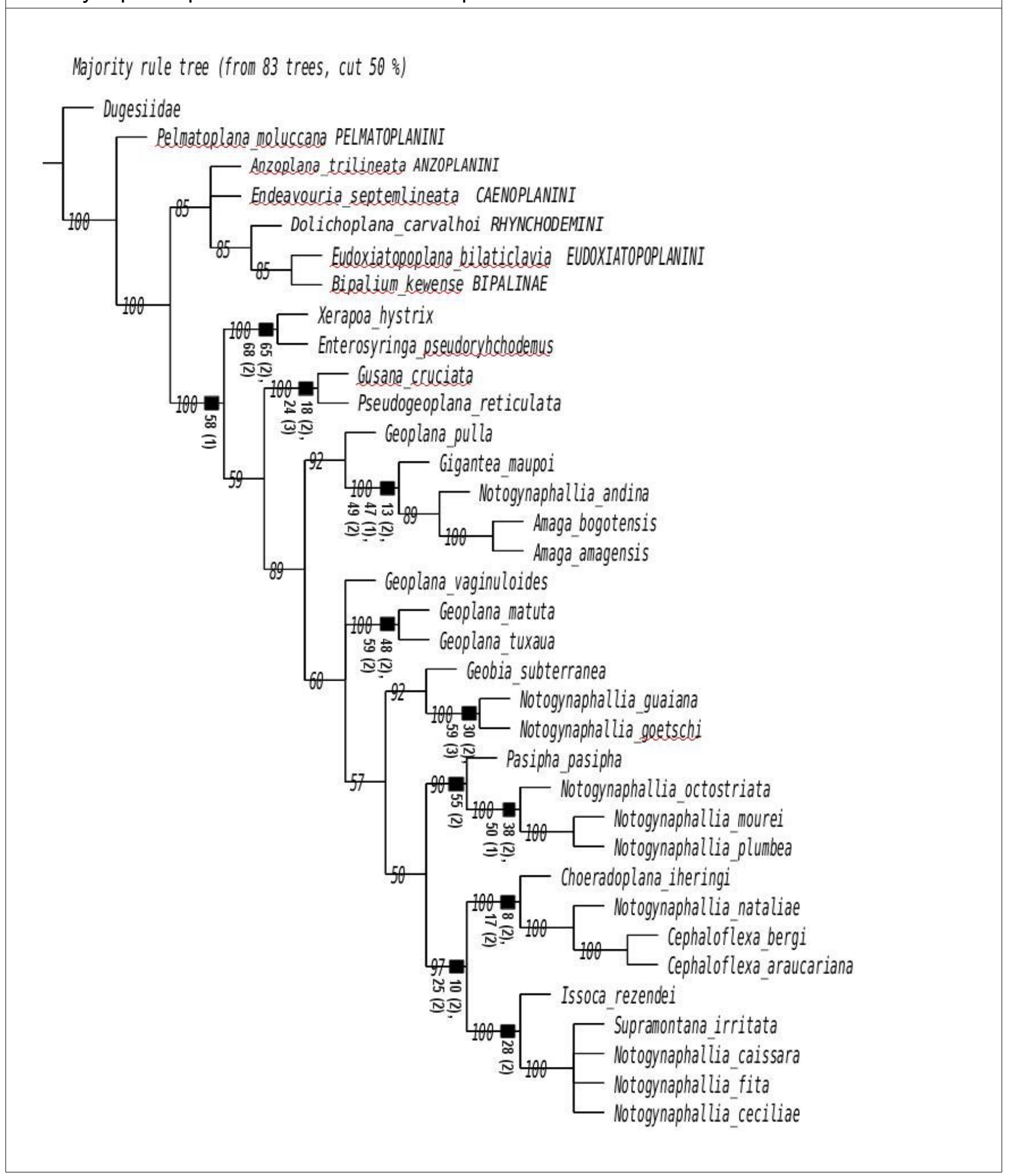


Figure 2. Character state trees of characters $38,50,54$ and 58.

A Character 38. Pharynx,_internal_muscle_arrangment

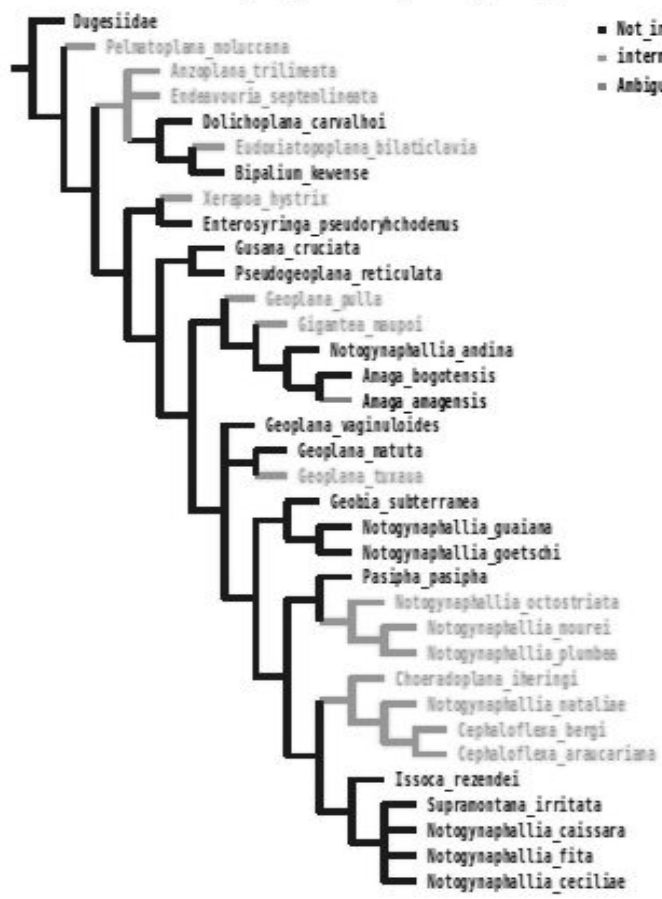

C

Character 54. Male_atrium,_permanent_penis

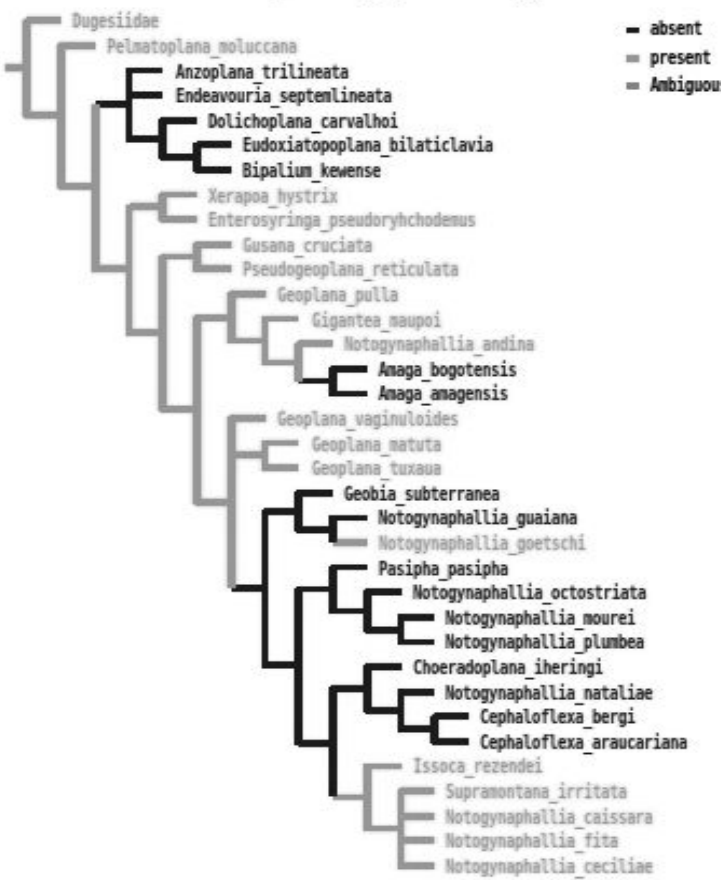

B

Character 50. Ejaculatory_duct,_presence

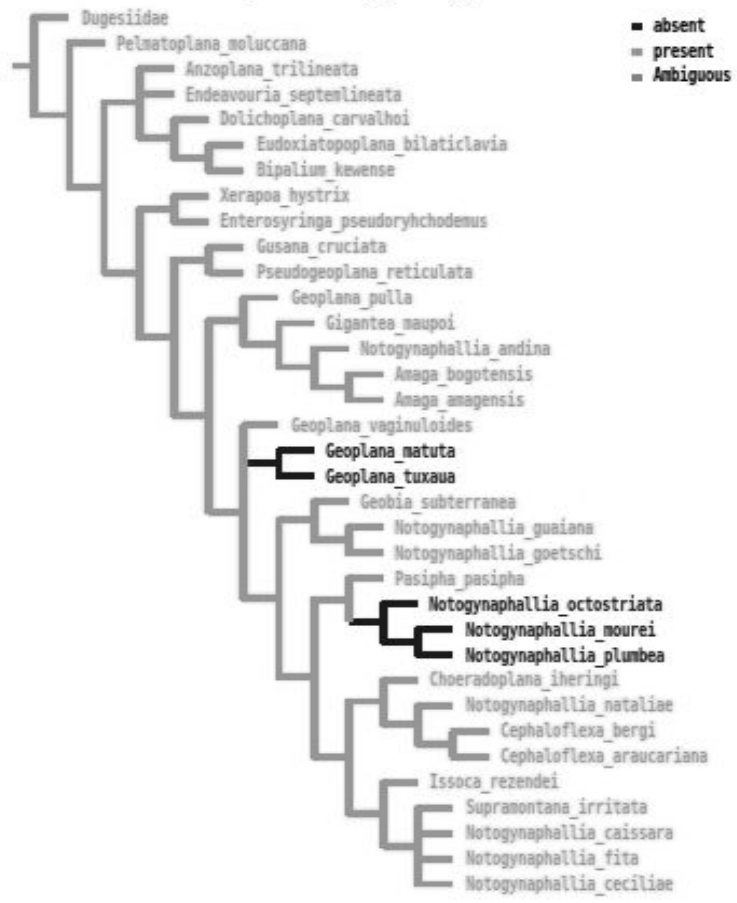

D Character 68. Nervous_system,_type

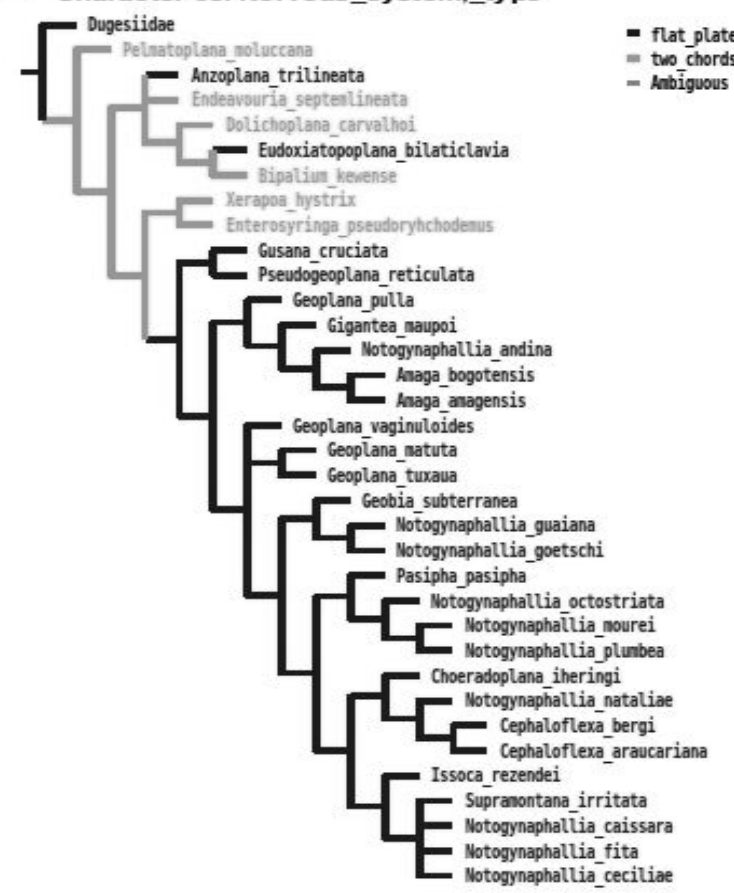


Table 1.1 Data matrix for the phylogenetic analysis of the Geoplaninae (to be continued)

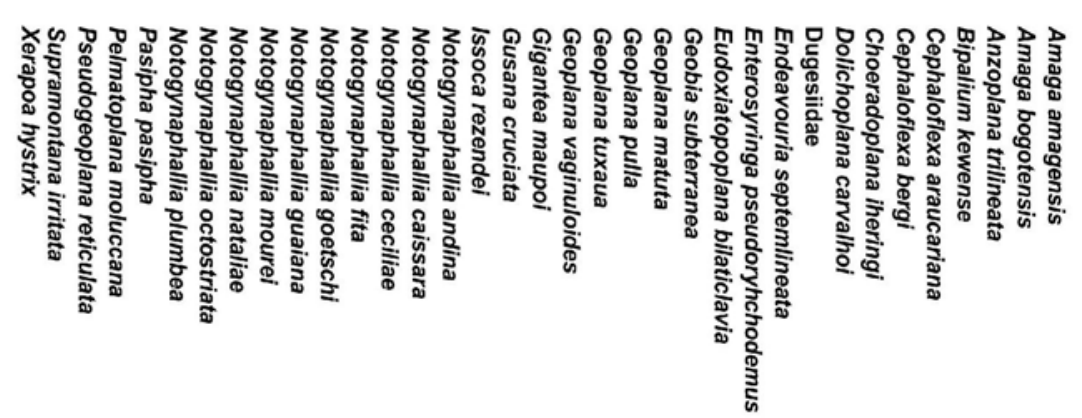

$\omega N N N N N N N N \rightarrow-\omega N N N N N N N N \rightarrow \omega \omega \rightarrow \omega N \rightarrow \omega N N N \omega N \rightarrow-1$ Body, Shape

$N \rightarrow N N N N N \rightarrow N N N N N N N \omega N N N N N N \rightarrow \rightarrow N \rightarrow \rightarrow \rightarrow N N N \rightarrow N N N 2$ Body, Shape of anterior end

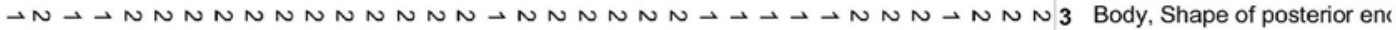
$\rightarrow \omega \omega \rightarrow \omega N N \omega N \omega \omega \omega \omega \omega \omega \omega \omega \omega \omega \omega \omega \omega \omega N \rightarrow \omega \omega N N \omega \omega \rightarrow \omega \omega \omega 4$ Body, Transversal shape $N \omega \omega \rightarrow \omega \omega \omega \omega \omega \omega \omega \omega \omega \omega \omega \omega \omega \omega \omega \omega \omega \omega \sim \sim N N \omega N \omega \omega \omega \rightarrow \omega \omega \omega 5$ Body, creeping sole width

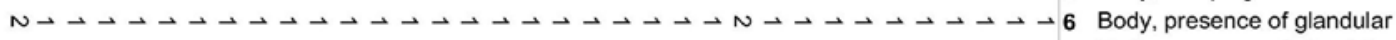

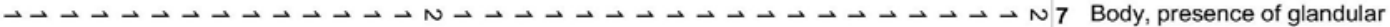

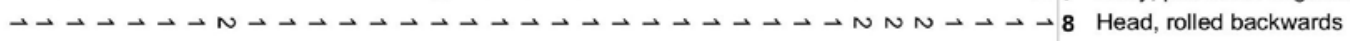

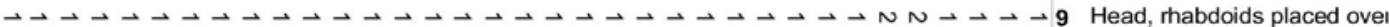
$\rightarrow N \rightarrow \rightarrow \rightarrow \rightarrow+N \rightarrow \rightarrow-N N N \rightarrow N \rightarrow \rightarrow-\rightarrow \rightarrow-\rightarrow \rightarrow-\rightarrow \rightarrow-N N N \rightarrow \rightarrow \rightarrow-10$ Head, presence of glandular

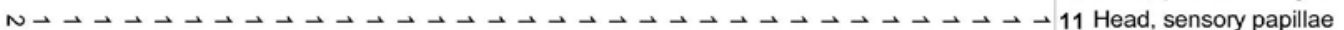

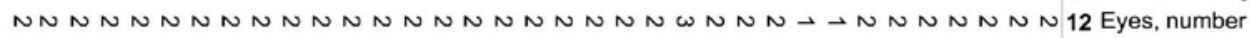

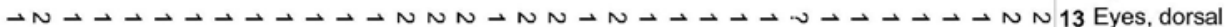
$N \omega \rightarrow \rightarrow \omega \omega \omega \omega \omega \omega \omega \omega \omega \omega N \omega \rightarrow \omega \omega \omega \omega \omega \cdot \omega N \omega \rightarrow \rightarrow \omega \omega \omega \rightarrow \rightarrow N N 14$ Eyes, extending

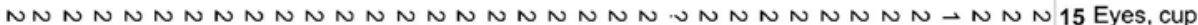
$\rightarrow \rightarrow \rightarrow \rightarrow \rightarrow-\rightarrow \rightarrow-\rightarrow \rightarrow-\rightarrow \rightarrow-\rightarrow \rightarrow-\rightarrow \rightarrow-\rightarrow \rightarrow N \rightarrow \rightarrow-\rightarrow \rightarrow-\rightarrow N \rightarrow \rightarrow-16$ Eyes, present in anterior tip

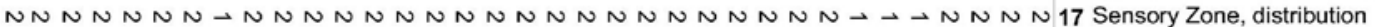
$\rightarrow \rightarrow N \rightarrow \rightarrow-\rightarrow \rightarrow-\rightarrow \rightarrow-\rightarrow \rightarrow-\rightarrow N \rightarrow-\rightarrow-\rightarrow \rightarrow-\rightarrow \rightarrow-\rightarrow \rightarrow-\rightarrow-\rightarrow \rightarrow-18$ Sensory pits, invagination tyl

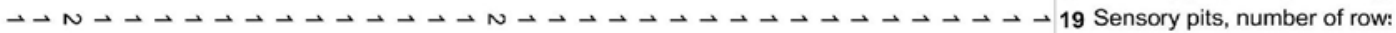

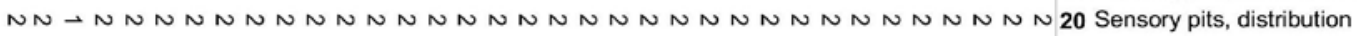

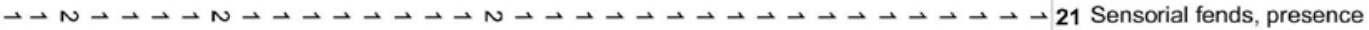
$\rightarrow \rightarrow-\rightarrow-\rightarrow-\rightarrow-\rightarrow-\rightarrow-\rightarrow-\rightarrow-\rightarrow-\rightarrow-\rightarrow-\rightarrow-\rightarrow-\rightarrow-\rightarrow-N \rightarrow-\rightarrow 22$ Cutaneous musculature, nur

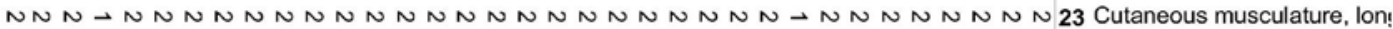

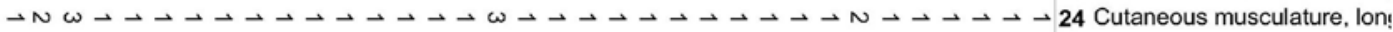
$\rightarrow N \rightarrow \rightarrow \rightarrow \rightarrow-N \rightarrow \rightarrow-N N N \rightarrow N \rightarrow \rightarrow-\rightarrow \rightarrow \rightarrow \rightarrow \rightarrow \rightarrow \rightarrow-\rightarrow N N N \rightarrow \rightarrow \rightarrow-25$ Cutaneous musculature, cep

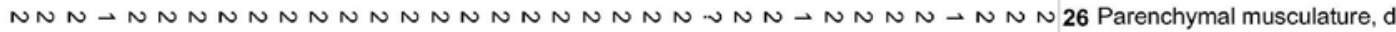

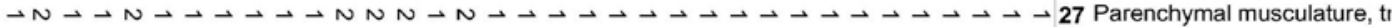
$\rightarrow N \rightarrow \rightarrow \rightarrow \rightarrow-N \rightarrow \rightarrow \rightarrow N N N \rightarrow N \rightarrow N \rightarrow \rightarrow \rightarrow \rightarrow \rightarrow \rightarrow \rightarrow \rightarrow \rightarrow-N N N \rightarrow \rightarrow \rightarrow-28$ Parenchymal musculature, ti

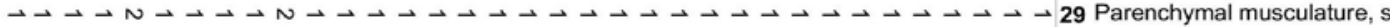
$\rightarrow \rightarrow-N \rightarrow-\rightarrow \rightarrow-N N \rightarrow-\rightarrow-\rightarrow \rightarrow-\rightarrow-\rightarrow-\rightarrow \rightarrow-\rightarrow-\rightarrow \rightarrow-\rightarrow-\rightarrow-\rightarrow 30$ Parenchymal musculature, k

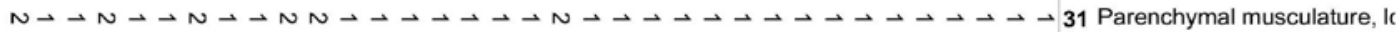
$\rightarrow \rightarrow \rightarrow \rightarrow-\rightarrow \rightarrow-\rightarrow \rightarrow-\rightarrow \rightarrow-\rightarrow \rightarrow-\rightarrow-\rightarrow \rightarrow-\rightarrow \rightarrow-N \rightarrow N \rightarrow-\rightarrow N N \rightarrow-32$ Parenchymal musculature, k

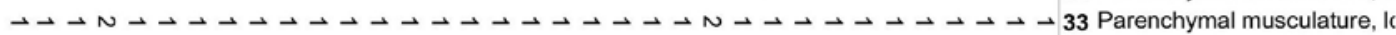
$\rightarrow \omega \omega \rightarrow \omega \rightarrow \omega \omega \omega \rightarrow \rightarrow \omega \omega \omega \rightarrow \omega \omega \rightarrow \omega \rightarrow N \rightarrow \rightarrow \omega \rightarrow \rightarrow \rightarrow \rightarrow \omega \omega \omega \sim \omega \rightarrow \rightarrow 34$ Pharynx, external muscle ori $\rightarrow N \rightarrow-N \rightarrow N N N \rightarrow-N N N \rightarrow N \rightarrow \rightarrow N \rightarrow \rightarrow \rightarrow-N \rightarrow \rightarrow \rightarrow-N N N \rightarrow \rightarrow N N 35$ Pharynx, external muscle ari $\rightarrow \rightarrow N \rightarrow \rightarrow-\rightarrow \rightarrow-\rightarrow \rightarrow-\rightarrow \rightarrow-\rightarrow N \rightarrow-\rightarrow \rightarrow-\rightarrow \rightarrow-\rightarrow \rightarrow-\rightarrow \rightarrow-\rightarrow \rightarrow-\rightarrow 36$ Pharynx, external muscle for $\rightarrow \rightarrow \rightarrow \rightarrow \rightarrow \rightarrow \rightarrow \rightarrow \rightarrow \omega \rightarrow \rightarrow \rightarrow N \rightarrow \rightarrow N \rightarrow \rightarrow N \rightarrow \rightarrow N \rightarrow \rightarrow \rightarrow N \rightarrow \rightarrow \rightarrow N N$ N $\rightarrow$ - $\rightarrow$ Pharynx, internal muscle orif $N \rightarrow \rightarrow N \rightarrow N N N N \rightarrow \rightarrow \rightarrow \rightarrow \rightarrow \rightarrow \rightarrow-N \rightarrow N N \rightarrow \rightarrow N \rightarrow N \rightarrow \rightarrow N N N \rightarrow N \rightarrow \sim 38$ Pharynx, internal muscle arri

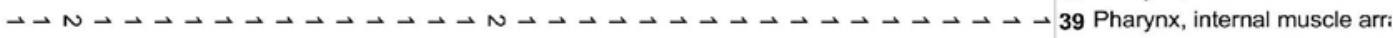
NNN $\rightarrow$ N N N N N N N N N N N N N N N N N $\rightarrow \rightarrow \rightarrow N N N \rightarrow \rightarrow N$ N 40 Testes, dorso ventral extent $\rightarrow \rightarrow-\rightarrow \rightarrow-\rightarrow-\rightarrow-\rightarrow-\rightarrow-N \rightarrow-\rightarrow-\rightarrow-\rightarrow-\rightarrow-\rightarrow-\rightarrow-\rightarrow-\rightarrow-\rightarrow$ N 41 Testes, situaded above supr

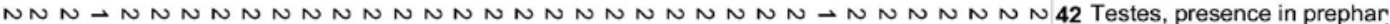
$\rightarrow \rightarrow-N \rightarrow-\rightarrow \rightarrow-\rightarrow-\rightarrow-\rightarrow-\rightarrow-\rightarrow-\rightarrow-\rightarrow-N \rightarrow N N N \rightarrow \rightarrow-\rightarrow N \rightarrow-43$ Testes, presence between $p$ $\rightarrow \rightarrow \rightarrow N \rightarrow \rightarrow \rightarrow \rightarrow \rightarrow \rightarrow \rightarrow \rightarrow \rightarrow \rightarrow \rightarrow \rightarrow \rightarrow \rightarrow \rightarrow \rightarrow \rightarrow \rightarrow N \rightarrow \rightarrow N N \rightarrow \rightarrow \rightarrow N \rightarrow \rightarrow 44$ Testes, presence posterior ts

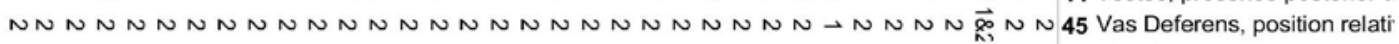

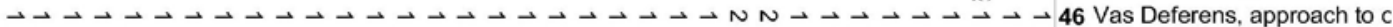
$N \rightarrow \rightarrow N \rightarrow N N N N \rightarrow \rightarrow \rightarrow \rightarrow \rightarrow \rightarrow N N \rightarrow N N N N \rightarrow N N N N N N N N N N \rightarrow \rightarrow 47$ Seminal Vesicle, location res $N \rightarrow \rightarrow N \rightarrow \rightarrow \rightarrow \rightarrow \rightarrow \rightarrow \rightarrow \rightarrow \rightarrow \rightarrow \rightarrow \rightarrow \rightarrow N \rightarrow N \rightarrow N N \rightarrow N \rightarrow \rightarrow \rightarrow \rightarrow N \rightarrow \rightarrow \rightarrow 48$ Seminal Vesicle, intra-bulbai

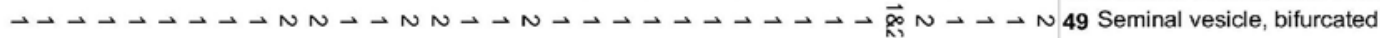

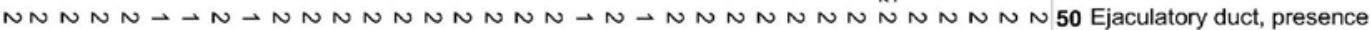

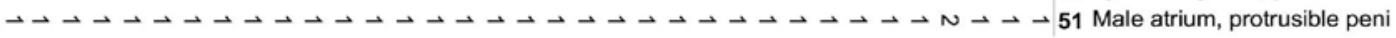


Table 1.2 Data matrix for the phylogenetic analysis of the Geoplaninae (cont.)

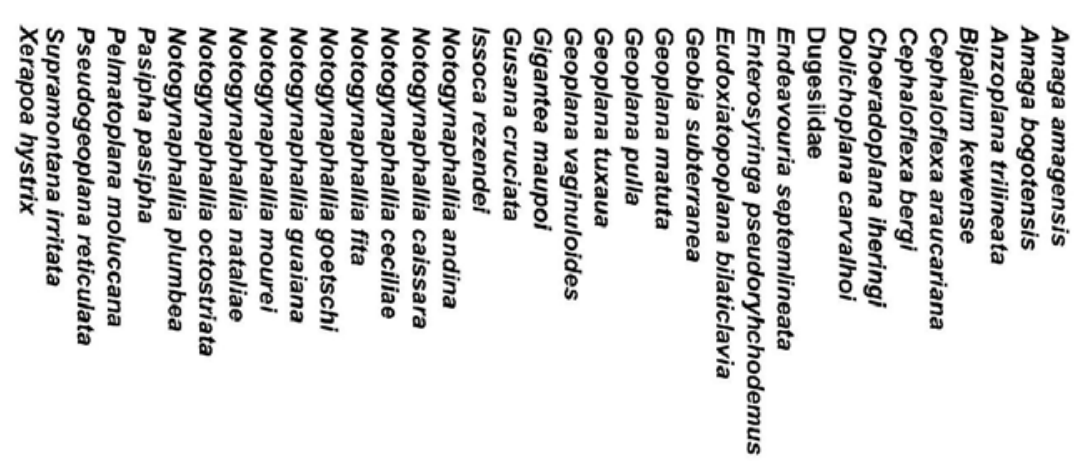

$\rightarrow+N \rightarrow N N N N N N \rightarrow \rightarrow \rightarrow \rightarrow-N N \rightarrow \rightarrow-\rightarrow-N \rightarrow \rightarrow N \rightarrow \rightarrow N N N \rightarrow N N$ N 52 Male atrium, eversible penis $\rightarrow \rightarrow \rightarrow-\rightarrow \rightarrow-\rightarrow \rightarrow-\rightarrow \rightarrow-\rightarrow-\rightarrow-\rightarrow-\rightarrow-\rightarrow \rightarrow N \rightarrow-\rightarrow \rightarrow-\rightarrow-\rightarrow \rightarrow-\rightarrow 53$ Male atrium, inverted penis $N N N N \rightarrow-\rightarrow-\rightarrow-N N N N N N N N N N N N \rightarrow-N \rightarrow N \rightarrow \rightarrow-\rightarrow \rightarrow-\rightarrow-54$ Male atrium, permanent pen

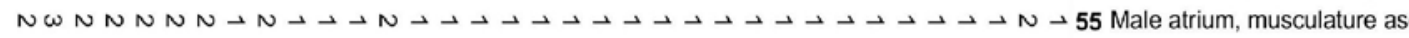

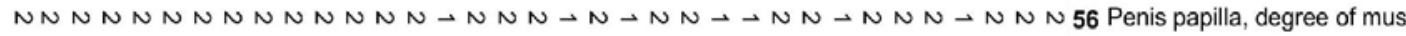

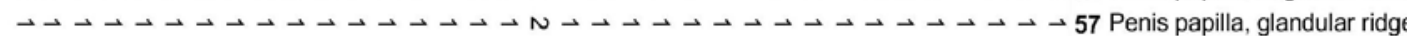
$\rightarrow \rightarrow-N \rightarrow-\rightarrow-\rightarrow-\rightarrow-\rightarrow-\rightarrow-\rightarrow-\rightarrow-\rightarrow-\rightarrow N \rightarrow N N N \rightarrow \rightarrow-N N \rightarrow-58$ Female atrium, glandular cal

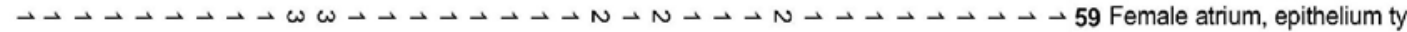
$\rightarrow \rightarrow-N \rightarrow-\rightarrow-\rightarrow-\rightarrow-\rightarrow-\rightarrow-\rightarrow-\rightarrow-\rightarrow-\rightarrow-\rightarrow-\omega N \rightarrow-\rightarrow-\rightarrow-\rightarrow 60$ Vagina, antero-posterior pos $N \omega \omega \omega-N \omega \omega N \omega \omega \omega \omega \omega \omega \omega \omega \omega \omega \omega \omega \omega \omega \omega N N N \omega \omega \omega \omega \omega-\omega \omega 61$ Vagina, dorso-ventral positic $N \rightarrow N N N \rightarrow \rightarrow-\rightarrow-\rightarrow-\rightarrow-\rightarrow-N \rightarrow-\rightarrow-\rightarrow-N N N N N \rightarrow \rightarrow-N N \rightarrow-62$ Vagina, bending

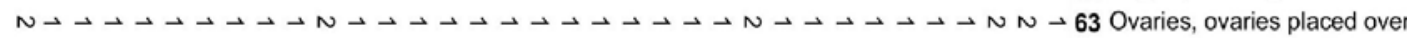

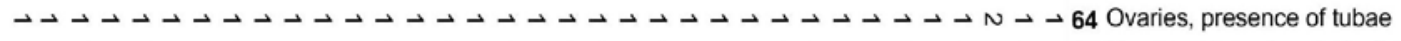

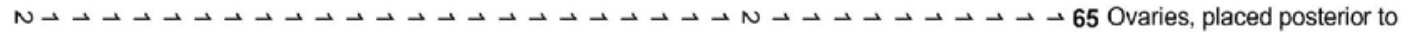
$N \rightarrow \rightarrow N \rightarrow \rightarrow \rightarrow \rightarrow \rightarrow \rightarrow \rightarrow \rightarrow-N \rightarrow \rightarrow N \rightarrow \rightarrow \rightarrow \rightarrow \rightarrow N \rightarrow \rightarrow \omega N \rightarrow \rightarrow-N N$ N 66 Oviducts, conection to atriun $\rightarrow N \rightarrow \rightarrow-\rightarrow N \rightarrow-N N N N N \rightarrow N \rightarrow-N N \rightarrow N N \rightarrow \rightarrow-\rightarrow \rightarrow N \rightarrow-\rightarrow \rightarrow-\rightarrow 67$ Oviducts, fusing into long co

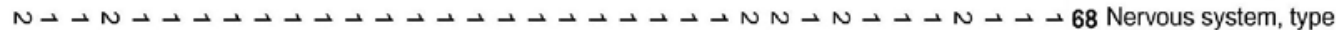

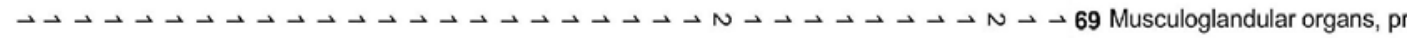

Table 2. Consistency index of the characters.

$\begin{array}{rlllllllllllll}\mathbf{1} & 0.200 & \mathbf{1 1} & 1.000 & \mathbf{2 1} & 0.500 & \mathbf{3 1} & 0.200 & \mathbf{4 1} & 0.500 & \mathbf{5 1} & 1.000 & \mathbf{6 1} & 0.333 \\ \mathbf{2} & 0.375 & \mathbf{1 2} & 0.667 & \mathbf{2 2} & 1.000 & \mathbf{3 2} & 0.500 & \mathbf{4 2} & 0.500 & \mathbf{5 2} & 0.143 & \mathbf{6 2} & 0.500 \\ \mathbf{3} & 0.500 & \mathbf{1 3} & 0.200 & \mathbf{2 3} & 1.000 & \mathbf{3 3} & 0.500 & \mathbf{4 3} & 0.500 & \mathbf{5 3} & 1.000 & \mathbf{6 3} & 0.250 \\ \mathbf{4} & 0.333 & \mathbf{1 4} & 0.400 & \mathbf{2 4} & 0.667 & \mathbf{3 4} & 0.286 & \mathbf{4 4} & 0.333 & \mathbf{5 4} & 0.200 & \mathbf{6 4} & 1.000 \\ \mathbf{5} & 0.400 & \mathbf{1 5} & 1.000 & \mathbf{2 5} & 1.000 & \mathbf{3 5} & 0.200 & \mathbf{4 5} & 1.000 & \mathbf{5 5} & 0.286 & \mathbf{6 5} & 1.000 \\ \mathbf{6} & 1.000 & \mathbf{1 6} & 1.000 & \mathbf{2 6} & 0.500 & \mathbf{3 6} & 1.000 & \mathbf{4 6} & 0.500 & \mathbf{5 6} & 0.200 & \mathbf{6 6} & 0.400 \\ \mathbf{7} & 0.500 & \mathbf{1 7} & 1.000 & \mathbf{2 7} & 0.500 & \mathbf{3 7} & 0.500 & \mathbf{4 7} & 0.200 & \mathbf{5 7} & 1.000 & \mathbf{6 7} & 0.250 \\ \mathbf{8} & 1.000 & \mathbf{1 8} & 1.000 & \mathbf{2 8} & 0.500 & \mathbf{3 8} & 0.100 & \mathbf{4 8} & 0.250 & \mathbf{5 8} & 1.000 & \mathbf{6 8} & 0.250 \\ \mathbf{9} & 1.000 & \mathbf{1 9} & 1.000 & \mathbf{2 9} & 0.500 & \mathbf{3 9} & 1.000 & \mathbf{4 9} & 0.200 & \mathbf{5 9} & 0.667 & \mathbf{6 9} & 0.500 \\ \mathbf{1 0} & 1.000 & \mathbf{2 0} & 1.000 & \mathbf{3 0} & 0.500 & \mathbf{4 0} & 0.500 & \mathbf{5 0} & 0.500 & \mathbf{6 0} & 0.667 & & \end{array}$




\section{Capítulo 4}

Considerações finais 
Neste trabalho é apresentada a caracterização de morfológica das 16 espécies-tipo da subfamília Geoplaninae e espécies pertencentes a grupos externos (Pelmatoplanini, Anzoplanini, Caenoplanini, Bipaliinae), e fornecida uma análise filogenética inferida de dados morfológicos, destas 20 espécies.

Para as descrições foram usados caracteres morfológicos supostamente informativos para filogenia propostos por Carbayo (2003) e Winsor (2003). Os caracteres levantados no estudo das espécies tipos, juntamente com caracteres encontrados em descrições na literatura, foram organizados em uma matriz para um analise filogenética. Para a analise final foram incluídas 15 especies adicionais. Um total de 35 espécies e 69 caracteres foram usadas na análise filogenética final. Com base na árvore resultante destacam-se os seguintes resultados:

a) A subfamília Geoplaninae é monofilética, tendo como sinapomorfia a posição dorsal dos testículos e uma musculatura mesenquimática fraca ou pouca desenvolvida.

b) Xerapoa hystrix e Enterosyringa pseudorhynchodemus forma um clado monofilético sustentando nas seguintes sinapomorfias: corpo cilíndrico, ovários posicionados posteriormente no corpo, sistema nervoso organizado em dois cordões longitudinais. Este clado é irmão daquele que agrupa o restante dos membros da subfamília Geoplaninae.

c) Há um clado andino composto pelas espécies Amaga amagenis, Giganea maupoi e Notogynaphallia andina, suportado pela presença de uma vesícula prostática bifurcada e de uma vesícula prostática externa ao envoltório muscular comum.

d) Notogynaphallia goetschi e N. guaiana forma um clado que sustentado pela presença de feixes de musculatura mesenquimática longitudinal no entorno ao intestino e pela existência de um o átrio feminino revestido por um epitélio pluriestratificado.

e) Há um clado, nativo da mata atlântica, composto pelas espécies Choeradoplana iheringi, Cephaloflexa bergi, C. araucariana, Issoca rezendei, Supramontana irritata, Notogynaphallia caissara, $N$. fita, $N$. nataliae e $N$. ceciliae, suportado pela presença de um músculo retrator cefálico.

Nenhum dos caracteres diagnósticos para a subfamília Geoplaninae encontrados na literatura, se mostrou autapomórfico no nosso estudo. Por outro lado, nosso estudo indica que nenhum dos representantes de Geoplaninae apresenta o canal glandular feminino (presente nas demais subfamílias). Estes possuem glândulas da casca que se abrem nos ovoviteloductos ou em uma fusão destes, chamada de ducto glandular comum. Esta 
característica é proposta como uma suposta autapomorfia do grupo.

A posição do clado formado por Xerapoa hystrix e Enterosyringa pseudorhynchodemus como grupo irmão do restante de Geoplaninae pode ser explicado com a proposta filogenética de Meixner (1928), pois estas duas espécies apresentam as seguintes estruturas que sugerem afinidade com Pelmatoplaninae e Microplaninae: corpo cilíndrico, sistema nervoso organizado em dois cordões longitudinais e sola rastejadora fina. Embora Microplaninae não esteja incluída na nossa análise, a posição de Pelmatoplana moluccana como grupo irmão das restantes planárias terrestres sugere que as planárias terrestres de corpo cilíndrico poderiam representar as formas mais primitivas.

Na nossa análise os gêneros Notogynaphallia e Geoplana aparecem como grupos não naturais. A heterogeneidade do gênero Notogynaphallia já tinha sido sugerida por LealZanchet \& E. M. Froehlich $(2001,2006)$ e corroborada por Carbayo $(2006,2010)$. A presença de papila peniana, um caráter diagnóstico de Notogynaphallia, não pode continuar como caráter diagnóstico pois é homoplásico na nossa análise. Talvez, um caráter apropriado, embora não exclusivo, para a caracteização de Notogynaphallia seja a ausência de duto ejaculador.

Conclui se deste trabalho:

a) A nossa análise suporta a monofilia de Geoplaninae, mas o conceito taxonômico para vários gêneros é insatisfatório.

b) Algumas das características morfológicas mencionadas nas diagnoses genéricas são inconsistentes com a nossa análise filogenética. A papila peniana deve ter surgido várias vezes na evolu,ão das linhagens de Geoplaninae. A ausência de papila peniana também se mostrou homoplásica.

c) Futuros estudos se beneficiarão da inclusão de mais táxons e de caracteres moleculares. Incluir espécies de regiões biogeográficas não exploradas também ajudará a identificar mais grupos subgenéricos e entender a sua evolução morfológica. Caracteres morfológicos ultra-estruturais poderão também ser muito úteis, pois o estudo da morfologia das planarias terrestres através de histologia pode estar limitada. 


\section{Referencias bibliográficas}

Carbayo, F. 2003. Revisión de Notogynaphallia Ogren \& Kawakatsu, 1990 (Platyhelminthes, Tricladida) . PhD thesis. Universidad de Salamanca, Salamanca.

Carbayo, F. 2003. Revisión de Notogynaphallia Ogren \& Kawakatsu, 1990 (Platyhelminthes, Tricladida) . PhD thesis. Universidad de Salamanca, Salamanca.

Carbayo, F. 2010. A new genus for seven Brazilian land planarian species, split off from Notogynaphallia (Platyhelminthes, Tricladida). Belgian Journal of Zoology. In print.

Leal-Zanchet, A.M. \& Froehlich, E. M. 2001. A species complex in the genus Notogynaphallia (Tricladida: Terricola). Belgian Journal of Zoology, 131 (supl): 225226.

Leal-Zanchet, A.M. \& Froehlich, E.M. 2006. A species complex in the genus Notogynaphallia Ogren and Kawakatsu (Platyhelminthes: Tricladida: Terricola) with a taxonomic revision of homonyms of Geoplana marginata Schultze \& Mueller and a reinterpretation of Notogynaphallia caissara (Froehlich) anatomy. Belgian Journal of Zoology. 136(1):81-100.

Meixner, J. 1928. Der Genitalapparat der Tricladen und seine Beziehungen zu ihrer allgemeinen Morphologie, Phylogenie, Okologie und Verbreitung. Zeitschrift für Morphologie und Ökologie der Tiere 11 (5): 570-612.

Winsor, L. 2003. Studies on the Systematics and Biogeography of terrestrial flatworms (Platyhelminthes: Tricladida: Terricola) of the Australian Region. PhD thesis. James Cook University. Queensland, Australia. 